

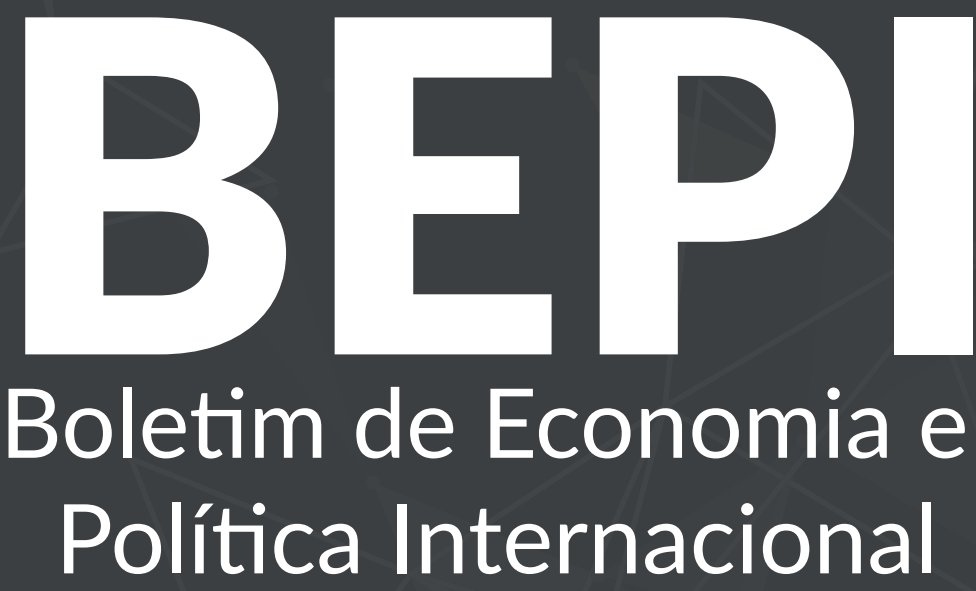

\section{Número 29}

Jan. | Abr. 2021

Conduta Empresarial Responsável e Acordos de Investimento

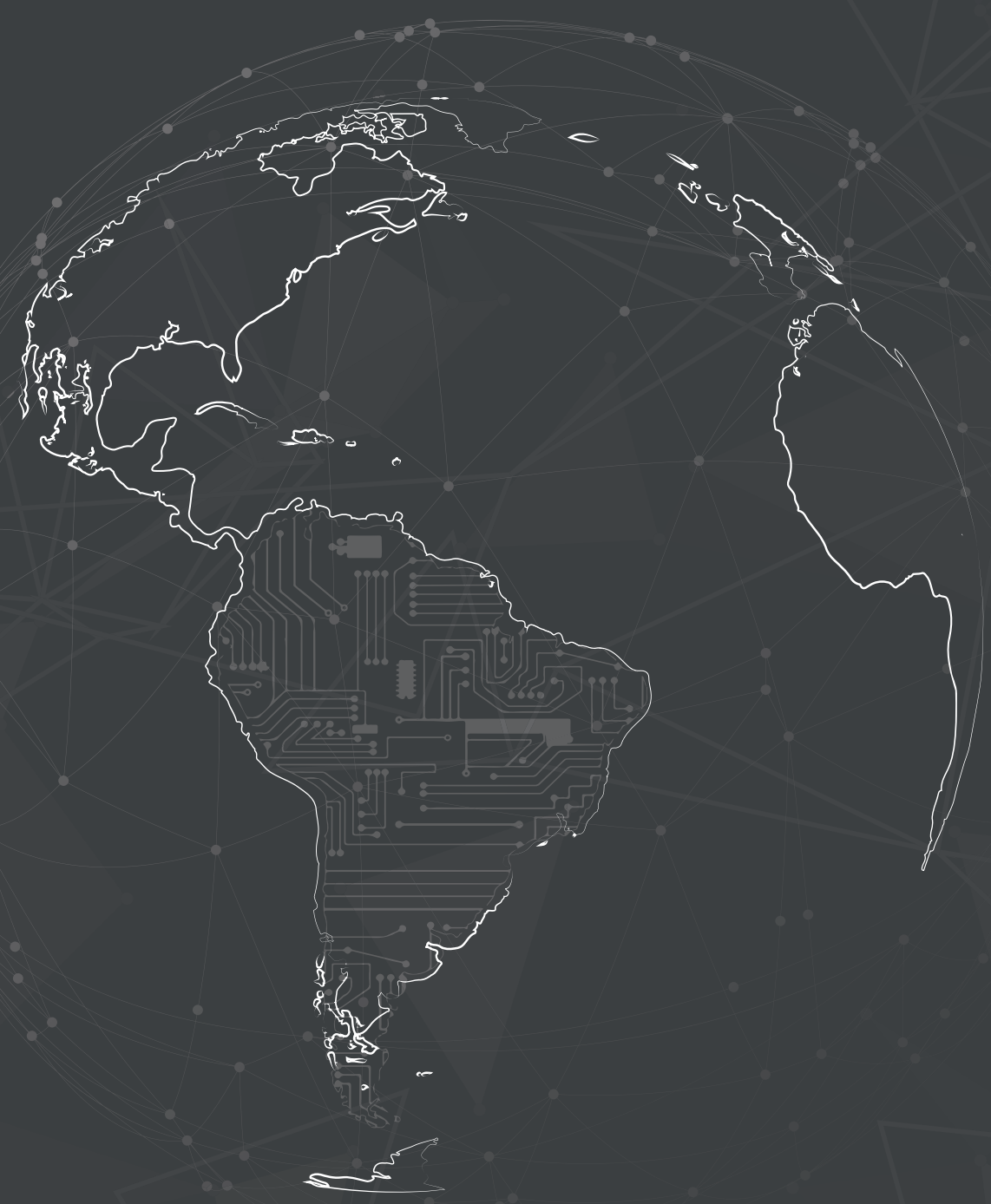


Governo Federal

Ministério da Economia
Ministro Paulo Guedes

\section{Boletim de Economia e Política Internacional}

\section{CORPO EDITORIAL}

Editor

André Gustavo de Miranda Pineli Alves

(C) Instituto de Pesquisa Econômica Aplicada - ipea 2021

Boletim de economia e política internacional/Instituto de Pesquisa Econômica Aplicada. Diretoria de Estudos e Relações Econômicas e Políticas Internacionais. - n.1, (jan./mar. 2010 - ). - Brasília: Ipea. Dinte, 2010

Quadrimestral.

ISSN 2176-9915

1. Economia Internacional. 2. Política Internacional. 3. Periódicos. I. Instituto de Pesquisa Econômica Aplicada. Diretoria de Estudos e Relações Econômicas e Políticas Internacionais.

CDD 337.05
Flávia de Holanda Schmidt

Diretor de Estudos e Políticas Macroeconômicas

José Ronaldo de Castro Souza Júnior

Diretor de Estudos e Políticas Regionais,

Urbanas e Ambientais

Nilo Luiz Saccaro Júnior

Diretor de Estudos e Políticas Setoriais de Inovação e Infraestrutura

André Tortato Rauen

Diretora de Estudos e Políticas Sociais

Lenita Maria Turchi

Diretor de Estudos e Relações Econômicas

e Políticas Internacionais

Ivan Tiago Machado Oliveira

Assessor-chefe de Imprensa e Comunicação

André Reis Diniz

Ouvidoria: http://www.ipea.gov.br/ouvidoria

URL: http://www.ipea.gov.br 


\section{SUMÁRIO}

APRESENTAÇÃo

MECANISMO DA OCDE SOBRE CONDUTA EMPRESARIAL RESPONSÁVEL:

EVIDÊNCIAS DO BRASIL E DE PAÍSES-MEMBROS DA OCDE E SUAS IMPLICAÇÕES

Edmundo Inácio Júnior

Cássio Garcia Ribeiro

IMPLEMENTACCÃO DAS DIRETRIZES DA OCDE PARA AS EMPRESAS

MULTINACIONAIS NO BRASIL: AVANÇOS E DESAFIOS

31

Hevellyn Albres

A COMUNICAÇÃO DO PCN BRASIL: COMO AS ESTRATÉGIAS E OS INSTRUMENTOS DE COMUNICAÇÃO PODEM CONTRIBUIR PARA O AUMENTO DA EFICÁCIA DA AGÊNCIA?

Luíza Mônica Assis da Silva

UMA AVALIAÇÃO DA PARTICIPAÇÃO DO BRASIL NAS DIRETRIZES DA OCDE PARA CONDUJTA RESPONSÁVEL DE EMPRESAS MULTINACIONAIS

Bernardo Mueller

Felipe Roviello

QUAIS CONTEÚDOS EMERGEM DAS INSTÂNCIAS ESPECÍFICAS RECEBIDAS

PELO PCN BRASIL? REFLEXÕES A PARTIR DE ANÁLISES LEXICAIS

Luíza Mônica Assis da Silva

TRATADOS BILATERAIS DE INVESTIMENTO: CONCEITOS, POTENCIAIS IMPACTOS E TENDÊNCIAS FUTURAS

Ignácio Tavares de Araújo Júnior

O MODELO DE ACORDO DE COOPERAÇÃO E FACILITAÇÃO DE

INVESTIMENTOS (ACFI) DO BRASIL E O REGIME INTERNACIONAL

DE INVESTIMENTOS: OS CASOS DE ANGOLA E MOÇAMBIQUE

Ana Garcia

Gabriel Torres

INVESTIMENTO EXTERNO DIRETO NA AMÉRICA LATINA:

O PAPEL DOS ACORDOS DE INVESTIMENTO

Ignácio Tavares de Araújo Júnior

ACORDOS DE INVESTIMENTO E A DIFUSÃO DAS IDEIAS DE RESPONSABILIDADE SOCIAL CORPORATIVA: APONTAMENTOS CRÍTICOS A PARTIR DO MODELO BRASILEIRO

Marina Sanches Wünsch

Fábio Costa Morosini 



\section{APRESENTAÇÃO'}

A atração de investimento direto estrangeiro (IDE), especialmente aquele voltado à ampliação e à modernização da estrutura produtiva, tem estado no centro das estratégias de desenvolvimento da maior parte dos países desde pelo menos o início dos anos 1990. Muito em voga nos anos 1960 e 1970, percepçôes negativas sobre as empresas multinacionais (EMNs), vistas como agentes do imperialismo e, por isso, uma das causas da persistência do subdesenvolvimento em grande parte do mundo, cederam lugar a visôes crescentemente positivas, com as EMNs passando a ser vistas como veículo de difusão internacional de conhecimento e de progresso técnico. Com isso, ao mesmo tempo em que modelos autárquicos de desenvolvimento, muitas vezes acompanhados de altas de doses de nacionalismo econômico e de elevada participação do Estado no papel de produtor, eram abandonados mundo afora, na esteira do esgotamento de processos de industrialização por substituição de exportaçôes, barreiras ao ingresso de estrangeiros foram levantadas e um grande conjunto de incentivos (fiscais, financeiros etc.) foram incorporados ao arsenal de guerra pela atração de IDE.

A multiplicação de tratados bilaterais de investimento (TBIs) tornou-se um dos elementos centrais dessa nova estratégia. Geralmente envolvendo um país rico, exportador de capital, e um país em desenvolvimento, desejoso de atrair investimentos, os TBIs acabaram por, na ausência de instrumento equivalente em âmbito multilateral, suprir a demanda de investidores por maior proteção de seu patrimônio em jurisdiçôes vistas como de maior risco, ao mesmo tempo em que eram percebidos pelos países em desenvolvimento como meio de impulsionar o ingresso de capitais externos.

Contudo, com o passar do tempo, tornou-se cada vez mais evidente o desbalanceamento entre direitos e obrigaçôes impostos pelos TBIs tradicionais. Enquanto EMNs podiam acionar Estados em tribunais de arbitragem internacional sempre que entendiam que seus direitos não haviam sido respeitados, o inverso não era possível. A elasticidade de interpretação de cláusulas sobre expropriação indireta inscrita em TBIs também levou à crescente desacreditação destes como mecanismos eficientes de promoção do desenvolvimento, uma vez que impunha fortes restrições à adoção de políticas públicas em áreas como saúde, meio ambiente e direitos humanos. Com isso, começaram a surgir, em diversas partes do mundo, propostas de modelos alternativos, das quais o brasileiro Acordo de Cooperação e Facilitação de Investimentos (ACFI) é um exemplo.

Esta edição especial do Boletim de Economia e Politica Internacional tem como um de seus propósitos trazer à discussão o papel exercido pelos TBIs enquanto instrumentos de promoção do IDE, buscando também compreender em que medida o ACFI pode ser entendido, ou não, como um avanço em relação ao modelo tradicional.

Assim como não existe regulação em nível multilateral acerca dos direitos dos investidores, também não há normas vinculantes a respeito da responsabilidade das EMNs sobre as consequências de sua atuação nos países em que estão presentes. O máximo que se conseguiu avançar nessa seara, em nível multilateral, são as Diretrizes sobre Conduta Empresarial Responsável da Organização para a 
Cooperação e Desenvolvimento Econômico (OCDE), que permanecem sendo um instrumento de soft law, de adoção voluntária e sem mecanismos efetivos de enforcement. A implementação das Diretrizes da OCDE no Brasil também é tema desta edição especial do Boletim, que busca, com isso, apresentar um panorama abrangente e equilibrado acerca dos instrumentos protetivos relacionados ao IDE.

No primeiro artigo, Edmundo Inácio Júnior e Cássio Garcia Ribeiro abordam as origens das Diretrizes da OCDE sobre conduta empresarial responsável, assim como sua implementação e operacionalização pelos países aderentes. Os autores também sintetizam as discussóes acadêmicas e as evidências disponíveis acerca da influência das Diretrizes sobre as agendas dos governos nacionais e sobre o comportamento das EMNs. Por fim, fazem uma análise comparativa da atuação do ponto de contato nacional $(\mathrm{PCN})$ do Brasil, órgão não judicial responsável pela resolução de disputas envolvendo EMNs e denunciantes, com a de seus congêneres em outros países aderentes às Diretrizes.

A implementação das Diretrizes da OCDE no Brasil é o tema do segundo artigo. Assinado por Hevellyn Albres, que acumula substancial experiência profissional no âmbito do PCN brasileiro, o artigo faz uma detalhada exposição das funçôes atinentes aos PCNs e avalia os avanços já alcançados no Brasil. A autora encerra o artigo elencando os desafios remanescentes e propondo algumas medidas para que o PCN brasileiro seja capaz de cumprir mais efetivamente sua missão institucional.

O uso de instrumentos de comunicação institucional pelo PCN brasileiro é o ponto central do terceiro artigo. Nele, a autora Luíza Mônica Assis da Silva advoga que uma estratégia de comunicação adequada é fundamental para que a entidade consiga contornar o maior obstáculo para o cumprimento de sua missão, que é a baixa adesão das empresas denunciadas ao mecanismo não judicial de solução de disputas. Conforme o estudo, o PCN-Brasil cumpre a maior parte dos requisitos obrigatórios em termos de comunicaçôes, mas deixa de aproveitar o potencial de diversos instrumentos, como os eventos promocionais, devido à ausência de uma estratégia integrada de comunicação e à baixa autonomia de sua equipe técnica em relação ao tema.

As Diretrizes da OCDE são efetivamente capazes de influenciar o padrão de comportamento das EMNs? É essa questão que Bernardo Mueller e Felipe Roviello buscam responder no quarto artigo. Nele, os autores partem do princípio de que a efetividade das Diretrizes depende crucialmente de sua capacidade de impor custos reputacionais às empresas, uma vez que a participação destas no programa de mediação de disputas é voluntária. Dependendo da visibilidade alcançada por uma denúncia, consumidores podem, entre outras coisas, decidir boicotar os produtos da empresa, com impactos sobre receitas e lucros, o que, em última instância, tende a impactar o valor de suas açóes. Para averiguar se uma denúncia ao PCN brasileiro afeta o preço das açôes, os autores rodaram estudos de eventos para cada caso individual, assim como para o conjunto de empresas com dados disponíveis. Os resultados indicam que, na média, uma denúncia impacta negativamente o preço das açôes da empresa denunciada, o que seria um indicativo de que o programa possui alguma efetividade, a despeito de seu caráter voluntário.

O quinto artigo, também de autoria de Luíza Mônica Assis da Silva, debruça-se sobre o conteúdo das alegaçóes de violação das Diretrizes da OCDE recebidas pelo PCN-Brasil. Por meio de análise lexical dos sumários das alegaçóes disponíveis no site da agência, a autora identifica dois grandes eixos temáticos, que são rotulados de Procedimentos do PCN-Brasil e Diretrizes da OCDE para empresas multinacionais: quem denuncia e o que denuncia. Entre os achados do estudo, talvez o mais importante seja a pouca relevância, em termos de frequência com que aparecem nos sumários, de 
termos relativos à "essência" do papel dos PCNs, tais como conciliação, consenso, solução, resolução, remediação e reparação. Conforme a autora, isso é um indício de que o PCN-Brasil não tem sido capaz de convencer as empresas a participarem dos processos de mediaçáo.

O sexto artigo, escrito por Ignácio Tavares de Araújo Júnior, faz uma revisão da literatura teórica sobre acordos de investimento. Após uma análise dos efeitos esperados dos TBIs sobre o IDE, o autor examina alguns aspectos específicos, como o impacto das cláusulas de resolução de disputas investor-Estado. Na parte final, o autor discute algumas tendências verificadas em período recente, entre elas o encerramento de diversos acordos, motivado, em grande medida, por discordâncias em relação a processos de arbitragem internacional, e o surgimento de novos modelos, que buscam ampliar o espaço dos Estados signatários para a adoção de políticas públicas em áreas como saúde e meio ambiente, sem incorrer no risco de serem acusados pelas EMNs de expropriação indireta (por conta da redução nos lucros esperados), além de conter cláusulas de soluçáo de disputas mais brandas, que enfatizam a necessidade de esgotamento das instâncias locais.

O modelo brasileiro de acordo de investimentos é o tema do sétimo artigo, assinado por Ana Garcia e Gabriel Torres. Tomando por base os ACFIs assinados com Angola e Moçambique, é realizada uma comparação entre a proposta brasileira e os modelos convencionais de TBIs. Os autores concluem que o ACFI possui aspectos inovadores que atenuam alguns elementos críticos dos TBIs tradicionais, como, por exemplo, a não inclusão de cláusulas alusivas à expropriação indireta e a substituição da cláusula de arbitragem investidor-Estado pela arbitragem Estado-Estado, que, por seu turno, só deve ser invocada após o esgotamento de outros mecanismos de resolução de conflitos.

O oitavo artigo, também de autoria de Ignácio Tavares de Araújo Júnior, traz uma análise quantitativa do efeito dos TBIs sobre os fluxos de IDE para os países da América Latina. Após revisar os achados de estudos empíricos anteriores, o autor apresenta os resultados de um conjunto de estimaçóes envolvendo o efeito direto de um TBI sobre os fluxos bilaterais de IDE, assim como os efeitos causados, sobre os mesmos fluxos, por reclamaçóes de violação de TBIs em tribunais internacionais. Mesmo usando diversas especificaçóes, o estudo não foi capaz de identificar uma relação estatisticamente significativa entre o ingresso de IDE e a ratificação de um acordo de investimento. Por seu turno, denúncias de violação de TBIs em tribunais internacionais parecem surtir efeito negativo sobre os fluxos de IDE para países da América Latina.

Por fim, no nono artigo, Marina Sanches Wünsch e Fábio Costa Morosini conjugam os dois temas cobertos nesta edição especial ao debruçarem-se sobre os acordos de investimento enquanto veículos para a difusão de ideias sobre responsabilidade social corporativa (RSC). Adotando uma perspectiva crítica, os autores relacionam as origens do movimento de RSC à ascensão política do ideário neoliberal, a partir de fins dos anos 1970, o que acaba por moldar sua principal característica: a voluntariedade. A inclusáo de cláusulas de RSC em acordos de investimento é analisada na sequência, abordando inclusive o ACFI. Embora reconheçam avanços no modelo proposto pelo Brasil, que provê mais estímulos à inclusão desse tipo de cláusula em acordos concretos, os autores ressaltam que a RSC continua sendo tratada por meio de soft law, ou seja, regulação não vinculante de caráter essencialmente voluntário. Ao final, os autores encaminham algumas propostas para tornar as cláusulas de RSC mais efetivas, como, por exemplo, a vinculação explícita dos ACFIs a tratados internacionais de direitos humanos ratificados pelo Brasil e a inclusão de cláusula de extraterritorialidade, que reduziria os ganhos propiciados às EMNs pela "arbitragem de proteção de direitos humanos". 
Espera-se, com esse conjunto de artigos, escrito por autores com diferentes formações, visões de mundo e vinculaçôes teóricas, contribuir ao necessário debate sobre a regulação do investimento estrangeiro, especialmente quanto aos temas atinentes à proteção dos investidores e das comunidades impactadas pela atuação das multinacionais.

André Gustavo de Miranda Pineli Alves

Editor

Técnico de planejamento e pesquisa na Diretoria de Estudos e Relaçóes Econômicas e Políticas Internacionais (Dinte) do Ipea 


\title{
MECANISMO DA OCDE SOBRE CONDUTA EMPRESARIAL RESPONSÁVEL: EVIDÊNCIAS DO BRASIL E DE PAÍSES-MEMBROS DA OCDE E SUAS IMPLICAÇÕES
}

Edmundo Inácio Júnior ${ }^{1}$

Cássio Garcia Ribeiro²

\begin{abstract}
SINOPSE
A finalidade deste artigo é apresentar e analisar os impactos das normas e recomendações presentes no documento, elaborado pela Organização para a Cooperação e Desenvolvimento Econômico (OCDE), intitulado Diretrizes para Empresas Multinacionais (OECD, 2011). Dado que as empresas de vários setores têm buscado oportunidades fora do país de origem, pode-se afirmar que o objetivo das diretrizes é nortear a atuação dessas empresas multinacionais (EMNs) nos países hospedeiros. 0 tema é pertinente, pois uma série de estudos tem evidenciado os impactos positivos que esse movimento traz aos países receptores de investimento direto estrangeiro (IDE). Entretanto, a literatura também aponta para a possibilidade de a atuação das EMNs nos países hospedeiros resultar em efeitos colaterais. Cumpre ressaltar que o governo brasileiro aderiu às diretrizes em 1997 e desde então tem se empenhado para se adequar ao conteúdo dessa normativa da OCDE.
\end{abstract}

Palavras-chave: diretrizes; empresas multinacionais; ponto de contato nacional.

\begin{abstract}
The purpose of this article is to present and analyze the impacts of the standards and recommendations present in the document, prepared by the Organization for Economic Cooperation and Development (OECD), entitled Guidelines for Multinational Enterprises (MNEs) (OECD, 2011). Given that companies from various sectors have sought opportunities outside their country of origin, the Guidelines has the objective of providing acceptable practices of how theses MNEs act in host countries. The topic is pertinent, as a series of studies have highlighted the positive impacts that this movement brings to countries receiving foreign direct investment (FDI). On the other hand, the literature also points to the possibility of MNEs acting in host countries resulting in side effects. Brazilian government adhered to OECD Guidelines in 1997 and since then, has been striving to adapt itself to the content of this norm.
\end{abstract}

Keywords: guidelines; multinational enterprises; national contact point.

JEL: F51; F53.

Artigo recebido em 11/12/2020 e aprovado em 12/1/2021.

DOI: http://dx.doi.org/10.38116/bepi29art1

\section{INTRODUÇÃO}

Em 2017, as operaçôes estrangeiras das cem maiores empresas multinacionais (EMNs) globais representaram $9 \%$ dos ativos estrangeiros mundiais, $17 \%$ das vendas externas mundiais e $13 \%$ dos empregos estrangeiros. As principais EMNs representavam 0,1\% do universo estimado de EMNs

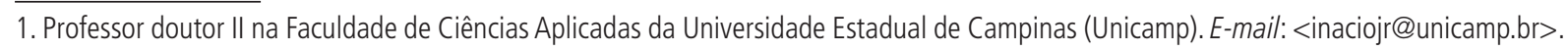
2. Professor adjunto II no Instituto de Economia e Relações Internacionais da Universidade Federal de Uberlândia (UFU).E-mail: <cassiogarcia@ufu.br>. 
naquele ano, mas suas vendas totais foram equivalentes a cerca de $10 \%$ do produto interno bruto (PIB) mundial (UNCTAD, 2018).

Os termos corporação multinacional, corporação transnacional e corporação global são frequentemente usados de forma intercambiável. A Conferência das Nações Unidas sobre Comércio e Desenvolvimento (United Nations Conference on Trade and Development - UNCTAD) define uma corporação transnacional como uma entidade composta por uma empresa que controla os ativos de entidades em outros países, além de seu país de origem. Ou seja, trata-se de uma empresa que conta com subsidiárias ou filias em outros países (Chandler e Mazlish, 2005).

O investimento direto estrangeiro (IDE) realizado pelas EMNs pode ajudar a alavancar a economia e o elevar o padrão de vida nos países hospedeiros, contribuindo com a criação de empregos, a capacitação da mão de obra, o desenvolvimento de tecnologia e a distribuição de riqueza nesses países. Além disso, o IDE pode servir como canal a partir do qual as indústrias nacionais conseguem acessar os mercados internacionais, vinculando-se a EMNs e a cadeias globais de valor.

Além dos impactos positivos proporcionados pelos investimentos das EMNs aos países hospedeiros, há que se considerar que sua atuação pode trazer também danos a tais países. A degradação ambiental, a exploração do trabalho infantil e o desrespeito às convençôes internacionais de proteção ao trabalhador são alguns exemplos de impactos danosos decorrentes da atuação das corporaçôes multinacionais nos países receptores de IDE (Bule e Less, 2016).

Portanto, é importante que sejam consideradas as duas faces do fenômeno da multinacionalização, isto é, que ele traz impactos positivos, mas também pode acarretar no surgimento em impactos danosos aos países receptores. Pode-se dizer que essa constatação motivou a Organização para a Cooperação e Desenvolvimento Econômico (OCDE) a assumir o papel de único foro internacional que explicita regras para as multinacionais, materializadas nas Diretrizes para Empresas Multinacionais. Esse documento já sofreu cinco revisóes - 1979, 1984, 1991, 2000 e 2011 - e contém princípios e padróes de Conduta Empresarial Responsável (Responsible Business Conduct) às multinacionais (OECD, 2011).

Em onze capítulos, as Diretrizes estabelecem padróes relacionados ao comportamento empresarial que abrangem uma ampla gama de questôes, tais como: direitos humanos, direitos trabalhistas, proteção ambiental, tributação, proteção ao consumidor, due diligence (devida diligência) e gestão da cadeia de fornecimento. De aplicaçáo extraterritorial e ampla em sua cobertura de setores, cadeias de valor e áreas de impacto corporativo, as Diretrizes estabelecem expectativas de longo alcance para a responsabilidade das empresas de contabilizar as externalidades negativas de suas operaçóes.

O governo brasileiro aderiu às Diretrizes em 1997 e desde então tem realizado esforços para se adequar ao conteúdo desse instrumento da OCDE voltado às EMNs (Thorstensen, Cortellini e Gullo, 2018). O objetivo deste estudo é avaliar o impacto de um dos mecanismos das Diretrizes, qual seja, a Conduta Empresarial Responsável (Responsible Business Conduct) sobre a governança e o modo de atuação das empresas multinacionais.

A metodologia adotada no artigo se apoia em revisão das literaturas que abordam os temas das empresas multinacionais e das Diretrizes para Empresas Multinacionais da OCDE; e pesquisa documental assentada em relatórios da OCDE e da OCDE Watch. O artigo conta com cinco seçóes além desta introdução. A seção 2 foca a OCDE e suas Diretrizes para Empresas Multinacionais. 
A seção 3 aborda a influência das Diretrizes sobre as agendas dos governos nacionais. Na seção 4 é discutido o rebatimento das Diretrizes sobre as políticas das EMNs. A seção 5 apresenta um conjunto de tabulaçóes, com vistas a elucidar os casos de alegaçóes de inobservância às Diretrizes recebidos pelo ponto de contato nacional (PCN) brasileiro, bem como ao conjunto dos casos submetidos aos PCNs dos países da OECD (48 países aderentes). Finalmente, na seção 6 são apresentadas as conclusóes do estudo, suas limitaçóes e sugestôes de trabalhos futuros.

\section{A OCDE E AS DIRETRIZES PARA EMPRESAS MULTINACIONAIS}

Desde a década de 1970, quando o fenômeno da multinacionalização ainda era relativamente recente, a OCDE já se debruçava sobre ele. Motivada por essa preocupação, o antigo Comitê de Investimento Estrangeiro e Empresas Multinacionais da OCDE elaborou as chamadas Diretrizes para Empresas Multinacionais. ${ }^{3}$ Tal arcabouço foi concebido em conjunto e representa um anexo da Declaraçâo da OCDE sobre Investimento Estrangeiro e Empresas Multinacionais (Reinert, Reinert e Debebe, 2016).

A Declaração teve por finalidade estimular os investimentos estrangeiros por meio da adoção de medidas conjuntas pelos países-membros, robustecendo os laços entre EMNs e os Estados. O objetivo precípuo da Declaração foi estimular as contribuiçóes positivas das EMNs do ponto de vista econômico e social aos Estados hospedeiros e, concomitantemente, minimizar e contribuir para a resolução dos impactos negativos decorrentes das atividades dessas corporaçóes (OECD, 2021).

As Diretrizes fornecem princípios voluntários e padróes de conduta responsável para empresas, abarcando temas como emprego e relaçóes trabalhistas, direitos humanos, meio ambiente, entre outros. Em relação às expectativas em torno da conduta empresarial responsável, pode-se afirmar que elas se apoiam no pressuposto de que todas as EMNs - independentemente de seu status legal, tamanho, estrutura acionária ou setor - devem trazer uma contribuição positiva para o progresso econômico, ambiental e social dos países em que elas operam. Portanto, o conceito de conduta empresarial responsável (CER) é um dos pilares das Diretrizes. Tal conceito encerra tanto a percepção de que as EMNs não devem causar danos aos países hospedeiros, quanto à ideia de é sua obrigação dar conta desses impactos quando eles ocorrerem. A observância da conduta empresarial responsável se aplica às operaçóes diretas de uma empresa, bem como a produtos, operaçóes e serviços em toda a sua cadeia de suprimentos (OECD, 2011).

A implementação de práticas e condutas aderentes a uma conduta empresarial responsável exige que as EMNs adotem mecanismos de due dilligence, ou devida diligência. Esse conceito envolve a adoção de um sistema de gestáo por meio do qual essas empresas identifiquem, impeçam e mitiguem os impactos adversos reais e potenciais decorrentes de sua atividade, bem como das empresas que compóem sua cadeia de fornecedores (Schappert, 2016).

É importante destacar que as Diretrizes têm algumas características que contribuíram para a maior aceitaçáo por parte dos países-membros e aderentes. Em primeiro lugar, o fato de sua observância ser voluntária. Elas sáo de cumprimento voluntário por parte das EMNs, no entanto, os governos aderentes são obrigados a observar e promover suas normas. Nesse sentido, pode-se afirmar que representam

3. As Diretrizes empregam a seguinte definição para as empresas multinacionais: são corporaç̧ões localizadas em mais de um país, contanto que tenham laços estreitos o suficiente de modo a tornar possível a coordenação de suas operações, não importando se o capital que as constituem é privado, público ou misto, tampouco seu porte e ramo de atividade (OECD, 2011). 
um mecanismo de autoridade persuasiva ou soft law, pelo seu caráter voluntário (especificamente em relação às EMNs) e sem força de aplicação coercitiva (Tripodi, 2014).

Além disso, parte-se de uma abordagem equilibrada, ou seja, de um esforço para que sejam evitados mal-entendidos e seja construída uma atmosfera de confiança mútua e de previsibilidade entre empresas, trabalhadores e governos (OECD, 2011). No que diz respeito às políticas gerais voltadas para as EMNs, as normas que constituem as Diretrizes se apoiam na importância do desenvolvimento sustentável e respeito aos direitos humanos.

A estrutura institucional para promover e implementar as Diretrizes é descrita no Conselho de Decisão da OCDE. Consiste de três elementos principais: o Comitê da OCDE para Investimentos Internacionais e Empresas Multinacionais (CIME) (ver figura 1); os PCNs; e os Comitês consultivos da OCDE. O PCN - geralmente um escritório do governo - é responsável por incentivar a observância das Diretrizes em seu contexto nacional e por assegurar que sejam bem conhecidas e compreendidas pela comunidade empresarial nacional e por outras partes interessadas.

FIGURA 1

Estrutura do CIME

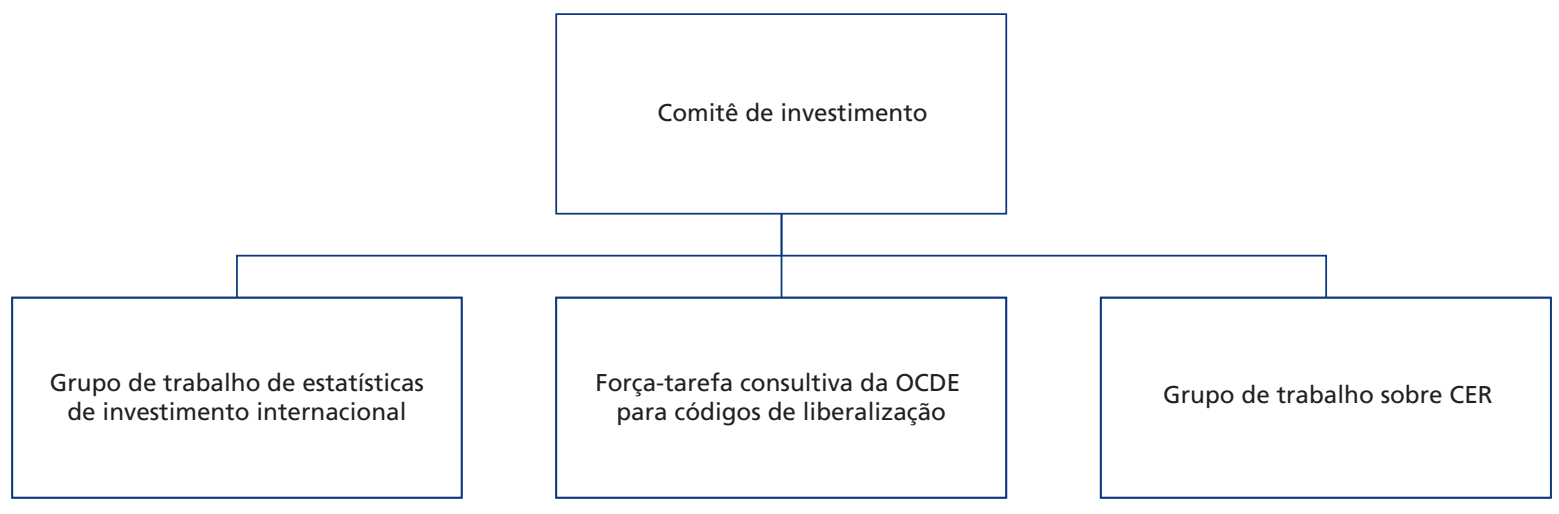

Fonte: OECD (2020)

Elaboração dos autores.

Os PCNs devem se incumbir de promover as Diretrizes internamente. Além disso, responsabilizam-se pela implementação do mecanismo de recepção de denúncias e resolução das alegaçóes de inobservância às Diretrizes pelas EMNs (Ruggie e Nelson, 2015). Os PCNs são um órgão não judicial baseado no Estado, que funcionam como um mecanismo de resolução de disputas entre as EMNs e os alegantes, como organizaçóes não governamentais (ONGs), sindicatos e comunidades locais (Robinson, 2014). Portanto, os PCNs podem ser caracterizados como fiscais do cumprimento das Diretrizes por parte das EMNs.

Embora o próprio CIME possa organizar atividades como simpósios, seminários ou conferências, a promoção e a divulgação de informaçôes sobre as Diretrizes são essencialmente papéis dos PCNs. Os PCNs têm a responsabilidade de torná-las mais conhecidas e acessíveis, inclusive com a divulgação de material nas línguas nacionais. Também se incumbem de fornecer aos possíveis investidores, internos e externos, informaçôes sobre tais regras. Em seus esforços de divulgação, os PCNs cooperam com grande variedade de organizaçóes e indivíduos, incluindo, quando apropriado, a comunidade empresarial, as organizaçóes trabalhistas, outras ONGs e o público interessado. 
Cumpre ressaltar que os PCNs possuem flexibilidade para o tratamento dos casos submetidos. Tal flexibilidade se observa mesmo antes da abertura de uma alegação de inobservância, uma vez que eles podem ser contatados por potenciais "submissores" que buscam entender as minúcias do processo. Os PCNs podem oferecer seus "bons ofícios", que varia entre a promoçáo de conversas bilaterais entre as partes, conciliação ou mediação mais formal. Finalmente, o resultado das alegaçóes de inobservância avaliadas pelos PCNs pode assumir uma variedade de formas, dependendo do perfil do PCN, das circunstâncias do processo e do que está sendo buscado pelos solicitantes.

Os PCNs, conforme sugerem as Diretrizes, devem enviar anualmente relatórios de gestáo ao CIME. O CIME, por sua vez, quando requisitado pelo PCN, deve prestar assistência, principalmente em casos de dúvidas sobre a interpretação das Diretrizes de situaçôes sui generis (OECD, 2011). Além disso, como o CIME abarca todos os países-membros e observadores da OCDE, sua responsabilidade aplica-se náo somente às Diretrizes, ou seja, auxiliar no funcionamento e tomar medidas para aumentar a sua eficácia, mas também abarca todos os elementos da Declaraçáo sobre Investimento Internacional e Empresas Multinacionais. O CIME, tendo em vista o papel de supervisor do funcionamento das Diretrizes, promove fóruns de discussóes que reúnem policymakers, a OCDE Watch (uma rede internacional de ONGs) e representantes de entidades trabalhistas e empresariais, tais como o Trade Union Advisory Committee (TUAC) e o Business and Industry Advisory Committee (BIAC). Cabe observar que esses três organismos (TUAC, BIAC e OCDE Watch) são convocados de maneira periódica pelo CIME e pelo Grupo de Trabalho sobre CER para apresentarem seus pareceres contendo avaliaçôes e recomendaçóes acerca das Diretrizes (OECD, 2015). A figura 2 mostra as relaçôes entre esses organismos.

FIGURA 2

Instituições envolvidas na implementação das Diretrizes

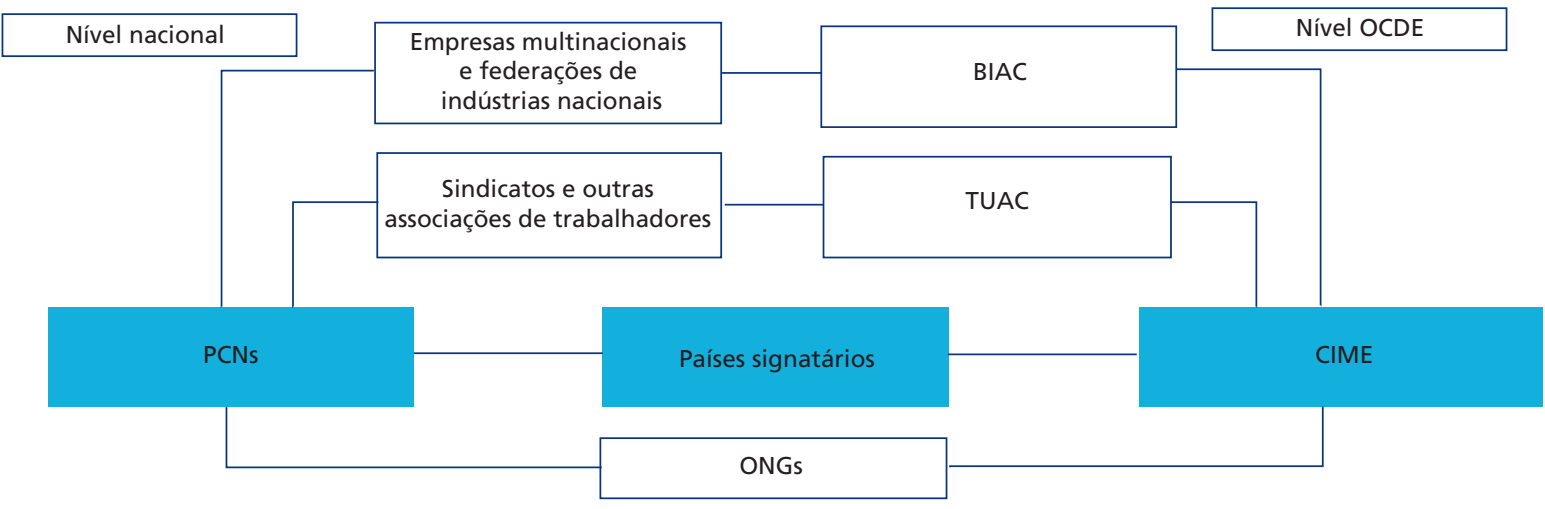

Fonte: OECD (2001).

Elaboração dos autores.

Portanto, no plano internacional, considera-se de fundamental importância a participação das partes interessadas, tais como o BIAC e o TUAC, para o efetivo funcionamento das Diretrizes. Já no plano nacional, os sindicatos de trabalhadores e as empresas, bem como as ONGs, são responsáveis por monitorar, acompanhar a implementaçáo e a observância das Diretrizes.

É evidente que desde 1976, ano em que foi publicada a primeira versão das Diretrizes, o processo de globalizaçáo se intensificou, tendo como um de seus principais protagonistas as EMNs. Concomitantemente, alguns problemas persistiram e/ou foram aprofundados, tais como o trabalho 
escravo e infantil; a degradação ambiental; e a corrupção. Embora esses impactos não possam ser atribuídos apenas à globalização e às EMNs, em muitos casos o são. Além disso, a complexidade das cadeias de fornecimento globais pode, diversas vezes, levar à subcontratação e ao aumento de problemas dessa natureza.

Nesse sentido, desde a versão original, as Diretrizes já sofreram cinco revisões (em 1979, 1984, 1991, 2000 e 2011). As preocupaçóes da sociedade acerca do impacto causado pelo aprofundamento da globalização também tiveram um peso nessa revisão. Foram realizadas consultas junto à comunidade empresarial, representantes trabalhistas, ONGs e governos não membros. Todos esses atores trouxeram insumos e recomendaçôes para as revisôes com vistas a aperfeiçoá-las e a melhorar a implementação dos procedimentos que a compóem (OECD, 2011).

\section{INFLUÊNCIA DAS DIRETRIZES SOBRE AS AGENDAS DOS GOVERNOS NACIONAIS}

Durante a reunião ministerial em comemoração ao 50ำ aniversário da OCDE, em 2011, a nova versão das Diretrizes foi aprovada por 42 governos (OECD, 2011). Cumpre destacar que, além dos 37 países-membros da OCDE à época, outros países não membros também aderiram às Diretrizes, a saber: Argentina, Brasil, Letônia, Lituânia, Marrocos, Peru e Romênia. Na atualidade são 48 os países aderentes $^{4}$ da Declaração da OCDE sobre Investimento Internacional e Empresas Multinacionais, da qual as Diretrizes são parte. Conforme já destacado, a adesão às Diretrizes é aberta e incentivada aos países não membros da $\mathrm{OCDE}$.

Não obstante o fato de as Diretrizes não serem vinculantes para as empresas, os governos aderentes se comprometem a implementá-las e têm a obrigação de estabelecer PCNs. O papel dos PCNs é promover as Diretrizes, além de receber e avaliar casos de possíveis condutas inadequadas pelas EMNs vis-à-vis às regras estabelecidas. Os governos têm um papel importante a desempenhar na habilitação e promoçáo da chamada conduta empresarial responsável entre as EMNs, trabalhando em parceria não apenas com elas, mas também como os sindicatos, a sociedade civil, o público em geral e outros governos, com vistas a criar sinergias e incentivar a implementação das Diretrizes (Bule e Less, 2016).

Do ponto de vista de sua força jurídica, é importante salientar que as Diretrizes estabelecem princípios e padróes voluntários para uma conduta empresarial responsável, que seja aderente às leis e aos padrốes consagrados no âmbito internacional. Portanto, elas "não possuem caráter juridicamente vinculante, pois possuem natureza de declarações e recomendaçóes" (Thorstensen, Cortellini e Gullo, 2018, p. 16). Todavia, há um compromisso vinculante assumido pelos países que aderem às Diretrizes no sentido de implementá-las de acordo com as deliberaçôes do Conselho da OCDE. Ademais, os temas abarcados pelas Diretrizes também podem ser objetos das legislaçóes nacionais dos países aderentes, bem como de compromissos internacionais.

Cumpre ressaltar que o objetivo que se propôs a alcançar com a criação dos PCNs foi facilitar o acesso a meios consensuais e não contraditórios - como conciliação ou mediação - de modo a auxiliar as partes a lidar com os contenciosos em relação aos quais estão envolvidas. Assim, pretendeu-se

4. Argentina, Austrália, Áustria, Bélgica, Brasil, Canadá, Chile, Colômbia, Costa Rica, República Tcheca, Dinamarca, Egito, Estônia, Finlândia, França, Alemanha, Grécia, Hungria, Islândia, Irlanda, Israel, Itália, Japão, Jordânia, Cazaquistão, Coreia, Letônia, Lituânia, Luxemburgo, México, Marrocos, Holanda, Nova Zelândia, Noruega, Peru, Polônia, Portugal, Romênia, Eslováquia, Eslovênia, Espanha, Suécia, Suiç̧a, Tunísia, Turquia, Ucrânia, Reino Unido e Estados Unidos. 
criar um sistema que tivesse como foco a solução de conflitos que oferecesse às partes envolvidas um melhor nível de controle na obtenção de um acordo, comparativamente aos processos mais formais, em que terceiros tomam decisóes finais e vinculativas. Além disso, por envolver queixas não judiciais, tal sistema foi pensado para ser significativamente mais rápido e econômico (Bule e Less, 2016).

Mesmo em situaçôes em que um acordo não seja possível, pode ser visto como um resultado positivo do sistema de soluçáo de conflitos quando há: i) a emissão de um parecer atestando que houve violação dos princípios; e ii) a apresentação de recomendaçóes à empresa envolvida sobre como proceder para reparar os danos causados. Portanto, não deve ser subestimada a importância das declaraçóes de inobservância emitidas por um PCN, ao examinar as alegaçóes e concluir que de fato a EMN envolvida violou as Diretrizes (OECD Watch, 2019).

Portanto, é possível identificar alguns resultados concretos que foram alcançados a partir do sistema de soluçáo de conflitos previsto pelas Diretrizes. Nieuwenkamp (2016) afirma que os PCNs contribuíram para a aboliçáo do trabalho forçado e infantil nas cadeias de suprimentos de vestuário; a melhoria na saúde e na segurança dos trabalhadores agrícolas; o aprimorando da devida diligência em direitos humanos para megaeventos esportivos; e a elaboração de pareceres de compensaçóes a comunidades indígenas atingidas por atividades das EMNs.

Em que pesem os resultados positivos destacados pela literatura a partir da atuação dos PCNs, a partir da pesquisa (bibliográfica e documental) realizada também foi possível identificar críticas incisivas a esse sistema de mediação de conflitos entre as EMNs e os alegantes dos países hospedeiros. Segundo Acconci (2001), os PCNs deveriam ter promovido uma melhoria real na conduta das EMNs e, portanto, garantir a eficácia do acompanhamento das Diretrizes. Todavia, de acordo com o autor, a partir do exame dos conflitos envolvendo as EMNs fora dos países de origem, não é isso que se observa na maioria dos casos.

Segundo Bule e Less (2016), são poucos os exemplos de sucesso alcançados pelos PCNs locais, o que evidencia o não cumprimento do enorme potencial das Diretrizes. Os autores vão além e afirmam que quase todos os PCNs são insuficientemente financiados por seus governos. Ademais, de acordo com eles, raramente há consequências concretas às EMNs que atuaram em desacordo com as regras das Diretrizes. Na visão de Černič (2008), as fraquezas subjacentes às Diretrizes podem ser explicadas por sua natureza inexequível. Segundo o autor, há uma disparidade considerável entre os compromissos endossados pelos governos e a efetiva implementação das Diretrizes. Além disso, como a maioria dos PCNs está inserida em ministérios ou departamentos ligados à indústria e atividades empresariais, aparentemente eles estariam mais inclinados a ficar do lado das EMNs e não dos alegantes (Černič, 2008).

Černič (2008) identifica alguns problemas recorrentes na atuação dos PCNs, quais sejam: i) a ausência de procedimentos claros na condução dos casos e a inexistência de tempo limite para interposição de reclamaçóes; ii) o tratamento desigual concedido às partes; iii) os encargos que recaem sobre os alegantes; iv) a falta de vontade de investigar e a incapacidade de apurar os fatos; v) a falta de transparência no que se refere à aplicação das Diretrizes; vi) a não inclusão das cadeias de fornecedores das EMNs nos casos em que notoriamente elas estejam envolvidas; e vii) a falta de vontade de emitir pareceres explicitando que ocorreram violaçóes das Diretrizes, quando essa é a conclusão efetiva da análise dos contenciosos. 
Robinson (2014) afirma que os Estados dos países-membros da OCDE e daqueles países que aderiram às Diretrizes muitas vezes se desresponsabilizam quando seu PCN deixa de agir adequadamente. Assim, sem o apoio dos Estados, tais esforços serão malogrados, visto que esses continuam sendo os principais sujeitos de direito público internacional (Robinson, 2014).

Foort (2016) argumenta que alguns assuntos abrangidos por regras (inter)nacionais com força legal são refletidas nas Diretrizes, conferindo-lhes um status híbrido. Tal status híbrido decorre, portanto, do fato de que as Diretrizes não constituem regras legais, mas abarcam temas que são cobertos por regras legais. Assim, por um lado, alguns princípios das Diretrizes podem ser tratados como meras expressóes de moralidade, ao imporem às EMNs obrigaçóes morais. Por outro lado, as Diretrizes se deparam com um longo e difícil caminho para alcançarem um status legal.

Frente a alguns dos problemas observados no sistema de solução de conflitos adotado pelas Diretrizes via PCNs, em 2016 os ministros da OCDE decidiram que todos os PCNs precisaráo ser revisados por pares até 2023. O propósito dessa revisão é permitir que eles se tornem um instrumento útil e imparcial. Alguns deles já foram revisados, dando ensejo ao aprimoramento de seus procedimentos, maior imparcialidade e ampliação dos recursos de que dispóem para cumprir suas funçóes de maneira mais efetiva (Nieuwenkamp, 2013).

\section{INFLUÊNCIA DAS DIRETRIZES SOBRE AS POLÍTICAS DAS EMNs}

Questôes ligadas à conduta empresarial responsável e due dilligence têm ganhado importância nas agendas de empresas que instalam filiais no exterior ou gerenciam redes de fornecedores que se localizam fora do país de origem (Fienhold, 2014). No bojo dessa discussão, cabe aqui fazer uma distinção entre responsabilidade social corporativa (RSC) e a responsabilidade corporativa. A RSC está limitada a compromissos voluntários que as empresas se comprometem a assumir, especialmente nas áreas de direitos humanos e meio ambiente. Entretanto, quando se fala em responsabilidade corporativa, deve-se ter em mente as responsabilidades dessas empresas que estão explicitadas no arcabouço legal de um país, de modo que podem ser aplicadas por meio do sistema judicial quando houver a necessidade. Neste caso, as empresas se deparam com compromissos obrigatórios, e não opcionais (Costa, 2017).

A observância das Diretrizes possui caráter voluntário (não obrigatório), não sendo, portanto, legalmente exigível. Apesar de sua natureza voluntária, elas representam o padrão internacional atual no que toca à conduta empresarial responsável das EMNs, notadamente nas áreas de direitos humanos e proteção ambiental. Assim, de acordo com Thorstensen, Cortellini e Gullo (2018, p. 16) "trata-se de instrumento com grande força moral, uma vez que representam boas práticas de governança corporativa”. No caso das EMNs, sua atuaçáo está sujeita à vigilância da sociedade civil, que pode fazer denúncias aos PCNs.

Baccaro e Mele (2011) argumentam que é improvável que o comportamento das EMNs mude simplesmente como resultado da existência das Diretrizes. Todavia, segundo tais autores, o poder de sanção branda das Diretrizes possui o potencial para alterar o comportamento dessas corporaçóes a longo prazo, especialmente se por meio de sua aplicação seja possível aprimorar o sistema a partir do qual são discriminados os bons e os maus desempenhos. 
Apesar das dificuldades de se atribuir relação de causalidade entre as Diretrizes e a modificação no comportamento das EMNs em termos de conduta empresarial responsável e due dilligence, é possível afirmar que elas têm se tornado um dos principais benchmarks globais na área de RSC, e influenciam a expectativa dos governos em torno das EMNs que ingressam em seus países. O relatório da OCDE Watch (Olzendiel, Wilde-Ranzing e Feeney, 2010) assevera que as Diretrizes influenciaram instrumentos como o Pacto Global 5 e a ISO 26000, ${ }^{6}$ os quais reforçam, em alguma medida, a importância de que as empresas implementem políticas de RSC e due dilligence.

No atual estágio da globalização, caracterizado pela ampla utilização das tecnologias de informação e comunicação (TICs), eventuais impactos negativos decorrentes da atuação de EMNs podem ser divulgados rapidamente e em escala global por parte da mídia, influenciando consumidores e investidores, por exemplo. Portanto, não obstante o fato de que as Diretrizes representam um conjunto de recomendaçôes de cumprimento voluntário pelas corporaçóes multinacionais, tais recomendaçóes não devem ser desprezadas. Nieuwenkamp (2013, p. 1, tradução nossa) argumenta que as Diretrizes devem ser entendidas como "soft law com consequências pesadas", visto que as EMNs que violarem tal código poderão ter sua reputação manchada junto à opinião pública e investidores, estando sujeitas a prejuízos financeiros.

A despeito de não serem vinculativas às deliberaçóes e recomendaçóes das Diretrizes, sua observância é exigida por atores que têm podem de influenciar as políticas das EMNs, como as agências de crédito à exportação, o Banco Mundial e alguns fundos soberanos. Além disso, alguns países levam em consideração as decisóes e processos dos PCNs em relação à sua diplomacia comercial (Nieuwenkamp, 2016).

Portanto, o descaso dessas empresas às alegaçóes decorrentes de práticas que infringem as normas das Diretrizes, bem como a inobservância das decisóes tomadas pelos PCNs nacionais no sentido de que sejam reparados os danos causados aos alegantes, podem afetar a reputação das corporaçóes multinacionais. Há casos relatados pela literatura em que os acionistas de EMNs resolveram vender suas açóes como forma de protesto ao identificarem condutas inadequadas. Esse pode ser o motivo que levou as empresas envolvidas no desastre da Samarco a agirem com rapidez, atualizando suas páginas com informaçóes sobre o que estavam fazendo para controlar e impedir danos ambientais mais severos (Costa, 2017).

Ainda no que diz respeito à preocupação com a imagem junto ao público, de acordo com Acconci (2001), há situaçôes em que as EMNs se engajam na criação e implementação de um código de conduta justamente como reação a críticas recebidas em função do impacto danoso em alguma área em particular (como meio ambiente e direito trabalhista). O autor cita os princípios de conduta adotados pela Reebok, Nike e Levi Strauss, a fim de melhorar as condiçôes de trabalho nas fábricas de empresas subcontradas no exterior, em que são levadas a cabo algumas etapas da fabricação de seus produtos.

5. Trata-se de uma iniciativa da Organização das Nações Unidas (ONU) cuja finalidade é mobilizar a comunidade empresarial internacional a adotar códigos de conduta que introjetem valores (fundamentais e internacionalmente chancelados) acerca de temas como meio ambiente, combate à corrupção, direitos humanos e relações de trabalho (Gonzalez-Perez e Leonard, 2017).

6. A ISO 26000 gira em torno da responsabilidade social das empresas e organizações, fornecendo orientações sobre como devem agir para que seu comportamento possa ser classificado como ético e transparente, de maneira a contribuir para a saúde e o bem-estar da sociedade. Disponível em: <http://www.inmetro.gov.br/qualidade/responsabilidade_social/iso26000.asp>. 
No tocante à proteção ambiental, empresas como a General Motors, a Polaroid e a Sun Oil aderiram aos chamados Princípios CERES, anteriormente denominados Princípios de Valdez, elaborados em 1989 pela Coalizão de Economia Ambientalmente Responsável (Coalition for Environmentally Responsible Economies - CERES), por quinze principais grupos ambientais dos Estados Unidos. O grau de detalhamento dos Princípios CERES é destacado por Acconci (2001), que chama a atenção também para o fato de que sua implementação dá ensejo a um sistema de controle bastante preciso de sua conformidade, a partir da publicação de um relatório anual de cada empresa aderente.

Há situaçôes em que a adoção de princípios de conduta nos negócios é resultado de um esforço de organizaçóes internacionais - tais como ONU, Fundo das Naçóes Unidas para a Infância (United Nations International Children's Emergency Fund - Unicef), International Labor Organization/International Programme on the Elimination os Child Labor (ILO/IPEC) - e de iniciativas de associaçóes de empresas com o objetivo de padronizar o comportamento de seus membros. A Organizaçáo Internacional do Trabalho (OIT)/IPEC, juntamente com a Unicef, assinaram em 1995 um memorando de entendimento com a Associação de Fabricantes e Exportadores de Vestuário de Bangladesh e, em 1996, estabeleceram uma parceria com os Associação de Fabricantes e Exportadores de Tapetes do Paquistão. Ainda em relaçáo ao Paquistão, vale ressaltar que, em 1997, foi elaborado um projeto pela OIT/IPEC e a UNICEF juntamente com a Câmara de Comércio de Sialkot (cidade paquistanesa) para a eliminação do trabalho infantil na indústria de bolas de futebol (Acconci, 2001; Schappert, 2016).

Fienhold (2014) analisou alguns casos de conflitos envolvendo EMNs (fora de seu país de origem) e partes interessadas. $\mathrm{O}$ autor chegou à conclusão de que a gestão de conflitos, representada pelas açóes tomadas por essas empresas em resposta ao embate, é um aspecto crucial para evitar que essa situaçáo traga consequências indesejáveis a elas (como perda de mercado, deterioração de sua imagem junto ao público e queda no valor de suas açóes). Ao contrário, com base nos casos sobre os quais se debruçou, o autor afirma que a má gestão de crises pode trazer sérios problemas às EMNs. Concluindo, com base na pesquisa bibliográfica e documental realizada para a elaboraçáo deste estudo, é possível tecer alguns comentários acerca da influência das Diretrizes sobre as políticas adotadas pelas EMNs em matéria de conduta empresarial responsável e due dilligence, relacionados a seguir.

- Não obstante as dificuldades de se atribuir relação de causalidade entre as Diretrizes e alteraçóes nas condutas das EMNs, tal marco seguido pelos países-membros da OCDE e pelos países aderentes pode ser considerado um dos mais importantes benchmarks globais na área de RSC.

- $\quad$ O fato de as Diretrizes influenciarem instrumentos como o Pacto Global e o ISO 26000 revela por um lado sua credibilidade, por outro, reforça entre as EMNs a importância da responsabilidade social corporativa e de que se engajem na elaboração e implementaçáo de códigos de conduta associados a temas como meio ambiente, combate à corrupçáo, direitos humanos e relaçôes de trabalho.

- Pode-se afirmar que, em algumas situaçóes, a adoção de políticas de RSC e de devida diligência não pode ser associada diretamente às Diretrizes, mas sim a pressóes exercidas por outras organizaçóes internacionais, consumidores, comunidades locais, investidores e governos nacionais. 
Apesar do fato de que, em algum grau, direta ou indiretamente, as Diretrizes estarem influenciando as políticas das EMNs, sua observância voluntária enfraquece o poder de persuasão desse marco criado pela OCDE sobre a gestão. Dada a observância voluntária das Diretrizes, os PCNs não possuem a prerrogativa de impor puniçóes às EMNs nos casos em que inobservâncias foram identificadas.

\section{RESULTADOS ALCANÇADOS A PARTIR DA APLICAÇÃO DAS DIRETRIZES}

Esta seção destina-se a uma análise comparativa entre OCDE e Brasil sobre as diversas categorias de análise das alegaçôes de inobservância às diretrizes, encerradas ${ }^{7}$ em 2018, constantes em OECD (2019). As estatísticas do Brasil também estão inseridas nesse relatório, porém de forma agregada, o que não nos permite a análise comparativa.

Sendo assim, realizamos um mapeamento nas fontes primárias disponíveis na página oficial do governo e criamos as tabulaçóes de todas as alegaçóes de inobservância recebidas pelo PCN brasileiro, entre o período de 2003 a 2018. As subseçôes a seguir exploram as dimensóes-chave dessa pesquisa com base nos dados contidos no relatório da OCDE, bem como naqueles concernentes ao Brasil.

\subsection{Status das alegações de inobservância às diretrizes}

O gráfico 1 evidencia que, das 34 alegaçóes de inobservância encerradas em 2018, no âmbito da OCDE, que compreende 48 PCNs de países pesquisados, 13 foram concluídas (38\%) e 20 não foram aceitas (59\%). Um caso específico adicional foi retirado pelo alegante antes da avaliação inicial pelo PCN (3\%). Já em relação às treze alegações concluídas, tem-se que onze (32\%) sofreram alguma mediaçáo e apenas duas (6\%) náo envolveram mediaçáo devido à recusa de engajamento das partes. Em relação aos casos que sofreram mediação tem-se que três (9\%) resultaram em alguma forma de acordo entre as partes por meio do processo do PCN, um (3\%) foi encerrado com um acordo entre as partes paralelamente ao processo do PCN e sete (20\%) não resultaram em acordo, apesar do engajamento das partes envolvidas no processo.

As alegações de inobservância recebidas pelo PCN brasileiro estão ilustradas no gráfico 2. É possível observar que, dos 27 casos registrados entre 2003 e 2018, dezenove (70\%) foram concluídos, ao passo que seis $(22 \%)$ não foram aceitos e, finalmente, dois ( $8 \%$ ) foram aceitos pelo $\mathrm{PCN}$, mas ainda se encontram em análise. Aqui já se observa uma grande diferença quando se compara a taxa de náo aceite dos PCNs da OCDE (59\%) e brasileiro (22\%). Apesar da dificuldade encontrada para se explicar o motivo de tal diferença, em todos os casos brasileiros aceitos há uma clara menção de que o pedido "reúne elementos que guardam pertinência temática com os temas abordados pelas Diretrizes; contém foco suficientemente delimitado; e apresenta informaçôes que podem ser analisadas mediante critérios objetivos". ${ }^{8}$ Em relação à média da OCDE para 2018 (59\% de não aceites), o relatório adverte que essa taxa excede os valores históricos - que se situavam entre $25 \%$ e $40 \%$ - em função do aumento de submissóes que neste último ano não estavam dentro do escopo das diretrizes (temas não contemplados em nenhum dos onze capítulos).

7. Consideram-se alegações encerradas tanto as alegações concluídas quanto aquelas que não são aceitas.

8. Mais informações na p. 10 da Declaração final Encerramento BHP-Billiton e Vale S.A. _BWI, IndustriALL, SITICOP e CNQ-CUT_22-03-18.pdf, disponível em: <www.pen.economia.gov.br>. 


\section{GRÁFICO 1}

OCDE: status das alegações de inobservância às Diretrizes encerradas em 2018

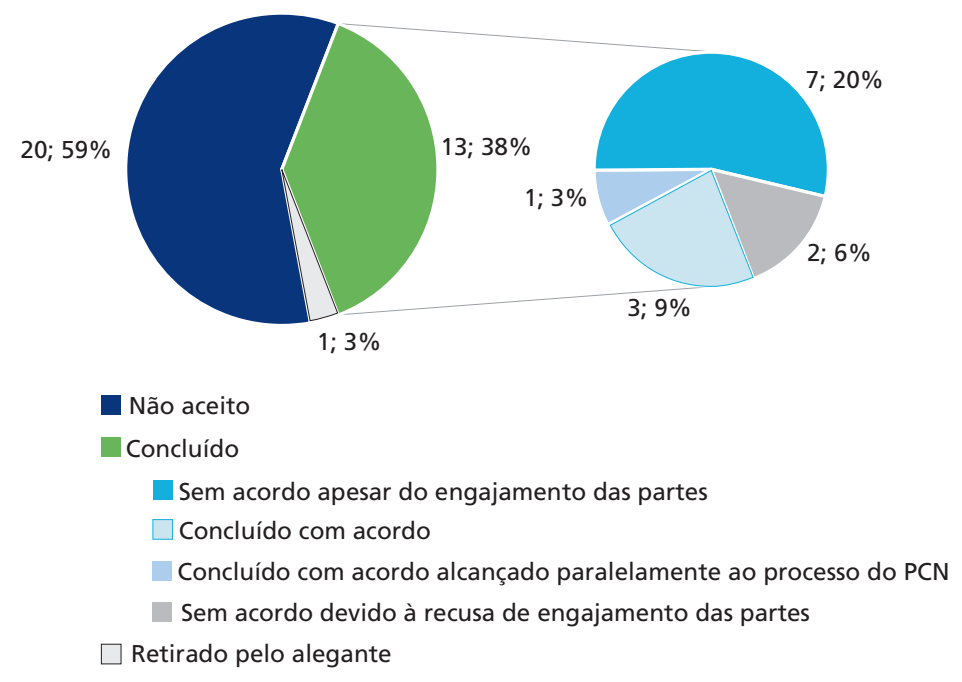

Fonte: OECD (2019)

Elaboração dos autores.

\section{GRÁFICO 2}

Brasil: status das alegações de inobservância às Diretrizes encerradas (2003-2018)

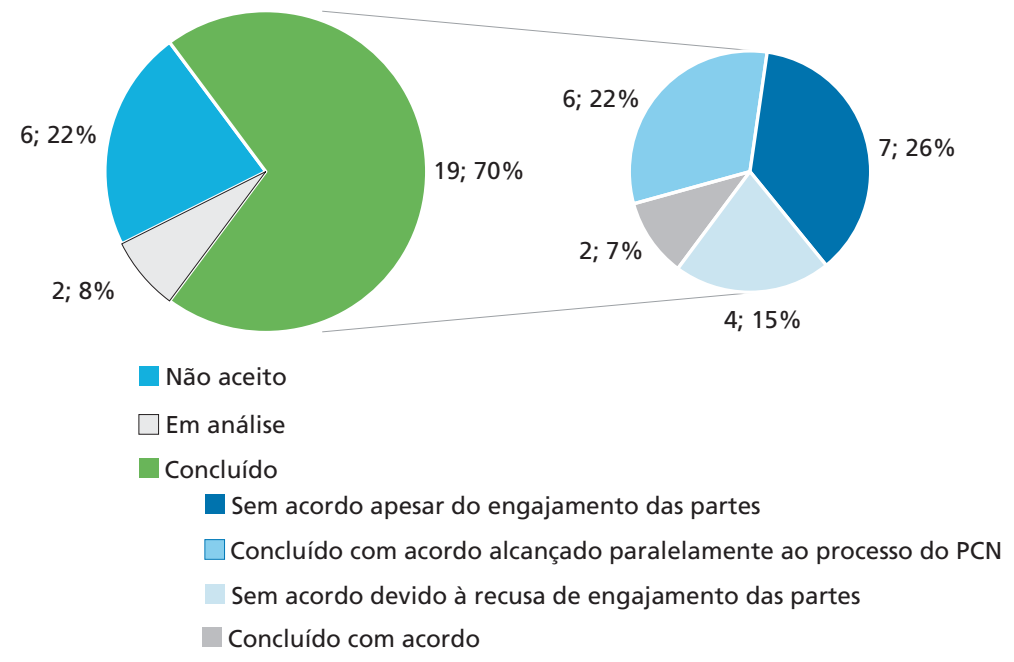

Fonte: Ministério da Economia e Fazenda. Disponível em: <http://www.fazenda.gov.br/assuntos/atuacao-internacional/ponto-de-contato-nacional/ produtos/alegacoes-de-inobservancia/banco-de-dados-das-alegacoes-de-inobservancia-das-diretrizes-da-ocde>.

Elaboração dos autores.

Examinando somente os dezenove casos aceitos e concluídos pelo PCN brasileiro, as categorias concluído com acordo e concluído sem acordo apesar do engajamento das partes têm comportamento semelhante aos casos da OCDE, sendo 9\% e 20\% da OECD contra 7\% e 26\% do PCN brasileiro, nas respectivas categorias. Em relação às categorias concluído com acordo alcançado paralelamente ao processo do $\mathrm{PCN}$ e concluído sem acordo devido à recusa de engajamento das partes, na primeira, o Brasil possui uma taxa muito superior à média da $\operatorname{OCDE~(22\% ~contra~} 3 \%)$; na segunda categoria, o país registra mais que o dobro de casos sem acordo em comparação à média da OCDE (15\% contra 6\%). 


\subsection{Duração das alegações de inobservância às Diretrizes}

O gráfico 3 evidencia que, dos 34 casos da OCDE de alegaçôes de inobservância encerrados em 2018, $26(76 \%)$ o foram em até doze meses da data de recebimento, e nos oito casos restantes (24\%), os processos duraram mais de um ano. O período de análise se estendeu por vários anos em três destes e nos cinco restantes se alongou por alguns poucos anos (em ambas as situaçóes, o relatório da OCDE não especifica qual foi a quantidade exata de anos).

Para o caso do PCN brasileiro (ver gráfico 4), para 20 dos 22 casos encerrados (dois deles ainda se encontram em análise), foi possível encontrar informaçôes que permitiram o cálculo da duração. Tem-se um quadro diametralmente oposto àquele observado na OCDE: 9\% dos casos (dois) foram concluídos dentro do período de doze meses e os vinte restantes (91\%) se estenderam por mais de um ano. Em relação a estes, em nove (41\%) o processo de análise se alongou pelo período de dois a três anos e os outros onze (50\%), entre quatro e oito anos.

Os PCNs reconheceram esse ínterim entre a submissão e a avaliação inicial como um desafio. Entretanto, as partes interessadas identificaram atrasos na avaliação como uma falha do mecanismo e observaram que a conclusão desse processo com mais celeridade tornaria o sistema mais eficaz. Em alguns casos, atrasos decorreram de extensas atividades de acompanhamento, desafios no tratamento de questóes complexas e a realização de múltiplas sessões de mediação ou diálogo, às vezes solicitadas pelas partes em casos específicos. Em algumas situaçôes, os atrasos decorreram de deficit de capacidade dos PCNs, associadas à escassez de recursos e de máo de obra que acabam por prejudicar o processo de análise das alegaçóes de inobservância dentro de um prazo razoável.

\section{GRÁFICO 3}

OCDE: duração das alegações de inobservância às Diretrizes concluídas em 2018

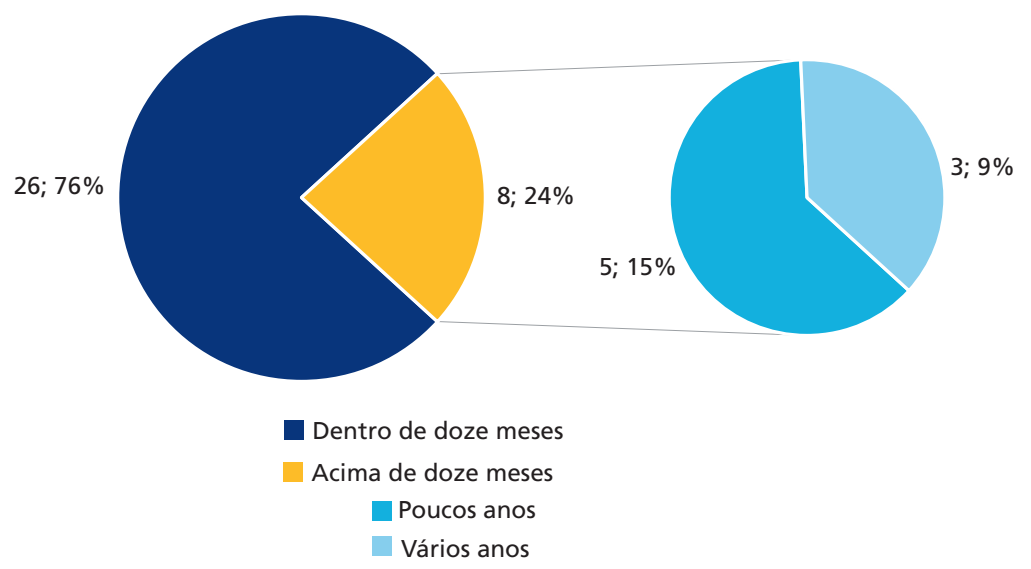

Fonte: OECD (2019).

Elaboração dos autores. 


\section{GRÁFICO 4}

Brasil: duração das alegações de inobservância às Diretrizes concluídas (2003-2018)

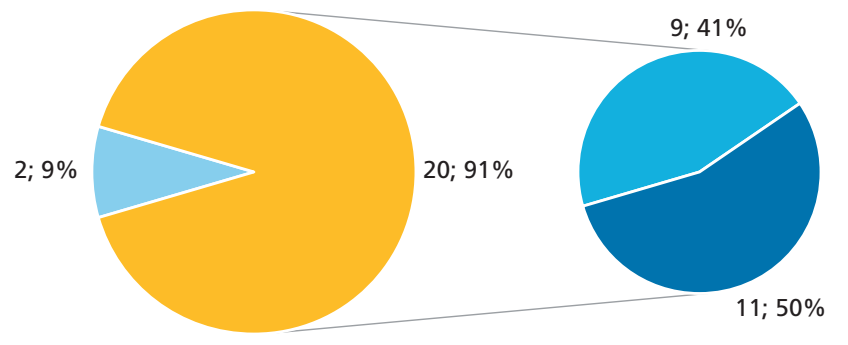

Dentro de doze meses

- Acima de doze meses

Vários anos (4 a 8)

Poucos anos (2 a 3)

Fonte: Ministério da Economia e Fazenda. Disponível em: <http://www.fazenda.gov.br/assuntos/atuacao-internacional/ponto-de-contato-nacional/ produtos/alegacoes-de-inobservancia/banco-de-dados-das-alegacoes-de-inobservancia-das-diretrizes-da-ocde>.

Elaboração dos autores.

Além do prazo de duração, as recomendações de implementação das Diretrizes também sugerem o prazo de três meses para a avaliação inicial, ou seja, após o recebimento da alegação de inobservância, o PCN teria noventa dias para comunicar se a demanda foi aceita ou náo para análises mais aprofundadas. Os dados da OCDE para 25 dos 34 casos encerrados em 2018 revelam que em nove casos $(26 \%)$ a avaliação inicial ocorreu dentro desse prazo máximo de meses; doze deles (35\%) com avaliação inicial entre três e seis meses; quatro casos restantes (12\%), acima de doze meses.

As informaçôes do PCN brasileiro acerca da avaliação inicial também foram tabuladas. O que se observou é que, a partir de 2013, a situação melhorou consideravelmente. Em todos eles, o prazo de noventa dias foi atendido, tendo-se obtido uma média de aproximadamente 42 dias para os cinco casos submetidos em 2013, 71 dias para os dois casos submetidos em 2015 e 25 dias para os dois casos submetidos em 2018. Já para os dezenove casos restantes (70\%), submetidos entre os anos de 2005 a 2012, observam-se grandes variações. Para as alegaçóes de inobservância recebidas pelo PCN brasileiro, a avaliação inicial oscilou entre 199 a 583 dias.

\subsection{Alegações de inobservância submetidas (instâncias específicas)}

Os dados da OCDE mostram que 52 alegaçóes de inobservância foram submetidas aos PCNs em 2018, em comparação a 28 apresentadas em 2017 (ver gráfico 5). Trata-se de um recorde em termos de submissóes anuais e tal quantidade é significativamente maior do que as taxas históricas de submissóes desde 2000. Considerando que o levantamento envolveu 48 PCNs ao redor do mundo, tem-se, para o ano de 2018, uma média anual de 1,08 submissão por ano e por PCN.

Para o PCN brasileiro, temos que 27 submissôes foram realizadas durante seus quinze anos (2003 a 2018) de existência (ver gráfico 6). Para esses dados, obteve-se uma média de 1,8 submissão por ano. Durante esse período, em quatro anos (2008, 2014, 2016 e 2017) não houve registro de submissóes. Por fim, dentro desse rol, duas alegaçóes de inobservância estão em análise (7\%), dezenove foram encerradas e concluídas (70\%) e seis (22\%) foram encerradas e não aceitas. 


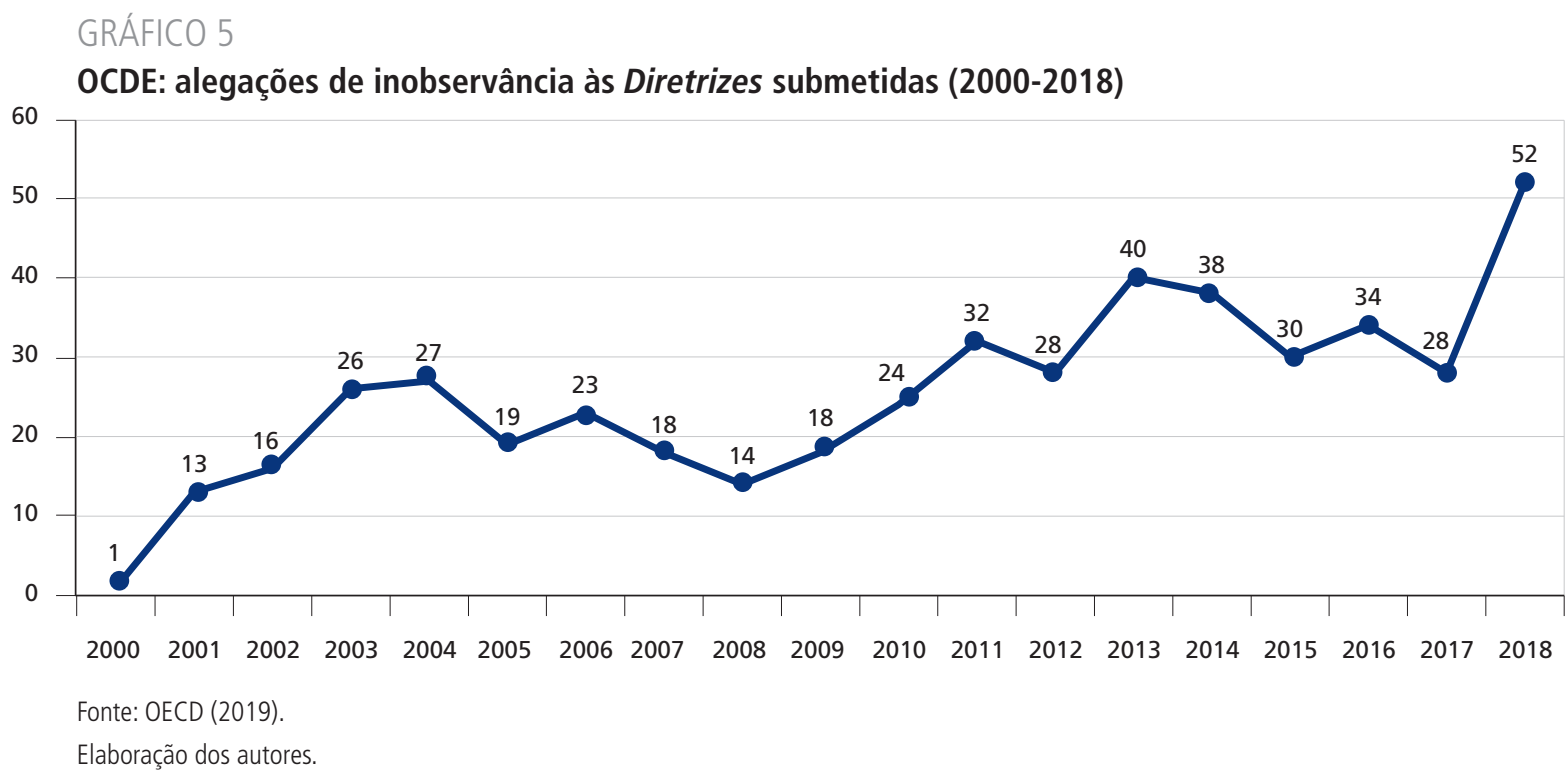

\section{GRÁFICO 6}

Brasil: alegações de inobservância às Diretrizes submetidas (2003-2018)

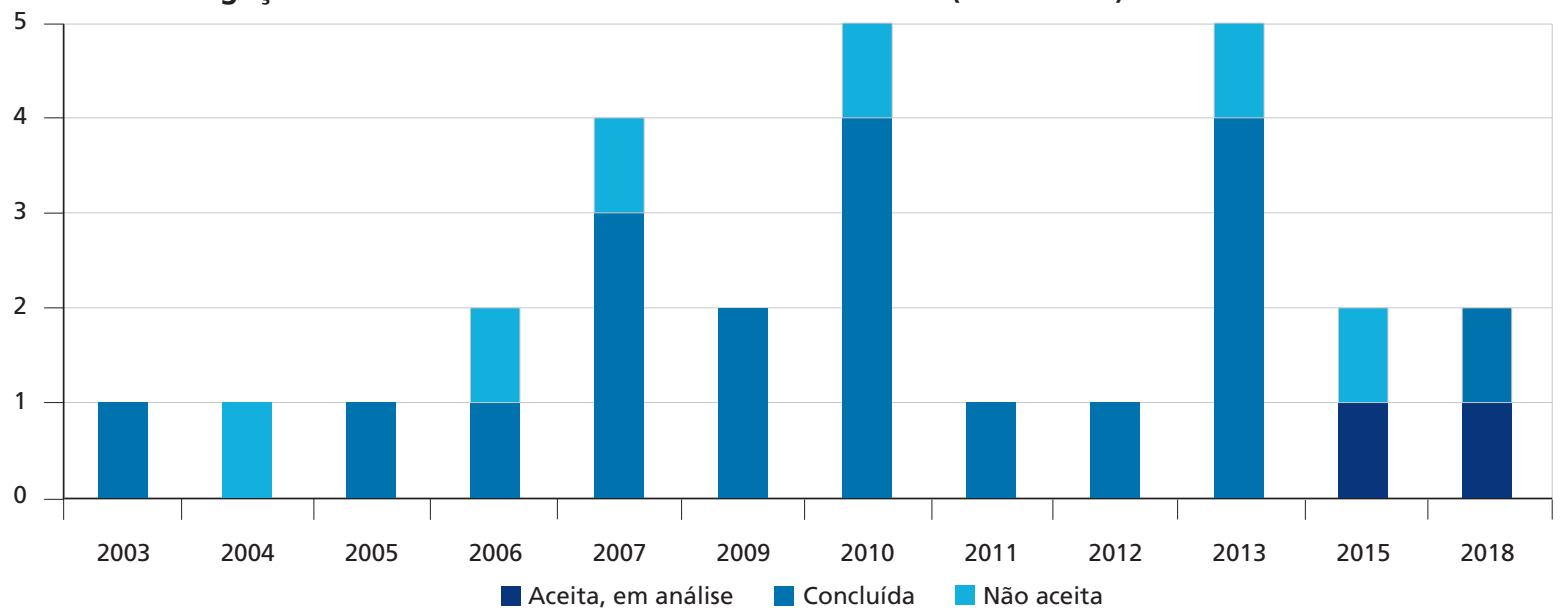

Fonte: Ministério da Economia e Fazenda. Disponível em: <http://www.fazenda.gov.br/assuntos/atuacao-internacional/ponto-de-contato-nacional/ produtos/alegacoes-de-inobservancia/banco-de-dados-das-alegacoes-de-inobservancia-das-diretrizes-da-ocde>.

\subsection{Setores das alegações de inobservância às Diretrizes}

Os setores mais prevalentes da OCDE referenciados nas alegações de inobservância apresentados em 2018, conforme o gráfico 7, foram: mineração (15\%), indústria (13\%), agricultura (11\%) e setor financeiro (11\%). Esse quadro está de acordo com as tendências históricas gerais, apesar da diminuição nas alegaçóes de inobservância envolvendo o setor financeiro, que para o período de 2015-2017 era o setor com maior incidência de submissóes, quando representou aproximadamente $20 \%$ das novas submissóes a cada ano.

No Brasil, segundo o gráfico 8, os quatro setores com maior incidência de alegaçôes de inobservância são: serviços financeiros, com oito alegaçôes (30\%); indústria de mineração e automotiva, com três alegaçóes cada (11\%); e indústria de petróleo e gás e alimentícia, com duas alegaçóes cada (7\%). Sete 
casos (26\%) envolvem outros segmentos industriais, tais como laminados, vestuário, embalagens, química, confecção e eletrodomésticos. Por fim, tem-se um caso referente à área de telemarketing $(4 \%)$ e um caso referente ao setor agrícola (4\%).

\section{GRÁFICO 7}

OCDE: setor das alegações de inobservância às Diretrizes submetidas em 2008 (Em \%)

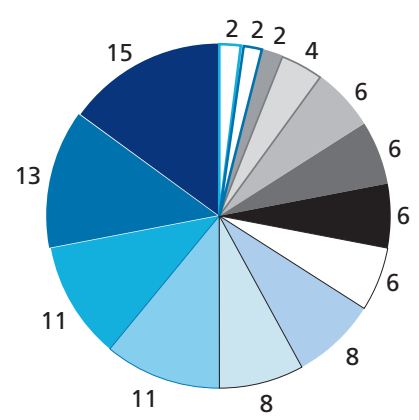

$\begin{array}{lll}\square \text { Mineração } & \square \text { Transporte } & \text { Entretenimento } \\ \square \text { Indústria } & \text { Construção } & \square \text { Atividades de serviços } \\ \square \text { Agricultura, silvicultura e pesca } & \text { Energia } & \text { administrativos e de apoio } \\ \square \text { Atividades financeiras e de seguros } & \text { Comércio atacadista e varejista } & \square \text { Hotelaria } \\ \square \text { Informação e comunicação } & \square \text { Atividades profissionais, } \\ \text { Outros serviços } & \text { científicas e técnicas } & \end{array}$

Fonte: OECD (2019).

Elaboração dos autores.

\section{GRÁFICO 8}

Brasil: setor das alegações de inobservância às Diretrizes submetidas (2003-2008) (Em \%)

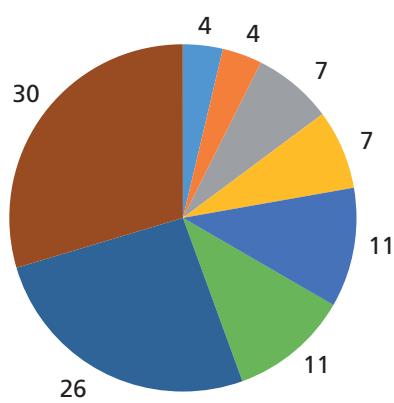

$$
\begin{array}{ll}
\text { प Serviços financeiros } & \text { Indústria alimentícia } \\
\text { Indústria: demais } & \text { Indústria de petróleo e gás } \\
\text { Indústria de mineração } & \text { Serviços de telemarketing } \\
\hline \text { Indústria automotiva } & \text { Agricultura }
\end{array}
$$

Fonte: Ministério da Economia e Fazenda. Disponível em: <http://www.fazenda.gov.br/assuntos/atuacao-internacional/ponto-de-contato-nacional/ produtos/alegacoes-de-inobservancia/banco-de-dados-das-alegacoes-de-inobservancia-das-diretrizes-da-ocde>. 


\subsection{Capítulos das Diretrizes citados nas alegações de inobservância}

O capítulo II, que versa sobre políticas gerais, foi o mais referenciado em 2018, representando 32 (63\%) alegaçóes feitas no âmbito do relatório da OCDE (gráfico 9). Isso pode ser em grande parte atribuído ao fato de que o tema da due diligence, foco de muitas das alegaçóes de inobservância recebidas pelos PCNs, estar contido nesse capítulo. O segundo capítulo mais citado foi o $\mathrm{V}$ (Emprego e Relaçóes Empresariais), seguido pelo capítulo IV (Direitos Humanos). Isso está amplamente alinhado com as tendências em 2017 e 2016. Em 2018, todos os capítulos das Diretrizes foram citados pelo menos uma vez. Cabe observar que em anos anteriores a 2016 alguns capítulos (especialmente o capítulo sobre concorrência) não foram referenciados em nenhuma submissão.

\section{GRÁFICO 9}

OCDE: alegações de inobservância às Diretrizes submetidas por capítulo (2008) (Em \%)

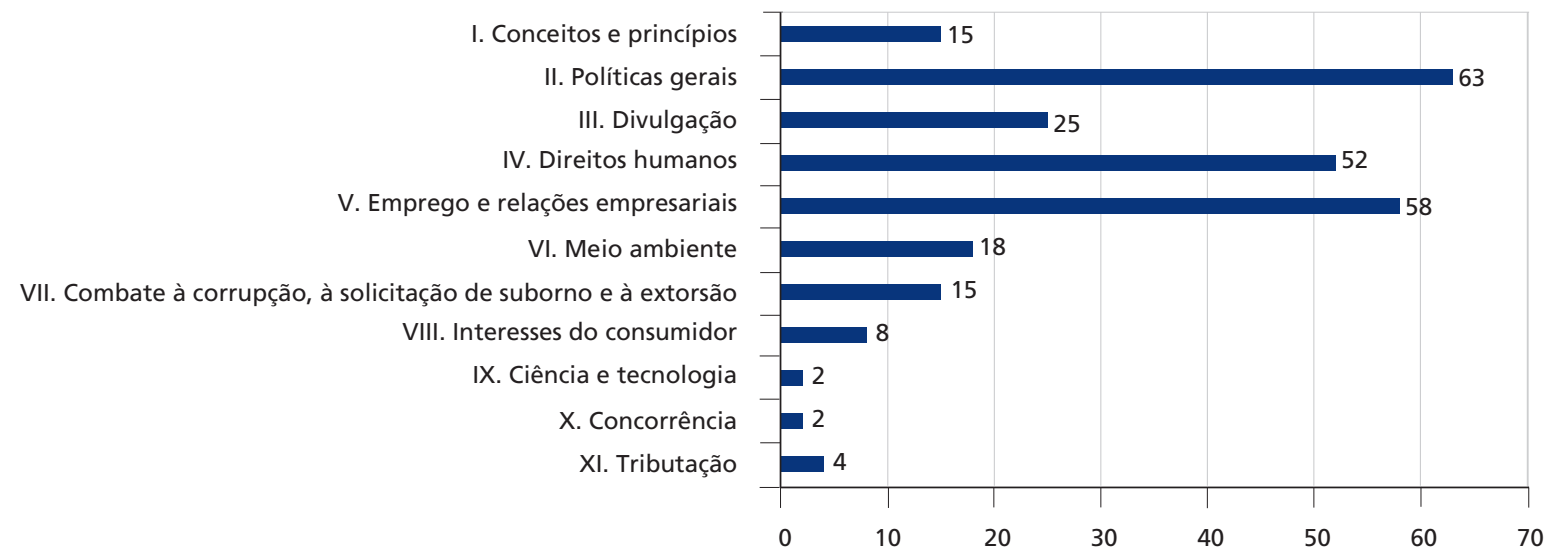

Fonte: OECD (2019).

Elaboração dos autores.

As tabulaçóes dos dados referentes ao Brasil (gráfico 10) revelam que nesses quinze anos nunca houve casos relacionados aos capítulos IX (Ciência e Tecnologia), X (Concorrência) e XI (Tributaçâo). Os três capítulos mais citados nas alegaçôes de inobservância recebidos pelo PCN brasileiro são os mesmos da OCDE, sendo o capítulo II (Políticas Gerais) o mais referenciado, sendo citado 17 vezes nas 56 citaçóes provenientes dos 27 casos (30\%), seguido pelo V (Emprego e Relaçôes Empresariais), com 16 citações (29\%), e pelo IV (Direitos Humanos), com 8 citaçóes (14\%). 


\section{GRÁFICO 10}

Brasil: alegações de inobservância às Diretrizes submetidas por capítulo (2003-2008) (Em \%)

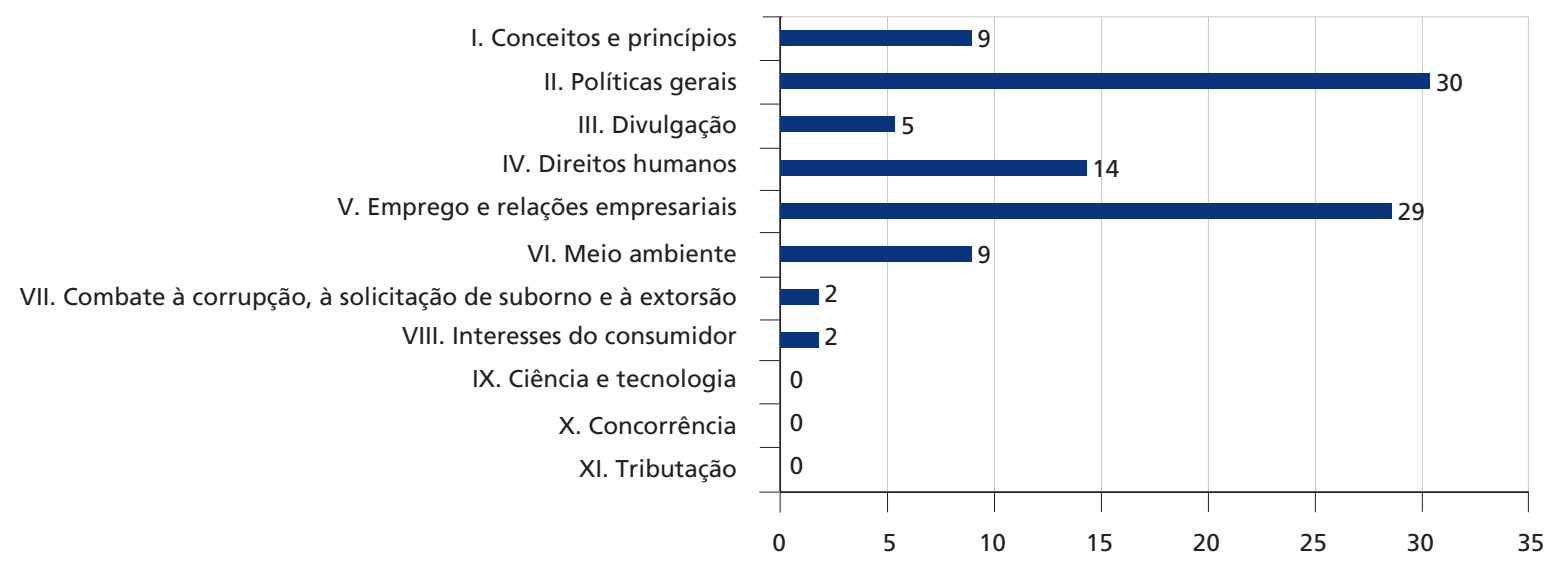

Fonte: Ministério da Economia e Fazenda. Disponível em: <http://www.fazenda.gov.br/assuntos/atuacao-internacional/ponto-de-contato-nacional/ produtos/alegacoes-de-inobservancia/banco-de-dados-das-alegacoes-de-inobservancia-das-diretrizes-da-ocde> .

\subsection{Tipo de alegante das alegações de inobservância às Diretrizes}

Por fim, o gráfico 11 mostra a distribuição em relação à natureza dos alegantes. As ONGs representam os principais usuários do sistema de PCNs da OECD, como já o era nos anos anteriores. Em 2018, sua participação no total de alegaçôes de inobservância foi de 41\% (21 envios), porcentagem ligeiramente menor em comparação com os anos anteriores, quando representaram aproximadamente $50 \%$ de todas as submissões. Os sindicatos realizaram doze submissóes (23\%) e os indivíduos, também doze (23\%).

Para o PCN brasileiro, segundo o gráfico 12, os sindicatos representam uma fatia bem maior, sendo os principais alegantes, representando 18 das 27 alegaçóes de inobservância (67\%), seguidos pelas ONGs (18\%) e indivíduos (7\%).

\section{GRÁFICO 11}

OCDE: alegante das alegações de inobservância submetidas às Diretrizes (2008) (Em \%)

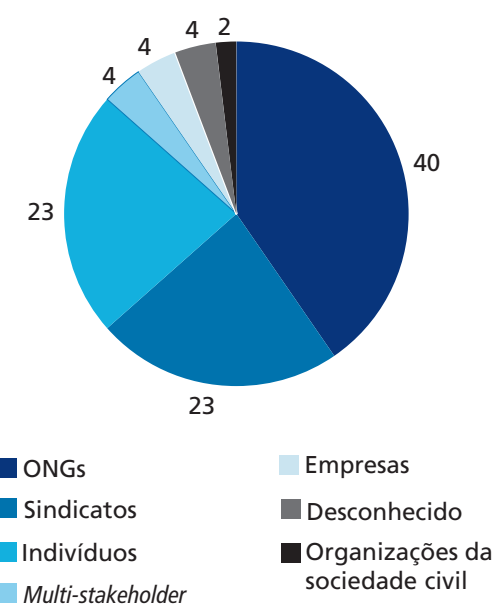




\section{GRÁFICO 12}

\section{Brasil: alegante das alegações de inobservância submetidas às Diretrizes (2003-2008)} (Em \%)

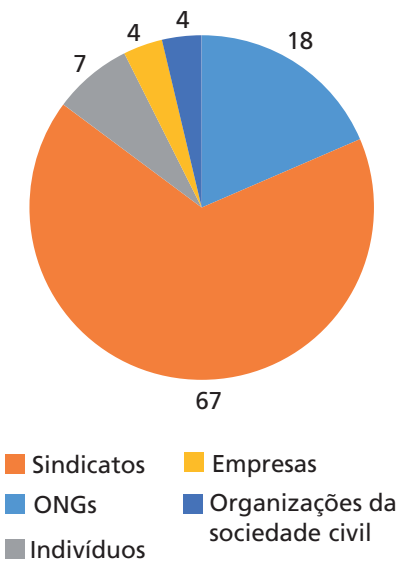

Fonte: Ministério da Economia e Fazenda. Disponível em: <http://www.fazenda.gov.br/assuntos/atuacao-internacional/ponto-de-contato-nacional/ produtos/alegacoes-de-inobservancia/banco-de-dados-das-alegacoes-de-inobservancia-das-diretrizes-da-ocde>

\section{CONCLUSÕES}

O IDE realizado pelas EMNs pode, conforme ressaltado neste artigo, trazer contribuiçóes importantes à economia e sociedade dos países hospedeiros. No entanto, este estudo destacou também a necessidade de que se considerem os eventuais danos aos países hospedeiros proporcionados pelas atividades levadas a cabo pelas corporaçóes multinacionais. Em outras palavras, é fundamental que se considere não apenas a quantidade de IDE que ingressa em um país, como também a qualidade desse investimento.

Pesquisas acadêmicas recentes indicam que a autorregulação e as iniciativas que dependem totalmente de uma abordagem voluntária para melhorar o comportamento empresarial têm grandes limitaçôes. As Diretrizes da OCDE foram criadas justamente com essa preocupação, isto é, estimular os impactos positivos e evitar/mitigar os impactos negativos aos países hospedeiros decorrentes da atuação das EMNs. Pretendeu-se, portanto, a partir dessa norma de aplicação voluntária, fortalecer a confiança mútua entre as EMNs e os governos e cidadáos dos países receptores.

Determinar o grau em que as Diretrizes influenciaram positivamente a conduta das EMNs é uma tarefa complexa, principalmente em função da dificuldade de se atribuir causalidade em uma arena que envolve marcos regulatórios e legislaçôes nacionais que recaem sobre a atuação dessas empresas. Além disso, deve-se considerar que muitas EMNs possuem suas próprias políticas nas áreas de conduta empresarial responsável e due dilligence independentemente das Diretrizes, de já terem se envolvido em alegaçóes de inobservância, ou sofrido penalidades impostas por algum PCN nacional. Ou seja, a adoção dessas políticas por parte das corporaçôes multinacionais está, em muitos casos, relacionada a objetivos como valorização da marca, maximização das vendas e consequentemente dos lucros, ao evitar que suas atividades tragam consequências negativas à sua imagem e operaçóes.

Ainda que se tenha dificuldade para o estabelecimento de relação de causalidade entre as Diretrizes e a conduta das EMNs, com base na pesquisa realizada (apoiada fundamentalmente em pesquisa bibliográfica e documental) é possível afirmar há um potencial a ser explorado nesse campo. Pode-se afirmar que tal arcabouço da OCDE pode se transformar em vetor de impactos positivos e, 
concomitantemente, mitigador dos danos causados pelas EMNs. Acredita-se que há aqui um terreno fértil, pois as Diretrizes dão ensejo à perspectiva de que os impactos negativos dessas empresas nos países hospedeiros sejam investigados e, mais importante, de reparação às partes lesadas. Assim, pode-se afirmar que as Diretrizes da $O C D E$ têm um papel único e importante para fortalecer o sistema global de governança corporativa e fornecer acesso a soluçóes para as vítimas de má conduta empresarial das EMNs.

Todavia, na prática, a partir dos dados apresentados neste estudo, os resultados alcançados até o momento estão aquém das expectativas. A natureza voluntária das Diretrizes da OCDE criou um quadro em que os governos aderentes relutam em monitorar sua observância por parte das EMNs. A promoção e o cumprimento efetivo das Diretrizes e a responsabilização das EMNs em função de eventuais danos causados aos países hospedeiros por má conduta corporativa exige que os problemas identificados em seu sistema de solução de conflitos sejam resolvidos. Caso isso não ocorra, haverá o risco de perda de credibilidade dos PCNs, limitando-os a um papel promocional ou consultivo, minando a influência e eficácia das Diretrizes.

Muitos dos estudos consultados para a elaboração deste artigo enfatizam que seria importante que os governos dos países-membros da OCDE, bem como aqueles que aderiram às Diretrizes, comprometessem-se em conferir a elas um caráter vinculativo. Ao fazer isso, eles reforçariam o papel desse documento como o único código de conduta voltado às EMNs, abrangente, endossado multilateralmente. Caso tal cenário se concretizasse, os governos nacionais estariam mais engajados em implementá-las, o que induziria tais empresas a se enquadrarem às premissas básicas das Diretrizes em termos de conduta empresarial responsável e due dilligence.

\section{REFERÊNCIAS}

ACCONCI, P. The promotion of responsible business conduct and the new text of the OECD Guidelines for Multinational Enterprises. The Journal of World Investment \& Trade, v. 2, n. 1, p. 123-149, 2001.

BACCARO, L.; MELE, V. For lack of anything better? International organizations and global corporate codes. Public Administration, v. 89, n. 2, p. 451-470, 1 jun. 2011.

BULE, T.; LESS, C. T. Promoting sustainable development through responsible business conduct. In: OECD ORGANISATION FOR ECONOMIC CO-OPERATION AND DEVELOPMENT. Development Co-operation Report 2016: the sustainable development goals as business opportunities. Paris: OECD, 2016. p. 119-136. Disponível em: <https://www.oecd-ilibrary.org/development/development-co-operationreport-2016/promoting-sustainable-development-through-responsible-business-conduct_dcr-2016-12-en>.

ČERNIČ, J. L. Corporate responsibility for human rights: a critical analysis of the OECD guidelines for multinational enterprises. Hanse Law Review, v. 4, n. 1, p. 71-100, 2008.

CHANDLER, A. D.; MAZLISH, B. (Ed.). Leviathans: multinational corporations and the new global history. Cambridge: Cambridge University Press, 2005.

COSTA, K. da. Corporate accountability in the Samarco chemical sludge disaster. Disaster Prevention and Management, v. 26, n. 5, p. 540-552, 1 jan. 2017.

FIENHOLD, L. Risks of MNCs involved in international business diplomacy: the OECD guidelines for multinational enterprises as a facilitator? In: IBA BACHELOR THESIS CONFERENCE, 3rd, 2014, Anais..., Enschede, 2014. Disponível em: <https://essay.utwente.nl/65304/>.

FOORT, S. V. The history of national contact points and the OECD Guidelines for Multinational Enterprises. Rechtsgeschichte, v. 25, n. 25, p. 195-214, 2017. 
GONZALEZ-PEREZ, M. A.; LEONARD, L. The UN Global Compact. In: JONGE; A. de; TOMASIC, R. Research handbook on transnational corporations. Cheltenham: Edwarg Elgar, 2017. p. 117-138. (Research Handbooks on Globalization and the Law Series).

NIEUWENKAMP, R. The OECD guidelines for multinational enterprises on responsible business conduct. The Dovenschmidt Quarterly, v. 4, p. 171-175, 2013.

Legislation on responsible business conduct must reinforce the wheel, not reinvent it. In: LOVE, P. (Ed.). Debate the issues: investment. Paris: OECD Publishing, 2016. p. 29-33.

Responsible FDI is no longer optional: Columbia FDI perspectives. New York: 2018. Disponível em: <http://ccsi.columbia.edu/publications/columbia-fdi- perspectives/>.

OECD - ORGANISATION FOR ECONOMIC CO-OPERATION AND DEVELOPMENT. Policy brief: The OECD Guidelines for Multinational Enterprises. Paris: OECD, 2001.

OECD Guidelines for Multinational Enterprises. Paris: OECD Publishing, 2011.

. Business and Industry Advisory Committee (BIAC). Responsible business conduct: the OECD guidelines for multinational enterprises. Paris: OECD, 2015.

. Annual Report on the OECD Guidelines for Multinational Enterprises 2018. Paris: OECD, 2019.

Financial and enterprise affairs directore: mission organisation committees activities. Paris: OECD, 2020.

Declaration on international investment and multinational enterprises. Paris: OECD, 2021.

OECD WATCH. The state of remedy under the OECD guidelines: understanding NCP cases concluded in 2018 through the lens of remedy. Paris, France: OEDCD, 2019.

Declaration on international investment and multinational enterprises: OECD/LEGAL/0144. Paris: OECD Publishing, 2021. Disponível em: <https://legalinstruments.oecd.org/en/instruments/OECDLEGAL-0144>.

OLDENZIEL; J.; WILDE-RAMSING, J.; FEENEY, P. 10 years on: assessing the contribution of the OECD Guidelines for Multinational Enterprises to responsible business conduct. Amsterdam: OECD Watch, 2010.

REINERT, K. A.; REINERT, O. T.; DEBEBE, G. The new OECD Guidelines for Multinational Enterprises: better but not enough. Development in Practice, v. 26, n. 6, p. 816-823, 2016.

ROBINSON, S. International obligations, state responsibility and judicial review under the OECD Guidelines for Multinational Enterprises regime. Utrecht Journal of International and European Law, v. 30, n. 78, p. 68-81, 2014.

RUGGIE, J. G.; NELSON, T. Human rights and the OECD Guidelines for Multinational Enterprises: normative innovations and implementation challenges. Cambridge: John F Kennedy School of Government; Havard University, 2015. (Working Paper, n. 66).

SCHAPPERT, J. Rethinking due diligence practices in the apparel supply chain. In: PATRICK LOVE (Ed.). Debate the issues: investment. Paris: OECD Publishing, 2016. p. 23-27.

THORSTENSEN, V.; CORTELLINI, A.; GULLO, M. F. A OECD como fórum de governança das empresas multinacionais. São Paulo: FGV, 2018. (Working Paper, n. 488).

TRIPODI, L. Diretrizes da OCDE para empresas multinacionais: governança corporativa, soft law e direitos humanos. Anuário do Direito Internacional, v. IX, n. 1, 2014.

UNCTAD - UNITED NATIONS CONFERENCE ON TRADE AND DEVELOPMENT. World Investment Report 2018: investment and new industrial policies. New York: United Nations, 2018. 



\title{
IMPLEMENTAÇÃO DAS DIRETRIZES DA OCDE PARA AS EMPRESAS MULTINACIONAIS NO BRASIL: AVANÇOS E DESAFIOS ${ }^{\wedge}$
}

Hevellyn Albres²

\begin{abstract}
SINOPSE
As Diretrizes da OCDE para as Empresas Multinacionais (Diretrizes) podem ser consideradas o principal instrumento internacional de conduta empresarial responsável (CER). No Brasil, sua implementação é responsabilidade de um grupo de trabalho interministerial (GTI) coordenado pelo Ministério da Economia, chamado PCN Brasil. Este artigo discute a implementação das Diretrizes por meio do PCN Brasil, indicando avanços alcançados em seus quase vinte anos de existência e desafios e oportunidades remanescentes. 0 texto é composto pelos seguintes itens: i) seção introdutória sobre o que são as Diretrizes e quais são as funções dos PCNs; ii) principais características dos PCNs e sua implementação no Brasil; e iii) desafios e oportunidades para a implementação das Diretrizes pelo PCN Brasil.
\end{abstract}

Palavras-chave: conduta empresarial responsável; Diretrizes da OCDE para as Empresas Multinacionais; Ponto de Contato Nacional; PCN Brasil.

\begin{abstract}
The Organization for Economic Co-operation and Development (OECD) Guidelines for Multinational Enterprises can be considered the main international instrument for responsible business conduct (RBC). In Brazil, its implementation is the responsibility of an inter-ministerial working group coordinated by the Ministry of Economy, called National Contact Point (NCP) Brazil. This article discusses the implementation of the Guidelines by the NCP Brazil, indicating progress achieved over its nearly twenty years of existence and the remaining challenges and opportunities. The article is structured as follows: i) an introductory section that briefly presents the main features of the Guidelines and the NCPs' roles; ii) a section presenting the key characteristics of the NCPs and their implementation in Brazil; and iii) a third section that highlights some challenges and opportunities for the implementation of the Guidelines by the NCP Brazil.
\end{abstract}

Keywords: responsible business conduct; OECD Guidelines for Multinational Enterprises; National Contact Point; NCP Brazil. JEL: F51; F53.

Artigo recebido em 28/2/2021 e aprovado em 22/3/2021.

DOl: http://dx.doi.org/10.38116/bepi29art2

\section{INTRODUÇÃO}

Conduta empresarial responsável (CER) é um tema de crescente relevância no cenário internacional, associado a discussôes como desenvolvimento sustentável, sustentabilidade e compliance, ou integridade. Podemos dizer que a CER estabelece a expectativa de que todas as empresas - independentemente de sua natureza, propriedade, porte ou setor - evitem e enderecem os impactos negativos de suas operaçóes e contribuam para o desenvolvimento sustentável dos países em que operam (OECD, 2021a).

\footnotetext{
1. As opiniões expressas neste artigo não refletem necessariamente a visão do Ministério da Economia ou do PCN Brasil.

2. Servidora do Ministério da Economia, atualmente responsável pela equipe de Coordenação e Secretaria Executiva do Ponto de Contato Nacional (PCN) Brasil para as Diretrizes da Organização para a Cooperação e o Desenvolvimento Econômico (OCDE) para as Empresas Multinacionais; mestre em políticas públicas e desenvolvimento pelo Ipea; e mestre em relações internacionais pela Universidade de Brasília (UnB).
} 
CER também envolve obrigações governamentais de incentivo e monitoramento desse comportamento, conforme estabelecem os três principais instrumentos internacionais na área: as Diretrizes da Organização para a Cooperação e o Desenvolvimento Econômico (OCDE) para Empresas Multinacionais (Diretrizes); os Princípios Orientadores da Organização das Naçôes Unidas (ONU) sobre Direitos Humanos e Empresas (Princípios Orientadores da ONU); e a Declaração Tripartite de Princípios sobre Empresas Multinacionais e Política Social da Organização Internacional do Trabalho (OIT) (Declaração Tripartite da OIT).

Entre os instrumentos internacionais para a CER, as Diretrizes destacam-se como o único código de CER abrangente e multilateralmente acordado que conta com o compromisso governamental para sua promoção (OECD, 2021b). Outra característica que as diferenciam é ter o suporte dos chamados Pontos de Contato Nacionais (PCNs), que são agências que os governos aderentes têm a obrigação de estabelecer para promover suas recomendaçóes. Eles dão suporte às partes interessadas para a implementaçáo das Diretrizes e fornecem uma plataforma de mediaçáo e conciliaçáo para a resoluçáo de questôes práticas que possam surgir sobre seu conteúdo (OECD, 2011).

No que diz respeito ao escopo, as Diretrizes são o instrumento internacional mais abrangente sobre CER, cobrindo todas as áreas-chave da responsabilidade empresarial (OECD, 2021b). Os temas cobertos, cada um em um capítulo dedicado, são: i) conceito e princípios; ii) políticas gerais; iii) divulgação; iv) direitos humanos; v) emprego e relaçóes empresariais; vi) meio ambiente; vii) combate à corrupção, à solicitação de suborno e à extorsão; viii) interesses do consumidor; ix) ciência e tecnologia; x) concorrência; e xi) tributação (OECD, 2011).

As Diretrizes refletem uma expectativa dos governos de que as empresas ajam de forma responsável. Elas fornecem princípios e padróes não vinculantes de CER para um contexto global, mas também consistentes com leis nacionais e padróes internacionais aplicáveis (OECD, 2021b). Trata-se de recomendaçóes bastante amplas direcionadas pelos governos aderentes para empresas que atuam em seus territórios ou a partir deles (OECD, 2011).

Vale mencionar que as Diretrizes são um anexo da Declaração da OCDE sobre Investimento Internacional e Empresas Multinacionais (Declaração da OCDE), um amplo compromisso político adotado em 1976 visando a facilitar o investimento direto entre os Estados-parte. Por meio dela, os países da OCDE e demais aderentes comprometem-se a buscar construir um ambiente aberto e transparente para o investimento internacional, além de encorajar as empresas multinacionais a contribuir para a obtenção de progressos econômicos e sociais (OECD, 2011).

As Diretrizes passaram por quatro revisóes $(1979,1984,2000$ e 2011) e uma atualização (1991) até hoje. Na última revisão, de 2011, o grande destaque foi a inclusáo de um capítulo para os direitos humanos, consistente com os Princípios Orientadores da ONU, que foram publicados naquele mesmo ano. Além disso, foi incluída uma abordagem nova e abrangente para a devida diligência na cadeia de suprimentos; ${ }^{3}$ houve incorporação de uma agenda proativa para auxiliar as empresas na implementação das Diretrizes; e foram realizadas atualizaçóes nos capítulos especializados e nas orientaçóes procedimentais para os PCNs

3. De acordo com a OCDE, a devida diligência baseada em riscos é um elemento-chave da CER e consiste em um processo pelo qual as empresas identificam, previnem e mitigam os impactos negativos reais e potenciais decorrentes de suas operações e prestam contas sobre como esses impactos são endereçados (OECD, 2020a). Em 2018, foi aprovado o guia da OCDE sobre devida diligência em CER, que se aplica a todas as empresas em todos os setores. Adicionalmente, foram publicados guias específicos para os setores mineral, extrativo, têxtil/calçados e agrícola, além de orientações para o setor financeiro. 
(OECD, 2011). Em 2020, iniciou-se um exercício de revisão que poderá implicar uma nova revisão das Diretrizes entre 2021 e 2022 (OECD, 2021a).

As três ferramentas principais para a implementação das Diretrizes são: i) o próprio secretariado da OCDE; ii) o Comitê de Investimentos da OCDE, especificamente por meio do grupo de trabalho (GT) de CER; e iii) os governos aderentes, com destaque para o estabelecimento dos PCNs (OECD, 2017). Os PCNs se reúnem em uma Rede dos PCNs, que alcança todos os aderentes, e também em grupos regionais, como a Rede dos PCNs da América Latina. Também merece atenção o fato de que as Diretrizes foram construídas, revisadas, e sua implementação é supervisionada não apenas por atores governamentais, mas por um conjunto de partes interessadas que representam o setor empresarial (Business at OECD - Biac), os sindicatos (Trade Union Advisory Committee - Tuac) e o terceiro setor (OECD Watch).

Dado o escopo deste trabalho, focalizamos a implementação das Diretrizes por meio dos PCNs. Realizada esta breve introdução, apresentamos, na seçáo seguinte, informaçóes fundamentais sobre a estrutura, o arranjo institucional e as funçôes dos PCNs, indicando de que modo são implementados no Brasil. Na terceira seção, analisamos alguns desafios e oportunidades para uma atuação otimizada do PCN Brasil em relação a esses elementos. Por fim, tecemos nossas consideraçóes finais.

\section{PCNs: PRINCIPAIS CARACTERÍSTICAS E IMPLEMENTAÇÃO NO BRASIL}

Os PCNs são estruturas estabelecidas pelos governos para promover as Diretrizes e lidar com casos de inobservância pelas empresas (chamados instâncias específicas), como um mecanismo de reclamação não judicial. Eles são considerados um mecanismo único de implementação de CER e têm dado suporte ao acesso à remediação em escala global (OECD, 2021a). Hoje há cinquenta PCNs estabelecidos, distribuídos entre América, Europa, Ásia, África e Oceania. ${ }^{4}$

Os PCNs foram estabelecidos na revisão de 1984 das Diretrizes, primeiramente com o papel de divulgar o instrumento e esclarecer dúvidas sobre seu conteúdo. Em 2000, houve uma significativa alteração nesse mandato, que passou a incluir o tratamento das instâncias específicas (OECD, 2020b). A partir de 2019, tem se consolidado atribuição adicional relacionada à coordenação e à coerência política em CER, além da crescente relevância dos instrumentos de devida diligência em CER (OECD, 2019).

Há um grande número de materiais disponíveis sobre os PCNs, sobretudo produzidos pela própria OCDE. Não pretendemos aqui realizar a revisão bibliográfica desse material, mas olhar de forma prática para como os PCNs estão estruturados e funcionam efetivamente. Com esse objetivo, o Questionário Anual de Reporte dos $\mathrm{PCNs}^{5}$ (Questionário) será o nosso ponto de partida para a definição das informaçóes principais a serem apresentadas e que depois darão amparo à nossa análise sobre os desafios e oportunidades do PCN Brasil.

Iniciamos esta seção tratando da estrutura e do arranjo institucional dos PCNs. Em seguida, observamos cada uma das três funçóes principais dos PCNs: informação e promoção das Diretrizes

\footnotetext{
4. A lista completa dos PCNs está disponível em: <http://mneguidelines.oecd.org/ncps/>. Dados verificados em 20 de junho de 2021.

5. Esses questionários alimentam os relatórios anuais sobre as Diretrizes, pelos quais estatísticas e tendências sobre as atividades dos PCNs são apresentadas ao Conselho da OCDE todos os anos (OECD, 2020b). Estão disponíveis na página eletrônica do PCN os Questionários de 2013 a 2020: <https://gov.br/pcn>.
} 
e instrumentos relacionados; tratamento de instâncias específicas de inobservância das Diretrizes; e coerência política em CER. Para cada ponto, realizamos uma breve introdução contextualizando o leitor e, depois, focalizamos a realidade do PCN Brasil.

\subsection{Estrutura e arranjo institucional}

Os governos aderentes têm flexibilidade na organização de seus PCNs, desde que o arranjo adotado forneça uma base eficaz para lidar com todas as questóes cobertas pelas Diretrizes e permita que o PCN atue de maneira imparcial e com accountability (OECD, 2017). Para orientar essa estruturação, as Diretrizes estabelecem critérios de visibilidade, acessibilidade, transparência e accountability a serem considerados para a garantia de equivalência funcional ${ }^{6}$ entre os PCNs (OECD, 2011).

Entre as estruturas que um PCN pode adotar, a OCDE identificou quatro padróes emergentes, além da possibilidade de um formato híbrido. A maioria dos PCNs (19) é estabelecida como agência única, e 14 deles, inclusive o Brasil, têm o formato interministerial (dois ou mais órgãos). Nove PCNs adotam o formato multistakeholder, contemplando atores do governo, organizaçóes empresariais, sindicatos e/ou organizações não governamentais (ONGs). Quatro PCNs são estruturados com base em especialistas independentes (expert-based) e dois têm formato híbrido, que combina mais de um dos anteriores (OECD, 2020b).

Independentemente do formato, a OCDE lembra lembra que é imprescindível que os PCNs tenham a confiança das partes interessadas (OECD, 2020b). Para isso, a sugestão é que esses atores sejam incluídos na estrutura dos $\mathrm{PCNs}$, o que poderia ser feito: tornando os PCNs órgáos multistakeholder; incluindo órgãos consultivos nos PCNs que têm estrutura de agência única ou interministerial; ou permitindo que as partes interessadas nomeiem os especialistas independentes, no caso dos PCNs baseados em especialistas.

No que diz respeito à estrutura e ao arranjo institucional, o Questionário focaliza: i) a estrutura, localização ${ }^{7}$ e composição do PCN; ii) a existência e forma de funcionamento de órgão(s) consultivo(s); iii) a disponibilidade e alocação dos recursos humanos e financeiros; e iv) o reporte de suas atividades (Brasil, 2020a). Em seguida, observamos a situação do PCN Brasil em relação a cada um desses pontos.

\subsubsection{Avanço da implementação no Brasil}

No que diz respeito à estrutura, localização e composição, o PCN Brasil evoluiu desde sua criação de um formato de agência única para um interministerial. Ele foi criado em 2003, por meio da Portaria do Ministério da Fazenda (MF) no 92, de 12 de maio de 2003. Naquele momento, foi estruturado como órgão de agência única, na Secretaria de Assuntos Internacionais (Sain) do MF, podendo ser auxiliado por outros órgáos governamentais (Brasil, 2003).

Aproximadamente dez anos após sua criação, e no contexto da última revisão das Diretrizes, houve uma significativa reestruturação do PCN. Em 2013, foi publicada a Portaria Interministerial no 37 , de 19 de fevereiro de 2013, que constituiu o PCN como grupo interministerial, ainda coordenado

6. As Diretrizes não trazem uma definição do que seja a equivalência funcional. 0 intuito é que todos os PCNs operem de maneira uniforme, ainda que não possuam a mesma estrutura ou regras de procedimento. De acordo com a OCDE, "para garantir que todos os PCNs operem de modo comparável, o conceito de 'equivalência funcional' é utilizado" (OECD, 2017, tradução nossa).

7. A localização consiste no secretariado no caso dos PCNs que não adotam o formato de agência única. 
e secretariado pela Sain/MF, e composto por outros dez órgãos ${ }^{8}$ (Brasil, 2013a). De acordo com o Questionário daquele ano, esperava-se que, com a participação obrigatória de outros órgãos além do então MF, houvesse maior sensação de pertencimento por essas agências governamentais e a divulgação das Diretrizes no âmbito do governo melhorasse (Brasil, 2013b).

Por fim, em 2019, acompanhando outras modificaçóes no governo federal, temos uma nova alteração de composição e localização, com a edição do Decreto no 9.874, de 27 de junho de 2019 (Brasil, 2019a). O PCN mantém a estrutura de grupo de trabalho interministerial (GTI), mas altera parte de sua composição9 e sua localização passa a estar na Secretaria Especial de Comércio Exterior e Assuntos Internacionais do Ministério da Economia (Secint/ME), mais especificamente na Secretaria Executiva da Câmara de Comércio Exterior (Camex), a cargo da Subsecretaria de Investimentos Estrangeiros (Brasil, 2019b). Pode-se considerar que o decreto representou um ganho na institucionalização do PCN, mas também houve alguns engessamentos que podem ter prejudicado sua efetividade, como discutiremos na última seção.

A evolução da composição do GTI do PCN está disponível na figura 1.

\section{FIGURA 1}

\section{Composição do PCN Brasil}

\begin{tabular}{|c|c|c|c|c|}
\hline$\check{D}_{\text {ஸे }} \quad \mathrm{MF}$ & $\sum_{i}^{m}$ & $\begin{array}{l}\text { BCB } \\
\text { CGU } \\
\text { MCTI } \\
\text { MDIC } \\
\text { MF (coordenação) } \\
\text { MJ } \\
\text { MMA } \\
\text { MPOG } \\
\text { MRE } \\
\text { MTE } \\
\text { SDH-PR }\end{array}$ & 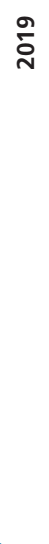 & $\begin{array}{l}\text { BCB } \\
\text { CGU } \\
\text { MJSP } \\
\text { MMA } \\
\text { MME } \\
\text { MMFDH } \\
\text { MRE } \\
\text { Secint/ME } \\
\text { (coordenação) } \\
\text { Sepec/ME } \\
\text { SEPRT/ME }\end{array}$ \\
\hline
\end{tabular}

Fonte: Brasil (2003; 2013a; 2019a).

Elaboração da autora.

Em relação à disponibilidade e à alocação dos recursos humanos e financeiros, o Brasil está entre os $53 \%$ dos PCNs que possuem funcionários trabalhando em tempo integral com o tema (OECD, 2020b). De fato, vemos um avanço substantivo de 2013, quando o PCN reporta não ter qualquer funcionário em tempo integral, para 2020, em que declara ter quatro funcionários em tempo integral

8. Os seguintes órgãos foram incluídos como membros do PCN: Banco Central do Brasil (BCB); Controladoria-Geral da União (CGU); Ministério da Ciência, Tecnologia e Inovação (MCTI); Ministério da Justiça (MJ); Ministério das Relações Exteriores (MRE); Ministério do Desenvolvimento, Indústria e Comércio Exterior (MDIC); Ministério do Meio Ambiente (MMA); Ministério do Planejamento, Orçamento e Gestão (MPOG); Ministério do Trabalho e Emprego (MTE); e Secretaria de Direitos Humanos da Presidência da República (SDH/PR) (Brasil, 2013a). Os órgãos foram escolhidos de acordo com sua expertise nos temas cobertos pelas Diretrizes (Brasil, 2013b).

9. No formato atual, a composição do PCN é a seguinte: Secint/ME; Secretaria Especial de Previdência e Trabalho (SEPRT/ME); Secretaria Especial de Produtividade, Emprego e Competitividade (Sepec/ME); Ministério da Justiça e Segurança Pública (MJSP); Ministério de Minas e Energia (MME); MMA; CGU; Ministério da Mulher, da Família e dos Direitos Humanos (MMFDH); e BCB (Brasil, 2019a). 
e mais um em tempo parcial (Brasil, 2013b; 2020a). Restam, porém, desafios, dadas as dimensões e complexidades do país e dado o aumento das funçôes dos PCNs, como exploraremos na última seção.

Quanto à existência e à forma de funcionamento de órgão(s) consultivo(s), o PCN Brasil não tem esse tipo de estrutura no momento, algo que discutiremos nos desafios e oportunidades. Por fim, quanto à accountability, reporta-se anualmente à OCDE e semestralmente ao Comitê Nacional de Investimentos (Coninv), colegiado que supervisiona as atividades do PCN (Brasil, 2020b).

\subsection{Informação e promoção das Diretrizes e instrumentos relacionados}

No que diz respeito à promoção, espera-se que os PCNs divulguem as Diretrizes para as empresas que atuem no seu país ou a partir dele, bem como para outras partes interessadas, e tirem dúvidas sobre seu conteúdo. Ademais, a partir de 2018, a OCDE vem intensificando sua atuação em devida diligência para CER. De acordo com a OCDE, os PCNs desempenham um papel-chave na promoção do uso dos guias de devida diligência, geral e setoriais (OECD, 2019a).

No eixo de promoção, o Questionário traz dois itens principais: sítio eletrônico e atividades promocionais. O sítio eletrônico deve trazer informaçóes sobre: i) as Diretrizes e o papel dos PCNs; ii) instâncias específicas; iii) atividades promocionais; e iv) contatos. Quanto às atividades promocionais, são considerados: i) plano promocional; ii) organização ou coorganizaçáo de eventos; iii) realizaçáo de apresentaçôes; iv) uso de redes sociais; v) realização de reunião multistakeholder; vi) treinamento para a comunidade empresarial; vii) promoção para comunidade empresarial, ONGs, sindicatos, governo, embaixadas no exterior, agências de promoçáo de investimento; e viii) atividades focadas nos guias de devida diligência (Brasil, 2020a).

\subsubsection{Avanço da implementação no Brasil}

Quanto às atividades promocionais, o PCN Brasil tem uma atuação bastante irregular, ainda que não esteja entre os PCNs com melhor ou pior desempenho. Em 2019, por exemplo, o PCN Brasil havia organizado nove eventos e participado de outros três organizados por parceiros. No mesmo período, o PCN França organizou 40 eventos e participou de outros 27, enquanto diversos PCNs (Egito, Estônia, Islândia, Cazaquistão, República Eslovaca) não organizaram nem participaram de qualquer evento ${ }^{10}$ (OECD, 2019).

Deficiências também aparecem ao analisar outros pontos sobre a seção de informação e promoção do Questionário. Por exemplo, a partir de 2016, o documento passou a incluir uma pergunta sobre a realização de treinamento para a comunidade empresarial sobre as Diretrizes - o PCN Brasil nunca reportou a realização de tais atividades. $\mathrm{O}$ mesmo ocorre com a realização de reunião multistakeholder ${ }^{11}$ (Brasil, 2016a; 2017; 2018; 2019b; 2020a).

A página eletrônica do $\mathrm{PCN}$ Brasil, ${ }^{12}$ por sua vez, atende à maior parte dos critérios do Questionário, tendo como exceção o item referente às atividades promocionais. Em relação a esse ponto, é esperado, por exemplo, que o PCN possua e divulgue um plano de comunicação. Ainda que o PCN Brasil

10. Para a tabela completa, consultar OECD (2020b, p. 61-62).

11. Em 2019, o PCN reporta a realização de reunião multistakeholder, mas informações a seu respeito não são documentadas nos anexos das atividades promocionais.

12. Disponível em: <https://gov.br/pen>. 
tenha reportado a existência do plano na maior parte das respostas aos Questionários durante nosso período de análise, ele não tem sido divulgado ${ }^{13}$ (Brasil, 2013b; 2014; 2015; 2017; 2018; 2020a).

\subsection{Tratamento de instâncias específicas de inobservância das Diretrizes}

Quanto à atuação como mecanismo de reclamação não judicial, o PCN fornece uma plataforma de mediação e/ou conciliação para a resolução de questôes relacionadas à inobservância das Diretrizes. De forma rápida, a OCDE prevê que o tratamento das instâncias específicas passa por três etapas e tem um prazo indicativo de doze meses para conclusão (OECD, 2011). Como veremos ao tratar dos desafios, o cumprimento desse prazo é um desafio comum na Rede dos PCNs e se aplica também ao PCN Brasil.

Uma avaliação inicial deve ser realizada em até três meses, fase em que o PCN analisa se as questóes trazidas pelo alegante merecem exame mais aprofundado e aceita o caso ou publica um comunicado explicando por que não foi aceito. A segunda etapa, com duração estimada de seis meses, é aquela em que o PCN oferece seus bons ofícios (diálogo, mediação, conciliação) ao alegante e à empresa alegada visando à resolução das questóes trazidas. Por fim, a terceira etapa, a ser realizada em até três meses, contempla a conclusão do procedimento, com a publicação de um comunicado ou relatório explicando as questóes que foram trazidas ao PCN, o suporte oferecido e os resultados alcançados (OECD, 2011).

O Questionário analisa o tema das instâncias específicas quanto a: i) regras de procedimentos para o tratamento das instâncias; ii) aspectos práticos desse tratamento, como treinamento e contratação de mediadores; e iii) reporte das instâncias (Brasil, 2020a). Nesses itens, a OCDE busca verificar se os PCNs estão agindo de acordo com os princípios orientadores para instâncias específicas: imparcialidade no tratamento, previsibilidade sobre os procedimentos e o que pode oferecer, equitabilidade entre as partes na condução do processo e operação de forma compatível com as Diretrizes (OECD, 2011).

\subsubsection{Avanço da implementação no Brasil}

Quanto às regras de procedimentos, em 2012, o PCN publicou a Resoluçáo PCN no 1, de 14 de setembro de 2012, detalhando o tratamento das instâncias específicas. Ainda que se tratasse de um documento simplificado, tal publicação é relevante, dado que é o primeiro documento desse tipo publicado pelo PCN Brasil e auxilia a atender critérios para a equivalência funcional entre os PCNs (Brasil, 2012). O normativo foi revogado pela Resoluçáo PCN no 1, de 16 de novembro de 2016, que teve como única alteração substantiva a da estrutura do PCN, que havia passado a ser constituído como GTI (Brasil, 2016a).

Finalmente, em 2020, houve uma alteração mais significativa dos procedimentos, por meio da Resolução PCN no 1, de 3 de março de 2020, que estabelece o Manual de Procedimentos para as Instâncias Especificas do Ponto de Contato Nacional. O manual traz mais detalhes sobre alguns pontos já adotados nas resoluçóes anteriores, como prazos e desistência, além de tratar de temas novos, como o acompanhamento dos compromissos estabelecidos pelas partes ou as recomendaçóes emitidas pelo PCN após a publicação da declaração final. O documento também apresenta aperfeiçoamentos em 
termos de estrutura, como a inclusão de um glossário e de um anexo com formulário para a submissão de alegação de inobservância (Brasil, 2020b).

De forma geral, os procedimentos do PCN Brasil estão alinhados com o previsto pela OCDE: possuem como fases principais a avaliação inicial (três meses), os bons ofícios (seis meses) e a conclusão (três meses), tendo como prazo indicativo a realizaçáo de todo o processo em até doze meses. Há algumas peculiaridades, como a participação de um relator na análise dos casos, uma fase adicional de admissibilidade e a não diferenciação entre comunicado e relatório, realizando a conclusão sempre por uma declaração final (Brasil, 2020b).

De maneira sintética, o processo começa com a submissão da alegação de inobservância pelo alegante. ${ }^{14}$ Em seguida, inicia-se a avaliação inicial, ${ }^{15}$ que tem três marcos importantes: uma análise de admissibilidade realizada pelo coordenador do PCN (etapa náo contemplada nos procedimentos da OCDE); a designação de um relator para a instância; e a realização da avaliaçáo inicial por esse relator, com aprovaçáo posterior pelo GTI do PCN. O relator é apontado pelo coordenador do PCN, sendo preferencialmente um representante do órgão do GTI responsável pela temática abordada na instância específica (Brasil, 2020b).

Caso a instância seja admitida e aceita, o relator poderá recomendar seu encaminhamento para os bons ofícios. ${ }^{16}$ Essa fase crucial da instância contempla uma preparação prévia pelo PCN e a oferta de bons ofícios, que deve ser aceita tanto pelo alegante quanto pela empresa alegada para ter prosseguimento. Caso a oferta seja aceita, as partes devem, ainda, aceitar o mediador ofertado pelo PCN. Este será será preferencialmente um membro do GTI, mas também pode constar de uma lista de mediadores pro bono a ser constituída por meio de um chamamento público. Em seguida, é acordado um plano de trabalho a ser seguido durante a mediação, e esta é conduzida pelo mediador (Brasil, 2020b).

A última etapa é a conclusão do procedimento de tratamento de instâncias, ${ }^{17}$ que, para o caso do PCN Brasil, sempre implica a emissão de uma declaraçáo final. ${ }^{18}$ Esse documento, que descreve o processo realizado, é elaborado pelo relator, revisado pelas partes e aprovado pelo GTI do PCN antes de sua publicação. Após a conclusão, pode haver um acompanhamento ${ }^{19}$ das iniciativas acordadas pelas partes durante a mediação ou de recomendaçóes emitidas pelo PCN na declaraçáo final (Brasil, 2020b).

Quanto aos aspectos práticos de tratamento das instâncias, o PCN Brasil confirma o recebimento das alegaçóes e solicita comentários das partes durante a conclusão dos procedimentos, quando elas são convidadas a revisar a declaração final (Brasil, 2020a). Nos itens referentes à mediação, foram raras as mediaçóes conduzidas pelo PCN até hoje e também os treinamentos realizados para

\footnotetext{
14. Ver capítulo 4 de Brasil (2020b).

15. Ver capítulo 5 de Brasil (2020b).

16. Ver capítulo 6 de Brasil (2020b).

17. Ver capítulo 7 de Brasil (2020b).

18. Para a OCDE, as instâncias podem ser encerradas por meio de um comunicado, caso a conclusão ocorra ainda durante a avaliação inicial, caso uma das partes não aceite a oferta de bons ofícios ou caso não se chegue a um acordo durante a mediação; ou de um relatório, caso as partes cheguem a um acordo (OECD, 2011).

19. Informações detalhadas disponíveis no capítulo 8 de Brasil (2020b).
} 
o aperfeiçoamento da equipe em relação ao tema (Brasil, 2013b; 2014; 2015; 2016a; 2017; 2018; 2019b; 2020a).

Por fim, quanto ao reporte das instâncias específicas, o PCN Brasil publica informaçóes sobre os procedimentos (em português e em inglês) e o andamento das instâncias em sua página eletrônica e as envia para a atualização da base de dados de instâncias específicas da OCDE (Brasil, 2020a). O PCN Brasil ultrapassa com frequência o prazo de doze meses para a conclusão das instâncias específicas (Brasil, 2021), ponto que discutiremos nos desafios. Quanto às atividades de acompanhamento das recomendaçóes realizadas pelo PCN após o fim da instância específica, eram realizadas de forma errática, mas ganharam um procedimento específico na última atualização procedimental (Brasil, 2020b).

\subsection{Coerência política em CER}

A coerência política já estava implicitamente entre as funções dos PCNs, mas vem sendo enfatizada desde 2019, quando houve o estabelecimento de um mandato no GT de CER da OCDE para o tema. Esse papel ativo na promoção da coerência política em CER é visto como parte de promoção das Diretrizes, ainda que tenha desenho próprio. Tal atuação seria importante para assegurar posiçóes governamentais efetivas e coesas diante da natureza multifacetada da CER (OECD, 2019).

De acordo com a OCDE, quando os PCNs desempenham esse papel ativo na promoção de coerência política, as abordagens governamentais para a CER são fortalecidas e a visibilidade dos PCNs como uma "autoridade em CER" em seus países é intensificada (OECD, 2019). A organização explica que os PCNs podem promover essa coerência com os entes governamentais também por meio do tratamento das instâncias específicas, ao informar outras agências sobre questôes das declaraçóes finais que sejam relevantes para os programas e as políticas das agências, algo que já está previsto nas Diretrizes (OECD, 2020b).

O Questionário passa a tratar de coerência política a partir de 2016. Os PCNs são chamados a informar sobre: i) referências às Diretrizes em legislação nacional; ii) adoção ou desenvolvimento de plano de ação nacional; iii) divulgação dos comunicados e relatórios das instâncias específicas no governo; iv) açôes sobre CER e compras públicas; e v) outros exemplos de coerência política em CER.

\subsubsection{Avanço da implementação no Brasil}

No que diz respeito a referências às Diretrizes em legislaçôes nacionais, pouco foi informado nos últimos anos, sendo os mais relevantes: o Decreto no 9.571, de 21 de novembro de 2018, que estabelece as Diretrizes Nacionais sobre Empresas e Direitos Humanos, e a Resolução Coninv no 2, de 22 de dezembro de 2020, que aprova o mandato para a elaboração do Plano de Ação em Conduta Empresarial Responsável (Brasil, 2020c).

Quanto à adoção ou ao desenvolvimento de um Plano de Ação Nacional, em alguns anos o PCN relatou que sim, em outros que não (Brasil, 2013b; 2014; 2015; 2016a; 2017; 2018; 2019b; 2020a). De fato, em 2018, o Brasil publicou o decreto citado sobre direitos humanos e empresas, mas ainda não lançou um plano de ação nacional em direitos humanos em empresas, conforme o previsto pelos Princípios Orientadores da ONU. Quanto à CER, em dezembro de 2020, foi aprovado um mandato para o desenvolvimento do Plano de Ação em CER (Pacer) pelo PCN, no âmbito do Coninv, o qual deve ser concluído até agosto de 2022 (Brasil, 2020c). 
Em relação à divulgação dos comunicados e relatórios das instâncias específicas emitidos pelo PCN para os servidores responsáveis por missóes comerciais, incentivos ao comércio e investimentos estrangeiros e compras públicas, também há divergência nos reportes entre os Questionários (Brasil, 2013b; 2014; 2015; 2016a; 2017; 2018; 2019b; 2020a). De todo modo, sabemos que parcela significativa dessas partes interessadas tem acesso a essas informaçôes por pertencer aos colegiados do PCN ou do Coninv, mas parece haver espaço para açóes adicionais.

Por fim, as compras públicas vêm sendo enfatizadas pela OCDE como um dos principais locus em que os governos podem usar sua influência para incentivar a CER. Desde 2018, há uma seção específica no Questionário sobre compras públicas, com maior ênfase em 2019 e $2020 .{ }^{20}$ Nesses dois últimos anos, o PCN Brasil reportou estar em diálogo e colaboração com os responsáveis por compras públicas no governo para impulsionar a agenda de CER, além de relatar outras açóes desenvolvidas pelos membros do GTI do PCN nessa seara (Brasil, 2018; 2019b; 2020a).

Finalizamos assim a breve análise sobre a estrutura, o arranjo institucional e as principais funçóes dos PCNs, observando o avanço da implementação no Brasil. Na seção seguinte, partimos das informaçóes apresentadas para explorar alguns dos desafios e oportunidades para a atuação do PCN Brasil.

\section{DESAFIOS E OPORTUNIDADES PARA A ATUAÇÃO DO PCN BRASIL}

Nesta seção, exploramos alguns dos desafios e oportunidades para a atuação do PCN Brasil seguindo a mesma estrutura utilizada na seçáo anterior. Iniciamos partindo da análise sobre sua estrutura e seu arranjo institucional, passamos por promoção das Diretrizes e instrumentos relacionados, pelo tratamento das instâncias específicas, e finalizamos com a coerência política em CER. Os desafios foram identificados pela análise das respostas ao Questionário em contraste com aqueles apontados pela OCDE no documento National Contact Points for Responsible Business Conduct: providing access to remedy 20 years and the road ahead (OECD, 2020b), que realiza um balanço dos vinte anos de atuação dos PCNs como mecanismo de reclamação.

\subsection{Estrutura e arranjo institucional}

\section{QUADRO 1}

Desafios e oportunidades na estrutura e no arranjo institucional do PCN Brasil

\begin{tabular}{|l|l|}
\hline \multicolumn{1}{|c|}{ Desafios } & \multicolumn{1}{c|}{ Oportunidades } \\
\hline & - Institucionalização \\
- Alta rotatividade de funcionários & - Estabelecimento de órgão consultivo \\
- Subutilização do GTI do PCN & - Treinamento \\
- Falta de recursos humanos e financeiros & - Revisãa das regras para designação de membros do GTI do PCN \\
& - Automatização do tratamento das instâncias \\
& - Otimização das parcerias \\
\hline
\end{tabular}

Elaboração da autora.

20. Questiona-se sobre menção às Diretrizes, ao PCN ou a instrumentos de devida diligência da OCDE na legislação nacional de compras públicas; consultas ao PCN pelos responsáveis por compras públicas; participação dos responsáveis por compras públicas em treinamento ou atividades de promoção; ferramentas ou atividades do PCN para dar suporte aos responsáveis por compras públicas em relação a CER e devida diligência; boas práticas envolvendo compras públicas e CER (Brasil, 2020a). 


\subsubsection{Alta rotatividade de funcionários}

No que diz respeito ao arranjo institucional do PCN, um primeiro desafio facilmente identificado é o da descontinuidade diante das alteraçóes na equipe responsável pela Coordenação e pela Secretaria Executiva do PCN, além dos membros titulares e suplentes no GTI. A OCDE aponta que alteraçóes excessivas de equipe são problemáticas, dado que drenam recursos dos PCNs por frequentes necessidades de treinamento, além de atrapalhar o relacionamento com as partes interessadas (OECD, 2020b). A organização conclui que limitar essa rotatividade pode ser um modo efetivo de reduzir atrasos no tratamento das instâncias específicas, construir expertise e ganhar confiança.

Analisando os Questionários referentes ao período de 2012 a 2020, vemos cinco alteraçóes nos responsáveis pelas respostas (em geral, o coordenador) em um período de oito anos, sem contar outras mudanças internas na equipe que não são tão facilmente identificáveis (Brasil, 2013b; 2014; 2015; 2016a; 2017; 2018; 2019b; 2020a). Ao analisar os dados de promoção e tratamento de instâncias específicas, será possível notar que há uma queda na performance do PCN a cada nova equipe responsável, demandando um tempo para reorganização, aprendizado e, muitas vezes, alteraçóes nos procedimentos.

A rotatividade de funcionários é uma questão mais ampla no governo, de difícil resolução isolada para o caso específico do PCN. Oportunidades vislumbradas seriam tornar as transiçôes, muitas vezes inevitáveis, mais brandas - por exemplo, ter treinamentos-padrão a serem realizados com novos funcionários da equipe (da Coordenação, da Secretaria Executiva, do GTI) pode ser útil. O mesmo se aplica a documentos que orientem e descrevam as rotinas de trabalho e esclareçam as funçóes entre os diferentes atores envolvidos nas atividades do PCN. Esses aperfeiçoamentos contribuiriam também para a institucionalização do PCN e para a retenção da confiança das partes interessadas.

Especificamente no que diz respeito ao relacionamento com as partes interessadas, o estabelecimento de órgão consultivo, conforme sugerido pela OCDE, pode ser útil (OECD, 2020b). Assim, o diálogo com atores estratégicos para o PCN deixaria de ocorrer de forma ad hoc e depender das pessoas que estão na gestão naquele momento, despendendo menos recursos para a reconstrução dessas parcerias a cada alteração na gestão do PCN.

\subsubsection{Subutilização do GTI}

Em relação ao formato interministerial, notamos que o GTI apresenta vantagens potenciais em relação às três funçôes principais dos PCNs:

- quanto à promoçãa, os membros do GTI podem expandir a visibilidade do PCN e promover as Diretrizes em seus temas e setores;

- quanto às instâncias específicas, garantem maior imparcialidade no tratamento e trazem sua expertise como relatores no tratamento dos casos; e

- quanto à coerência política, o GTI poderia se firmar como um dos principais locus de coordenação das políticas de CER no Brasil.

Entre os desafios que esse formato traz, a OCDE chama a atenção para a falta de uma clara definição de papéis, o que pode limitar visibilidade, acessibilidade, transparência e accountability do PCN (OECD, 2020). No Brasil, um primeiro desafio associado a essa questáo é fazer com que o 
grupo interministerial de fato contribua com as funçóes citadas, justificando o ônus administrativo que a gestão do colegiado representa para a Secretaria Executiva do PCN. Os titulares e suplentes de cada órgão não possuem dedicação exclusiva nem há uma predeterminação em decreto que associe essa representação a determinada função na instituição. Assim, aqui também a alta rotatividade pode se tornar um empecilho.

Como no caso da equipe da Coordenação e da Secretaria Executiva, acreditamos que a melhor definição de papéis e a realização de treinamentos auxiliariam a otimizar a presença do GTI no PCN. Retirar barreiras referentes à titularidade dos membros, que foram incluídas por meio do Decreto no 9.874/2019, também poderia ser útil. Dessa maneira, seria possível que os órgãos designassem técnicos especializados nos temas em discussão no $\mathrm{PCN}$ em vez de gestores de alto nível, que são alterados com mais frequência e muitas vezes não têm o interesse ou o tempo necessário para a dedicação às demandas do colegiado.

\subsubsection{Falta de recursos humanos e financeiros}

Também há desafios relevantes em relação aos recursos humanos e financeiros disponíveis para as atividades do PCN. De acordo com a OCDE, limitaçóes em relação à falta de pessoal são reportadas frequentemente nos relatórios anuais sobre os $\mathrm{PCN}$ e nos peer reviews. A organização aponta que esse é primeiro ponto a ser endereçado pelos governos para o fortalecimento de seus PCNs (OECD, 2020b).

Como vimos, o PCN Brasil tem uma equipe com dedicação exclusiva e teve aumento no número de integrantes nos últimos anos (Brasil, 2013b; 2014; 2015; 2016a; 2017; 2018; 2019b; 2020a). Porém, os desafios que veremos a seguir em relação ao extensivo trabalho necessário na promoção, ao grande número de instâncias específicas e às demandas crescentes quanto à coerência política e ao relacionamento com a própria OCDE fazem com que a equipe disponível pareça permanecer insuficiente.

Além disso, é preciso que os PCNs tenham os recursos financeiros necessários para realizar atividades promocionais customizadas e treinamentos, e lidar de modo efetivo com as instâncias específicas - por exemplo, arcando com custos de treinamento avançado em mediação ou contratação de mediadores, tradução e locomoção (OECD, 2020b). O PCN Brasil está entre os 31 PCNs que não têm um orçamento próprio (op. cit.) e reporta frequentemente nos Questionários não ter tido recursos financeiros suficientes para executar todas as atividades esperadas (Brasil, 2015; 2016a; 2017; 2018; 2019b; 2020a).

Algumas das ações enumeradas ao tratar do desafio da alta rotatividade de funcionários podem ajudar na utilização dos recursos humanos e financeiros, ao reduzir o retrabalho. Outra medida seria automatizar o máximo possível das atividades de secretariado das instâncias específicas, tendo, por exemplo, um sistema que realizasse e documentasse o recebimento e o encaminhamento de documentos, controlasse os prazos etc. No que diz respeito à promoçáo, algumas das açóes propostas no item seguinte, sobretudo quanto às parcerias, também poderiam auxiliar a potencializar o uso dos recursos disponíveis. 


\subsection{Informação e promoção das Diretrizes da OCDE e instrumentos relacionados}

\section{QUADRO 2}

Desafios e oportunidades na informação e na promoção pelo PCN Brasil

\begin{tabular}{|l|l|}
\hline \multicolumn{1}{|c|}{ Desafios } & \multicolumn{1}{c|}{ Oportunidades } \\
\hline - Baixo número de atividades de promoção & - Eventos virtuais \\
- Pouca capilaridade das atividades de promoção & - Utilização do GTI do PCN e do Coninv \\
- Deficiências na customização das atividades de promoção para perfis e setores empresariais & - Reconstrução, ampliação e utilização estratégica das parcerias \\
\hline
\end{tabular}

Elaboração da autora.

\subsubsection{Baixo número de atividades de promoção}

Um primeiro desafio é que o PCN Brasil realiza um número baixo de atividades de promoção, o que consideramos uma questão bastante grave, uma vez que essa é a função primordial dos PCNs. Conforme aponta a OCDE, a visibilidade é um dos critérios-chave dos PCNs (OECD, 2020b). Apenas criar um PCN não cumpre a obrigação governamental - espera-se que os governos façam seus PCNs visíveis, e os próprios PCNs também devem contribuir para sua visibilidade. Ademais, a limitação nas atividades de promoção reduz o conhecimento sobre o mecanismo de reclamação, diminuindo o número de instâncias específicas. Deficiências na área de promoção também impactam a visibilidade das açóes de CER no governo e no potencial de atuação do PCN como ferramenta para a coordenação e a coerência política em CER.

Nesse contexto, a OCDE trata de dois problemas principais: a realização de poucos eventos de forma geral; ou a realizaçáo de eventos que não enderecem adequadamente todas as partes interessadas relevantes (OECD, 2020b), do qual trataremos no item seguinte.

O PCN Brasil tem um número bastante irregular e, em geral, baixo de atividades promocionais (gráfico 1). De 2012 a 2014, há reporte de que o PCN organizou ou coorganizou e participou como palestrante em diversos eventos, buscando divulgar as Diretrizes no Brasil junto a um conjunto de parceiros nacionais e internacionais ${ }^{21}$ (Brasil, 2013b; 2014; 2015). Na sequência, notamos uma queda no engajamento do PCN entre 2015 e 2018 no que diz respeito a eventos e reporte de parcerias (Brasil, 2016a; 2017; 2018).

Em 2019 e 2020, assistimos a um crescimento no número de eventos, que chega a seu maior nível na série observada (Brasil, 2019b; 2020a). Os relatórios apresentados ao Coninv, no primeiro e segundo semestres de 2020, também registram uma gradual retomada da construção de parcerias com as partes interessadas ${ }^{22}$ (Brasil, 2020d; 2020e).

Uma oportunidade significativa a ser aproveitada é utilizar os eventos virtuais para a divulgação das Diretrizes para públicos mais amplos, com reduzido gasto de recursos humanos e financeiros. Uma segunda abordagem a ser considerada é buscar um melhor aproveitamento dos membros

21. Nacionais: Fórum Governamental de Responsabilidade Social, Instituto Ethos, CGU, Agência Brasileira de Promoção de Exportações e Investimentos (Apex-Brasil), agências de crédito à exportação, entre outros. Internacionais: Pontos Focais do Pacto Global da ONU, Global Reporting Initiative (GRI), International Organization for Standardization (ISO) 26000, PCNs de Reino Unido, Holanda e Noruega, entre outros.

22. Pacto Global da ONU, Laboratório de Inovação Financeira (LAB), clínicas de direitos humanos da Pontifícia Universidade Católica do Paraná (PUCPR) e do Centro Universitário de Brasília (Ceub), PCN Argentina, além das parcerias no âmbito governamental que passam a ser descritas em item dedicado à "coordenação de políticas de CER" (Brasil, 2020e). 
do GTI do PCN, e também do Coninv, como disseminadores das Diretrizes. Os Questionários apresentados à $\mathrm{OCDE}$ e relatórios ao Coninv praticamente não reportam atividades desempenhadas pelos membros. Ganhos nesse sentido seriam benéficos tanto para questóes de visibilidade quanto de coerência política em CER.

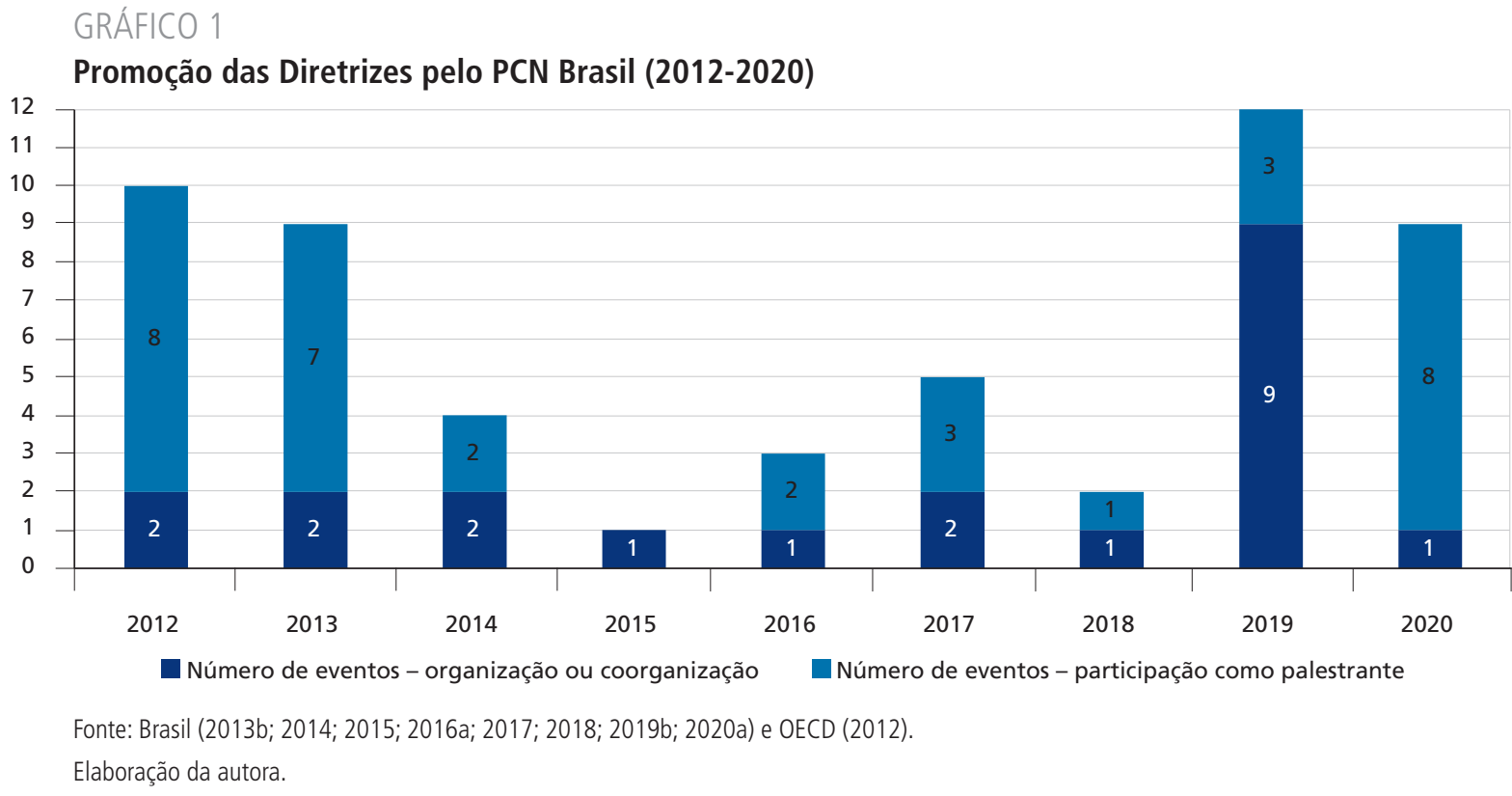

Por fim, uma terceira oportunidade que vislumbramos é retomar parcerias estratégicas com partes interessadas dentro e fora do governo brasileiro, que possam ser coorganizadoras de eventos com o PCN ou convidadas como palestrantes para eventos relacionados à CER. Ainda que a reconstrução e a manutenção das parcerias impliquem um dispêndio de recursos humanos, acreditamos que são maiores os ganhos em termos de visibilidade e confiança no PCN.

\subsubsection{Distribuição territorial das atividades de promoção}

Além do desafio em relação à quantidade de atividades promocionais, temos um adicional quanto à distribuição dessas atividades, seja territorial, por público, por setores econômicos ou temas da CER. Como vimos, a OCDE indica como um dos problemas de visibilidade dos PCNs a realização de eventos que náo enderecem adequadamente todas as partes interessadas relevantes, como é o caso de potenciais alegantes que estejam em áreas remotas (OECD, 2020b). Nesse contexto, um primeiro ponto de atenção é a grande extensão territorial do Brasil, com áreas de mais difícil acesso.

Ao analisar o registro das atividades promocionais do PCN, notamos concentraçáo em Brasília (local da estrutura física da Coordenação e da Secretaria Executiva do PCN), com São Paulo e Rio de Janeiro em seguida (Brasil, 2013b; 2014; 2015; 2016a; 2017; 2018; 2019b; 2020a; OECD, 2012). Em 2019, houve um esforço interessante de divulgação em roadshows em oito capitais brasileiras, incluindo as regióes Centro-Oeste, Nordeste, Sul e Sudeste, além de evento na regiáo Norte (Brasil, 2019b).

Em 2020, com a pandemia, os eventos passaram a ser virtuais, o que ajuda a romper as barreiras territoriais. Permanecem, porém, dificuldades para que potenciais alegantes sejam informados sobre a 
realização dos eventos e disponham das condições necessárias (como acesso à internet e equipamentos) para a participação. Uma questáo adicional é a barreira linguística, dado que muitos eventos foram realizados em línguas estrangeiras (Brasil, 2020a).

Mais uma vez, no que diz respeito à capilaridade das atividades promocionais do PCN, acreditamos que as parcerias poderiam ser um recurso valioso. $\mathrm{O} P C N$ pode se utilizar de integrantes dos colegiados governamentais e das redes com partes interessadas de que participe que tenham localização ou atuação em regiôes normalmente não cobertas por suas atividades. A Apex-Brasil, por exemplo, é membro do Coninv e já teve parcerias com o PCN no passado. Ademais, o PCN poderia acionar organizaçóes de empresas e trabalhadores nessas regióes, além de ONGs que tenham alcance nacional ou foco em regióes nas quais seja preciso ampliar sua visibilidade.

Outra oportunidade, talvez de mais fácil implementação, seria contar com o apoio da Rede de Pontos Focais do Ombudsman de Investimentos Diretos (OID). Essa estrutura se apresenta como uma "janela única de investimentos" responsável por receber consultas e questionamentos sobre matérias relacionadas a investimentos, a serem respondidos em conjunto com órgáos e entidades governamentais na esfera nacional e subnacional (Brasil, 2020f). Essa facilidade se daria porque a gestão do OID também é competência da Camex e está alocada na subsecretaria pela qual o coordenador do PCN é responsável.

\subsubsection{Customização das atividades de promoção para perfis e setores empresariais}

Indo além da dimensão territorial, no que diz respeito ao público-alvo das atividades de promoção das Diretrizes, também parece haver espaço para aperfeiçoamentos por parte do PCN Brasil. Consideramos que o principal grupo a tomar conhecimento das Diretrizes são as empresas, por isso concentramos nelas nossa análise.

Quanto ao perfil das empresas, podemos pensar em três grupos principais: multinacionais brasileiras, multinacionais estrangeiras atuando no Brasil e outras empresas nacionais. Quanto às empresas multinacionais brasileiras, virtualmente, todas as iniciativas de promoçáo comentadas atendem o público. No que diz respeito às multinacionais estrangeiras, podemos considerar que são especialmente contempladas pelos eventos organizados em parceria com atores internacionais (outros PCNs, OCDE, Uniáo Europeia etc.), sobretudo de 2012 a 2015 e em 2020 (Brasil, 2013b; 2014; 2015; 2016a; 2017; 2018; 2019b; 2020a; OECD, 2012). Ainda assim, não identificamos formatação de evento específico para esses públicos.

As empresas nacionais se apresentam como um desafio mais complexo, sobretudo para alcançar as micro, pequenas e médias empresas (MPMEs). Ainda que as Diretrizes se refiram explicitamente a empresas multinacionais, o capítulo de conceitos e princípios explica que elas trazem boas práticas recomendáveis a todas as empresas, e as empresas nacionais estão sujeitas às mesmas expectativas que as multinacionais (OECD, 2011). Além disso, as empresas nacionais fazem parte das cadeias de fornecimento de multinacionais, estando focalizadas pelo trabalho da OCDE sobre devida diligência e CER, que vimos estar ganhando peso nos últimos anos.

De acordo com dados do Instituto Brasileiro de Geografia e Estatística (IBGE) de 2015, mais de 97\% das empresas ativas no Brasil eram micro ou pequenas (Guimarães, Carvalho e Paixão, 2018). Em 2017, mais de 70\% das empresas exportadoras brasileiras eram micro (17,8\%), pequenas $(23,1 \%)$ ou médias empresas (30,2\%) (Fonseca, 2018). Mesmo com essa presença tão significativa, os dados não 
demonstram a realização de qualquer evento do PCN Brasil de 2012 a 2020 tendo como público-alvo as MPMEs (Brasil, 2013b; 2014; 2015; 2016a; 2017; 2018; 2019b; 2020a; OECD, 2012).

Outro desafio é o alcance setorial. Analisando os dados de 2012 a 2020, aparecem apenas dois eventos claramente direcionados a setores específicos: um para o setor financeiro em 2014 e um para o setor têxtil em 2015 (Brasil, 2013b; 2014; 2015; 2016a; 2017; 2018; 2019b; 2020a). Portanto, um possível aperfeiçoamento seria o PCN passar a desenvolver atividades de promoção para setores específicos - por exemplo, os mais endereçados nas instâncias específicas recebidas em determinado período ou os que são alvo de recomendaçóes ou orientaçóes particulares pela OCDE, como os guias setoriais de devida diligência em CER.

Olhando para as oportunidades, no que diz respeito às multinacionais brasileiras e estrangeiras, são um público que poderia ser explorado em parceria com as embaixadas (do Brasil no exterior e de outros países, sobretudo os aderentes às Diretrizes, no Brasil) e com PCNs estrangeiros. Quanto às empresas nacionais, mais uma vez, vemos a oportunidade de melhor utilização dos membros do próprio GTI do PCN. Um exemplo seria a CGU, que tem parceria consolidada com o Serviço Brasileiro de Apoio às Micro e Pequenas Empresas (Sebrae) para a promoção da integridade para MPMEs, agenda na qual a discussão sobre as Diretrizes poderia ser facilmente inserida.

Também enxergamos uma oportunidade de alcançar as empresas nacionais por meio de atividades e parcerias que enderecem as multinacionais, levando em consideração o papel dessas empresas de disseminar boas práticas e mitigar riscos relacionados às empresas que compóem sua cadeia de fornecimento. Essa interação poderia ser feita por meio de treinamentos para a comunidade empresarial ou reunióes multistakeholder, duas iniciativas nas quais o PCN Brasil não vem apresentando bons resultados nos Questionários e que parecem relevantes para sua visibilidade e para a eficácia da implementação das Diretrizes no país.

\subsection{Tratamento de instâncias específicas de inobservância das Diretrizes}

QUADRO 3

Desafios e oportunidades no tratamento de instâncias específicas pelo PCN Brasil

\begin{tabular}{|l|l|}
\hline \multicolumn{1}{|c|}{ Desafios } & \multicolumn{1}{c|}{ Oportunidades } \\
\hline $\begin{array}{l}\text { - Baixo número de alegações de inobservância recebidas } \\
\text { - Baixo percentual de realização de bons ofícios } \\
\text { - Dificuldade de atender aos prazos }\end{array}$ & $\begin{array}{l}\text { - Ampliação da visibilidade } \\
\text { - Aprofundamento da confiança } \\
\text { - Conscientização sobre o objetivo do mecanismo } \\
\text { - Automatização do mecanismo }\end{array}$ \\
\hline
\end{tabular}

Elaboração da autora.

\subsubsection{Baixo número de alegações de inobservância recebidas}

No que diz respeito às instâncias específicas, o primeiro desafio é o baixo número de alegaçóes de inobservância recebidas, considerando o tamanho e a inserção internacional do Brasil. Nesse contexto, apesar de o PCN Brasil ser um dos países aderentes que têm um maior número total de instâncias, ainda há o recebimento de um número baixo de alegaçóes de inobservância. Essa é uma realidade que afeta toda a Rede dos PCNs e está relacionada à acessibilidade, um dos critérios de equivalência funcional dos PCNs.

De acordo com a OCDE, dizer que os PCNs devem ser acessíveis representa que sua utilização como mecanismo de reclamação deve ser simples e não muito onerosa (OECD, 2021b). A organização 
reconhece que os PCNs vêm adotando estratégias para assegurar essa acessibilidade, mas ainda há barreiras. Um ponto de partida é que os potenciais alegantes precisam conhecer o mecanismo para que apresentem alegaçôes. Assim, as dificuldades de visibilidade sobre as quais comentamos no item anterior contribuem para a manutençáo dos casos em números relativamente baixos (OECD, 2020b).

Buscamos analisar se seria possível verificar essa relaçáo no Brasil no período analisado, de 2012 a 2020. No gráfico 1, observamos que o PCN realizou mais atividades de promoção de 2012 a 2014 e em 2019 e 2020. No gráfico 2, relacionamos essa informaçáo com a de recebimento de novas alegações de inobservância.

GRÁFICO 2

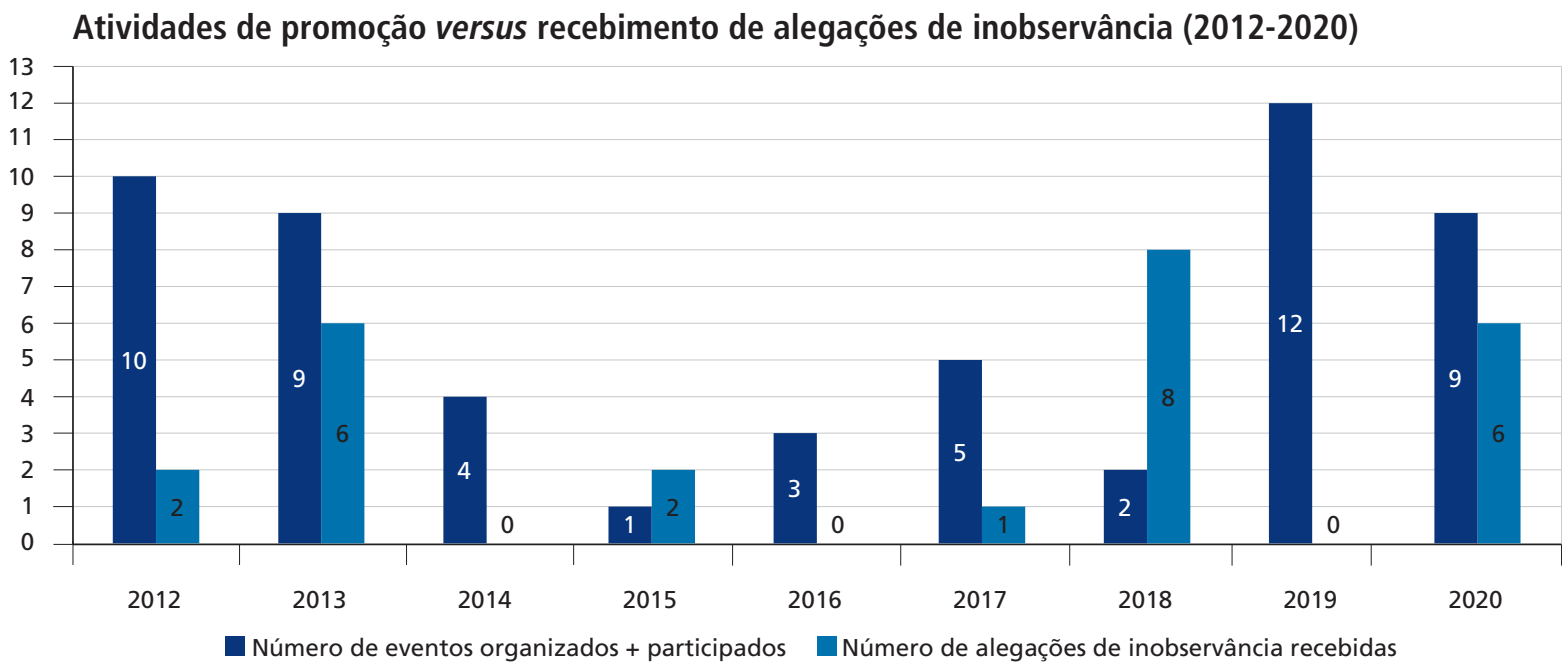

Fonte: Brasil (2013b; 2014; 2015; 2016a; 2017; 2018; 2019; 2020a; 2021) e OECD (2012).

Elaboração da autora.

Ao observar o gráfico, percebemos picos nas alegaçóes de inobservância recebidas em 2013, 2018 e 2020, com recebimento de zero a duas notificaçôes nos outros anos. Também notamos uma queda no número de atividades promocionais do PCN no período de 2014 a 2018. Porém, não foi possível identificar correlação exata entre número de atividades promocionais realizadas e alegaçóes recebidas, inclusive pelo possível efeito de que a divulgação do mecanismo motive o envio de alegação apenas em anos seguintes.

Há ainda outras questóes a serem consideradas para o recebimento de alegaçóes além da visibilidade - entre elas, podemos destacar a confiança depositada pelos alegantes no mecanismo. A queda significativa no número de alegaçóes de inobservância recebidas de sindicatos a partir de 2014 (gráfico 3) pode ser um indicativo dessa quebra de confiança. ${ }^{23}$ Por sua vez, o aumento de alegaçóes enviadas por indivíduos pode ser um bom indicativo de aumento de visibilidade do PCN e de que as regras de procedimentos estão claras o suficiente para não impor barreiras de entrada a esse público, preocupação também apontada pela $\mathrm{OCDE} .{ }^{24}$

23. Outras razões a serem consideradas são a ausência de eventos específicos endereçando esse setor nos últimos anos, a insatisfação com os resultados dos casos apresentados ao PCN, entre outras.

24. A OCDE explica que os indivíduos são o grupo mais afetado pela falta de acessibilidade dos PCNs (OECD, 2020b, p. 29). 
GRÁFICO 3

Número de instâncias específicas por alegante (2003-2020)

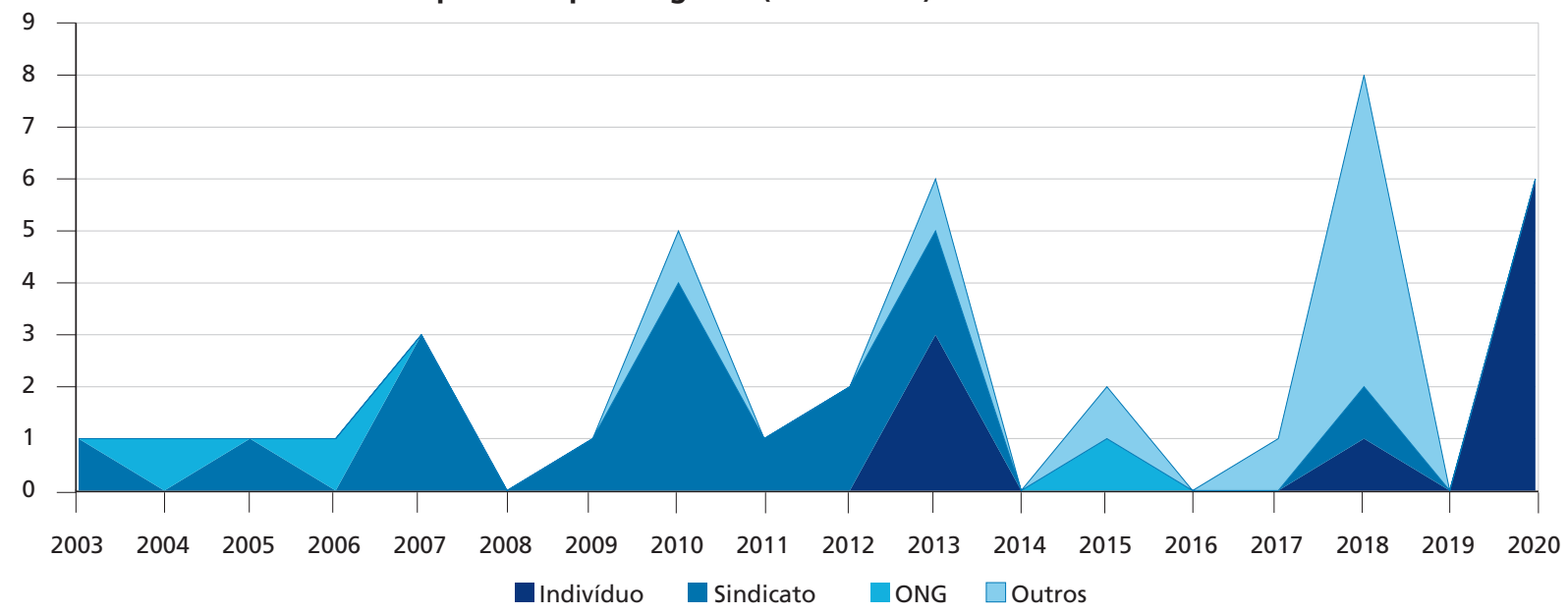

Fonte: Brasil (2021).

Elaboração da autora.

No campo das oportunidades, vislumbramos que melhorias na visibilidade do PCN atacando os desafios relacionados à promoção trarão resultados também no que diz respeito às instâncias. Quanto à confiança das partes interessadas, o PCN Brasil já vem adotando algumas medidas para endereçar a questão. Sempre há, por exemplo, um funcionário da alta administração como coordenador, que presta contas diligentemente ao Coninv, à OCDE e publica esses relatórios em sua página eletrônica, dá transparência aos procedimentos e instâncias específicas, entre outros. Porém, outras medidas, como a criação do órgão consultivo que comentamos anteriormente, pode fortalecer esse movimento.

Além disso, um contato mais direto com as partes interessadas pode auxiliar na visibilidade e na confiança, como a reunião multistakeholder mencionada no Questionário. Especificamente no que diz respeito a potenciais alegantes, acreditamos que reunióes e eventos específicos, por exemplo, com sindicatos e/ou ONGs, serão bastante úteis. Nesses encontros, o $\mathrm{PCN}$ poderia apresentar os procedimentos, tirar dúvidas sobre o funcionamento e também escutar críticas e sugestóes para o aperfeiçoamento do mecanismo.

\subsubsection{Baixo percentual de realização de bons ofícios}

Avançando nas etapas de tratamento das instâncias específicas, chegamos a um desafio que é ainda mais emblemático para o PCN Brasil: o baixo número de casos em que a etapa de bons ofícios, objetivo principal das instâncias, efetivamente ocorre. O objetivo dos PCNs é auxiliar na resolução de questôes relacionadas à implementação das Diretrizes, e eles fazem isso por meio dos bons ofícios, mais especificamente por meio da condução de procedimentos de mediação ou conciliação. Entretanto, ao olharmos os números, vemos que o PCN Brasil não é muito efetivo nesse critério.

De acordo com a OCDE, ao pensarmos na acessibilidade do mecanismo dos PCNs, devemos considerar não apenas as barreiras para a submissão da alegação de inobservância, mas também as de acesso aos bons ofícios. A organização reporta que, de 2000 a 2019, 36\% dos casos da Rede dos PCNs não passaram da avaliação inicial (OECD, 2020b). No caso do PCN Brasil, os números são bem piores: mais de 75\% dos casos foram encerrados sem a realização de bons ofícios (Brasil, 2021). 
Identificamos duas principais tendências no Brasil ao olhar esse alto percentual. A primeira é a de que o PCN oferece os bons ofícios poucas vezes, o que pode indicar dificuldades de entendimento por parte dos gestores do mecanismo de que esse é seu objetivo principal e não é necessário esgotar questóes na avaliação inicial. A segunda é a de que, quando o PCN oferta os bons ofícios, em grande parte das vezes as empresas não aceitam e os casos se encaminham para conclusão (Brasil, 2021).

Quanto às oportunidades, acreditamos que a primeira é a conscientização de que realizar os bons ofícios do PCN é o objetivo principal do mecanismo, e isso deve ser feito sempre que houver possibilidade. Esse esclarecimento pode ser realizado por meio de treinamentos à equipe do PCN, os quais estão contemplados também no eixo de estrutura e arranjo institucional. Já a aceitação da oferta de bons ofícios por parte das empresas é uma questão mais complexa, que envolve outros fatores. De todo modo, acreditamos que aperfeiçoamentos relacionados à visibilidade e à confiança no PCN podem ampliar os números de aceitação.

\subsubsection{Dificuldade de atender aos prazos}

Por fim, o último desafio que consideramos relevante discutir no âmbito das instâncias específicas é atender aos prazos indicativos com o total de doze meses para conclusão. De acordo com a OCDE, é esperado que os PCNs tratem as instâncias de modo eficiente e tempestivo. A organizaçáo reconhece que os prazos indicativos para as instâncias são relativamente curtos quando comparados aos de outros procedimentos, sobretudo os judiciais. Essa agilidade, porém, é uma das vantagens de trazer um caso ao PCN, por sua versatilidade e habilidade de agir de forma eficiente, com procedimentos simplificados (OECD, 2020b).

Dificilmente o PCN Brasil consegue concluir instâncias específicas dentro do período indicativo, sobretudo quando ocorre a etapa de bons ofícios. Os procedimentos de avaliação inicial mais demorados, que incluem a etapa não prevista pela OCDE de análise de admissibilidade, quase sempre levam mais que os três meses previstos e já inviabilizam o cumprimento do prazo total. Entretanto, a grande maioria das instâncias leva mais de dois anos para ser concluída (Brasil, 2021), o dobro do prazo total, o que indica a possível existência de pontos de retenção também em outras etapas do procedimento.

Conforme aponta a OCDE, muitos fatores impactam esses atrasos, como a complexidade dos casos, a responsividade das partes, a agenda para a realização de reuniôes, entre outros (OECD, 2020b). Ademais, dificuldades adicionais estão colocadas no contexto da pandemia. No entanto, a falta de recursos humanos para lidar com as instâncias também é um desafio considerado pela organização e importante para o contexto do Brasil, como discutimos anteriormente.

Consideramos que uma oportunidade a ser explorada, que poderia dar muito mais agilidade ao tratamento das instâncias, é a construção de um sistema automatizado que tire parte do ônus administrativo da Secretaria Executiva e agilize a comunicação entre as partes envolvidas. Entendemos que a automatizaçáo poderia trazer, ainda, benefícios adicionais em termos de previsibilidade, transparência e mesmo na confiança e credibilidade do mecanismo. 


\subsection{Coerência política em CER}

QUADRO 4

Desafios e oportunidades para coerência política em CER pelo PCN Brasil

\begin{tabular}{|l|l|}
\hline \multicolumn{1}{|c|}{ Desafios } & \multicolumn{1}{c|}{ Oportunidades } \\
\hline & - Explorar parcerias com instituições nacionais de direitos humanos (INDHs), escritórios de organizações internacionais, embaixadas, \\
- Falta de recursos humanos & $\begin{array}{l}\text { agências governamentais } \\
\text { - Utilização do GTI do PCN e do Coninv } \\
\text { - Criação de órgão multistakeholder }\end{array}$ \\
\hline
\end{tabular}

Elaboração da autora.

Por fim, no que diz respeito à coerência política, o desafio principal é que a equipe do PCN tenha recursos humanos suficientes para exercer essa função adicional. Mas talvez seja também a área em que há mais oportunidades a serem exploradas, com ganhos que podem transbordar para as funçôes de promoção (com ampliação da visibilidade do PCN) e de tratamento das instâncias específicas (com aumento da confiança no PCN e utilização dos resultados das instâncias por outras agências governamentais).

A OCDE aponta que há riscos de incoerência quando há falta de comunicação sobre as Diretrizes e o papel do PCN no âmbito do governo (OECD, 2019). Esse problema seria especialmente grave dada a coexistência de instrumentos internacionais de CER (como os Princípios Orientadores da ONU e a Declaração Tripartite da OIT), muitas vezes de responsabilidade de ministérios diferentes.

São oportunidades para a ampliação da coordenação e da coerência em CER, mas também para a promoção das Diretrizes, uma maior integração e uma melhor utilização por parte do PCN de parcerias com:

- INDHs;

- escritórios das organizaçóes internacionais, como a Rede Brasil do Pacto Global, os escritórios da ONU, da OIT e da Uniáo Europeia, o Ponto Focal da GRI no Brasil, entre outros;

- embaixadas estrangeiras no Brasil e brasileiras no exterior;

- colegiados, como o GTI do PCN e o Coninv; e

- outras agências governamentais, como as responsáveis por crédito e garantia às exportações e ao financiamento ao desenvolvimento.

Além disso, o PCN poderia considerar a criação do órgão multistakeholder, expandindo essa coordenação para atores náo governamentais.

\section{CONSIDERAÇÕES FINAIS}

Esperamos neste artigo ter fornecido ao leitor um panorama sobre o funcionamento dos PCNs, com foco no PCN Brasil. Buscamos, ainda, ter levado a reflexóes sobre alguns desafios e oportunidades relevantes para a atuação do PCN no que diz respeito a quatro áreas principais: estrutura e arranjo institucional; informaçáo e promoção; tratamento das instâncias específicas; e coerência política em 
CER. Sabemos que muitos outros temas poderiam ter sido explorados, sendo aqueles selecionados a partir da experiência da autora na equipe do PCN Brasil em dois diferentes períodos.

Nestas breves consideraçóes finais, chamamos ainda a atenção para dois movimentos já em curso e que podem impactar a implementação das Diretrizes e a atuação do PCN nas próximas décadas. O primeiro é a pandemia do coronavírus, que ainda estamos vivendo e que certamente traz, além das perdas irreparáveis, seus próprios desafios e oportunidades. O segundo é o exercício em curso de stocktaking (levantamento) das Diretrizes, que tem como objetivo verificar se elas continuam adequadas para os desafios atuais e dos próximos anos e que possivelmente levará a uma nova revisão. Nossa esperança é que as Diretrizes e o PCN reafirmem sua importância nesse novo cenário, contribuindo para a construção de um ambiente de negócios em que a conduta empresarial responsável seja o comportamento padrão.

\section{REFERÊNCIAS}

BRASIL. Ministério da Fazenda. Portaria no 92, de 12 de maio de 2003. Aprova a criação do Ponto de Contato Nacional segundo as diretrizes para as multinacionais - OCDE. Diário Oficial da Uniáo, Brasília, p. 12, 14 maio 2003. Disponível em: <https://bit.ly/3iDTPl0>. Acesso em: 25 fev. 2021.

. Resoluçáo PCN no 1 , de 14 de setembro de 2012. Dispóe sobre a atuação do Ponto de Contato Nacional. Diário Oficial da Uniáo, Brasília, 27 set. 2012.

Portaria Interministerial no 37, de 19 de fevereiro de 2013. Dispóe sobre a estrutura e organizaçáo do Ponto de Contato Nacional para as Diretrizes da Organizaçáo para Cooperaçáo e Desenvolvimento Econômico (OCDE) para as Empresas Multinacionais. Diário Oficial da Uniáo, Brasília, n. 34, p. 42, 20 fev. 2013a. Seção 1.

Ministério da Economia. OECD Guidelines for Multinational Enterprises: report to the OECD 2013. Brasília: ME, 2013b. Disponível em: <https://bit.ly/3v9WpC9>. Acesso em: 28 fev. 2021.

Ministério da Economia. Diretrizes da OCDE para as Empresas Multinacionais: relatório do Ponto de Contato Nacional do Brasil à OCDE - 2014. Brasília: ME, 2014. Disponível em: <https://bit. ly/3cxetj5>. Acesso em: 28 fev. 2021.

Ministério da Economia. Diretrizes da OCDE para as Empresas Multinacionais: relatório do Ponto de Contato Nacional do Brasil à OCDE - junho de 2014 a dezembro de 2015. Brasília: ME, 2015. Disponível em: <https://bit.ly/3xfg8BB>. Acesso em: 28 fev. 20201.

Ministério da Economia. Relatório anual do Ponto de Contacto Nacional (2016). Brasília: ME, 2016a. Disponível em <https://bit.ly/3pEXwIQ>. Acesso em: 28 fev. 2021.

Ministério da Economia. Resoluçáo PCN no 1, de 16 de novembro de 2016. Dispóe sobre a atuação do Ponto de Contato Nacional. Brasília: ME, 2016b. Disponível em: <https://bit.ly/3v68esR>. Acesso em: 28 fev. 2021.

Ministério da Economia. Relatório anual do Ponto de Contacto Nacional (2017). Brasília: ME, 2017. Disponível em: <https://bit.ly/3gsCQjf>. Acesso em: 28 fev. 2021.

. Ministério da Economia. Relatório anual do Ponto de Contacto Nacional (2018). Brasília: ME, 2018. Disponível em: <https://bit.ly/2RMdmVG>. Acesso em: 28 fev. 2021.

Decreto no 9.874, de 27 de junho de 2019. Institui grupo de trabalho interministerial denominado Ponto de Contato Nacional para a implementação das Diretrizes da Organização para Cooperação e Desenvolvimento Econômico para as Empresas Multinacionais. Diário Oficial da Uniáo, Brasília, n. 123, p. 13, 28 jun. 2019a. Seção 1. 
Ministério da Economia. Questionário do relatório anual do Ponto de Contato Nacional 2019. Brasília: ME, 2019b. Disponível em: <https://bit.ly/3womFKc>. Acesso em: 28 fev. 2021.

Ministério da Economia. National Contact Point annual reporting questionnaire (2020). Brasília: ME, 2020a. Disponível em: <https://bit.ly/2TN4nnA>. Acesso em: 28 fev. 2021.

Resolução PCN no 1, de 3 de março de 2020. Estabelece o Manual de Procedimentos para as Instâncias Específicas do Ponto de Contato Nacional. Diário Oficial da Uniáo, Brasília, n. 43, p. 15, 4 mar. 2020b. Seção 1.

Resolução Coninv no 2, de 22 de dezembro de 2020. Aprova o mandato para a elaboração do Plano de Ação em Conduta Empresarial Responsável. Diário Oficial da Uniáo, Brasília, n. 245, p. 22, 23 dez. 2020c. Seção 1.

Ministério da Economia. Relatório 1/2020 do Ponto de Contato Nacional (PCN Brasil) apresentado ao Comitê Nacional de Investimentos (Coninv) por ocasiáo da 5a reuniáo do Coninv. Brasília: ME, 2020d. Disponível em: <https://bit.ly/3cwktsy>. Acesso em: 28 fev. 2021.

Ministério da Economia. Relatório 2/2020 do Ponto de Contato Nacional (PCN Brasil) apresentado ao Comitê Nacional de Investimentos (Coninv) por ocasiáo da 6ª reuniáo do Coninv. Brasília: ME, 2020e. Disponível em: <https://bit.ly/2RFPnHw>. Acesso em: 28 fev. 2021.

. Ministério da Economia. Ombudsman de Investimentos Diretos - OID. Brasília: ME, $2020 f$. Disponível em: <http://oid.economia.gov.br/pt/menus/8>. Acesso em 17 mar. 2021.

Ministério da Economia. Instâncias específicas - alegaçóes de inobservância das diretrizes da OCDE. Brasília: ME, 11 jan. 2021. Disponível em: <https://bit.ly/2Srub8D>. Acesso em: 28 fev. 2021.

FONSECA, P. J. As micro e pequenas empresas nas exportaçóes brasileiras: 2009-2017 Brasil. Brasília: Sebrae, 2018. 132 p. Disponível em: <https://bit.ly/2SruvUT>. Acesso em: 28 fev. 2021.

GUIMARÃeS, A.; CARVALHO, K.; PAIXÃO, L. A. Micro, pequenas e médias empresas: conceitos e estatísticas. Radar, n. 55, fev. 2018. Disponível em: <https://bit.ly/2U0vDzn>. Acesso em: 28 fev. 2021.

OECD - ORGANISATION FOR ECONOMIC CO-OPERATION AND DEVELOPMENT. OECD Guidelines for Multinational Enterprises. Paris: OECD, 2011. Disponível em: <https://bit.ly/3ylzIwz>. Acesso em: 28 fev. 2021.

Annual report on the OECD Guidelines for Multinational Enterprises 2012: mediation and consensus building. Paris: OECD, 2012. Disponível em: <https://bit.ly/3jQLKdJ>. Acesso em: 28 fev. 2021.

About the OECD Guidelines for Multinational Enterprises. OECD, 2017. Disponível em: <https:// mneguidelines.oecd.org/about/>. Acesso em: 15 mar. 2021.

Action plan to strengthen National Contact Points for responsible business conduct 2019-2021. Paris: OECD, 2019. Disponível em: <https://bit.ly/3ix3J8b>. Acesso em: 28 fev. 2021.

OECD due diligence guidance for responsible business conduct. Paris: OECD, 2020a. Disponível em: <https://bit.ly/3gt5noR>. Acesso em: 28 fev. 2021.

National Contact Points for responsible business conduct: providing access to remedy 20 years and the road ahead. Paris: OECD, 2020b. Disponível em: <https://bit.ly/3xaOxS5>. Acesso em: 28 fev. 2021.

OECD responsible business conduct. OECD, 2021a. Disponível em: <http://mneguidelines.oecd. org/>. Acesso em: 28 fev. 2021.

OECD responsible business conduct. OECD Guidelines for Multinational Enterprises. OECD, 2021b. Disponível em: <http://mneguidelines.oecd.org/mneguidelines/>. Acesso em: 28 fev. 2021. 


\title{
A COMUNICAÇÃO DO PCN BRASIL: COMO AS ESTRATÉGIAS E OS INSTRUMENTOS DE COMUNICAÇÃO PODEM CONTRIBUIR PARA 0 AUMENTO DA EFICÁCIA DA AGÊNCIA?'
}

Luíza Mônica Assis da Silva²

\section{SINOPSE}

Este artigo tem como objetivo verificar se os requisitos relativos aos indicadores sobre comunicações, definidos pela Organização para a Cooperação e Desenvolvimento Econômico (OCDE) no âmbito das Diretrizes sobre Conduta Empresarial Responsável de Empresas Multinacionais, são atendidos pelo Ponto de Contato Nacional brasileiro (PCN Brasil) e analisar qualitativamente os Instrumentos de Comunicação Institucional (ICls) com vistas ao aprimoramento dos processos comunicacionais da agência. 0 referencial teórico utilizado é o da comunicação organizacional integrada, com destaque para a importância do papel dos instrumentos de comunicação pública nos processos comunicacionais. Adota-se uma metodologia qualitativa e observacional para exame dos ICls presentes na página do PCN Brasil: site, textos oficiais sobre as Diretrizes, vídeo, Manual de Procedimentos para Instâncias Específicas e relatórios. Os resultados indicam que a agência cumpre a maioria dos quesitos obrigatórios e recomendados pela OCDE. Entretanto, percebe-se a ausência de planejamento estratégico e integrado direcionado aos diferentes públicos e partes interessadas. Conclui-se que é necessário definir uma política de comunicação; dar maior autonomia à equipe técnica do PCN Brasil; aprimorar e avaliar os instrumentos de comunicação, em especial a arquitetura de informação do site; e aumentar a sinergia com as áreas de comunicação e tecnologia da informação do Ministério da Economia. Além disso, deve-se reforçar o entendimento comum do mandato do PCN Brasil junto às agências interministeriais, outros setores governamentais e partes interessadas.

Palavras-chave: Ponto de Contato Nacional; PCN Brasil; OCDE; conduta empresarial responsável; comunicação; instrumentos de comunicação; comunicação organizacional.

\begin{abstract}
The aim of this study is to check the accomplishment, by the Brazilian National Contact Point (NCP-Brazil), of the requirements related to communications indicators established by the Organisation for Economic Cooperation and Development (OECD), within the Guidelines for Responsible Business Conduct, and analyse qualitatively the Institutional Communicational Instruments (ICls), aiming at the improvement of the communicational processes of the organization. The integrated organizational communication, which emphasizes the importance of the role of mechanisms of public communication in organizational communication processes, is the theoretical background of the study, which exams NCP-Brazil's ICls, including websites, documents concerning the Guidelines, videos, Tutorial of Procedures for Specific Instances and official reports. The results indicate that the organization accomplishes most of the OECD's mandatory requisites and recommendations. However, the absence of strategic and integrated planning focused on different audiences and potential interested ones is noted. Thus, there is a need to define a communication policy; give higher autonomy to NCP-Brazil's technical staff; improve and evaluate the communication tools, particularly the website's architecture of information; and enhance the synergy with the Ministry of Economy's areas of communication and information technology. In addition, it is crucial to reinforce the common understanding of NCP-Brazil's mandate before critical bodies of the Federal Government as well as other stakeholders.
\end{abstract}

\footnotetext{
1. Este artigo foi financiado com recursos da Comissão Econômica para a América Latina e o Caribe (Cepal).
}

2. Doutora em psicologia social do trabalho e das organizações pela Universidade de Brasília (UnB) e mestre em Ciência Política pela UnB; docente e pesquisadora nas áreas de processos comunicacionais nas organizações e responsabilidade social das empresas; consultora de comunicação organizacional. 
Keywords: National Contact Point; NCP-Brazil; OECD; responsible business conduct; communication; mechanisms of communication; organizational communication.

JEL: F53; M14.

Artigo recebido em 16/4/2021 e aprovado em 26/4/2021.

DOI: http://dx.doi.org/10.38116/bepi29art3

\section{INTRODUÇÃO}

Os países que postulam ser membro da Organização para a Cooperação e Desenvolvimento Econômico (OCDE), como é o caso do Brasil, devem cumprir uma série de requisitos e, entre eles, está a adesão às Diretrizes para Empresas Multinacionais, ${ }^{3}$ que estão diretamente ligadas ao campo da Conduta Empresarial Responsável (CER) e da responsabilidade socioambiental das empresas. O documento oficial da OCDE, traduzido pelo PCN Brasil, que institui as Diretrizes as define como:

recomendaçóes dirigidas pelos Governos às empresas multinacionais. As Diretrizes visam assegurar que as operaçóes dessas empresas estejam em harmonia com as políticas governamentais, fortalecer a base da confiança mútua entre as empresas e as sociedades onde operam, ajudar a melhorar o clima do investimento estrangeiro e aumentar a contribuição das empresas multinacionais para o desenvolvimento sustentável. As Diretrizes são parte integrante da Declaração da OCDE sobre Investimento Internacional e Empresas Multinacionais, cujos outros elementos são relacionados a tratamento nacional, obrigaçóes conflitantes impostas às empresas e incentivos e desincentivos ao investimento internacional. As Diretrizes fornecem princípios e padróes voluntários para uma conduta empresarial consistente com as leis adotadas e os padrôes reconhecidos internacionalmente. No entanto, os países aderentes às Diretrizes assumem um compromisso vinculante em implementá-las em conformidade com a decisão do Conselho da OCDE sobre as Diretrizes da OCDE para as Empresas Multinacionais. Além disso, as questóes abrangidas pelas Diretrizes também podem ser objeto de legislação nacional e compromissos internacionais. ${ }^{4}$

As Diretrizes tratam de: i) conceitos e princípios; ii) políticas gerais; iii) transparência; iv) direitos humanos; v) relaçôes laborais; vi) meio ambiente; vii) combate à corrupção, à solicitação de suborno e à extorsão; viii) interesses do consumidor; ix) concorrência; e ix) tributação. São o "único código de conduta empresarial responsável acordado multilateralmente e que os governos se comprometeram a promover". ${ }^{5}$ São recomendações, ${ }^{6}$ mecanismos de soft law e tiveram sua última revisão em 2011.

Todos os 49 países aderentes, que incluem membros e não membros da OCDE, foram instados a criar as figuras dos Pontos de Contato Nacional (PCNs), que hoje atuam em mais de cem países e territórios. Sua missão é disseminar as Diretrizes junto às partes interessadas, operacionalizá-las e denunciar sua violação propondo mecanismos extrajudiciais de mediaçáo, bem como alternativas consensuais entre as partes para reparação de danos. Além disso, o trabalho dos PCNs visa contribuir

3. Doravante denominadas Diretrizes. Disponíveis em: <https://www.gov.br/produtividade-e-comercio-exterior/pt-br/assuntos/camex/pcn/ diretrizes-da-ocde-para-empresas-multinacionais $>$.

4. Disponível em: <https://www.gov.br/produtividade-e-comercio-exterior/pt-br/assuntos/camex/pcn/diretrizes-da-ocde-para-empresas-multinacionais>. 5. Disponível em: <http://mneguidelines.oecd.org/2018-Annual-Report-MNE-Guidelines-EN.pdf>.

6. Isso significa que não têm a força de um mecanismo legal, mas buscam estimular a aplicação da conduta correta, ética e que contribua para o desenvolvimento sustentável global e possível remediação de danos por parte das corporações internacionais que operam nos países aderentes e/ou a partir deles. 
para a construçáo e disseminaçáo de programas de due diligence $e^{7}$ em diferentes setores da economia, como financeiro; extrativo mineral; de vestuário e calçados; e agricultura, assim como o combate ao trabalho infantil.

Nos últimos vinte anos, os PCNs constituíram um forte instrumento para a implementação das Diretrizes e promoção de práticas de CER, bem como tiveram seu trabalho interligado a várias agências das Naçóes Unidas voltadas para a sustentabilidade e para a promoção dos direitos humanos. ${ }^{8}$ As revisóes das Diretrizes ${ }^{9}$ e Procedimentos visaram, entre outros aspectos, a construção de capacidades e de melhoria de sua efetividade, transparência, visibilidade e prestaçáo de contas. Aspectos profundamente interligados e baseados em políticas e processos de comunicação capazes de promover uma comunicação efetiva com as partes interessadas, de modo a propiciar o alcance dos objetivos organizacionais.

O PCN Brasil foi instituído em 2003 e passou por um progresso significativo ao longo de seus dezoito anos. Destacamos, especialmente, as mudanças a partir de 2019 para que pudesse acompanhar as proposiçôes da última revisão das Diretrizes. Nesse ano, o modelo, de estrutura interministerial, teve sua capacidade ampliada para atuação nas diferentes áreas das Diretrizes, bem como foi elaborado o manual de procedimentos que padroniza e esclarece sobre o rito processual para as denúncias de violaçáo das Diretrizes. Houve também aumento de seus recursos técnicos e humanos.

O PCN Brasil figura em quarto lugar no número de casos recebidos de violação das Diretrizes, ao lado dos PCNs da França e da Alemanha (OCDE, 2020b). É o PCN que mais recebe alegaçóes na América Latina. A intensa demanda e relevância desse mecanismo requer, portanto, conhecer suas fraquezas e fortalecer suas capacidades institucionais. Pesquisas indicam que empresas que foram alvo de denúncias podem ter danos em sua reputação e imagem, bem como perda no valor de suas açóes no mercado. É com base nessa premissa que o trabalho dos PCNs é apresentado como capaz de impactar favoravelmente as empresas, ao propor alternativas de remediação para os danos e minimizar os riscos por meio de due diligences. Outra importante questão nesse contexto é que o comportamento socialmente responsável, promovido pelos PCNs, pode livrar as empresas de pesadas multas e indenizaçóes.

Quando as empresas cometem graves violaçóes das Diretrizes, em geral, os fatos que sobressaem na mídia são negativos e as medidas de remediação não ganham tanto destaque. Caso o papel do PCN seja reconhecido e visível pela sociedade, pode contribuir tanto para o aumento das denúncias,

7. Mecanismo da OCDE que tem como objetivo orientar e ajudar as empresas de diferentes setores econômicos a identificar, prevenir, diminuir, contabilizar e proceder diante de impactos adversos reais e potenciais. Os guias de due diligence (financeiro, mineração, vestuário e calçados etc.) foram elaborados de forma participativa com os stakeholders das áreas e apresentam explicações em linguagem simples, além de serem ilustrativos de cases que possibilitam as empresas a lidarem com questões adversas relativas aos trabalhadores, direitos humanos, meio ambiente, suborno, consumidores e governança corporativa, que podem estar associados tanto às suas operações diretas como à sua cadeia de fornecedores, bem como a outros tipos de relações comerciais. Disponível em: <https://www.oecd.org/investment/due-diligenceguidance-for-responsible-business-conduct.htm>.

8. Disponível em: <https://www.gov.br/produtividade-e-comercio-exterior/pt-br/assuntos/camex/pcn/diretrizes-da-ocde-para-empresas-multinacionais>. 9. Desde sua criação em 1976, aconteceram cinco revisões nos anos 1979, 1984, 1991, 2000 e 2011. Essas mudanças tiveram por objetivo esclarecer e ampliá-las com novos temas/capítulos, a saber: meio ambiente, direitos humanos, direito do consumidor, combate à corrupção e compromisso da cadeia de fornecedores com a CER. As revisões também propõem procedimentos para implementação das Diretrizes para lidar com denúncias de violações (instâncias específicas) e de due diligence. Os PCNs devem elaborar o Manual de Procedimentos para Instâncias Específicas e torná-lo disponível no site da agência, bem como criar uma base de informações com os status das denúncias, declarações e declarações finais sobre o caso. Este documento deve ser disponibilizado, preferencialmente, em inglês e no idioma nacional no site da agência. Também foi criada uma base de dados aberta e informada pelos PCNs para publicizar as informações sobre as denúncias recebidas no site da OCDE. 
quanto para a divulgação dos resultados positivos das alegações e contribuir para reduzir os danos à imagem empresarial. Entretanto, quando o mecanismo das instâncias específicas ${ }^{10}$ é pouco conhecido e não tem impacto na formação da opinião pública, podemos entender que a relação entre imagem e Conduta Empresarial Responsável (CER) só é percebida em um conjunto limitado e bem específico de empresas multinacionais, de grande porte e que dependem de grupos selecionados de acionistas, investidores e consumidores.

Hoje, a maioria das empresas denunciadas não aceita participar ou dar continuidade aos bons ofícios, etapa em que o PCN busca viabilizar um acordo de consenso entre as partes para resolução das questôes relativas a instâncias específicas. Nesse sentido, ter uma política de comunicação claramente definida, desenvolver campanhas de mobilização social em prol das Diretrizes, da CER e dos temas de due diligence são fundamentais para o cumprimento da missão do PCN.

Nos últimos anos, o mandato dos PCNs tem sido substancialmente ampliado, com as recomendaçóes de follow up dos acordos das declaraçóes finais e a missão de promover a CER junto a agências governamentais, empresas estatais e nas compras públicas. Dessa maneira, é fundamental que o PCN nacional seja percebido como credível, identificado como um importante ator na promoção da CER.

A comunicação nas organizações tem como principal função melhorar, de modo integrado, as relaçôes comunicativas que impactam a eficácia e a eficiência das organizaçóes junto aos seus públicos internos (funcionários de um setor e demais áreas) e diversificados públicos externos com os quais se relaciona. Além disso, colabora de modo essencial para a formação de uma imagem positiva, credibilidade e confiança de que as organizaçôes estão cumprindo a missão e desempenhando os papéis para os quais foram criadas, bem como para sua influência político-social (Kunsch, 2003).

Seguindo Duarte (2009), a análise dos instrumentos de comunicação institucionais (ICI) - sites, documentos públicos, eventos, cartazes, folders, fyers, bases de dados, clipping da imprensa, boletins de notícias, relatórios, discursos etc. - por meio dos quais as organizaçôes falam sobre si mesmas e sobre as açóes que desempenham é extremamente importante, uma vez que permite identificar e, por vezes, mensurar e auditar os aspectos de transparência, participaçáo, accountability, imagem e grau de confiança dos PCNs em sua missão de promover e zelar pelo cumprimento das Diretrizes. Tais instrumentos refletem também o grau de institucionalização de uma agência, sua trajetória de desenvolvimento, bem como a memória de suas atividades.

Os ICIs contribuem sobremaneira para a função de mobilização social para a causa da CER. Sua função maior é tornar os PCNs conhecidos e credíveis pelos stakeholders. Sáo veículos de disseminaçáo das Diretrizes, podendo propiciar o aumento da procura e o acompanhamento das alegaçóes de violaçáo.

Uma das formas de analisar a imagem e a identidade de uma organizaçáo é por meio das mensagens que veicula, uma vez que estas são importantes artefatos da cultura organizacional tangível e intangível. Pelos ICIs também podemos inferir e apreender a recepção dos conteúdos das mensagens

10. Na revisão das Diretrizes de 2000, ocorreu a definição de que os PCNs teriam em seu mandato um mecanismo não judicial para receber e mediar reclamações de violação da Diretrizes pelas empresas multinacionais, denominado alegação de inobservância ou instância específica. Desde então, essa é uma de suas principais funções, ou seja, receber e lidar com denúncias encaminhadas por indivíduos e/ou uma variedade de tipos de organizações (empresariais, representativas de empresas, sindicatos de trabalhadores, organizações não governamentais etc.), que são denominados alegantes, em contraposição às multinacionais denunciadas (alegadas). 
pelos públicos e se sua linguagem está adequada ao meio utilizado. ${ }^{11}$ As ferramentas da comunicação organizacional podem ser, portanto, fundamentais no engajamento das partes e compreensão do complexo de mediação e reparação e que requer um alto grau de compreensão e convencimento dos custos e benefícios das partes envolvidas. Nessa direção, estratégias comunicativas podem ser utilizadas no convencimento das empresas a participarem do processo sem o temor de danos reputacionais e confiança em sua confidencialidade, imparcialidade, isonomia, boa-fé, autonomia das partes e transparência. A comunicação institucional efetiva pode fazer com que as partes percebam que o principal papel do PCN é o de promover as Diretrizes e a CER em ambiente de negócios de mútua aprendizagem e corresponsabilidade entre os atores e não enxergar a agência como mais uma instância de sanção e punições às empresas denunciadas. Além disso, a comunicação estratégica e integrada pode dar publicidade e visibilidade ao processo de aprendizagem conjunta das partes nos processos e aos resultados dos acordos de mediação, bem como predispor as partes a compreender e aceitar um mecanismo extrajudicial, com menos formalidades e fundado na justiça restaurativa e na mediação de conflitos, ${ }^{12}$ propiciando que a resolução das denúncias ocorra de maneira dialogada e consensual entre as partes e náo no acirramento do conflito. ${ }^{13}$

O processo de mediação almejado pelos PCNs coloca as partes não numa relação de antítese, mas de solução de reparação conciliada, sustentável e baseada na comunicação, transparência, boa-fé e diálogo. Trata-se de um processo diferente das disputas judiciais tradicionalmente travadas pelas empresas com sindicatos, organizaçóes da sociedade civil e indivíduos quando elas causam danos sociais, ambientais e desrespeitam direitos individuais e coletivos. Nessa sistemática, estratégias comunicacionais eficazes podem vir a facilitar a promoção do diálogo e da compreensibilidade do processo, aumentando a adesão das partes (alegantes e alegadas) na busca de soluçóes e reduzir os prazos de resolução das alegaçóes.

Podemos inferir que o uso adequado de estratégias comunicativas poderia contribuir para minimizar um dos mais graves problemas do mecanismo: a falta de engajamento das companhias. De acordo com os dados informados pelos 49 PCNs em 2019, a porcentagem de instâncias específicas concluídas com acordo foi de apenas 33\%, sendo que 7\% das companhias aceitaram participar mas não chegaram a um acordo. A maioria das empresas denunciadas, $53 \%$, se recusaram a participar do processo e outros $7 \%$ chegaram a acordos em processos paralelos ao conduzido pelo PCN. Somente dois dos quinze casos concluídos em 2019 o foram no prazo de um ano previsto para a resoluçáo, sendo que um dos casos levou oito anos para ser finalizado (OECD, 2020a).

A análise dos ICIs e articulação com stakeholders estão previstas como elementos da revisão por pares (peer review) ${ }^{14}$ do PCN e reportada em seus relatórios como um dos elementos-chave de

11. Recomenda-se que as pesquisas de recepção sejam multimetodológicas e utilizadas outras técnicas como grupos focais, pesquisas de opinião junto aos públicos e análise de conteúdo das informações veiculadas pela mídia.

12. Trata-se do art. 2o da Lei no 13.140/2015, que dispõe sobre a mediação entre particulares como meio de solução de controvérsias e sobre a autocomposição de conflitos no âmbito da administração pública.

13. As medidas autorizativas de comunicação que a OCDE preconiza são: propor estratégias de comunicação e promocionais para disseminação das Diretrizes e mecanismos de due diligence; ter visibilidade, transparência e confiança dos stakeholders, bem como manter a confidencialidade quando se fizer necessário; reportar e prestar contas de suas atividades para seus governos e partes interessadas; e buscar e manter relacionamentos com as partes interessadas e parceiros estratégicos.

14. A revisão por pares é um processo bastante completo de avaliação a que todos os países-membros e aderentes devem se submeter até 2023. Os resultados das discussões e da revisão são apresentados em um relatório público nas bases de dados da OCDE, assim como as respostas dos PCNs dos países que foram objeto da revisão, caso desejem. 0 objetivo é verificar in loco e por meio da aprendizagem conjunta e da troca de experiências entre os pares se o PCN funciona de modo visível, acessível, transparente e responsável. Verifica-se também se as instâncias e procedimentos possibilitam lidar com as alegações de maneira imparcial, previsível, equitativa e compatível com as Diretrizes. 
avaliação e pontos a serem melhorados. A OECD Watch, organização não governamental (ONG) que representa a sociedade civil no acompanhamento das multinacionais, também avalia os PCNs com base em uma série de indicadores relacionados aos instrumentos de comunicação, entre outros. ${ }^{15}$

As estratégias, processos e instrumentos de comunicação contribuem sobremaneira para viabilizar os critérios nucleares do mandato dos PCNs - visibilidade, acessibilidade, transparência e accountability. Estão também diretamente ligados à promoção das Diretrizes junto às partes interessadas, e fazem parte da maioria dos elementos-chave que a OCDE considera para a análise do desempenho dos PCNs. ${ }^{16}$ Além disso, a análise dos processos comunicacionais (perspectivas e discursos das partes; e diálogo com stakeholders da equipe técnica e órgãos consultivos, seja na mídia, nas reunióes ou em encontros anuais) possibilita compreender e estabelecer diagnósticos precisos dos temas da revisão por pares, a saber: arranjos institucionais, promoção das Diretrizes e instância específicas.

Por ser um órgáo interministerial do governo brasileiro e estar sediado no Ministério da Economia, o PCN Brasil deve atender aos requisitos da comunicaçáo pública, especialmente à Lei de Acesso à Informação, ${ }^{17}$ paralelamente à garantia de confidencialidade. A comunicação pública tem, no caso do PCN, o papel de mediação estratégica entre as instituiçóes públicas, privadas, nacionais, internacionais, multilaterais, da sociedade civil e cidadãos. Seu pressuposto principal deve ser a transparência, a publicização e "deve ser pensada como um processo de interação no qual prevalecem a expressão, a interpretação e o diálogo" (Matos, 2011, p. 45).

Diante do exposto, podemos afirmar que o planejamento e uso estratégico e integrado da comunicação são fatores-chave para o desenvolvimento de alianças com os parceiros sociais, bem como para o desenvolvimento e manutenção das relações com os stakeholders (OECD, 2019) e a visibilidade e confiança no trabalho desenvolvido pelo PCN Brasil. Adicionalmente, lembramos que, com o advento dos meios e redes digitais, os instrumentos de comunicação foram potencializados de modo a atingir uma infinidade de públicos, além de serem caracterizados pela interação e dialogicidade, bem como de múltiplos recursos de linguagem.

Desse modo, o objetivo deste artigo é aferir, por meio de análises qualitativas, em que medida os ICIs do PCN Brasil estão em conformidade com os procedimentos vinculativos e autorizativos da OCDE e como a comunicação institucional pode ser incrementada de modo a promover uma maior visibilidade, acessibilidade, transparência e accountability das atividades da agência, bem como fortalecer a efetividade de suas açóes de promoção da CER.

\section{METODOLOGIA DE ANÁLISE DOS ICls}

Primeiramente, são apresentados os indicadores de comunicação do PCN Brasil extraídos da pesquisa Avaliações do PCN da OECD Watch. Na sequência, visando avaliar os ICIs do PCN Brasil, efetua-se análise documental qualitativa do conteúdo e design relativos aos documentos disponíveis no

\footnotetext{
15. Disponivel em: <https://www.oecdwatch.org/indicator/>.

16. Entre eles estão: site, regras de procedimento on-line, plano promocional e organização de eventos. Todos demandam uma estreita relação com assessorias de comunicação e atividades de interface com a comunicação organizacional, relações públicas, assessoria de imprensa, publicidade e marketing.

17. Lei Federal no 12.527/2011, que estabelece que as informações referentes à atividade do Estado são públicas, exceto aquelas expressas em legislação específica.
} 
site do PCN Brasil. ${ }^{18}$ Foram analisados os seguintes instrumentos: site, vídeo institucional, manual de procedimentos e relatórios anuais. Além disso, a pesquisa valeu-se de uma entrevista com um membro da equipe técnica do PCN Brasil, em dezembro de 2020, na qual a comunicação institucional foi um tópico destacado.

\section{RESULTADOS E DISCUSSÃO}

\subsection{Avaliação do PCN Brasil pela OECD Watch}

A pesquisa da OECD Watch avaliou 48 PCNs com base em um conjunto de quarenta indicadores-chave de desempenho sobre organizaçáo e governança; procedimentos de tratamento das alegaçôes de inobservância das Diretrizes; e comunicaçóes. Para fins desta pesquisa, nos detemos nos indicadores relativos às comunicaçôes.

O quadro 1 mostra os dezenove indicadores de comunicação, a avaliação da OCDE Watch em relação ao atendimento dos requisitos pelo Brasil e pelos $48 \mathrm{PCN}$ s avaliados na pesquisa. Observa-se que, em relação aos nove requisitos obrigatórios sobre as comunicaçóes, o PCN Brasil apenas não cumpre os que estấo relacionados a due diligence e apresentação das declaraçóes finais na página institucional. Sugerimos que o destaque sobre due diligence seja observado, uma vez que o Brasil tem recebido várias reclamaçóes em áreas cobertas pelos guias - que são fruto de um processo participativo entre as partes interessadas, governos, OCDE e têm reconhecida qualidade técnica. Lembramos que os setores econômicos que receberam o maior número de denúncias no Brasil são: setor manufatureiro (10); setor financeiro e de atividades de seguro (8); e mineração (7). Dessa maneira, tornar esses documentos mais acessíveis e inteligíveis poderia incentivar as empresas de diferentes portes que atuam nesses setores a estarem mais atentas aos riscos, prevenção de danos e temas de CER específicas para esses grupos.

Em relação às declaraçôes finais, o PCN Brasil tomou a decisão de publicar todas as alegaçóes concluídas como declaraçóes. Até o momento de encerramento da coleta de dados deste estudo, elas não estavam no site por problemas de migração de informaçốes que serão discutidos adiante.

Quanto aos indicadores recomendados, observamos que a agência precisa melhorar a divulgaçáo e os resultados dos eventos organizados e coorganizados, bem como ampliar a participação de todos os grupos das partes interessadas. A publicização do orçamento é uma questão mais complexa por tratar-se de uma agência interministerial, e os custos materiais e humanos do secretariado serem de responsabilidade do Ministério da Economia.

Os requisitos cumpridos parcialmente (3) referem-se à apresentação mais detalhada e abrangente das Diretrizes, das funçóes do PCN e dos eventos promocionais. Sáo tópicos relativamente simples de resolver, mas que dependem de mudanças na arquitetura do site, tradução de documentos e maior autonomia da equipe técnica para inserção e atualização de informaçôes. A seguir apresentamos os resultados das análises qualitativas dos ICIs do PCN Brasil. 
QUADRO 1

Avaliação dos indicadores de comunicação do PCN Brasil pela OECD Watch

\begin{tabular}{|c|c|c|c|c|}
\hline Indicador & Status de implementação & Obrigatório & Recomendado & $\begin{array}{l}\text { Número de PCNs que } \\
\text { atendem ao indicador }\end{array}$ \\
\hline 1.Informações de contato do PCN. & Sim. & $x$ & & 43 \\
\hline 2.Diretrizes na língua nacional e em inglês. & Sim. & $x$ & & 41 \\
\hline 3. Apresenta as funções do PCN. & $\begin{array}{l}\text { Parcial, }{ }^{1} \text { uma vez que descreve sinteticamente as } \\
\text { funções. Destaca o tratamento das reclamações, mas } \\
\text { não as ações de promoção das Diretrizes. }\end{array}$ & & $x$ & 40 \\
\hline 4. Instruções para preenchimento das reclamações. & Sim, ${ }^{1}$ estão disponíveis em inglês e português. & & $x$ & 38 \\
\hline $\begin{array}{l}\text { 5. Apresenta as regras de procedimento no idioma nacional } \\
\text { e em inglês. }\end{array}$ & Sim. ${ }^{1}$ & $\mathrm{x}$ & & 33 \\
\hline 6. 0 site é multilíngue. & $\begin{array}{l}\text { Parcial, }{ }^{1} \text { os principais documentos em relação às } \\
\text { alegações estão traduzidos. }\end{array}$ & $x$ & & 32 \\
\hline 7. Reporta as atividades ao governo e/ou parlamento. & Sim. & & $x$ & 30 \\
\hline 8. Descreve os eventos promocionais. & Parcial, ${ }^{1}$ mas apenas no relatório da OCDE. & & $x$ & 29 \\
\hline 9. Relatório anual submetido à OCDE e publicado no site. & Sim. & $x$ & & 27 \\
\hline 10. Desenvolveu materiais promocionais. & $\begin{array}{l}\text { Sim: }{ }^{1} \text { site, vídeo e material impresso (não estão } \\
\text { disponíveis na página). }\end{array}$ & $\mathrm{x}$ & & 26 \\
\hline $\begin{array}{l}\text { 11. Organizou e/ou coorganizou eventos promocionais com } \\
\text { todos os grupos das partes interessadas. }\end{array}$ & $\begin{array}{l}\text { Não. Organizou e coorganizou eventos, mas sem a } \\
\text { participação de todos os grupos de partes interessadas. }\end{array}$ & & $x$ & 29 \\
\hline 12. 0 site mostra todos os textos de due diligence da OCDE. & $\begin{array}{l}\text { Não, }{ }^{1} \text { o link para a OCDE e a tradução para o português } \\
\text { não estão disponíveis. }\end{array}$ & $\mathrm{x}$ & & 25 \\
\hline $\begin{array}{l}\text { 13. Realização de atividades no exterior para promoção } \\
\text { das Diretrizes. }\end{array}$ & $\begin{array}{l}\text { Sim, as atividades são descritas nos relatórios } \\
\text { submetidos à OCDE. }\end{array}$ & & $x$ & 24 \\
\hline $\begin{array}{l}\text { 14. } 0 \text { site mostra uma declaração final abrangente para cada } \\
\text { alegação que chega a esta fase. }\end{array}$ & $\begin{array}{l}\text { Não, ' são apresentados apenas os resumos das } \\
\text { instâncias específicas. }\end{array}$ & $\mathrm{x}$ & & 24 \\
\hline 15. Possui banco de dados de reclamações publicado no site. & Sim. & & $x$ & 23 \\
\hline 16.0 site mostra uma explicação abrangente das Diretrizes. & $\begin{array}{l}\text { Parcial, }{ }^{1} \text { o documento sobre as Diretrizes está disponível } \\
\text { em inglês e português (breve explicação). Também } \\
\text { foram criados folhetos e vídeo. }\end{array}$ & & $\mathrm{x}$ & 20 \\
\hline 17. Apresenta as avaliações iniciais. & Sim. ${ }^{1}$ & $x$ & & 6 \\
\hline 18. Divulga o plano promocional delineando atividades futuras. & Não. & & $x$ & 6 \\
\hline 19. 0 site informa o orçamento e fluxos de gastos do PCN. & Não. & & $x$ & 2 \\
\hline
\end{tabular}

Fonte: OECD Watch. Disponivel em: <https://www.oecdwatch.org/indicator/>.

Elaboração da autora.

Nota: ${ }^{1}$ Indicadores revistos e atualizados pela autora, com base na observação da página do PCN Brasil no período de dezembro de 2020 a março de 2021.

\subsubsection{Site}

Os portais e sites da internet são parte das tecnologias digitais de informação e comunicação, uma forma de transmissão em rede que tem como características principais possibilidade de interatividade e diversidade de elementos numa mesma mensagem (textos, imagens, sons e recursos de hipermídia). Os sites institucionais têm a função de apresentar instituições para seus diversos públicos, fazendo uso da arquitetura da informação, design e conteúdo como ferramentas de informação e comunicação (Côrrea, 2008). A página do PCN Brasil é a principal ferramenta de acesso a informaçóes sobre o órgão e para apresentação de alegaçóes de inobservância das Diretrizes. Encontra-se no portal do governo federal, mais precisamente no Ministério da Economia, na seçáo relacionada à Câmara de Comércio Exterior (CAMEX).

As palavras-chave utilizadas para acesso à página devem ser Ponto de Contato Nacional ou PCN Brasil, do contrário, aparecem informaçôes sobre os Parâmetros Curriculares Nacionais, termo mais conhecido, porém da área de educação. A página apresenta alta velocidade de carregamento 
(até cinco segundos). O site adota o padrão do governo federal e não é atualizado diretamente pela equipe do PCN. O design apresenta boa tipologia, a cor predominante é o cinza e o destaque colorido é dado ao logotipo do governo federal, com as cores do país. Não apresenta gráficos ou ilustraçôes. A navegação é intuitiva e simples, por meio da barra de rolagem. Existe também um mecanismo de busca no site (figura 1).

\title{
FIGURA 1
}

\section{Printscreen da página inicial do PCN Brasil}

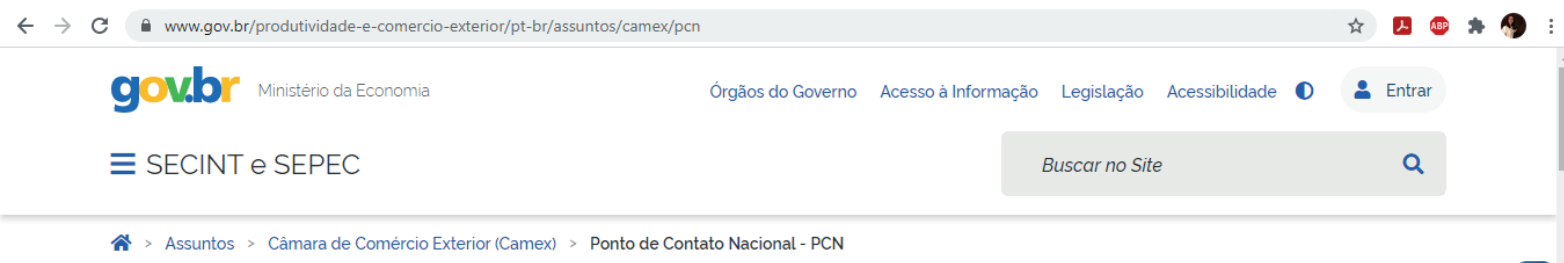

\section{Ponto de Contato Nacional Brasil - PCN}

\author{
Coronavirus (COVID-19)
}

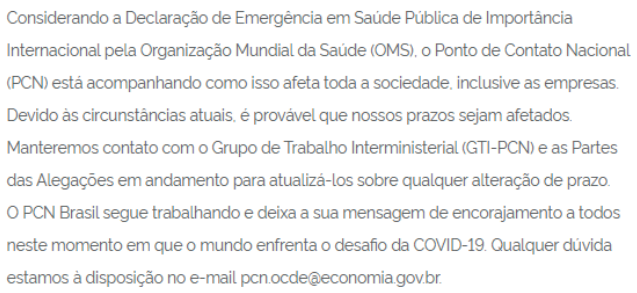

Considerando a Declaração de Emergència em Saúde Pública de Importância Internacional pela Organização Mundial da Saúde (OMS). o Ponto de Contato Nacional (PCN) está acompanhando como isso afeta toda a sociedade. inclusive as empresas Devido às circunstảncias atuais, è provável que nossos prazos sejam afetados Manteremos contato com o Grupo de Trabalho Interministerial (GTI-PCN) e as Partes das Alegaçōes em andamento para atualizá-los sobre qualquer alteração de prazo. O PCN Brasil segue trabalhando e deixa a sua mensagem de encorajamento a todos neste momento em que o mundo enfrenta o desafio da COVID-19. Qualquer dúvida estamos à disposição no e-mail pcn.ocde@economiagovibr

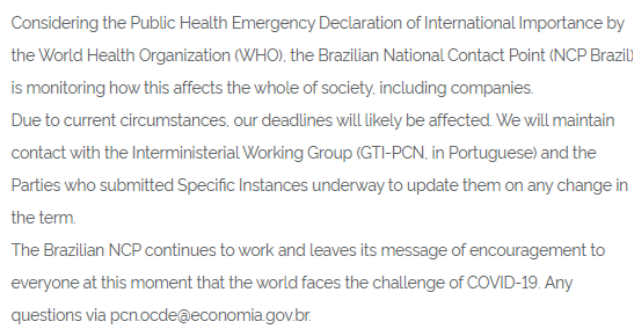

Considering the Public Health Emergency Declaration of International Importance by the World Health Organization (WHO), the Brazilian National Contact Point (NCP Brazil is monitoring how this affects the whole of society. including companies. Due to current circumstances, our deadlines will likely be affected. We will maintain contact with the Interministerial Working Group (GTI-PCN. in Portuguese) and the Parties who submitted Specific Instances underway to update them on any change in the term

The Brazilian NCP continues to work and leaves its message of encouragement to everyone at this moment that the world faces the challenge of COVID-19. Any questions via pcnocde@economiagovbr

Fonte: PCN Brasil.

O site não faz uso de recursos de hipermídia além do vídeo, e muitos links e botóes de acesso a documentos importantes não funcionam, entre os quais vale citar o relatório de encerramento e o processo de consulta pública do manual de procedimentos. Os botóes de consultar as alegaçóes de inobservância já recebidas pelo PCN, entenda o processo de devida diligência da OCDE e confira a lista de PCNs pelo mundo também não funcionam. Caso alguém clique neles, aparece o aviso indicado na figura 2.

O link da página relativo à $\mathrm{OCDE}$ remete à página elaborada pelo Ministério da Economia, com poucos recursos de hipermídia e sem conexão com a página dedicada ao Brasil no portal da $\mathrm{OCDE}^{19}$ e tampouco ao site oficial da organização. ${ }^{20}$ Temos, nesse sentido, os mesmos links em duplicidade, sem hierarquia de informaçôes e pouca utilização de recursos de hipermídia. Não há destaque para a relevância da observação das Diretrizes para acesso como membro à OCDE. A estrutura lógica da apresentação das informaçóes também poderia ser melhorada, de modo a tornar mais claras as funçóes e prerrogativas do órgáo, tais como due diligence, atividades promocionais e projetos especiais em CER.

19. Disponível em: <https://www.oecd.org/latin-america/countries/brazil/brasil.htm\#: :text> .

20. Disponível em: <https://www.oecd.org/>. 


\section{FIGURA 2}

Resultado dos links e botões que não remetem aos documentos indicados, especialmente os links dos relatórios das alegações

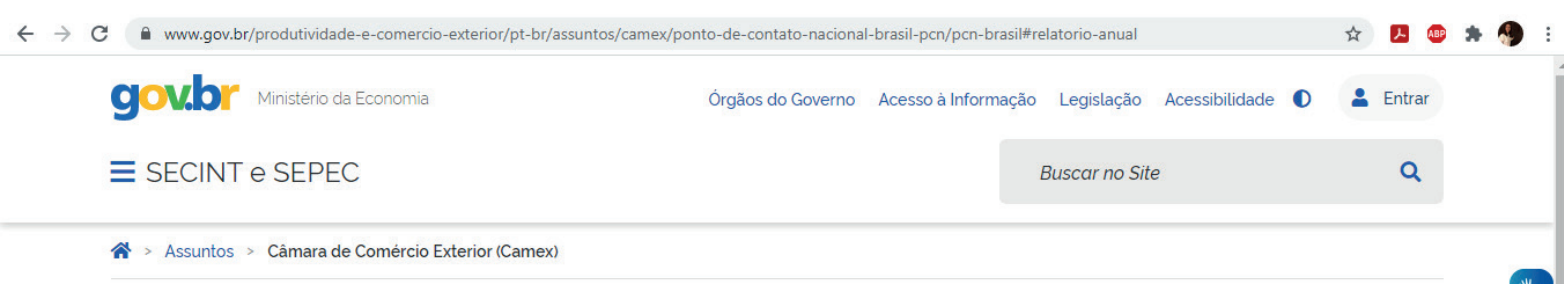

Desculpe, mas esta página não existe...

Pedimos desculpas pelo inconveniente, mas a página que vocè estava tentando acessar não existe neste endereço.

Se vocè está certo que o endereço informado está correto mas está encontrando um erro, por favor contate a Administraçāo do Site.

Obrigado.

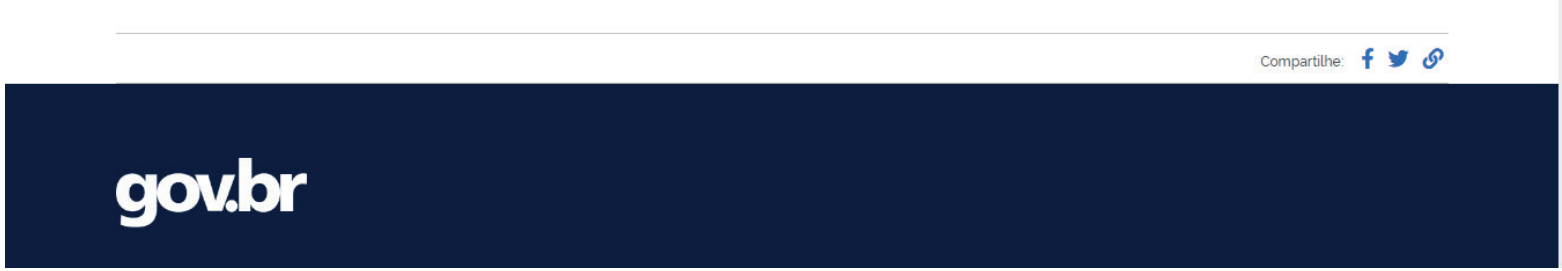

Fonte: PCN Brasil.

O site não apresenta seção de notícias ou de divulgação de eventos e de contato com a imprensa. Não há destaque para os eventos do PCN Brasil, em rede e com a OCDE. Inexistem informaçóes sobre o projeto desenvolvido em conjunto com a América Latina e Caribe em CER. Quando uma alegação é concluída, essa informação também não aparece na página. Informaçôes interessantes presentes nos relatórios do Comitê Nacional de Investimento (Coninv) não estão disponíveis de modo a atrair a imprensa e gerar notícias sobre o PCN, além de informar o público interessado. Note-se que uma seção de notícias no site contemplando estas pautas faria com que o PCN Brasil atendesse aos indicadores referentes à divulgação de açôes promocionais e de eventos organizados e coorganizados pela agência para a promoção das Diretrizes e de instrumentos de due diligence.

O quadro 2 mostra os critérios adotados para a análise qualitativa do site. Eles foram definidos com base em Correa (2008) e navegação cuidadosa da página por dois especialistas em comunicação organizacional da área de jornalismo e relaçóes públicas. 
QUADRO 2

Análise qualitativa do site do PCN Brasil

\begin{tabular}{|c|c|}
\hline Critério & Avaliação \\
\hline 1. Fonte de acesso ao site. & Acesso fácil por meio da ferramenta de busca do Google. \\
\hline 2. Estar nas primeiras páginas de busca do setor de atuação. & $\begin{array}{l}\text { É necessário digitar o nome completo do órgão ou PCN Brasil para aparecer na primeira } \\
\text { página, caso contrário aparece a sigla de Parâmetros Curriculares Nacionais, mais conhecida. }\end{array}$ \\
\hline 3. Velocidade de carregamento. & Muito boa, abaixo de dois segundos. \\
\hline 4. Layout/ apelo visual /equilíbrio entre gráficos e textos. & $\begin{array}{l}\text { Apresenta boa tipologia, mas não tem recursos visuais. Não tem elementos ilustrativos, além } \\
\text { de textuais. }\end{array}$ \\
\hline 5. Uso de recursos como vídeos e podcasts. & Um vídeo sobre o órgão (ver análise específica sobre o vídeo). Não estão incluídos podcasts. \\
\hline 6. Textos disponíveis em inglês. & $\begin{array}{l}\text { A mensagem inicial do texto informando sobre a modificação do atendimento durante a } \\
\text { pandemia, as Diretrizes e o Manual de Procedimentos para Instâncias Específicas/alegações } \\
\text { estão disponíveis, mas não os relatórios anuais e relatórios de encerramento das alegações. } \\
\text { Não existem textos em espanhol. }\end{array}$ \\
\hline $\begin{array}{l}\text { 7. Usabilidade: linguagem e posicionamento claro; botões e menus com } \\
\text { acessibilidade para smartphones. }\end{array}$ & $\begin{array}{l}\text { Linguagem textual técnica, o principal recurso para navegação é a barra de rolagem de } \\
\text { textos com links, grande parte deles indisponíveis. Alguns botões não funcionam. Pouca } \\
\text { adaptação para smarthphones, tornando difícil a leitura no aparelho. O site possui o recurso de } \\
\text { acessibilidade para deficientes auditivos em libras. }\end{array}$ \\
\hline $\begin{array}{l}\text { 8. Sistema eletrônico para inserção das alegações de inobservância } \\
\text { das Diretrizes. }\end{array}$ & $\begin{array}{l}\text { Indisponivel, as alegações estão sendo feitas pelo e-mail <pcn.ocde@economia.gov.br> ou } \\
\text { pelo correio. }\end{array}$ \\
\hline 9. Métricas de quantidades de ações específicas por visitante. & Não disponível, em especial o número de visitantes da página. \\
\hline $\begin{array}{l}\text { 10. Uso de ferramentas do Google Analytics: origem do tráfego e metas, sem } \\
\text { rush, hashtag e endereços. }\end{array}$ & Informação não disponível. \\
\hline $\begin{array}{l}\text { 11. Uso da ferramenta Google Trends que permite a comparação com } \\
\text { palavras-chave utilizadas por organizações semelhantes. }\end{array}$ & Informação não disponível. \\
\hline 12. Avaliação das opções disponíveis para navegar no site. & $\begin{array}{l}\text { Poderia ter uma melhor disposição e arquitetura de informações (explicação sobre o PCN e } \\
\text { vídeo no início). Links importantes não funcionam. }\end{array}$ \\
\hline 13. Número de cliques para chegar onde se deseja. & São poucos, mas alguns links importantes não dão acesso à informação anunciada. \\
\hline $\begin{array}{l}\text { 14. Documentos relevantes que permitam a transparência e auditagem das } \\
\text { alegações aceitas. }\end{array}$ & $\begin{array}{l}\text { O link para o processo de consulta pública do manual de procedimentos não está disponível. As } \\
\text { declarações das instâncias específicas não estão disponiveis. }\end{array}$ \\
\hline $\begin{array}{l}\text { 15. Pesquisa de satisfação on-line após a visita do usuário sobre o canal } \\
\text { de comunicação e possíveis dificuldades, dúvidas, sugestões e grau de } \\
\text { confiança na agência. }\end{array}$ & Não é realizada. \\
\hline $\begin{array}{l}\text { 16. Autonomia da equipe do PCN para atualizações e organização de } \\
\text { informações no site. }\end{array}$ & Não há autonomia. \\
\hline 17. Seção de notícias/ divulgação/ assessoria de imprensa. & Não possui. \\
\hline
\end{tabular}

Elaboração da autora.

\subsubsection{Vídeo institucional}

O vídeo foi postado em 9 de dezembro de 2019 no canal do Ministério da Economia no YouTube e é bem realizado tecnicamente. Tem narração em off e cenas de bancos de imagens com executivos multiculturais e relativas à sustentabilidade, além de figuras que exemplificam didaticamente os conceitos e conteúdos e legendas em inglês. Tem 2 minutos e 21 segundos de duraçáo e pode ser acessado por meio de um link direto da página do PCN Brasil. O vídeo aborda as multinacionais e sua cadeia de fornecedores; a relaçáo com os Objetivos do Desenvolvimento Sustentável (ODS) promovido pela Organização das Nações Unidas (ONU); a estrutura; as denúncias sobre as violações das Diretrizes; e o PCN Brasil.

O final do vídeo pode confundir o espectador, já que o áudio de encerramento informa (entre 01:57 e 02:14): "A secretaria executiva da CAMEX, órgão integrante do Ministério da Economia e que tem trabalhado na disseminação do PCN para atrair investimentos qualificados e promover a inserção das empresas brasileiras no mercado externo. Mais informaçôes no site <www.pcn.economia. gov.br>.”. O lettering e o áudio informam o endereço eletrônico errado, não sendo possível acessar 
a página com esta direção. Ademais, pode-se, logicamente, inferir que o PCN possa contribuir para a inserção brasileira no mercado internacional, contudo essa não é sua principal função, mas da CAMEX. As assinaturas são do governo brasileiro/Ministério da Economia e ODS. Não estão disponíveis informaçóes sobre a produtora do vídeo.

Existem duas postagens do mesmo vídeo no YouTube. A segunda tem como título "OCDE e o Brasil", não se refere explicitamente ao PCN Brasil e surge como nono na lista de sugestôes do canal em buscas para a palavra-chave OCDE feitas a partir do Brasil. Quando digitada a expressão "Ponto de Contato Nacional”, o vídeo aparece em primeiro na lista, mas a informação é de que teve apenas 142 visualizaçóes desde a postagem (ocorrida em 2 de dezembro de 2019). Já o vídeo acessado a partir do link na página do PCN possui pouco mais de 1.300 visualizações (até meados de fevereiro de 2021), uma média de pouco mais de 100 visualizaçóes mensais desde que foi postado.

\subsubsection{Manual de Procedimentos para Instâncias Específicas}

Esse documento é extremamente importante, uma vez que versa sobre os processos e regras relativos às denúncias de empresas que violaram as Diretrizes. A OCDE recomenda que seja um documento elaborado por consulta pública e que esteja disponível on-line. O ideal é que o texto seja claro, didático e compreensível a uma variedade de partes alegantes (denunciantes) como indivíduos, sindicatos, ONGs, empresas e governos.

O Manual de Procedimentos para Instâncias Específicas está disponível nas versões inglês e português e pode ser baixado em PDF. ${ }^{21}$ Como anexo, está o Formulário para Submeter Instância Especifica ao Ponto de Contato Nacional, também em formato PDF (ou seja, não editável por usuários pouco familiarizados ao uso de ferramentas de edição), que precisa ser enviado para o órgão por e-mail ou por correio (existe um sistema eletrônico para envio direto das alegaçóes, mas encontra-se indisponível por problemas técnicos). Essa maneira, apesar de mais trabalhosa, é comumente adotada pelos PCNs, inclusive em países-membros da OCDE como França, Holanda e Itália.

O documento apresenta linguagem técnica, clara e concisa, e mostra detalhadamente todas as etapas do processo e os prazos. Conta com glossário e links para os documentos legais de normatização do PCN Brasil e assemelha-se à estrutura dos manuais de procedimentos de outros PCNs. Como sugestáo, poderia contar com figuras, ampliar os termos do glossário e trazer casos de alegaçóes concluídas como exemplos.

\subsubsection{Relatórios anuais}

Estão disponíveis em português três relatórios anuais de atividades para o Coninv, supervisor legal do PCN Brasil, para os anos de 2019 e 2020 (primeiro e segundo semestre). No documento constam as seguintes partes: contextualização, promoção de parcerias, mecanismo não judicial de solução de controvérsias (instâncias específicas), relacionamento com OCDE e coordenação de políticas de CER. Os documentos são sucintos, mas ilustrativos do imenso volume de atividades e trabalho realizado pelo PCN Brasil. Não apresentam informaçóes detalhadas sobre estrutura de recursos humanos e materiais do PCN, nem um balanço final sobre as atividades.

21. Disponível em: <https://www.gov.br/produtividade-e-comercio-exterior/pt-br/assuntos/camex/pcn/produtos/formularios/pcn-manual-deprocedimentos-para-instancias.pdf>. 
O relatório de 2020 está disponível no site desde a segunda quinzena de fevereiro de 2021 esse é um aspecto positivo do PCN Brasil na análise comparativa. Outros PCNs, inclusive de países desenvolvidos, nem sempre conseguem manter atualizadas as postagens de seus relatórios. O PCN francês disponibilizou somente até o ano de 2018 e os PCNs do Chile, Holanda e Itália disponibilizaram os relatórios até 2019.

Também estão disponíveis os relatórios para a OCDE desde o ano de 2013 até o primeiro semestre de 2020. Os documentos não são padronizados e variam muito em relação às informaçóes apresentadas. A maioria das informaçóes está em inglês e trata-se de formulário, criado pela OCDE.

\subsubsection{Desafios do PCN Brasil em relação à comunicação}

De acordo com informaçóes prestadas pela vice-coordenadora, a comunicação institucional do PCN Brasil não é feita por uma assessoria exclusiva do órgão. Assim, depreende-se que não há planejamento integrado e estratégico das açóes de comunicação (assessoria de imprensa, publicidade/marketing e relaçóes públicas).

O modelo criado por Kunsch (2003) é bastante instrumental, uma vez que alinha a comunicação aos objetivos estratégicos a serem atingidos pelas organizaçôes. Integra diferentes áreas da comunicação e administrativas, bem como contempla a diversidade e especificidades de públicos. A forma de atuação dos PCNs pressupóe o diálogo permanente e a junção entre objetivos organizacionais e comunicacionais bem como uma sintonia fina entre equipes de gestores técnicos e comunicacionais. Nesse sentido, a equipe técnica deve sempre pautar os temas mais importantes a serem destacados, com base no mandato, orientações da OCDE e particularidades das partes interessadas. Além disso, a comunicação deve pautar o PCN como um dos principais atores na implementação da CER das multinacionais.

Durante o período de coleta de dados não foi possível identificar notícias veiculadas nos meios de comunicação (imprensa, portais de notícia, rádio, televisão) sobre as atividades do PCN Brasil. As buscas foram realizadas na internet em janeiro de 2021, o que pode indicar problemas de visibilidade, divulgação e conhecimento do órgão pela imprensa e opinião pública.

As relações comunicativas acontecem num cenário dinâmico, complexo e multissistêmico de relacionamentos: com equipe técnica com representantes interministeriais, mediadores, alegantes, alegados, representantes de entidades empresariais, sindicatos, ONGs, mídia, diferentes setores do governo, rede dos PCNs, OECD Watch, OIT, BIAC, organizaçôes do Sistema Naçóes Unidas etc. Nesse sentido, é preciso definir uma política de comunicação que permita o cumprimento do mandato da agência, estabelecer e manter relações com as partes interessadas. O desafio é maior pelo fato de a agência fazer parte da estrutura de comunicação governamental e ter pouca autonomia para mudanças.

Os processos comunicacionais do PCN subordinam-se e fazem parte da estrutura de comunicação do governo brasileiro, em especial do Ministério da Economia. Tem, portanto, uma série de limitaçóes que são impostas pelo padrão da comunicação oficial, especialmente no que diz respeito aos sites públicos, um dos principais instrumentos de comunicaçáo das açóes governamentais. Isso, possivelmente, limita a autonomia de atualizaçôes e o provimento adequado de recursos orçamentários, materiais e humanos para realização de uma comunicação estratégica e integrada. O resultado é notavelmente sentido em relação à variedade dos recursos disponíveis e à qualidade da informaçáo disseminada. Há pequena potencialização dos instrumentos de comunicação, de forma diferente do que ocorre no setor empresarial e até de outras agências públicas brasileiras nos níveis federais, estaduais e municipais. 
As fragilidades da comunicação institucional foram exacerbadas com a fusão dos ministérios da Fazenda, do Planejamento e do Desenvolvimento, Indústria, Comércio Exterior e Serviços, o que resultou em um quadro de grande complexidade para o desenvolvimento de estratégias integradas de comunicação e grandes perdas informacionais e da memória institucional do órgáo. Esse contexto é resultante dos riscos inerentes à migração e à complexidade da organização de um grande volume de informaçóes de diferentes agências, da integração entre os diferentes canais comunicacionais do governo e da falta de capacitação das equipes de comunicação e tecnologia da informação em temas da CER e relativas às Diretrizes.

Diante deste quadro, pode-se inferir, portanto, que aumentaram as lacunas e a indefinição de responsabilidades na nova estrutura de comunicação ministerial e menor autonomia da equipe do PCN na coordenação da comunicação e na divulgação das atividades de promoção das Diretrizes. Nesse cenário, é importante definir uma política de comunicação e um planejamento integrado de comunicaçáo que contemple o mandato do PCN e aumente a efetividade para exercer suas funçóes de promover as Diretrizes, lidar com as alegaçóes e tratar de questóes de due diligence, o que implica dispor de instrumentos de comunicaçáo dialógicos e de qualidade.

\section{CONSIDERAÇÕES FINAIS}

Nosso objetivo foi verificar se os requisitos relativos às comunicaçóes previstos pelas Diretrizes da OCDE são atendidos pelo PCN Brasil e realizar uma análise qualitativa dos ICIs com vistas ao aprimoramento dos processos comunicacionais. Observamos que o PCN Brasil atende a maioria dos requisitos formais da OCDE em relação aos indicadores de avaliação das comunicaçóes. Entretanto, na análise qualitativa dos ICIs, verificou-se o escasso uso de recursos de atratividade, persuasão e dialogicidade. É necessário incrementar o site, principal meio de comunicação do PCN, para que a agência tenha maior visibilidade, reconhecimento e transparência em relação aos processos das alegaçôes e promova as Diretrizes da OCDE.

Dessa maneira, sugerimos o desenvolvimento de ações estratégicas e integradas de comunicação para a promoçáo da CER das multinacionais entre as partes interessadas. Destacamos a necessidade de implementar as estratégias comunicativas com a liderança e maior autonomia da equipe técnica para atualização e hierarquização das informaçóes na arquitetura do site. Propomos que o planejamento e a execução das açóes comunicacionais sejam desenvolvidos em sinergia com as áreas de comunicação e tecnologia da informação.

Entre as limitaçóes da pesquisa, destacamos que o estudo foi realizado tendo como base as referências dos indicadores de comunicaçôes elaborados OECD Watch e a análise dos instrumentos de comunicação do PCN Brasil. Uma abordagem mais completa, em estudos futuros, implicaria ouvir as partes interessadas buscando apreender as nuances e especificidades dos discursos e práticas comunicativas estabelecidas entre os públicos internos e externos e, principalmente, com as partes interessadas. 


\section{REFERÊNCIAS}

CÔRREA, E.S. Comunicação Digital e seus usos institucionais. In: KUNSCH, M. M. K. (Org). Gestão estratégica da comunicaçáo organizacional e relaçóes públicas. São Caetano: Difusão Editora, 2008.

DUARTE, J. Instrumentos de comunicação pública. In: . Comunicaçáo pública: Estado, mercado, sociedade e interesse público. São Paulo: Atlas, 2009.

KUNSCH, M. M. K. Planejamento de relaçóes públicas em comunicaçáo integrada. Sáo Paulo: Summus, 2003.

MATOS, H. A comunicação pública na perspectiva da teoria do reconhecimento. In: KUNSCH, M. M. K. Comunicaçáo pública, sociedade e cidadania. São Caetano do Sul: Difusão, 2011.

OECD - ORGANISATION FOR ECONOMIC CO-OPERATION AND DEVELOPMENT. Annual report on the OECD Guidelines for Multinational Enterprises 2018. Paris: OECD, 2019.

. Annual report on the OECD Guidelines for Multinational Enterprises 2019. Paris: OECD, 2020a.

National contact points for responsible business conduct. Paris: OECD, $2020 \mathrm{~b}$. 



\title{
UMA AVALIAÇÃO DA PARTICIPAÇÃO DO BRASIL NAS DIRETRIZES DA OCDE PARA CONDUTA RESPONSÁVEL DE EMPRESAS MULTINACIONAIS
}

Bernardo Mueller ${ }^{1}$

Felipe Roviello²

\begin{abstract}
SINOPSE
As Diretrizes da Organização para a Cooperação e Desenvolvimento Econômico (OCDE) para conduta empresarial responsável oferecem um fórum ao qual grupos e indivíduos podem denunciar violações por parte de empresas multinacionais, assim como mediação entre as empresas denunciadas e os denunciantes na busca de acordos e solução dos conflitos. Com atuação em 49 países, é um dos maiores programas de responsabilidade social corporativa do mundo. Como o programa não tem poder legal de sanção e a participação das empresas é voluntária, ele depende da sua capacidade de dar visibilidade às denúncias e da percepção por parte das empresas dos custos envolvidos por meio de impactos à sua imagem e reputação. Neste trabalho, nós detalhamos os casos mediados pelo Ponto de Contato Nacional (NCP) do Brasil. Realizamos também testes quantitativos por estudos de eventos com dados do mercado acionário e mostramos que há evidência que uma denúncia ao programa efetivamente impõe custos às empresas.
\end{abstract}

Palavras-chave: responsabilidade social corporativa; governança corporativa; OCDE; estudo de eventos; Brasil.

\begin{abstract}
The OECD Guidelines for Responsible Business Conduct provide a forum in which groups and individuals can report violations by multinational companies, and also mediation between reported companies and whistleblowers towards reaching agreements and arbitrating conflicts. Operating in 49 countries, it is one of the largest corporate social responsibility programs in the world. As the program has no legal sanctioning power and the companies' participation is voluntary, it depends on its ability to give visibility to complaints, and also on the perception by companies of the costs and risks to their image and reputation. In this paper we detail the cases mediated by the national contact point (NCP) in Brazil. We also carry out quantitative tests through events studies using stock market data and show evidence that a complaint to the program does effectively imposes costs on the companies.
\end{abstract}

Keywords: corporate social responsibility; corporate governance; OECD; event studies; Brazil.

JEL: M14; G14; F53.

Artigo recebido em 8/2/2021 e aprovado em 5/3/2021.

DOl: http://dx.doi.org/10.38116/bepi29art4

\section{INTRODUÇÃO}

As Diretrizes da Organização para a Cooperaçáo e Desenvolvimento Econômico (OCDE) para conduta responsável de empresas multinacionais compóem um dos maiores programas mundiais de fomento à responsabilidade social corporativa (Corporate Social Responsibility - CRS). Por meio desse programa, estabelecido em 2000 e que hoje conta com a participação de 49 países, indivíduos

1. Professor titular do Departamento de Economia da Universidade de Brasília (UnB).E-mail: <bmueller@unb.br>.

2. Mestrando em economia na UnB. E-mail: <feliperoviello@gmail.com>. 
ou grupos organizados como organizaçóes não governamentais (ONGs) e grupos de advocacia têm um fórum para denunciar açôes ou comportamentos por parte de empresas multinacionais que violem a conduta responsável empresarial, especialmente em áreas ligadas a meio ambiente, direitos humanos, questóes trabalhistas, corrupção e governança em geral. ${ }^{3}$ Com o programa, cada país mantém um Ponto de Contato Nacional (PCN) a quem a denúncia pode ser feita e que media e arbitra uma resoluçáo entre denunciantes e as empresas (OECD, 2016).

Embora trate de temas típicos de CSR, as Diretrizes diferem de açôes usuais nessa área porque a iniciativa parte de uma denúncia formal no bojo de um programa unificado a nível global. Nesse programa, quem inicia um caso é o denunciante e a empresa age reativamente ao decidir se aceita ou não participar do processo de mediação oferecido pelo programa. Os PCNs não possuem poder de sanção e requerem cooperaçáo voluntária da empresa para poder negociar uma resoluçáo. O programa conta, porém, com a visibilidade que ele é capaz de dar a uma denúncia e a percepção por parte das empresas do impacto que isso pode ter sobre a sua imagem e reputação diante da sociedade e dos mercados. Nesse sentido, o programa tem a mesma característica de soft law das quais açóes usuais de CSR também dependem.

A literatura sobre Responsabilidade Social Corporativa tem dois grandes temas dominantes. O primeiro é uma discussão normativa se empresas deveriam ou não adotar ações de CSR. Essa discussão geralmente parte da afirmação de Friedman (2007) que a única responsabilidade social das empresas é aumentar o seu próprio lucro e envolve argumentos sobre ética corporativa e falhas de mercado. O segundo tema dominante envolve determinar quais os impactos efetivos de açóes de responsabilidade social sobre a performance da empresa e também seus impactos no meio ambiente, direitos humanos e outros objetivos do programa. Identificar esses impactos e quantificá-los corretamente é uma tarefa difícil e há muitas críticas no sentido de que boa parte dos esforços das empresas são somente uma questấo de aparências com poucos benefícios concretos para a sociedade.

Neste trabalho, o nosso interesse está no segundo tema dominante. Embora haja bastante escrito sobre o histórico e o funcionamento das Diretrizes da OCDE (Thorstensen, Cortellini e Gullo, 2018; Ruggie e Nelson, 2015; Nieuwenkamp, 2013; Davarnejad, 2011), há ainda uma escassez de tentativas rigorosas de quantificação desse impacto - uma exceção é Weissman et al. (2016). A efetividade do programa depende da publicidade que consegue dar às denúncias e da reação por parte da sociedade e dos mercados a essa informaçáo. Portanto, é crucial para o funcionamento do programa que as empresas tenham a percepção que uma denúncia efetivamente pode gerar custos reputacionais significativos, senão elas poderão simplesmente ignorar as acusaçôes e se recusar a participar sem consequências. Análises descritivas, como em Ruggie e Nelson (2015), mostram que vários casos atingiram grande repercussão e publicidade, no entanto, uma leitura mais sistemática também mostra que um grande número não conseguiu engajar as empresas no processo de mediação. Há, portanto, a necessidade de análises quantitativas mais rigorosas para identificar a existência, natureza e magnitude do impacto de uma denúncia de uma empresa multinacional nas Diretrizes. ${ }^{4}$

Em Mueller e Roviello (s.d.) são usados os preços das ações no mercado acionário para realizar testes de estudos de eventos sobre o universo dos dados de denúncias na base das Diretrizes: em muitos casos, é possível identificar e quantificar um impacto negativo para as empresas denunciadas nesse

3. Para os propósitos das Diretrizes, empresas multinacionais são empresas com operações em mais de um país. Esses princípios se aplicam, portanto, a empresas nacionais de grande porte, como Banco do Brasil, Vale, Natura, Petrobras etc.

4. A base de dados com informações detalhadas sobre cada denúncia está disponível em: <http://mneguidelines.oecd.org/database/>. 
programa. Neste trabalho, fazemos o mesmo, mas focando exclusivamente nas empresas brasileiras que foram denunciadas. Nas bases de dados da OCDE, o PCN do Brasil é o quarto mais ativo, com 31 casos, e o Brasil é o quarto maior hospedeiro de empresas denunciadas, com 33 casos. A questão a ser investigada aqui é se essas empresas sofreram algum impacto por ter recebido as denúncias de terem violado as Diretrizes da OCDE.

Essa questão se reveste de importância adicional devido às pretensôes brasileiras de aceder a membro efetivo da OCDE, pelo menos desde a administração de Fernando Henrique Cardoso (1994-2002) (OECD, 2018). É também uma pretensão da própria OCDE, que vem perseguindo uma estratégia de ampliação de sua influência global através da acessão de novos membros. Em 2006, a organização estabeleceu quatro critérios para avaliar a candidatura de novos países à acessão: deveriam ter like-mindedness (afinidade de ideias e valores); serem atores significativos; a acessão deverá trazer benefícios mútuos; e levar em conta consideraçôes globais geopolíticas. Acima de tudo, o país candidato deverá demonstrar uma participação ativa nos fóruns e programas da OCDE, conforme detalhado no anexo do relatório do encontro ministerial da OCDE realizado em 2017 (OECD, 2017).

O Brasil já é o país não membro com maior participação em comissões, instrumentos legais e outras atividades da OCDE, e em 2017 o governo formalizou a candidatura oficial do país para se tornar membro efetivo (Mello, 2020). Desde 2007 a OCDE tem seguido uma estratégia de engajamento prioritário (enhanced engagement) em que cinco países parceiros são tidos como parceiros-chave (key partners) para acessão - incluindo Brasil, China, Índia, Indonésia e África do Sul. Porém, apesar de o Brasil ser, segundo OECD (2018), o país mais engajado em cooperação com a OCDE de todos key partners e de todos países que já se candidataram à acessão, o processo não tem avançado significativamente devido a uma divisão entre os membros sobre a velocidade e a forma pela qual deve se dar o processo de alargamento, com os Estados Unidos defendendo uma expansão mais gradual e controlada (Cozendey, 2019). Embora a participação ativa do PCN brasileiro dentro das Diretrizes já contribua a favor da pretensão brasileira de acessão, essa candidatura pode ficar ainda mais fortalecida se houver evidências de que essa participação tem sido efetiva em influenciar o comportamento das empresas multinacionais. Este trabalho usa dados das denúncias junto ao PCN brasileiro e dados do mercado acionário para determinar se existem tais evidências.

O trabalho está estruturado em três seções adicionais. A próxima seção faz uma breve descrição do funcionamento das Diretrizes da OCDE para empresas multinacionais. A seção subsequente descreve a participação brasileira no programa através de dados das denúncias feitas junto ao PCN brasileiro. Finalmente, a última seção realiza testes para determinar se há evidência que essas denúncias afetaram as empresas negativamente. Um efeito negativo sobre as empresas é uma condição necessária para que o programa não seja inócuo e tenha o potencial de induzir um comportamento mais socialmente responsável.

A próxima seção traz a descrição das Diretrizes da OCDE. A seção 3 descreve a natureza e os detalhes dos casos que envolvem empresas e o PCN brasileiros, e a seçáo 4 descreve os métodos usados nos testes. Os testes e os resultados serão descritos na seção 5 e a seção 6 traz as consideraçóes finais.

\section{AS DIRETRIZES DA OCDE PARA CONDUTA CORPORATIVA RESPONSÁVEL}

Uma das principais funçóes da OCDE é estabelecer padróes de governança para facilitar o comércio e a integração global, e as Diretrizes para conduta responsável de empresas multinacionais são um 
dos seus principais programas. Estabelecido em 2000, o programa já passou por diversas revisóes, sendo a última e mais importante em 2011. Neste trabalho, os dados descritivos que usamos incluem todos os casos no histórico do programa, porém, os testes focam nos casos desde 2011, para os quais os dados são melhores e mais uniformes.

Até o final de 2020, 487 casos haviam sido abertos junto ao programa. ${ }^{5}$ As principais áreas de classificação das denúncias são emprego e relaçóes industriais $(23,95 \%)$, políticas gerais $(23,48 \%)$ e direitos humanos $(16,28 \%)$. Nos anos mais recentes houve um aumento no número de casos na área ambiental e de direitos humanos. Em termo de setores, as maiores concentraçôes de denúncias se deram em manufaturas $(24,21 \%)$, mineração e pedreiras $(13,61 \%)$ e outras atividades $(12,97 \%)$.

Empresas multinacionais têm sede em um determinado país, mas operam em vários outros. Assim, as denúncias podem envolver tanto o PCN do país-sede como um ou mais dos países hospedeiros onde a empresa atua. As Diretrizes encorajam a cooperação entre PCNs. Os cinco PCNs mais ativos são o Reino Unido (55 casos), Estados Unidos (48), Países Baixos (39), Brasil (31) e França (31). Já os principais países hospedeiros das empresas denunciadas são os Estados Unidos (36), República Democrática do Congo (35), Brasil (33), Índia (25) e Reino Unido (19). No programa como um todo, os principais denunciantes são as ONGs e os sindicatos, seguidos por indivíduos, sendo que só podem denunciar os que forem efetiva e diretamente afetados pela ação da empresa, ou seu representante formal. Quanto à duração dos casos, mais de metade é resolvida em menos de dois anos, embora vários se arrastem por mais de três ou quatro.

Uma questão importante do programa é conseguir o engajamento da empresa denunciada no processo de mediação com os denunciantes, pois ela não pode ser legalmente forçada a reconhecer a denúncia e a participar dele: a princípio, ela pode simplesmente se recusar a reconhecer ou tomar conhecimento da questáo. A força do programa está na visibilidade que a OCDE pode dar ao caso. Com maior transparência e engajamento possibilitados por mídias sociais, empresas estão cientes da importância que questóes ligadas à responsabilidade corporativa social podem tomar. De todas as denúncias feitas às Diretrizes, $55 \%$ não obtiveram engajamento das empresas. Dos casos que chegaram à medição, desde o início do programa, 32\% resultaram em um acordo total ou parcial, embora alguns dos casos que náo levaram à acordo podem ter sido resolvidos em outras instâncias, como tribunais nacionais. Entretanto, em anos mais recentes, as taxas de engajamento e de acordos têm aumentado. Um dos desafios é justamente conseguir melhorar sua capacidade de fomentar diálogo e acordos entre denunciados e denunciantes.

Para efeito de ilustração dos casos que participam do programa, considere a denúncia contra a companhia de mineração britânica Vedanta, que foi acusada de violar solo sagrado na Índia (Nieuwenkamp, 2013), feita por um grupo de ONGs ao PCN britânico. A recusa da empresa em reconhecer a denúncia e a participar no processo de mediaçáo levou um grupo de investidores institucionais à venda das açóes da empresa dos seus portfólios. Em outro exemplo, a Royal Shell Company foi denunciada em 2011 por três ONGs de haver causado vários derramamentos de petróleo no Niger Delta. A empresa aceitou participar do processo de mediação e colocou como condição para atingir um acordo que as denúncias não fizessem parte de campanhas ou aparecessem no domínio público. As ONGs não aceitaram essas exigências porque, segundo elas, tais campanhas 
são suas principais armas de atuação. ${ }^{6}$ De acordo com Nieuwenkamp (2013, p. 174, tradução nossa), "muitos investidores, como o Fundo Norueguês de Petróleo ou o Fundo de Investimento Calvert dos Estados Unidos, usam as Diretrizes da OCDE para seus investimentos e seriamente consideram as afirmaçóes dos PCNs". ${ }^{7}$

Esses exemplos são casos mais proeminentes escolhidos justamente porque tiveram impactos facilmente reconhecidos. De maneira mais geral, no entanto, é difícil assegurar até que ponto as denúncias são ou não efetivas. Pode haver casos em que a empresa se recusa a participar, mas sofre sançóes do mercado e passa mudar o seu comportamento. Também pode haver casos em que a empresa participa e chega a um acordo, mas náo é atingida de maneira suficientemente forte para mudar suas açôes futuras. É essa dificuldade de medir impacto que torna difícil avaliar o programa a partir de uma simples leitura e tabelamento dos casos. Por isso, em Mueller e Roviello (s.d.) foram usados estudos de eventos, métodos de pareamento (propensity score matching) e um método desenvolvido pelos autores para tentar identificar estatisticamente de maneira mais rigorosa o impacto das denúncias focando onde as firmas mais sentem: no seu lucro. Neste trabalho, aplicamos alguns desses métodos aos casos que envolvem o PCN brasileiro.

\section{A EXPERIÊNCIA BRASILEIRA COM AS DIRETRIZES DA OCDE}

\subsection{Instâncias}

Os dados apresentados no gráfico 1 foram obtidos com o cruzamento da base de dados disponível no site da $\mathrm{OCDE}^{8}$ e do banco de dados de alegaçóes de inobservância do PCN brasileiro. ${ }^{9}$ É importante ressaltar que esse cruzamento foi necessário porque alguns casos que constavam na base do PCN brasileiro não constavam na base da OCDE e vice-versa.

Um caso é definido como uma denúncia contra uma empresa. Se uma denúncia contra várias empresas é apresentada de maneira conjunta, o número de casos é contado como o número de empresas denunciadas. ${ }^{10}$ No total, o PCN brasileiro analisou 43 casos, dos quais 22 já foram concluídos, 11 ainda estáo em curso e 10 não foram aceitos. Vários motivos podem levar o $\mathrm{PCN}$ a não abrir uma instância. No caso da Central Única dos Trabalhadores (CUT) contra a multinacional americana Pertechs, o alegante defendia que a empresa havia demitido injustamente um representante sindical. $\mathrm{O}$ PCN chegou a aceitar o pedido, mas recuou após a decisão de um juiz, que declarou que a companhia havia agido de acordo com a lei. Em outra ocasiáo, a ONG Americans for Democracy and Human Rights in Bahrain alegou que a empresa Condor Non-Lethal Technologies violava as diretrizes ao vender gás lacrimogêneo para o Barém. A falta de provas de que os produtos da empresa tenham causado abuso a direitos humanos e a fonte das alegaçóes - notícias de um blog de um jornalista levaram o PCN a rejeitar a denúncia.

6. 0 caso da Royal Shell está disponível em: <http://mneguidelines.oecd.org/database/instances/nl0018.htm>.

7. "Many investors, like the Norwegian Oil Fund or the US Investment Fund Calvert, use the OECD Guidelines for their investments and take PCN statements very seriously."

8. Disponivel em: <http://mneguidelines.oecd.org/database>.

9. Disponível em: <https://www.gov.br/produtividade-e-comercio-exterior/pt-br/assuntos/camex/NCP/produtos/alegacoes-de-inobservancia> . 10. Em geral, se a denúncia é apresentada de forma conjunta, a OCDE a conta como uma só instância. É por isso que aqui temos mais do que 31 casos. 
GRÁFICO 1

Status de todos os casos analisados pelo PCN brasileiro

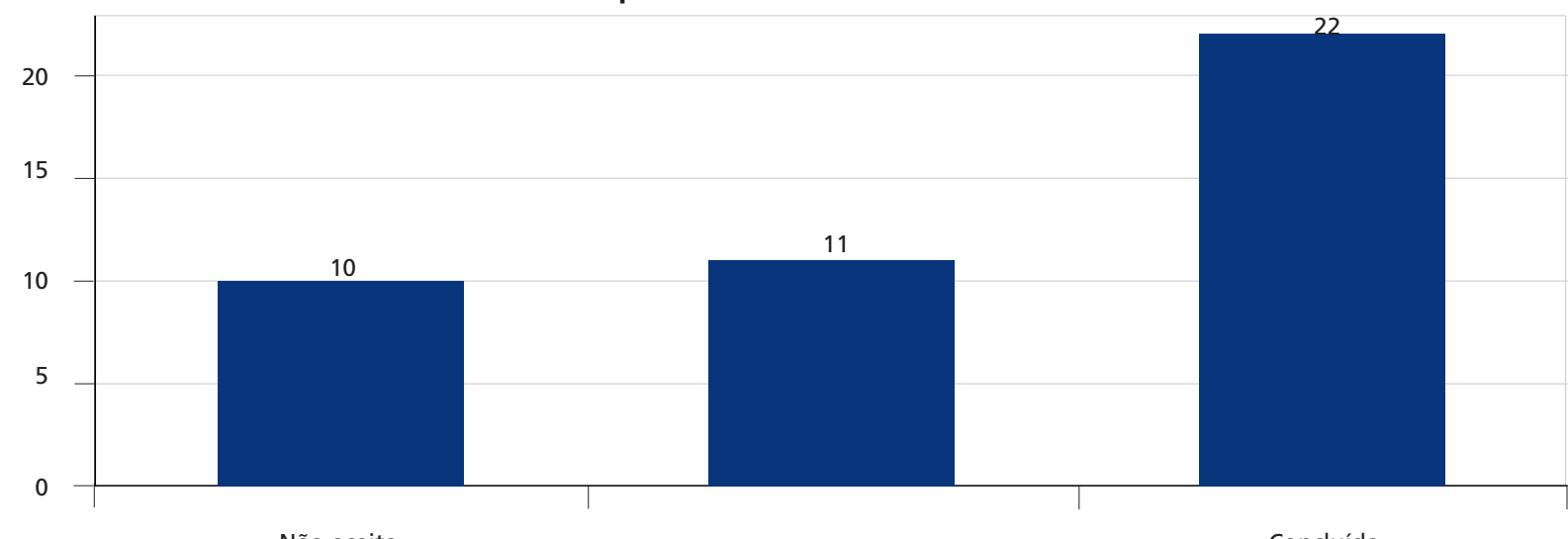

Não aceita

Em curso

Concluída

Fonte: OECD, disponível em: <http://mneguidelines.oecd.org/database/>.

Elaboração dos autores.

Uma vez que o programa busca mediar conflitos relacionados à quebra das diretrizes da OCDE, é possível dividir as instâncias por temas. No total, foi possível identificar nove temas tratados pelo PCN brasileiro, como mostra o gráfico 2. Políticas gerais (29,29\%) foi o mais recorrente, seguido de direitos humanos $(20,20 \%)$, emprego e relaçóes de trabalho $(13,13 \%)$ e meio ambiente $(9.09 \%)$. O gráfico 3 divide os casos por setor, e os três mais recorrentes são atividades financeiras e de seguros' $(17,31 \%)$, mineração $(13,46 \%)$ e agricultura $(13,46 \%)$.

GRÁFICO 2

Instâncias por temas: todos os casos

(Em \%)

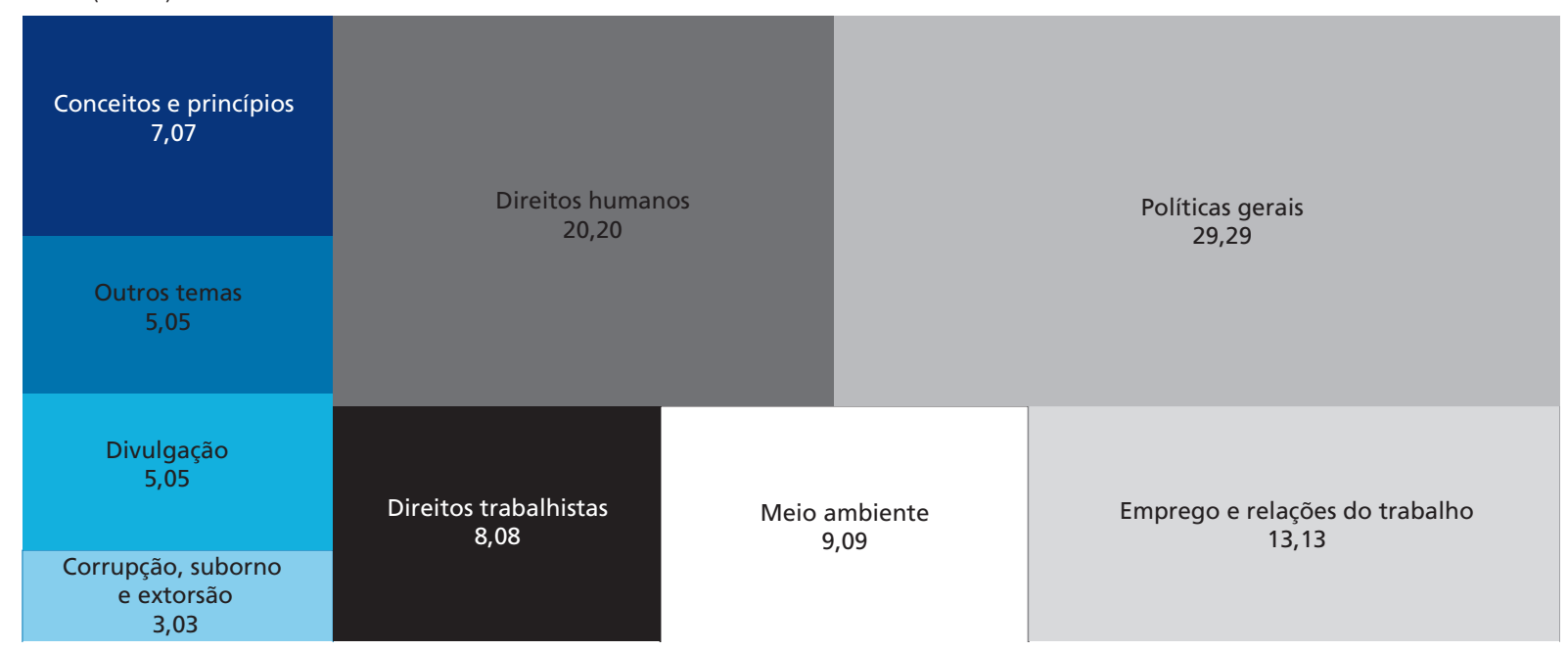

Fonte: OECD, disponível em: <http://mneguidelines.oecd.org/database/>.

Elaboração dos autores. 


\section{GRÁFICO 3}

\section{Instâncias por setor: todos os casos}

(Em \%)

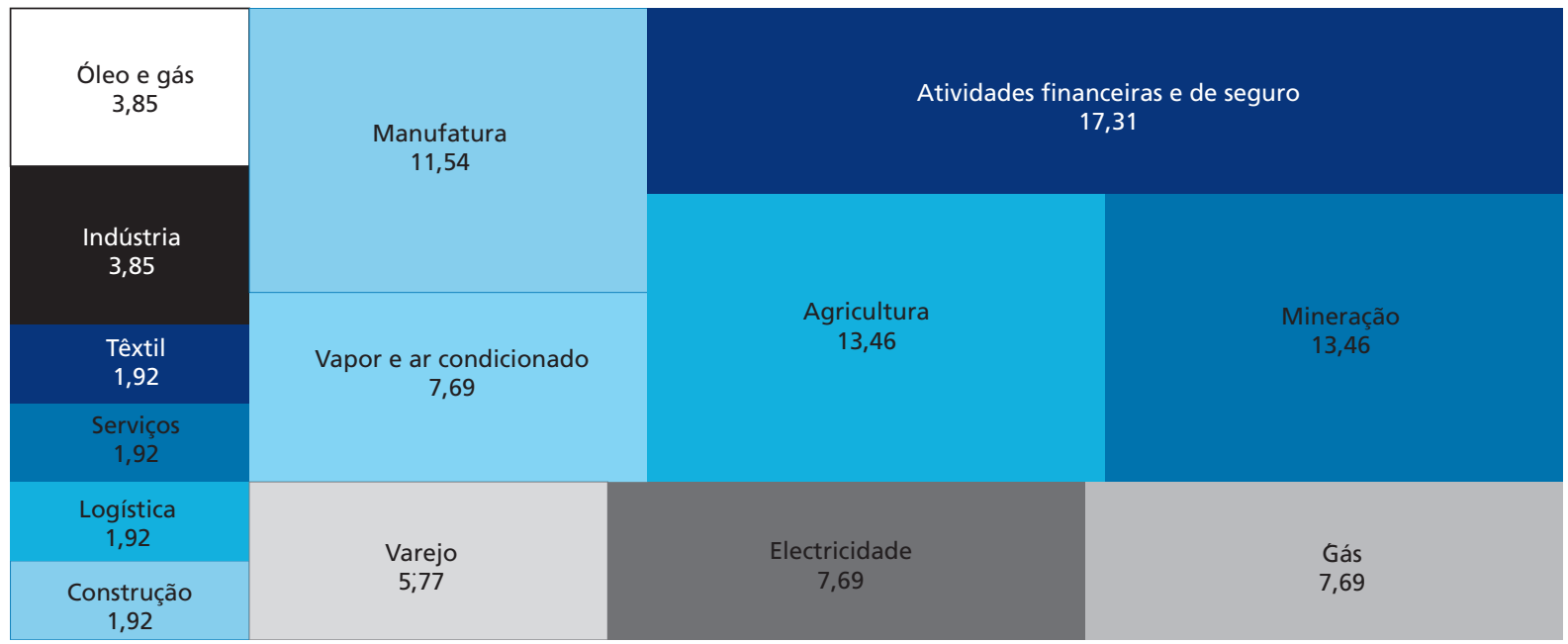

Fonte: OECD, disponível em: <http://mneguidelines.oecd.org/database/>

Elaboração dos autores.

Os denunciantes incluem desde indivíduos até sindicatos. O gráfico 4 contém diferentes categorias de denunciantes, bem como a proporção de cada um em relação ao número de casos totais. No caso brasileiro, a maior parte das alegaçóes foi feita por sindicatos $(53,1 \%)$, seguidos por indivíduos (18,4\%) e ONGs (16,3\%). Aqui, grupo significa um grupo organizado indivíduos que náo um sindicato ou uma $\mathrm{ONG}$, como por exemplo uma associação de moradores.

\section{GRÁFICO 4}

\section{Instâncias por alegante: todos os casos}

(Em \%)

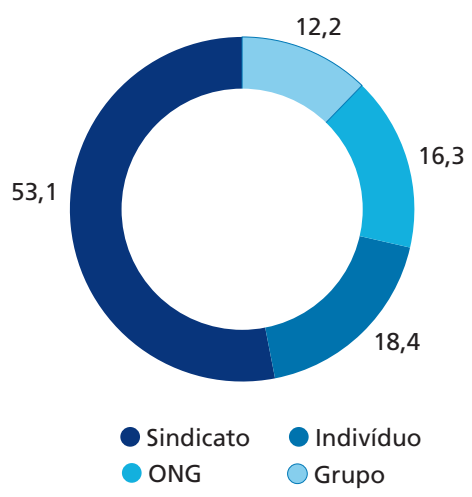

Fonte: OECD, disponivel em: <http://mneguidelines.oecd.org/database/>.

Elaboração dos autores.

É possível que uma mesma instância tenha mais do que um alegante. Por exemplo, é possível que um sindicato e um grupo de ex-trabalhadores façam conjuntamente uma denúncia contra uma firma. O mesmo vale para tema e setor, de modo que um mesmo caso pode ter mais de um tema e se encaixar em mais de um setor. 
Finalmente, o gráfico 5 mostra as empresas denunciadas e quantas vezes o PCN recebeu uma denúncia para uma dada empresa. Nem sempre é possível saber qual empresa foi denunciada devido a acordos de confidencialidade, mas foi possível obter o nome de trinta empresas diferentes. A firma com mais denúncias é a Vale S.A. (quatro denúncias), seguida da Nestlé, Itaú Unibanco, C\&A Modas Ltda, General Motorsm Eni S.p.A. e Banco Santander (duas denúncias cada). Todas as outras empresas foram denunciadas uma só vez.

GRÁFICO 5

\section{Empresas denunciadas}

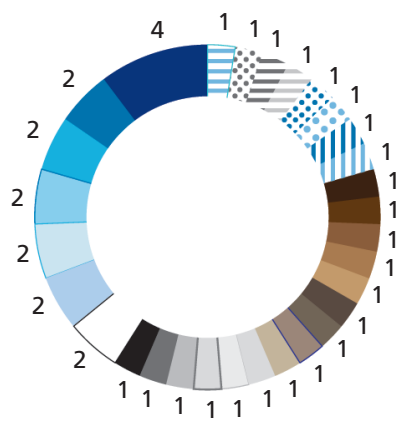

Vale S.A

Nestlé Brasil LTd

Banco Santander S.A

Eni S.p.A.

C\&A Modas Ltda

General Motors do Brasil

OItaú Unibanco S.A.

- Fidelity National BPO Brasil

Atento S.A.

BASF S.A.

Uibanco
Dunkin' Donuts
Jacobs Douwe Egberts
Pertech
Bracell Group
Usina Canabrava
McDonald's
Petrobras
ABN AMRO
BHP-Billiton

Van Oord

- Kinross Brasil Mineração

|| Esso Brasileira de Petróleo

II Banco do Brasil

$\because$ Condor Non-Lethal Technolies

$\therefore$ Illy

= Starbucks

= Unilever

$\therefore$ Shell Brasil

$\ominus$ Mappel

Fonte: $\mathrm{OECD}$, disponivel em: <http://mneguidelines.oecd.org/database/>.

Elaboração dos autores.

\subsection{Duração das instâncias}

O gráfico 6 contém a distribuição da duração para as instâncias que foram concluídas e o 7 mostra a proporção de instâncias para cada classe de duraçáo. Em média, passam-se três anos e três meses da data da denúncia até o encerramento da instância. O caso mais rápido foi o do Sindicato dos Bancários de São Paulo, Osasco e Região contra o Itaú-Unibanco, recebido pelo PCN em dezembro de 2012 e encerrado em abril do ano seguinte. O caso mais longo que foi possível identificar é o da CUT contra a C\&A Modas. A denúncia foi recebida pelo PCN em março de 2007 e se arrastou por mais de setenta meses, até ser encerrada em maio de 2013.

Mais de $40 \%$ das instâncias duram entre um e dois anos, 27,3\% delas duram mais do que cinco anos e apenas 4,5\% duram menos de um ano. A tabela 1 contém estatísticas descritivas sobre o tempo de duração das instâncias que foram concluídas. 


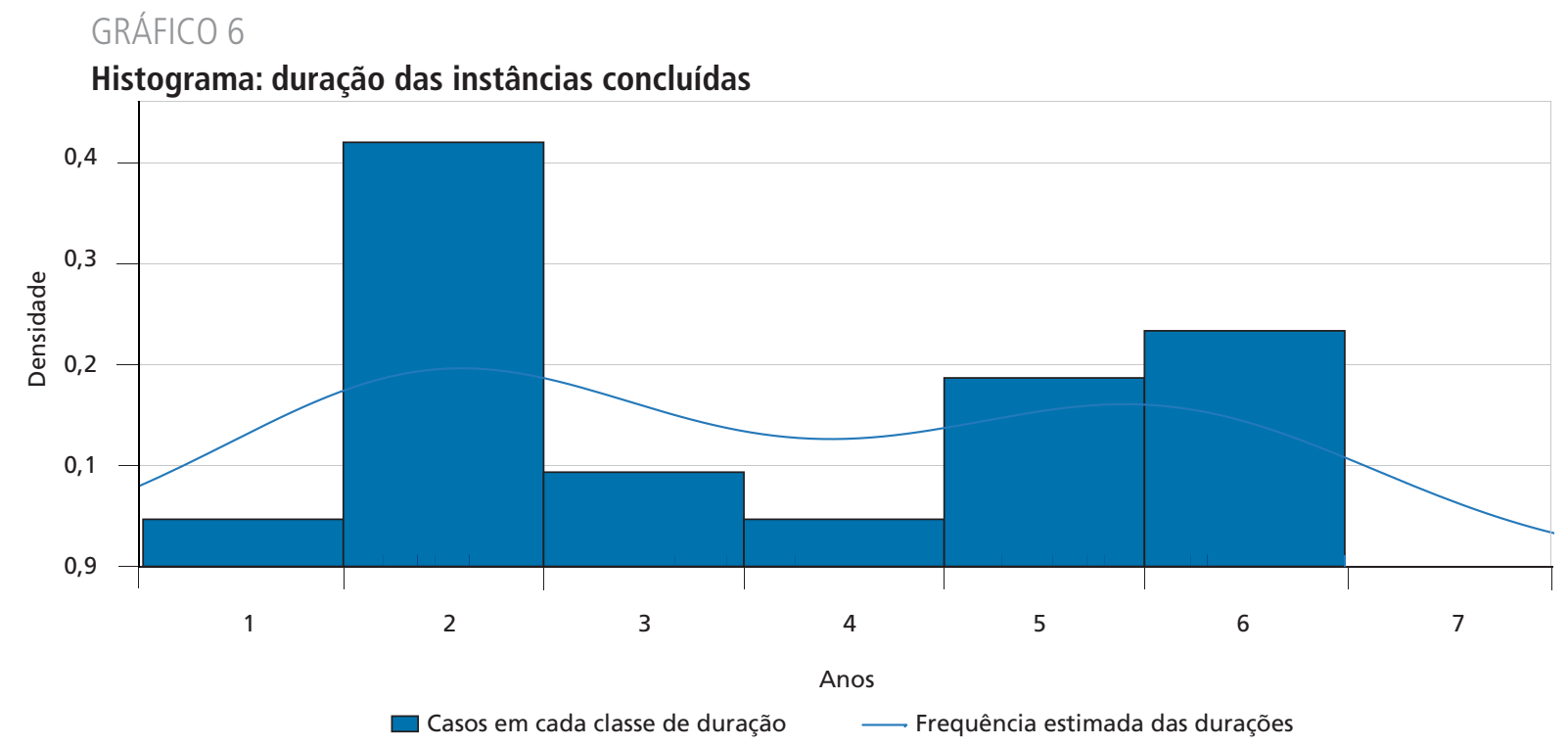

Fonte: OECD, disponivel em: <http://mneguidelines.oecd.org/database/>. Elaboração dos autores.

\section{GRÁFICO 7}

\section{Duração das instâncias}

(Em \%)
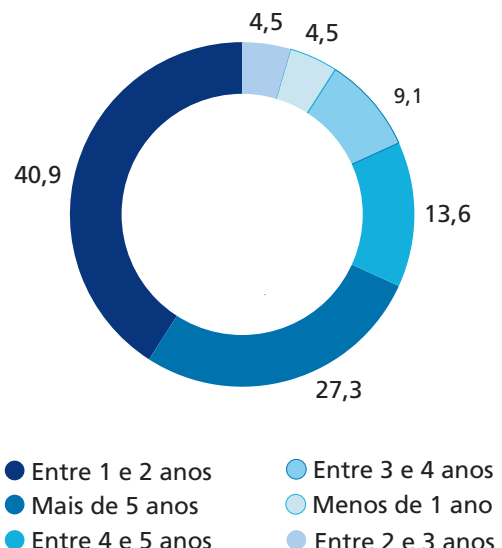

Fonte: OECD, disponível em: <http://mneguidelines.oecd.org/database/>.

Elaboração dos autores.

TABELA 1

Estatísticas descritivas: duração dos casos concluídos

\begin{tabular}{lc}
\hline & Duração \\
\hline Número & 22,00 \\
Média & 3,31 \\
Desvio-padrão & 1,79 \\
Mínimo & 0,33 \\
$25 \%$ & 1,69 \\
$50 \%$ & 3,04 \\
$75 \%$ & 4,98 \\
Máximo & 6,17 \\
\hline
\end{tabular}

Elaboração dos autores. 


\subsection{Acordos e mediações}

Após receber uma denúncia, o PCN confere os documentos e, uma vez que a aceita, oferece seus préstimos como mediador para tentar um acordo. As partes têm a opçáo de aceitar ou não. $\mathrm{O}$ gráfico 8 plota a proporção de casos que terminaram em acordo ou que tiveram mediação nas instâncias da OCDE para sua conclusão. Mais de $90 \%$ dos casos terminaram sem acordo e mais de $77 \%$ sequer resultaram em mediação entre as partes. A baixa taxa de acordos, contudo, não reflete necessariamente a taxa de sucesso do PCN brasileiro.

\section{GRÁFICO 8}

\section{Acordos e mediações: instâncias concluídas} (Em \%)

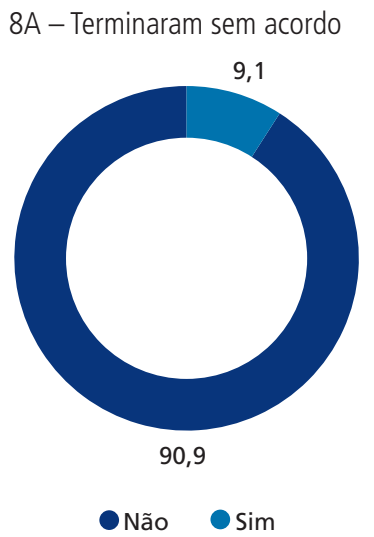

8B - Não tiveram mediação

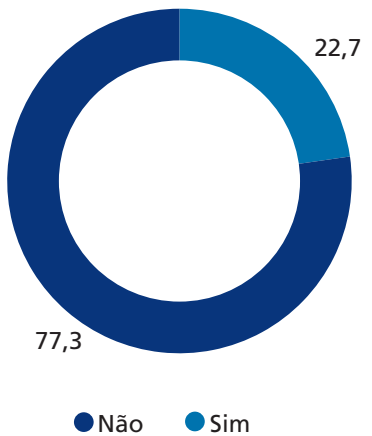

Fonte: OECD, disponivel em: <http://mneguidelines.oecd.org/database/>. Elaboração dos autores.

Um acordo ou mediação é considerado como tal apenas quando ele se dá no âmbito do programa da OCDE - assim, há diversos motivos pelos quais ele pode não ocorrer. Por exemplo, o próprio PCN pode abrir uma instância e depois fechá-la. Isso geralmente ocorre porque o resultado das investigaçóes aponta que as Diretrizes não foram violadas ou porque as partes firmaram um acordo em outra instância que não a OCDE. Esse é o caso da Confederação Nacional dos Trabalhadores do Ramo Financeiro da CUT (CONTRAF/CUT) contra o Unibanco em março de 2007. Apesar das alegaçôes de demissão sem justa causa de um representante sindical, a OCDE encerrou a instância a pedido dos alegantes, que conseguiram chegar a um acordo por meio de negociaçóes diretas. Também é o caso da ONG Coletivo Alternativa Verde e do Sindicato dos Trabalhadores no Comércio de Minérios e Derivados de Petróleo no Estado de São Paulo, que em 2008 alegavam que a Shell e a Esso Brasileira de Petróleo haviam quebrado as diretrizes de políticas gerais e de meio ambiente. A instância acabou encerrada sob o argumento da Shell de que todos os elementos da denúncia já estavam sob análise judicial. ${ }^{11}$

Há casos nos quais o próprio alegante pode solicitar o encerramento de uma instância. Em fevereiro de 2012, a CUT e o Sindicato dos Bancários e Financiários de São Paulo, Osasco e Região denunciaram a empresa Atento S.A. por quebra das Diretrizes da OCDE. A empresa havia respondido

11. A mediação pode ocorrer mesmo quando o processo já está judicializado. Um acordo conseguido via mediação pode inclusive resultar no encerramento do caso na justiça, se, por exemplo, uma parte retirar a queixa. 
às solicitações do NCP, mas os alegantes decidiram encerrar a instância dado que haviam chegado a um acordo com a companhia.

Há, porém, casos de destaque onde o PCN teve sucesso em mediar acordos entre os alegantes e as empresas denunciadas. $\mathrm{O}$ primeiro deles envolve a denúncia de um parlamentar alemão contra a empresa C\&A Brasil. Segundo o alegante, o grupo Cofra e sua subsidiária C\&A Brasil eram co-responsáveis pelo incêndio que destruiu a fábrica Tazreen Fashion em Bangladesh. O incêndio, que deixou 112 mortos e mais de 300 feridos, foi notícia em diversos veículos internacionais e levantou discussóes sobre a violação de normas de segurança do trabalho em países em desenvolvimento. ${ }^{12}$ Mesmo já tendo tomado medidas para mitigar os impactos do incêndio, ${ }^{13}$ em outubro de 2013, quando a alegação foi aceita, a empresa acatou as propostas da OCDE e criou o Programa de Segurança contra Incêndio que, segundo o NCP, tem sido aplicado por fornecedores ao redor do mundo.

Outra alegação que resultou em um acordo foi a de uma associação de moradores de Paracatu, Minas Gerais, contra a mineradora canadense Kinross. Segundo os alegantes, a utilizaçáo de explosivos pela empresa teria danificado as casas do entorno. Além disso, a infraestrutura construída teria dificultado o acesso da área rural da cidade de Machadinho à cidade de Paracatu. Após três reuniooes, a mineradora concordou em reparar as casas danificadas, a despeito de nenhuma relação entre os explosivos e os danos às casas ter sido encontrado.

Em outro caso, em março de 2018, diversos grupos e sindicatos procuraram o PCN brasileiro alegando que a Samarco, uma joint venture entre a Vale S.A. e a BHP Billiton, falhou em compensar as famílias das vítimas do rompimento da barragem do fundão em Mariana, Minas Gerais, ${ }^{14}$ além de não observar as Diretrizes para direitos dos trabalhadores e segurança no trabalho. A tragédia havia deixado dezenove mortes e causado grande dano ambiental. Embora as empresas inicialmente recusassem a mediação, eventualmente houve negociação bem-sucedida.

Esses exemplos mostram que não é possível simplesmente contar o número de acordos para inferir se o programa está tendo sucesso em incentivar um melhor comportamento das empresas em termos de responsabilidade social. Por isso, optamos por usar métodos que consigam detectar se a denúncia afeta o valor das açôes das empresas no mercado acionário. O preço das açóes e seus retornos diários refletem o lucro das empresas, e as empresas por definição são sensíveis a eventos que afetem o seu lucro.

\section{ESTUDOS DE EVENTO: TEORIA E MÉTODOS}

Para averiguar se houve efeito da denúncia da OCDE sobre a empresa denunciada, rodamos estudos de evento com as empresas da amostra cujo preço das açóes estava disponível no site Yahoo Finance para o período de análise. Neste estudo, demos preferência a açóes negociadas na bolsa de valores brasileira, inclusive em forma de Brazilian Depositary Receipts (BDRs). Quando açóes da empresa denunciada não eram negociadas no Brasil, optou-se por usar açóes em bolsas de valores do país de origem de tal companhia. Para cada ação, é possível calcular seu retorno, que é a variação percentual

12. Disponível em: <https://www.nytimes.com/2012/12/18/world/asia/bangladesh-factory-fire-caused-by-gross-negligence.html>; $<$ https://www.bbc.com/news/world-asia-20755952>; <https://edition.cnn.com/2012/11/25/world/asia/bangladesh-factory-fire/index.html>.

13. Disponível em: <https://sustainability.c-and-a.com/pt/pt/sustainability-report/2018/fornecimento-sustentavel/trabalho-justo-e-seguro/> . 14. Disponível em: <https://www.ibama.gov.br/recuperacao-ambiental/rompimento-da-barragem-de-fundao-desastre-da-samarco/documentosrelacionados-ao-desastre-da-samarco-em-mariana-mg>. 
em seu valor em um período de tempo. Retornos positivos significam que o preço da ação aumentou e negativos, que o preço diminuiu. Em geral, açôes acompanham o movimento de suas respectivas bolsas de valores e não sobem ou caem muito além dos índices de mercado. Contudo, choques específicos em uma empresa podem fazer com que suas açôes subam (ou caiam) mais do que o mercado pode prever.

Estudos de evento buscam averiguar se é possível atribuir retornos fora do esperado a eventos onde empresas sofreram choques externos. ${ }^{15}$ Para isso, é preciso "limpar" os retornos de cada ação e depois testar se esse "retorno limpo", que também é chamado de retorno anormal, é diferente ou não de zero. A "limpeza" é feita estimando um modelo no qual os retornos de uma ação são regredidos contra os retornos de um índice de mercado. Os coeficientes obtidos são então utilizados para calcular os retornos anormais, que são os valores reais menos o valor esperado. A ideia fundamental por trás desse método é a hipótese de mercados eficientes Fama (1970), que postula que o mercado acionário rapidamente incorpora ao preço da ação qualquer informação que se torna disponível.

Também é possível somar e tirar a média desses "retornos limpos" para várias empresas ao longo de uma janela de tempo e obter o retorno anormal médio cumulativo (Cumulative Average Abnormal Returns - CAAR). O CAAR nada mais é do que uma estimativa dos retornos fora do esperado para uma ou mais empresas em uma determinada janela de tempo ao redor de uma data, que pode ser diferente para cada empresa. Caso o programa de Diretrizes da OCDE tenha algum efeito sobre as empresas, espera-se que os retornos das açóes, e, portanto, os CAARs, sejam negativos perto da data da denúncia.

O tamanho da janela de tempo na qual o impacto do evento pode ser detectado depende do evento sendo investigado. Devido à rapidez com que os mercados processam informação, as janelas tendem a ser curtas. Além disso, o início da janela muitas vezes se dá antes da data da informação que temos à nossa disposição, por exemplo, a publicação de um artigo no jornal relatando o evento ou a passagem de uma lei. Se o mercado já tinha essa informação antes de ela ser registrada, isso já será refletido nos preços. Assim, por exemplo, o estudo de Flammer (2013), testando o impacto da publicação no Wall Street Journal de notícias sobre açôes de responsabilidade corporativa ambiental por parte de empresas, testou várias janelas em torno da data de publicação e concluiu que a janela de $[-1,0]$ era a mais relevante.

A figura 1 ilustra como os retornos anormais foram calculados. A janela de estimação, que contém os retornos utilizados na regressão, foi de $[-240,-40]$ dias antes da data do evento. Já a janela de análise foi de um dia antes até um dia depois da data do evento. Mais especificamente, os retornos anormais foram estimados com um modelo de mercado, onde $R_{i t}=\alpha_{i}+\beta_{i} R_{m t}+e_{i t}$, onde $R_{i t}$ é o retorno de uma dada empresa em um dia e $R_{m t}$ é o retorno de um índice de mercado em um dia. Os valores esperados são $\hat{R}_{i t}=\hat{\alpha}_{i}+\widehat{\beta}_{l} R_{m t}$. Finalmente, os retornos anormais são calculados como $A R_{i t}=R_{i t}-\hat{R}_{i t}$. 


\section{FIGURA 1}

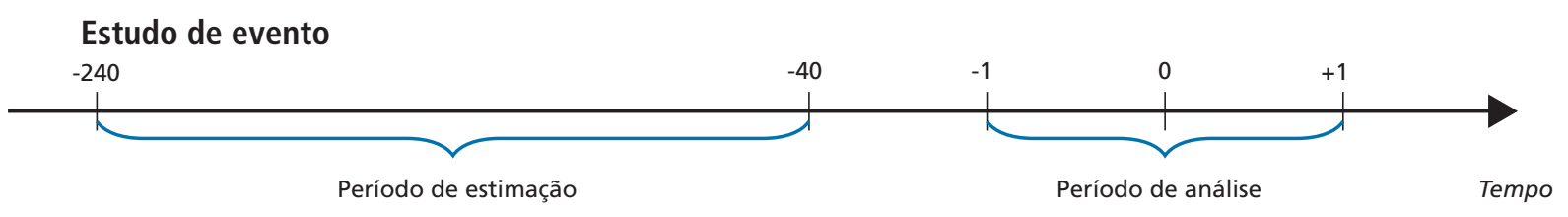

Elaboração dos autores.

Para determinar se os retornos anormais encontrados são estatisticamente diferentes de zero, a abordagem tradicional era um simples teste $t$. No entanto, com a popularizaçáo do método surgiram críticas à capacidade desse teste rejeitar a hipótese nula de ausência de efeito quando realmente há um efeito, ou seja, sua potência. Isso levou à proposição de diversos outros testes e a uma literatura discutindo qual é o teste mais apropriado em diferentes circunstâncias (Gelbach, Helland e Klick, 2013). Em geral, a literatura de estudos de eventos considera dois tipos de testes: paramétricos e não paramétricos. Enquanto testes paramétricos assumem que os retornos são normalmente distribuídos, os não paramétricos não dependem dessa hipótese. Para contornar a possibilidade de não normalidade dos retornos, este estudo utiliza os dois tipos de testes.

Alguns testes paramétricos tendem a rejeitar muito frequentemente a hipótese nula de que os retornos anormais são zero quando um evento causa um aumento na variância dos retornos (Boehmer, Masumeci e Poulsen, 1991). Assim, como teste paramétrico escolhemos o teste de Boehmer, que corrige tal problema. Já como teste não paramétrico, escolhemos o teste de Generalized Rank Test (Grankt). Além de não depender da hipótese de normalidade dos retornos e ter mais poder em amostras pequenas, esse teste é robusto a diversos problemas que retornos podem apresentar, como volatilidade induzida por um evento específico ou autocorrelação dos retornos anormais (Kolari e Pynnonen, 2011).

\section{RESULTADOS}

Para testar do impacto das denúncias, o primeiro passo foi estimar estudos de eventos individuais. O objetivo é verificar como os retornos anormais de cada uma das empresas se comportam quando uma denúncia é feita. Os CAARs são calculados individualmente com respeito à data de sua denúncia e usando o período de estimação [-240, -40] correspondente. A figura 2 plota os CAARs individuais com a data da denúncia no eixo x e o valor do CAAR no eixo $y$. O ticker da açáo marca o valor do CAAR para uma dada empresa e a cor é o setor ao qual pertence a empresa de acordo com o Yahoo Finance. A empresa como menor CAAR foi a de ticker K.TO, que corresponde a Kinross Gold Corporation. A instância que tratou dessa empresa, já citada, foi uma das que terminou em acordo entre alegante e denunciada. O segundo menor CAAR é da empresa Vale S.A. e se refere a uma denúncia feita em janeiro de 2020 acerca do acidente de Brumadinho. De todos os casos levados ao PCN brasileiro, esses são, portanto, os dois em que houve maior impacto negativo aos retornos das empresas na ocasião da denúncia.

A figura 2 não permite que seja concluído definitivamente se as denúncias das empresas brasileiras ao PCN sempre levam a impactos negativos significativos aos retornos, pois metade das empresas está acima do zero e a outra metade, abaixo. No entanto, enquanto quatro das empresas com CAARs positivos estáo a menos de 0,01 do zero, somente duas das empresas negativas estáo nessa situaçáo. 
Nos dois casos comentados anteriormente, as empresas sofreram fortes perdas de valor na janela próxima da data da denúncia.

FIGURA 2

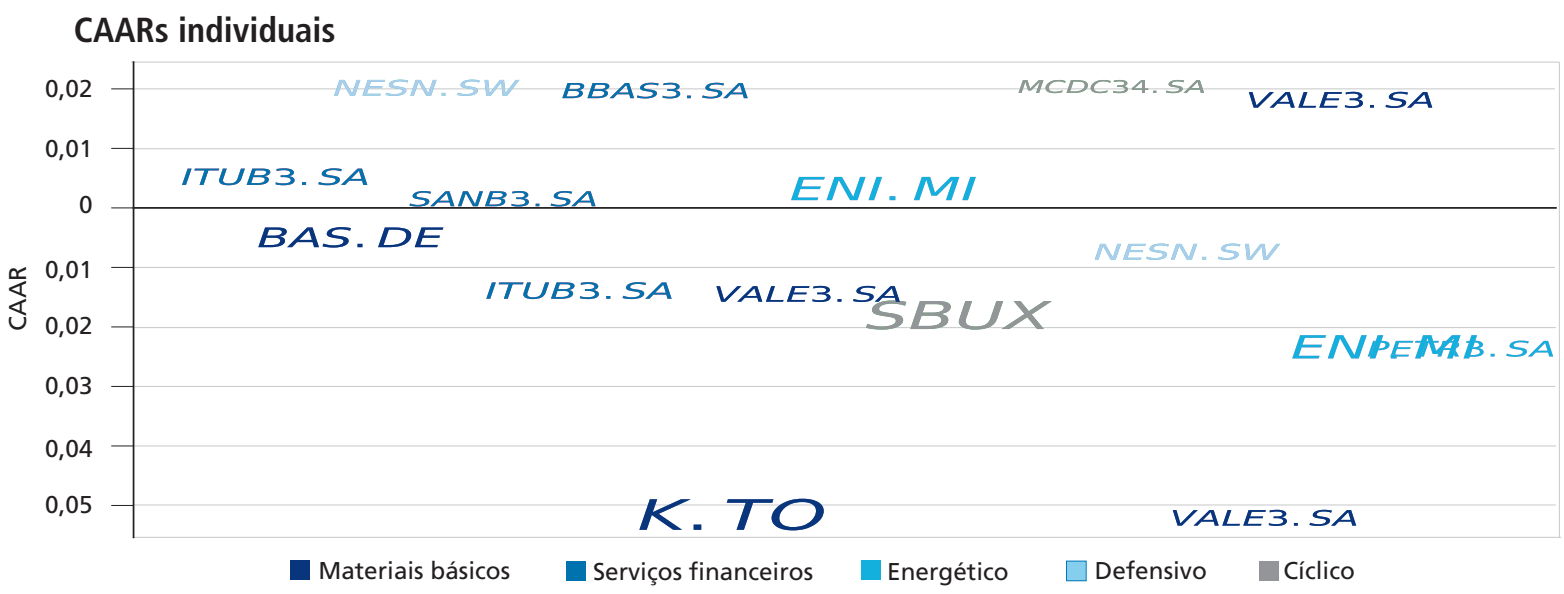

Elaboração dos autores.

Obs.: Relação dos tickers: PETR3.SA - Petrobras; ENI.MI - Eni S.p.A.; VALE3.SA - Vale S.A.; NESN.SW - Nestlé; MCDC34.SA - McDonald's; SBUX Starbucks; K.TO - Kinross Brasil Mineração; BBAS3.SA - Banco do Brasil; ITUB3.SA - Itaú Unibanco S.A.; SANB3.SA - Banco Santander S.A.; BAS.DE - BASF S.A.

Para cada caso, é importante distinguir o efeito do evento que gerou a denúncia do efeito da denúncia em si, pois é possível que o evento gerador da denúncia tenha ou não impacto nos retornos. Brumadinho certamente teve, mas um caso mais simples, como uma instância que trata da demissão de um único funcionário, provavelmente não teve efeito algum. Contudo, nosso interesse não está no evento gerador da denúncia: o que buscamos aqui é verificar se a denúncia para a OCDE tem algum impacto no retorno das açóes. Desse modo, o que chamamos de evento neste estudo não é o fato gerador da denúncia, mas a denúncia em si.

Assim, os impactos estimados são realizados exclusivamente na estreita janela de tempo em torno da denúncia. Os casos de que tratamos se iniciam com eventos que necessariamente antecedem a denúncia, no entanto, há tipicamente um hiato entre o evento original e a denúncia. Portanto, os impactos dos eventos originais já estariam precificados no valor das açôes por ocasião da denúncia, e o evento que nós estamos capturando é a denúncia e não o evento que gerou a denúncia.

Após estimar os CAARs individuais, partimos para a estimação de um estudo de evento contendo as doze empresas da amostra pós-revisão de 2011 para as quais foi possível obter dados, cujos resultados estão na tabela 2. Foram testadas diversas janelas diferentes e em todas elas o retorno anormal médio cumulativo foi negativo. Isso já é uma indicação de que, na média, a aplicação das Diretrizes no caso brasileiro tem um impacto negativo com potencial de sancionar o comportamento corporativo irresponsável. Para determinar se esses impactos negativos são de fato estatisticamente diferentes de zero, usamos os testes de Boehmer e de Grankt. A maioria das janelas na tabela 2 tem CAARs negativos, contudo, somente no caso da janela $[-1,1]$ podemos rejeitar a um nível de $5 \%$ de confiança que esse efeito seja zero usando o teste Grankt. Como são diversas empresas na amostra, cada qual com uma data diferente de denúncia, esse resultado, que está de acordo com os testes que realizamos com a amostra completa de todos os países em Mueller e Roviello (s.d.), dificilmente 
se daria aleatoriamente e podemos, portanto, aceitar que as denúncias têm na média um impacto negativo no lucro das empresas.

TABELA 2

Resultados do estudo de eventos

\begin{tabular}{lllcc}
\hline Janela & $N$ & CAAR & Boehmer (p-valor) & Grankt (p-valor) \\
\hline$[-1 ; 0]$ & 12 & -0.003 & 0.515 & 0.697 \\
{$[-1 ; 1]$} & 12 & $-0.012^{* *}$ & 0.118 & 0.042 \\
{$[-2 ; 0]$} & -0.001 & 0.747 & 0.319 \\
{$[-2 ; 1]$} & 12 & -0.009 & 0.670 & 0.611 \\
{$[-3 ; 1]$} & 12 & -0.007 & 0.613 & 0.534 \\
{$[-3 ; 3]$} & 12 & -0.011 & 0.509 & 0.736 \\
{$[-3 ; 2]$} & 12 & -0.015 & 0.399 & 0.191 \\
{$[-3 ; 0]$} & 11 & 0.001 & 0.892 & 0.567 \\
{$[-5 ; 3]$} & 12 & -0.008 & 0.842 & 0.860 \\
{$[-5 ; 5]$} & 12 & -0.015 & 0.920 & 0.734 \\
\hline
\end{tabular}

Elaboração dos autores.

Obs.: Significância estatística: * $10 \%,{ }^{*} 5 \%,{ }^{* * *} 1 \%$ pelo teste Grankt.

A janela curta em torno do evento está condizente com diversos resultados encontrados na literatura de estudos de evento. As magnitudes podem parecer pequenas, mas é importante lembrar que o Cumulative Abnormal Returns (CAR) é um retorno abnormal do preço das açóes de uma empresa cumulativo no período da janela. Já o CAAR é o CAR médio para todas as empresas da amostra. Assim, o CAAR de -0.012 estimado para a janela $[-1,1]$ significa a perda para os acionistas das empresas denunciadas da amostra de $1,2 \%$ do valor de mercado, na média, devido às denúncias. Como são empresas grandes, esse é um grande impacto. Nosso resultado é, portanto, forte evidência a favor da efetividade da aplicaçáo do programa de responsabilidade corporativa pelo PCN brasileiro nas empresas multinacionais no Brasil.

\section{CONSIDERAÇÕES FINAIS}

Dificilmente programas de responsabilidade social corporativa podem funcionar se dependerem exclusivamente de boas intençóes. Para que as empresas voluntariamente abram mão de comportamentos rentáveis que impóem custos à sociedade, é preciso que percebam que isto trará alguma contrapartida. Esta pode ser uma contrapartida positiva, como a noção de "se dar bem por fazer o bem" (doing well by doing good), em que o mercado premia a empresa por boa conduta. Pode ser também uma contrapartida de reduzir o risco de uma campanha de cancelamento ou boicote devido à percepçáo pelo mercado de alguma violaçáo por parte da empresa. Uma das grandes dificuldades de programas que visam fomentar empresas a adotar açóes de responsabilidade social corporativa é convencer as empresas que sua participação de fato pode gerar estas contrapartidas.

As Diretrizes da OCDE oferecem um grande arcabouço coordenado a nível global para fomentar maiores incentivos para que as grandes empresas multinacionais respeitem princípios de governança social corporativa. Duas décadas após seu início, o programa conta com vários casos de sucesso, mas ao mesmo tempo com uma proporçáo relativamente alta de recusas de engajamento no processo de mediação por empresas denunciadas, assim como casos nos quais nenhum acordo é alcançado. 
Além disso, há grande variabilidade na forma e na diligência com que o programa é implementado por PCNs de diferentes países.

Como o programa depende efetivamente da sua capacidade de impor custos às empresas que violam princípios de CSR, é essencial que exista uma percepção clara que esses custos são uma ameaça crível. $\mathrm{O}$ fato de muitas empresas simplesmente ignorarem as denúncias, se recusando a participar do processo de mediação e negociação, indica que provavelmente essa percepção ainda não está consolidada. Neste trabalho, nós usamos dados dos preços das açôes das empresas denunciadas em torno da data da denúncia para testar se, controlando pelas oscilaçóes gerais do mercado, esse choque específico à empresa tem um impacto negativo. Nosso foco aqui foi nas denúncias realizadas ao PCN brasileiro, e encontramos forte evidência de que, para essa amostra de empresas e denúncias, o programa tem na média um significativo impacto negativo, especificamente na janela $[-1,1] \mathrm{em}$ torno da data da denúncia. Certamente há muito espaço para aprimoramento nas Diretrizes e sua implementação, porém, este resultado mostra que ao menos o programa contém um elemento fundamental que qualquer programa desta natureza necessariamente deve possuir: a capacidade de realizar uma ameaça crível.

\section{REFERÊNCIAS}

BOEHMER, E.; MASUMECI, J.; POULSEN, A. B. Event-study methodology under conditions of event-induced variance. Journal of Financial Economics, n. 30, p. 253-272, 1991.

COZENDEY, C. M. Sobre aceder à OECD. Revista Brasileira de Comércio Exterior, n. 140, 2019.

DAVARNEJAD, L. In the shadow of soft law: The handling of corporate social responsibility disputes under the OECD guidelines for multinational enterprises. Journal of Dispute Resolution, n. 351, 2011.

FAMA, E. F. Efficient capital markets: a review of theory and empirical work. The Journal of Finance, n. 25, v. 2, p. 383-417, 1970.

FLAMMER, C. Corporate social responsibility and shareholder reaction: the environmental awareness of investors. Academy of Management Journal, n. 56, v. 3, p. 758-781, 2013.

FRIEDMAN, M. The social responsibility of business is to increase its profits. In: ZIMMERLI, W. C.; RICHTER, K.; HOLZINGER, M. (Eds.). Corporate ethics and corporate governance, Berlin: Springer, 2007. p. 173-178.

GELBACH, J. B.; HELLAND, E.; KLICK, J. Valid inference in single-firm, single-event studies. American Law and Economics Review, n. 15, v. 2, p. 495-541, 2013.

KOLARI, J. W.; PYNNONEN, S. Nonparametric rank tests for event studies. Journal of Empirical Finance, n. 18, v. 5, p. 953-971, 2011.

KOTHARI, S. P.; WARNER, J. B. Econometrics of event studies. In: ECKBO, B. E. Handbook of empirical corporate finance. North Holland: Elsevier, 2007. p. 3-36.

MELLO, F. D. C. The OECD enlargement in latin america and the Brazilian candidacy. Revista Brasileira de Política Internacional, n. 63, v. 2, 2020.

MUELLER, B.; ROVIELLO, F. Measuring the impact of the OECD Guidelines for responsible business conduct by multinational companies. Brasília: IPEA/CEPAL, s.d.

NIEUWENKAMP, R. The OECD Guidelines for multinational enterprises on responsible business conduct. DQ, n. 171, 2013. 
OECD - ORGANISATION FOR ECONOMIC CO-OPERATION AND DEVELOPMENT. Implementing the OECD Guidelines for multinational enterprises: the national contact points from 2000 to 2015. Paris: OECD, 2016.

Meeting of the OECD council at ministerial level: framework for consideration of prospective members. Paris: OECD, 2017.

Active with Brazil. Paris: OECD, 2018.

RUGGIE, J. G.; NELSON, T. Human rights and the OECD Guidelines for Multinational Enterprises: normative innovations and implementations challenges. Cambridge, MA: HKS, 2015. (Working Paper, n. 66).

THORSTENSEN, V. H.; CORTELLINI, A. C. N.; GULLO, M. F. A OCDE como fórum de governança das empresas multinacionais. São Paulo: FGV, 2018. (Working Paper, n. 488).

WEISSMAN, E. et al. Quantifying the costs, benefits and risks of due diligence for responsible business conduct: framework and assessment tool for companies. Columbia: OECD; SIPA, 2016. 



\title{
QUAIS CONTEÚDOS EMERGEM DAS INSTÂNCIAS ESPECÍFICAS RECEBIDAS PELO PCN BRASIL? REFLEXÕES A PARTIR DE ANÁLISES LEXICAIS
}

Luíza Mônica Assis da Silva²

\begin{abstract}
SINOPSE
Os pontos de contato nacional (PCNs) são os responsáveis pelo encaminhamento das instâncias específicas, um mecanismo não judicial de denúncia de violação das Diretrizes para Empresas Multinacionais, instituídas pela Organização para a Cooperação e Desenvolvimento Econômico (OCDE), que contribui para a reparação dos danos causados pelas companhias por meio do acordo entre as partes. Apesar de várias pesquisas apontarem a relevância desse instrumento para a promoção da conduta empresarial responsável (CER) no ambiente de negócios internacional, ainda são poucos os estudos acadêmicos que investigam os conteúdos dos documentos das instâncias específicas. 0 objetivo desta pesquisa foi conhecer os conteúdos discursivos do sumário das instâncias específicas recebidas pelo PCN Brasil no período de 2003 a 2020. Para isso, foi realizada a análise documental com apoio do software Interface de $R$ pour les Analyses Multidimensionnelles de Textes et de Questionnaires (Iramuteq), que processa análises lexicais. Os resultados apontam que o PCN Brasil tem seguido as recomendações da OCDE na forma como lida com as instâncias. Além disso, apesar de recente, o Manual de Procedimentos tem colaborado para uma maior transparência dos processos. Os achados também sugerem pouca interlocução com diferentes organizações da sociedade civil e que a fase dos bons ofícios (mediação) precisa ser fortalecida.
\end{abstract}

Palavras-chave: ponto de contato nacional; PCN Brasil; OCDE; conduta empresarial responsável; instâncias específicas.

\begin{abstract}
The National Contact Points (NCPs) are responsible for managing the specific instances, a non-judicial mechanism for denouncing violations of the Guidelines for Multinational Enterprises, established by the Organization for Economic Cooperation and Development (OECD), that contributes to repairing the damages caused by companies by means of agreement between the parties. Although several studies have pointed out the relevance of this instrument for the promotion of Responsible Business Conduct (CER) in the international business environment, there are still few academic studies that investigate the content of the specific instances' documents. The aim of this article is to apprehend the discursive content of the summaries of the specific instances received by NCP Brazil from 2003 to 2020. A documentary analysis is carried out using Iramuteq (Interface de R pour les Analyzes Multidimensionnelles de Textes et Questionnaires), a software that process lexical analyses. The results show that, regarding the way it deals with the specific instances, NCP Brazil has been following the OECD's recommendations. Furthermore, despite its recent introduction, the Manual of Procedures has contributed to greater transparency of processes. The findings also suggest little dialogue with different organizations of the civil society and that the phase of good offices (mediation) needs to be strengthened.
\end{abstract}

Keywords: national contact point; NCP Brazil; OECD; responsible business conduct; specific instances.

JEL: F53; M14.

Artigo recebido em 26/4/2021 e aprovado em 30/4/2021.

DOl: http://dx.doi.org/10.38116/bepi29art5

1. Este artigo foi financiado com recursos da Comissão Econômica para a América Latina e o Caribe (Cepal).

2. Doutora em psicologia social do trabalho e das organizações pela Universidade de Brasília (UnB) e mestre em Ciência Política pela UnB; docente e pesquisadora nas áreas de processos comunicacionais nas organizações e responsabilidade social das empresas; e consultora de comunicação organizacional. 


\section{INTRODUÇÃO}

As Diretrizes para Empresas Multinacionais ${ }^{3}$ fazem parte do documento Investimento Internacional e Empresas Multinacionais, elaborado pela Organizaçáo para a Cooperaçáo e Desenvolvimento Econômico (OCDE) e tratam da conduta empresarial responsável (CER). As Diretrizes funcionam, na prática, como mecanismo de soft law, e a adesão pelas empresas é voluntária. Entretanto, os países que aderem ao documento (incluindo membros e não membros da organização) assumem uma série de compromissos vinculativos e autorizativos relativos à promoção da CER.

Os temas ou capítulos do documento são abrangentes e tratam de: i) conceitos e princípios; ii) políticas gerais; iii) transparência; iv) direitos humanos; v) relaçôes laborais; vi) meio ambiente; vii) combate à corrupção, à solicitação de suborno e à extorsão; viii) interesses do consumidor; ix) concorrência; e x) tributação.

Desde a sua criação, em 1976, aconteceram cinco revisões das Diretrizes, em 1979, 1984, 1991, 2000 e 2011. As mudanças tiveram por objetivo esclarecimento e ampliação, com novos temas/capítulos, envolvendo questôes atinentes a meio ambiente, direitos humanos, direito do consumidor, combate à corrupção e compromisso da cadeia de fornecedores com a CER. As revisóes também inseriram procedimentos para a implementação das Diretrizes, para lidar com denúncias de violaçôes das Diretrizes (instâncias específicas) e para a elaboração de guias de due diligence, com o objetivo de tratar, mitigar e prevenir riscos de danos causados pelas empresas multinacionais (EMNs). Foram produzidos guias sobre diferentes setores econômicos, como vestuário e calçados, mineraçáo e financeiro, entre outros.

\section{OPERACIONALIZAÇÃO DAS DIRETRIZES}

\subsection{Os pontos de contato nacionais (PCNs)}

Todos os 49 países que aderiram às Diretrizes foram instados a criar a figura do PCN, destinando-lhe recursos humanos e financeiros necessários para o cumprimento de sua missão institucional, que é disseminar as Diretrizes junto às partes interessadas, operacionalizá-las e denunciar sua violação, propondo mecanismos extrajudiciais de mediação, bem como alternativas consensuais entre as partes e para a reparação de danos $(\mathrm{OECD}, 2020){ }^{4}$

Na revisão das Diretrizes ocorrida em 2000 definiu-se que os PCNs teriam em seu mandato um mecanismo não judicial para receber e mediar reclamações de violação das Diretrizes, denominado instância específica. ${ }^{5}$ Também foi criada pela OCDE uma base de dados aberta e informada pelos PCNs para publicizar as informaçôes sobre as denúncias recebidas, disponíveis na página da organização. ${ }^{6}$

\footnotetext{
3. Doravante denominadas Diretrizes.

4. A OCDE refere-se aos PCNs como "um mecanismo único de implementação da Responsabilidade Empresarial Corporativa com acesso a recursos em escala global e que fornece uma plataforma para mediação e conciliação" (OCDE, 2021, tradução nossa).

5. Neste texto utilizaremos os termos alegações de inobservância; reclamações; violações; instâncias específicas; denúncias; e alegações como sinônimos.

6. A base com informações de todos os PCNs está disponível em: <https://mneguidelines.oecd.org/database/>.
} 
A revisão das Diretrizes de 2011, implementada em 2012, promoveu, entre outras, mudanças nos procedimentos padronizados relativos às alegaçôes de violaçôes, visando garantir a uniformidade dos processos e condutas e maior transparência, visibilidade e previsibilidade de processos, independentemente do PCN em que as instâncias foram instauradas.

Os $48 \mathrm{PCNs}^{7}$ possuem diferentes arranjos institucionais, porém atuam de forma conjunta em redes de apoio e aprendizagem mútuas. O Secretariado da OCDE definiu uma série de requisitos para garantir a equivalência funcional entre os PCNs. Para assegurar o cumprimento de seu mandato em diferentes arranjos institucionais e estruturas, os seguintes critérios foram definidos: visibilidade, acessibilidade, transparência e accountability (figura 1). Ações e atividades são sugeridas de modo a cumprir esses critérios e são reportadas, anualmente, pelos PCNs ao Comitê de Investimentos e discutidas nos encontros entre os PCNs. Sáo também elementos de avaliação por pares (peer review) e de capacitaçóes promovidas pela OCDE.

\section{FIGURA 1}

\section{Critérios fundamentais para equivalência funcional}

\section{Core criteria for NCPS}
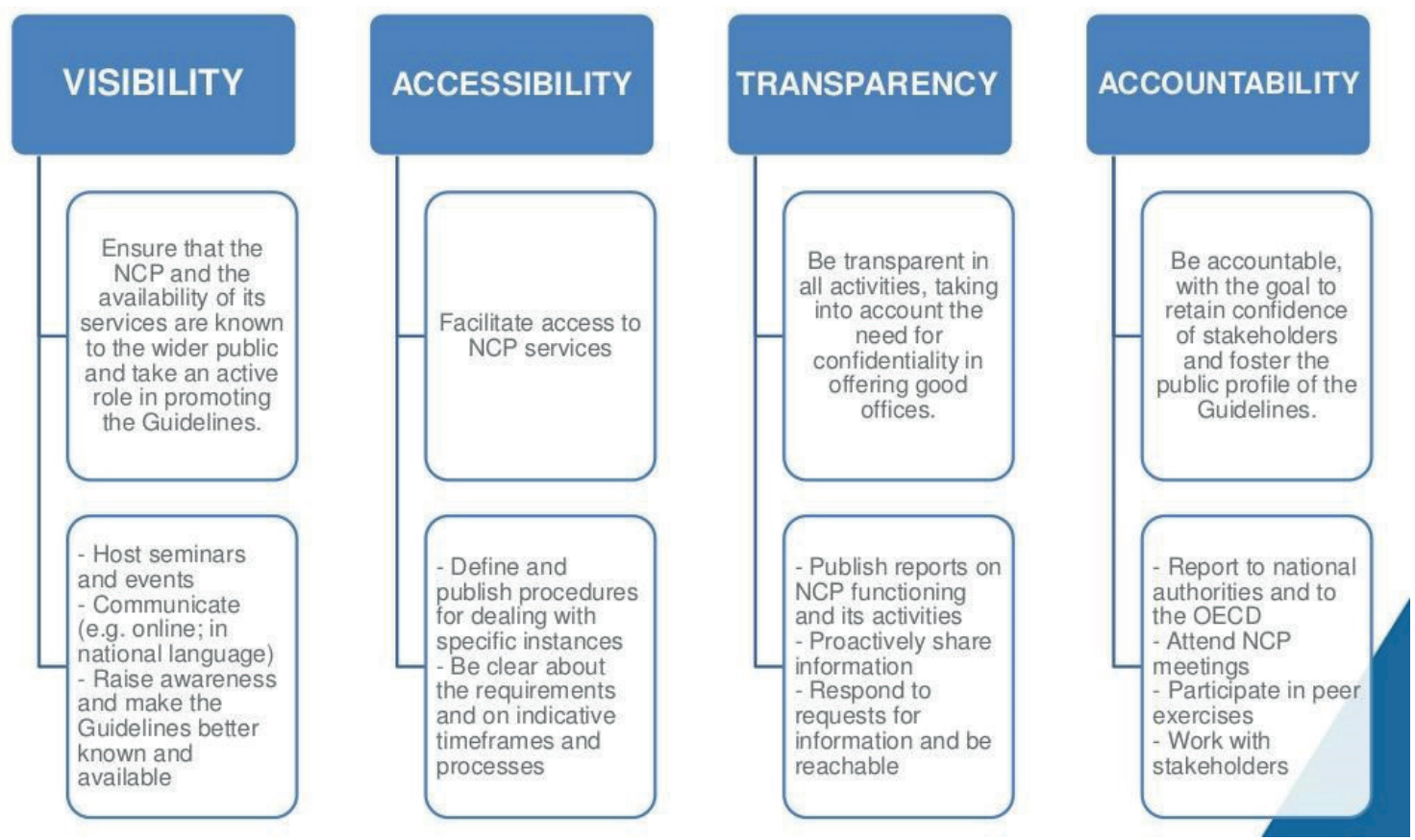

Fonte: OECD. Disponivel em: <https://www.slideshare.net/PamelaDuffin/ promoting-responsible-business-conduct-the-oecd-guidelines-for-multinational-enterprises-and-national-contact-points>. Acesso em: 27 mar. 2021.

Obs.: Figura cujos leiaute e textos não puderam ser padronizados e revisados em virtude das condições técnicas dos originais (nota do Editorial). 
O Brasil adotou uma estrutura interministerial de funcionamento para lidar com as instâncias específicas. ${ }^{8}$ Esse modelo tem a vantagem de dispor de uma variedade de especialistas entre os técnicos governamentais, sem necessidade de consulta externa, e pode ainda estimular a divulgação e a coerência com as Diretrizes entre variados órgãos do governo. Outro destacado benefício é estar menos sujeita a ser entendida como parcial ou tendenciosa por alguma das partes. Entre os desafios, está a ausência de conexóes com as partes interessadas, o que pode tornar mais difícil estabelecer relaçóes e conquistar confiança. Outro risco é o de que uma estrutura técnica, composta por vários órgáos e representantes, torne o processo de decisão mais lento e o consenso mais difícil (OECD, 2019).

\subsection{Instâncias específicas}

Uma das principais funçôes dos PCNs é receber e lidar com denúncias encaminhadas por indivíduos e/ou uma variedade de tipos de organizaçóes (empresariais, representativas de empresas, sindicatos de trabalhadores, organizaçóes não governamentais etc.), que são denominados alegantes, em contraposição às multinacionais denunciadas, as alegadas.

Os PCNs devem seguir procedimentos gerais recomendados pelo comitê, assim como aprovar um manual de procedimentos para instâncias específicas domésticas, preferencialmente elaborado e discutido por meio de consulta pública, permitindo, dessa forma, que seu mandato seja exercido. O documento deve apresentar a forma de lidar com as alegaçóes e deve estar de acordo com a estrutura e os recursos técnicos e financeiros disponíveis. O manual deve ser disponibilizado no idioma nacional e, preferencialmente, também em inglês e de modo on-line no site da agência.

A OCDE definiu três fases para as instâncias específicas a serem adotadas pelos PCNs, ainda que estes possam adaptá-las à sua realidade. São elas: avaliação inicial, bons ofícios e conclusão. A figura 2 descreve, sucintamente essas três fases.

Na primeira fase, chamada avaliaçáo inicial (initial assessment), o processo é analisado pelos requisitos e informaçóes iniciais do alegante (quem submete à instância específica) e da alegada (empresa denunciada). Adota-se um formulário padrão encaminhado a um relator que decide, com base nos princípios das Diretrizes, por sua aceitação ou rejeição. Quando não aceita, a alegação é automaticamente encerrada, e uma declaração deve ser publicada na página do PCN. Essa etapa tem duração prevista de três meses. O nome da empresa alegada é resguardado pela confidencialidade até a aceitação da instância específica.

A segunda fase, denominada bons ofícios (good offices), é a mais importante, pois busca a conciliação, o consenso e a reparação entre as partes e conta com um mediador. Recomenda-se que o prazo de duração dessa etapa seja de seis meses. A OCDE criou um guia sobre mediação e capacitaçóes específicas para essa fase, dada a complexidade da etapa.

A terceira fase, nomeada conclusão (conclusion), acontece quando: não há aceitação da denúncia; uma das partes decide não participar do processo; não é possível um acordo entre as partes; ou um

8. Outros arranjos institucionais possíveis são: i) Agência Única - o órgão é composto por um único indivíduo ou ministério ou um grupo de indivíduos de um mesmo ministério; ii) Agência Multipartite - o PCN é composto por um grupo de oficiais de governo e representantes das partes interessadas como governos, empresas, sindicatos e organizações da sociedade civil; iii) Grupo de Especialistas - no qual os membros são indicados pelo governo, mas são externos a este, sendo, portanto, estruturas independentes e não-governamentais que recebem recursos oficiais; e iv) Estruturas Híbridas - podem ser agências únicas ou múltiplas, compostas por especialistas (OECD, 2020). 
acordo é alcançado. Em caso de não aceitação, o PCN faz uma declaração e algumas recomendaçóes. Nas situaçôes em que as partes não entram em acordo ou quando este é celebrado, o PCN prepara o final statement com recomendaçóes e publica o resultado. A previsão de duração dessa fase é de três meses.

\section{FIGURA 2}

\section{Fases das instâncias específicas}

\section{Specific instances - process}

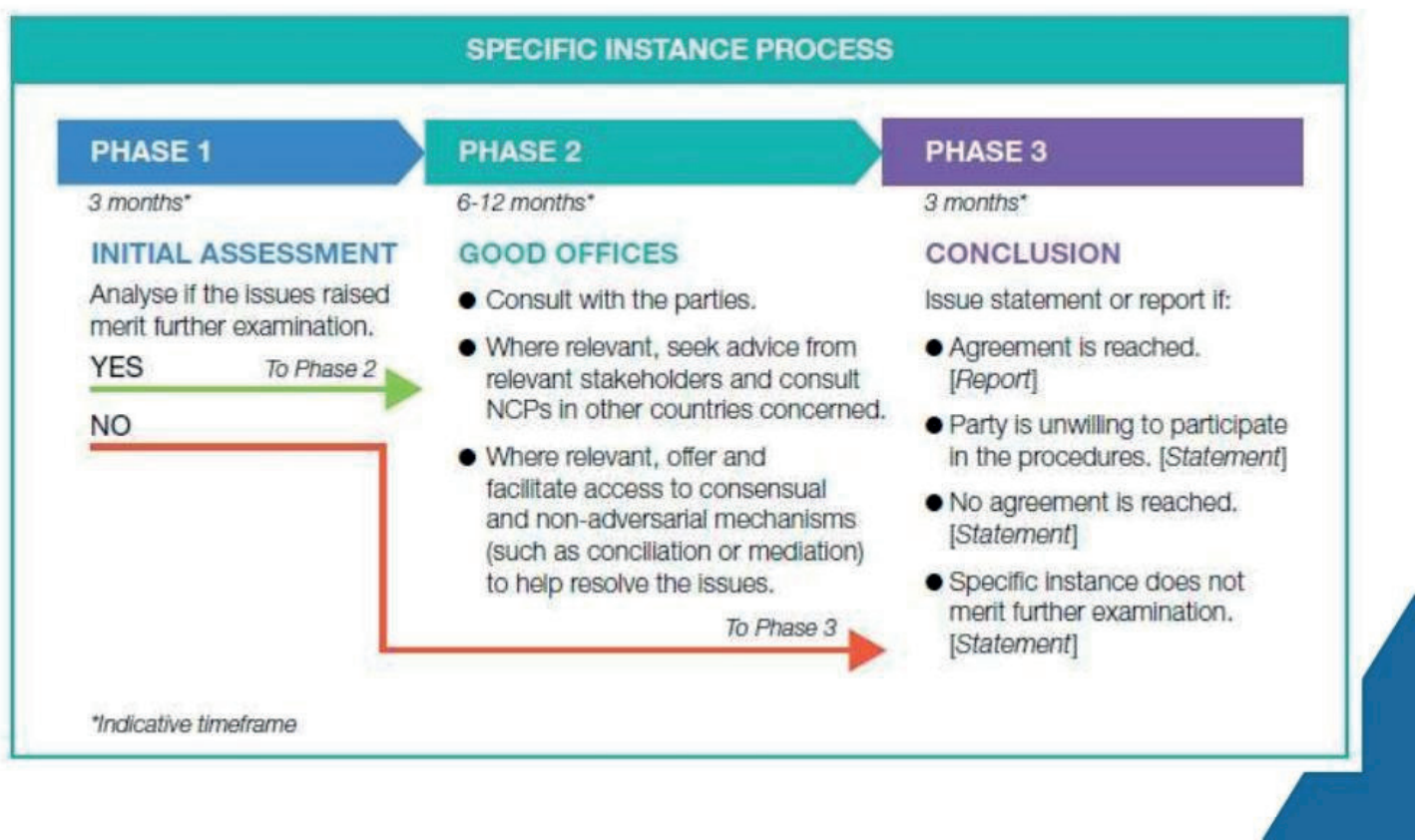

Fonte: OECD. Disponível em:<https://www.slideshare.net/PamelaDuffin/ promoting-responsible-business-conduct-the-oecd-guidelines-for-multinational-enterprises-and-national-contact-points>. Acesso em: 27 mar. 2021.

Obs.: Figura cujos leiaute e textos não puderam ser padronizados e revisados em virtude das condições técnicas dos originais (nota do Editorial).

O prazo recomendado para resolução é de doze meses, mas na maior parte das vezes acontecem atrasos por diferentes motivos - por exemplo, quando vários países estáo envolvidos, quando a denúncia se origina de um país que não aderiu às Diretrizes ou quando o processo de mediação é mais complexo (OECD, 2012).

Todas as fases contam com o apoio da OCDE na resolução de dúvidas e esclarecimentos das Diretrizes. Além disso, o Secretariado oferece capacitações para as equipes técnicas dos PCNs. As instâncias específicas podem envolver mais de um PCN. Em casos de denúncia de comportamento de uma empresa atuando em outro país, o PCN do país de origem do capital também participa do processo. Em casos mais complexos, dependendo da questáo e do porte da transnacional, podem ser envolvidos múltiplos PCNs e a coordenação da OCDE. 
Uma fase adicional, não obrigatória, é a de acompanhamento (follow up). O PCN busca supervisionar a implementação do acordo entre as partes e/ou as recomendaçôes que fizeram às empresas após a conclusão dos casos. Trata-se de uma etapa sem previsão de prazo, que fica a critério dos países.

Diante do exposto, podemos perceber que a OCDE, em conjunto com os PCNs, definiu uma série de regras e recomendaçóes para o tratamento das instâncias específicas e promoção de sua eficácia. Entretanto, existem críticas e ressalvas sobre a eficácia do mecanismo de reclamaçóes. A primeira delas refere-se a sua natureza voluntária e à ausência de sançôes. Para a organização não governamental (ONG) OECD Watch, ${ }^{9}$ as principais falhas do mecanismo se referem a sua relação com a sociedade civil e como instrumento de pressão para adoção da CER. Apenas 25\% dos PCNs emitem declaraçôes de que as empresas violaram as Diretrizes, o que impede a auditagem de possíveis investidores.

Apenas $10 \%$ atribuem consequências quando as empresas se recusam a participar de bons ofícios. Apenas um terço dos PCNs acompanha consistentemente as reclamaçóes concluídas para verificar se as empresas realmente implementaram os acordos e recomendaçóes. A mesma proporçáo dos PCNs não publicou regras de tratamento de reclamaçóes em inglês e em seu idioma nacional e alguns sequer têm regras de procedimento (OECD Watch, 2021).

Apenas um quarto dos PCNs atende às expectativas das organizações da sociedade civil (OSCs) quanto à transparência no processo de reclamação. Para a OECD Watch esses fatores são fundamentais para estabelecer expectativas claras sobre as empresas e vital para investidores que buscam aplicar recursos em empresas responsáveis (OECD Watch, 2021).

Também em relação à ausência de mecanismos de controle e pressão sobre as empresas, apenas $12 \%$ dos governos atribuem consequências às empresas que se recusam a se envolver de boa-fé no processo do PCN. No que diz respeito às comunicaçóes das alegaçóes, menos da metade dos PCNs têm um banco de dados com informaçóes. $\mathrm{O}$ acompanhamento acontece em apenas $33 \%$ dos casos para verificar se recomendaçôes e acordos foram cumpridos. Apenas $25 \%$ conseguem atender às expectativas de transparência da sociedade civil em relação ao processo de queixa. Apenas $50 \%$ dos PCNs publicam todas as declaraçóes em sua página web, apesar de esta ser uma regra vinculativa, e um pequeno grupo de $25 \%$ publica as avaliaçôes iniciais das denúncias (OECD Watch, 2021).

Esses dados revelam o desafio dos PCNs no cumprimento de seu mandato. Lembramos que mecanismos com características de autorregulação, ausência de sançóes e adesão voluntária podem ser ineficazes, principalmente em épocas de acirrada crise e desigualdade econômica e de poder entre os stakeholders, uma vez que a natureza das empresas está voltada para a busca do lucro, e sua participação é voluntária. Já autores como Backer (2009) destacam que, mesmo a "pequenos passos", o mecanismo das alegaçóes pode servir de ponto inicial para a mudança de comportamento das empresas e para a mudança na legislação interna dos países sobre a CER.

9. A OECD Watch é uma rede de organizações da sociedade civil que está presente em mais de cinquenta países. Composta por mais de 130 organizações, a instituição faz parte do Conselho Consultivo da OCDE, juntamente com a Trade Union Advisory Committee (TUAC) e a Business at OECD (BIAC). É interlocutora da sociedade civil para defender os interesses das ONGs na responsabilização e reparação de danos por parte das empresas. Busca defender os interesses de indivíduos nas relações de má conduta das empresas e realiza sua missão por meio do monitoramento dos mecanismos de implementação das Diretrizes e dos PCNs. 


\subsection{Como o PCN Brasil lida com as instâncias específicas}

O PCN Brasil foi criado por meio da Portaria no 92 do Ministério da Fazenda, de 12 de maio de 2003, permanecendo subordinado a esse ministério por quase dezesseis anos. Em 2016 passou a ter um funcionário com dedicação exclusiva (coordenador); e a partir de 2017, a contar regularmente com funcionários em tempo parcial, mas com mudanças frequentes no grupo. Desde 2020 conta com uma coordenação técnica composta por três servidores sêniores com elevada qualificação. Essa equipe é responsável por verificar se a alegação encaminhada por meio de formulário cumpre os requisitos de admissibilidade. Em caso positivo, o coordenador do PCN, após consultar o Grupo de Trabalho Interministerial (GTI), encaminha a instância para o relator mais adequado do colegiado interministerial.

Em 27 de junho de 2019, o governo brasileiro publicou o Decreto no 9.874, que instituiu o PCN Brasil e detalhou suas funçôes e atividades; número de representantes; composição interministerial; ${ }^{10}$ número de reuniôes e quórum de participação; membros titulares; funçôes do coordenador; além de listar outros órgáos competentes para seu assessoramento nas áreas de tributação, advocacia da União e meio ambiente. O PCN fica sediado no Ministério da Economia, sendo supervisionado pelo Comitê de Investimentos. Alguns meses depois, foi editada a Portaria Interministerial no 548 , que designa nominalmente os membros titulares e suplentes. Neste ano, foi aberto o processo de consulta pública para elaboração do Manual de Procedimentos para Instâncias Específicas, ${ }^{11}$ do qual participaram várias partes interessadas.

O Manual de Procedimentos, aprovado em 2020, é um documento extremamente importante, uma vez que apresenta com clareza as regras para lidar com as instâncias específicas e objetiva dar previsibilidade e transparência ao processo. Esclarece os requisitos necessários para apresentação das alegaçóes e explicita todas as etapas do processo. O documento está on-line na página do PCN Brasil e tem como anexo o formulário de submissão das instâncias que podem ser enviadas por e-mail (Brasil, 2020). Com a adoçáo do manual pode-se inferir que o processo de submissóes ficou mais claro, acessível, previsível e mais didático, o que pode levar ao aumento do número de submissóes. Após a publicação, o PCN Brasil recebeu seis novas denúncias no ano de 2020, das quais cinco foram aceitas e estão em curso. ${ }^{12}$

O órgão brasileiro busca cumprir as etapas definidas pela OCDE - avaliação inicial, bons ofícios e conclusão -, com algumas adaptaçóes e modificaçóes, mas buscando manter a equivalência funcional. Desse modo, cumpre a maioria dos requisitos vinculativos e autorizativos da agência, como ter um banco de dados com as alegaçóes de inobservância. ${ }^{13}$

10. A composição, colegiada, é a seguinte: três representantes do Ministério da Economia, sendo um representante da Secretaria Especial de Comércio Exterior e Assuntos Internacionais (coordenador), um representante da Secretaria Especial de Previdência e Trabalho e um representante da Secretaria Especial de Produtividade, Emprego e Competitividade. Os ministérios da Justiça e Segurança Pública, Relações Exteriores, Minas e Energia, Meio Ambiente, Controladoria Geral da União, da Mulher, Família e Direitos Humanos e o Banco Central do Brasil também possuem representantes.

11. Antes do manual havia a Resolução no 1/2012, com procedimentos para lidar com instâncias específicas, de acordo com o guia de procedimentos da OCDE.

12. Consulta realizada em abril de 2021.

13. 0 endereço do banco de informações é: <https://www.gov.br/produtividade-e-comercio-exterior/pt-br/assuntos/camex/pcn/produtos/ alegacoes-de-inobservancia/instancias-especificas-alegacoes-de-inobservancia-das-diretrizes-da-ocde>. 
Conforme o banco de dados disponibilizado no site, que apresenta o status das alegaçóes, o PCN Brasil tem conseguido lidar razoavelmente bem com a conclusão dos casos que recebeu de 2003 a 2020: 56\% foram concluídos; 25\% não foram aceitos; e 19\% estão em progresso (gráfico 1). Chama a atenção o percentual de $25 \%$ de não aceitas, mas que está abaixo do percentual para o conjunto dos PCNs no período 2000-2018, estimado em 36 \%, e do ano de 2019, que ficou em 60\%.

\section{GRÁFICO 1}

Status das alegações ao PCN Brasil (2003-2020)

(Em \%)

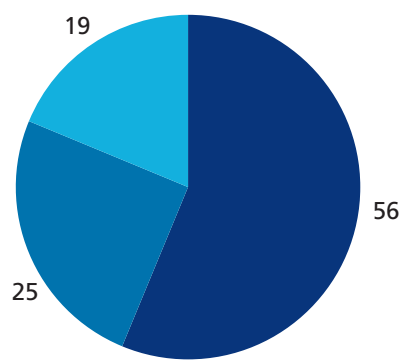

Concluído $\quad$ Não aceito Em progresso

Fonte: Banco de dados da OCDE sobre instâncias específicas. Disponivel em: <https://mneguidelines.oecd.org/database/>. Acesso em: 27 mar. 2021. Elaboração da autora.

O número de instâncias recebidas e o prazo de resolução não devem ser, todavia, os únicos parâmetros de efetividade dos PCNs. Como exemplo do primeiro caso, temos o PCN Japão, que apesar de ser bem avaliado pelos pares e de sólidas açôes de CER de suas multinacionais, têm relativamente poucas denúncias (OECD, 2012).

Os prazos, muitas vezes, espelham a complexidade das denúncias e a dificuldade em fechar acordo. Um dos casos concluídos em 2019 levou oito anos para ser finalizado (OECD, 2020). Por seu turno, PCNs que resolvem rapidamente as instâncias específicas podem ter interpretado de forma equivocada ou bastante restrita os capítulos das Diretrizes, o que implica em um alto grau de rejeição das denúncias e, consequentemente, rápida resolução. Poucas denúncias e rápida resolução também podem sugerir que o instrumento de alegaçóes de inobservância é pouco conhecido pelas partes interessadas e/ou que não tem a confiança dos alegantes.

As instâncias específicas têm sido pouco exploradas pela pesquisa acadêmica, apesar da diversidade de estudos técnicos produzidos pela OCDE. Na revisão de literatura empreendida para este trabalho nas bases científicas que compôe o Portal da Coordenação de Aperfeiçoamento de Pessoal de Nível Superior (CAPES) foram encontrados apenas três resultados para os termos national contact point specific instance. Um dos trabalhos refere-se, especificamente, à análise de estudos de caso, e os outros dois versam sobre corporaçôes e direito internacional. Os artigos sobre os PCNs são abundantes e ultrapassam 16 mil textos, nos últimos cinco anos, mas não abordam especificamente as alegaçóes. A busca para national contact point specific instance Brazil não obteve resultado, sendo, portanto, um indicativo de que o tema ainda náo foi devidamente abordado pelas publicaçóes científicas disponíveis no portal. 
O exame das instâncias específicas recebidas pelo PCN Brasil é central neste trabalho, dada a sua relevância no mandato dos PCNs para promoção e implementação das Diretrizes. Desse modo, com base nas recomendaçóes da OCDE e do guia de procedimentos, recentemente elaborado e publicado pelo PCN Brasil (em fevereiro de 2020), a análise das alegaçóes nos permitiria, em princípio, observar quais procedimentos são aplicados, de que forma e com quais resultados. De acordo com o exposto, e diante da carência de pesquisas sobre esse objeto, examinaremos, por meio de análises lexicais, os documentos relativos às instâncias específicas recebidas pelo PCN Brasil, com o objetivo de conhecer o conteúdo das alegaçóes de inobservância encaminhadas no período de 2003 a 2020.

\section{METODOLOGIA: ANÁLISES LEXICAIS DAS INSTÂNCIAS ESPECÍFICAS}

A OCDE estabelece que os PCNs disponibilizem no site todas as alegaçôes de inobservância recebidas, independentemente de seus status (aceita, não aceita ou concluída), bem como os textos das declaraçóes e declaraçôes finais. O PCN Brasil, por problemas em seu sistema de informação, não apresenta as declaraçôes finais, ${ }^{14}$ apenas parte das informaçóes relativas às instâncias, a saber:

- número da alegação de inobservância;

- data;

- alegado e alegante - em caso de não aceitação da alegação, o nome da empresa é mantido em confidencialidade;

- status;

- PCN responsável e de apoio, quando houver;

- descrição: identificação do alegante e do alegado (somente em caso de aceitação);

- $\quad$ tema(s) das Diretrizes violados;

- $\quad$ país de ocorrência;

- $\quad$ parte interessada;

- $\quad$ setor da alegação; e

- $\quad$ sumário contendo uma breve descrição da denúncia, envolvidos e a fase de andamento em que se encontra.

O site informa que

as Declaraçôes do PCN são públicas, com exceção das informaçōes para as quais uma das partes solicitar expressamente confidencialidade. Tais documentos são encaminhados às partes, à OCDE e aos PCNs dos países sedes das empresas multinacionais partes no processo e divulgados na página do PCN. ${ }^{15}$

14. Trata-se de documentos que devem ser públicos e conter uma visão geral do caso e a descrição do processo. Em caso de rejeição, descreve como a instância foi avaliada, sem apreciação de mérito. Em caso de aceitação sem acordo nos bons ofícios ou desistência de participação, enumera as questões levantadas, a assistência ofertada pelo PCN às partes, as posições das partes e possíveis razões pelas quais as empresas não chegaram a um acordo. Em caso de acordo, lista todos os procedimentos da mediação e assistência oferecida, compromissos acordados pelas partes e recomendações. O PCN Brasil escolheu em seu manual de procedimento não distinguir os documentos de conclusão entre declaração e declaração final, e sim usar apenas declaração final que deve ser aprovada pelo GTI-PCN.

15. Disponivel em: <https://bityli.com/DloQh>. Acesso em: 5 jan. 2021. 
Como não tínhamos acesso aos documentos relativos às declaraçóes finais, ${ }^{16}$ mais completos, optamos por analisar os resumos disponíveis por meio de análises lexicais informatizadas. Esse tipo de exame, mais objetivo, ${ }^{17}$ permite uma série de análises sobre a especificidade dos discursos do PCN Brasil, sintetiza com sucesso os principais conteúdos e a forma de trabalho do PCN.

Nas análises realizadas optamos por utilizar o Interface de R pour les Analyses Multidimensionnelles de Textes et de Questionnaires (Iramuteq), um software francês, gratuito, desenvolvido por Pierre Ratinaud, em 2009, que utiliza o ambiente estatístico do software R (Salviati, 2017). Entre outras funçôes, possibilita análises textuais pelo Método Reinert, um tipo de análise automática de discurso, desenvolvida por Max Reinert, em 1979.

O programa possibilita realizar análises lexicais em diferentes idiomas e desde 2013 tem sido utilizado em variadas pesquisas no Brasil. No caso das pesquisas documentais, pode ser utilizado com vantagens em relação à tradicional análise manual de conteúdo categorial temática, descrita por Bardin (2007). É uma ferramenta extremamente útil na análise de textos resultantes de entrevistas, grupos focais, redes sociais, questôes abertas de questionários, resumos em bases de dados, entre outros.

Basicamente, o programa sintetiza as informaçóes textuais e classifica as mais importantes, por meio de estatísticas como o $\chi^{2}$ (qui-quadrado) e análises fatoriais do corpus textual, ${ }^{18}$ realiza a classificação dos enunciados simples do texto em função da distribuição das palavras, identificando os vocábulos mais característicos. Além disso, o software permite acessar as representaçóes presentes em mensagens textuais, sem que haja perda de sua dinâmica e complexidade (Oliveira, Gomes e Marques, 2005). Por meio dos vocábulos mais característicos e da apresentação gráfica das análises fatoriais, é possível identificar diferentes lugares de fala, contradiçóes, bem como os temas característicos de um determinado gênero do discurso (Lima, 2008). A seguir, a título de exemplificação, apresentamos, resumidamente, a descrição dos processamentos do software na análise Reinert padrão que utilizamos.

O pesquisador prepara o corpus formatando o texto com a retirada de siglas, aspas, asteriscos, hifens, símbolos matemáticos e padroniza os vocábulos que devem ser analisados conjuntamente. Define os textos por meio de variáveis, por exemplo: fase da instância específica, alegante, alegada, relator etc. e as registra antecedidas por linhas com asterisco. Após o processamento, primeiramente, o programa divide o texto em unidades com três linhas em média, contendo até 250 caracteres para criação dos segmentos de texto. Esses segmentos são definidos com base na ordem em que aparecem no texto e na pontuação. Para isso, o texto é todo "picotado" em frases. Depois, é feita a contagem do radical de todas as palavras, o que possibilita o cálculo de coocorrências de palavras que pertencem ao mesmo grupo lexical. Após esses procedimentos é criado o dicionário de formas reduzidas.

As informações obtidas nessa análise inicial são apresentadas num relatório e referem-se: ao número de segmentos de texto que foram indexados pelo pesquisador; número total de palavras; número de vocábulos distintos; média de aparecimento de uma palavra; número de palavras que aparecem

\footnotetext{
16. No período de coleta de dados desta pesquisa (dezembro de 2020 a março de 2021) o link de acesso das declarações finais não disponibilizava os arquivos das declarações finais. Em abril de 2021, a página do PCN passou a disponibilizar as declarações finais mais recentes, mas não de todas as alegações submetidas ao órgão.

17. Em análises de conteúdo tradicionais, método manual, recomenda-se que as interpretações do pesquisador sobre os conteúdos de um texto passem pela supervisão de juízes que avaliam as categorias criadas em relação a: pertinência ou validade, exaustividade ou inclusividade, homogeneidade e, finalmente, consistência/fidedignidade.

18. É o conjunto dos textos construídos pelo pesquisador e que forma o objeto de interpretação. Em nosso caso, o corpus é formado pelo conjunto das alegações de inobservância das Diretrizes.
} 
apenas uma vez, denominadas hápax; número de formas antes da redução ao radical; número de ocorrências que definem os segmentos de textos; número de variáveis; porcentagem de riqueza do vocabulário; frequência mínima de palavras; número médio de palavras analisadas por segmento de texto; número de formas (palavras).

Numa segunda fase, é realizada a classificação descendente hierárquica $(\mathrm{CDH})$. Ainda nessa etapa, é obtido um dendrograma, com a divisão dos segmentos do texto em classes, nas quais existe uma grande homogeneidade de temas tratados e que apresenta o índice de relaçáo entre as classes, similaridade ou distância. É possível, nesse momento, identificar os principais eixos temáticos de um discurso.

Numa terceira fase, também resultante da $\mathrm{CDH}$, são apresentadas as análises fatoriais de correspondência sob a forma de gráficos que nos permitem localizar espacialmente as classes, sua proximidade, intersecçôes, distanciamento e oposição.

A quarta fase permite a interpretação dos dados por meio de um detalhamento das classes encontradas - seleção dos segmentos de texto mais representativos; listas das palavras com maiores $\chi^{2}$; palavras de presença significativa; palavras com ausência significativa; variáveis mais significativas por classe.

O Iramuteq nos permite fazer uma grande síntese do discurso, seus principais eixos, temas de cada classe exemplificadas com os trechos textuais mais significativos. Esses pequenos fragmentos textuais são representativos do discurso específico daquela classe e não de um segmento de texto, por exemplo, de uma única alegação, mas sim de um conjunto de alegaçóes que fazem parte de uma mesma categoria temática. É fundamental que seja descrito/transcrito de modo a dar maior clareza e objetividade à interpretaçáo realizada pelo pesquisador.

O material do corpus foi extraído do site do PCN Brasil, no botão Consultar as alegaçóes de inobservância já recebidas pelo PCN. Os documentos relativos à declaraçáo final e ao relatório das açóes em andamento náo estavam disponíveis nos respectivos links (período de dezembro de 2020 a 14 de março de 2020). Desse modo, optou-se por utilizar o "sumário" das alegaçóes da página, que contém informaçóes sobre a data de início, alegantes e alegadas e descrição da denúncia, possível conclusáo e/ou etapa de andamento.

A lista de alegaçóes contempla um total de quarenta instâncias relativas ao período 2003-2020, mas desse conjunto constavam os sumários de 38 documentos. ${ }^{19}$ As alegaçóes disponíveis foram integralmente lidas, copiadas do site e formatadas de acordo com os padrôes para análise do software.

Foram definidas as seguintes variáveis de análise para os segmentos de texto, de acordo com o status definido pelo PCN Brasil: i) concluída (*concluída), com total de 21 sumários; ii) aceita em curso (*aceitaemcurso), com total de dez sumários; e iii) não aceita (*naoaceita), num total de sete sumários.

19. Note que esses dados divergem do banco de dados da OCDE, que apresenta 33 alegações recebidas. Nesse período, o site do PCN Brasil apresenta 36 alegações (de 2018 a 2019 não houve recebimento) e recebeu mais seis em 2020. A página da OCDE que permite a pesquisa por cada PCN individualmente, mas como já advertimos, pode não estar atualizada, apresenta 32 instâncias. 


\section{RESULTADOS E DISCUSSÃO DAS ANÁLISES LEXICAIS}

Foram indexadas 38 alegaçóes que geraram, consequentemente, um corpus textual com 38 textos. Após o processamento, como resultado, obtivemos 283 segmentos de texto e 9.843 ocorrências. Destas, um total de 594 (6\%) aparecem uma única vez (hápax), o que mostra que o vocabulário náo é diversificado, mas refere-se a um discurso específico sobre os procedimentos e violaçóes sobre as Diretrizes e, possivelmente, relativos às violaçóes mais denunciadas. Foram identificadas 1.587 formas ou palavras.

\subsection{Classificação hierárquica descendente}

A figura 3 apresenta a classificaçáo hierárquica descendente. Tomando-se a parte de cima do dendrograma, podemos inferir que os textos sobre as alegaçóes de inobservância dividem-se em dois eixos principais, com base no cálculo de proximidade entre as classes, que mostra que elas tratam de temas relacionados. O primeiro eixo, composto pelas classes 1 e 2, denominamos Procedimentos do PCN Brasil. O segundo foi intitulado Diretrizes da OCDE para empresas multinacionais - quem denuncia e o que denuncia e é composto pelas classes 3, 4 e 5 .

\section{FIGURA 3}

Classificação hierárquica descendente das alegações: palavras mais representativas das classes (2003-2020)

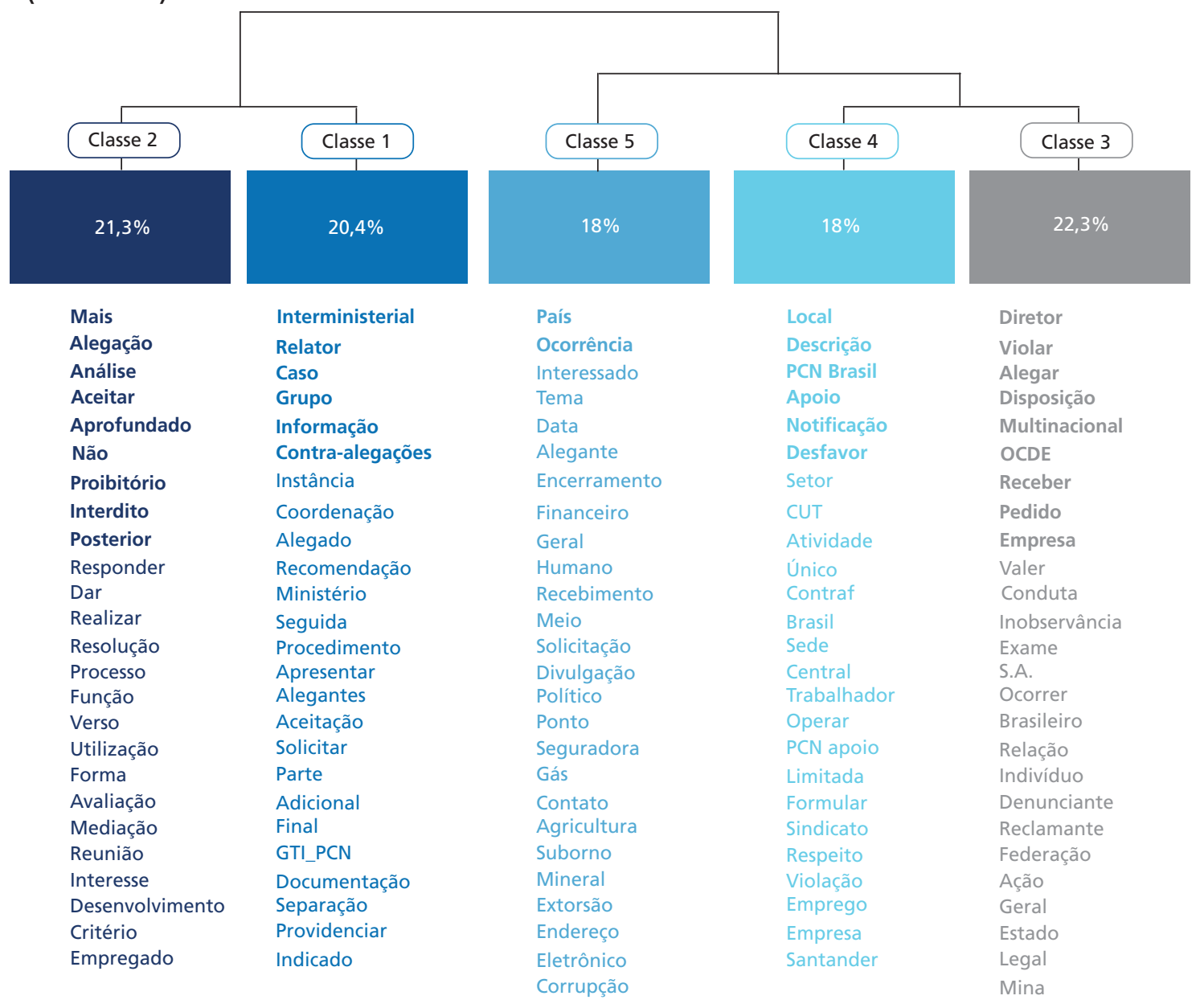




\subsubsection{Eixo 1: procedimentos do PCN Brasil}

A classe 2 é composta por 21,3\% do corpus. Entre as palavras mais representativas estão: mais, alegação, análise, aceitar, aprofundado, não, interdito, posterior, responder e realizar. A classe versa, principalmente, sobre os motivos para não continuidade e trata dos motivos de rejeição da denúncia prazo ultrapassado segundo as normas; análise mais aprofundada sobre a alegação; o alegante desistiu da ação; resolução judicial; encerramento judicial da empresa; e resolução direta entre as partes. A variável mais característica da classe é *nãoaceita. A seguir, a reconstituição do discurso da classe composto por algumas palavras e segmentos de maior $\chi^{2}$ que mostram que se refere às alegaçóes não aceitas. Cabe ressaltar que se trata de um resultado gerado pelo software, não refletindo uma alegaçáo específica ou trechos desta, podendo até incluir sentenças conflitantes em uma mesma classe.

A data de ocorrência deste evento não permite a aceitação da notificação, uma análise aprofundada ao não estar em acordo com a resolução que regulamenta o PCN Brasil. O PCN decidiu não aceitar esta notificação, após uma análise mais aprofundada. O PCN contatou a ONG, solicitando mais informaçôes, mas a $\mathrm{ONG}$ não as encaminhou. $\mathrm{O}$ alegante não manifestou interesse de que o caso tramitasse no Brasil. Durante a análise o relator verificou que houve transcurso de prazo superior a doze meses entre o conhecimento das demissōes e o recebimento da alegação.

A classe 1 compóe $20,4 \%$ do corpus e tem as seguintes palavras com maior $\chi^{2}$ : interministerial; relator; caso; grupo; informação; contra-alegações; instâncias; coordenação; alegaçôes; recomendação; ministério; seguida; procedimento; apresentar; alegantes; aceitação; solicitar, parte; adicional; grupo de trabalho; documentação; e providenciar. É formada por palavras características da variável *aceitaemcurso. Trata, principalmente, da fase de avaliação inicial, após a verificação do cumprimento dos requisitos de admissibilidade. Por se tratar de uma estrutura interministerial, essa palavra aparece em primeiro lugar. A definição da coordenação, a escolha do relator em função do ministério, os procedimentos seguidos para mais informaçôes dos alegantes e contra-alegaçóes e os documentos adicionais das partes alegantes e alegadas também aparecem no ranking. A seguir, um trecho representativo do discurso da classe.

A coordenação do PCN Brasil informou às partes alegantes que o grupo interministerial entendeu pela admissibilidade e aceitação do caso. As alegaçôes foram recebidas e encontram-se sob análise. Em seguida foi indicado o relator do ministério no âmbito do GTI, representante titular de Minas e Energia. Tendo em vista que a declaração final estipulou algumas recomendaçóes à empresa alegada, a coordenação do PCN estabeleceu o prazo de $1{ }^{\circ}$ de março para que sejam apresentadas informaçóes sobre a implementação de tais recomendaçôes. Após exame da documentação, o GTI decidiu por solicitar informaçôes adicionais conforme despacho do relator. O GTI condicionou a continuidade do procedimento à separação por instância por empresa alegada, o que foi providenciado pelas partes alegantes. Em seguida, as partes foram notificadas e a alegada apresentou suas contra-alegaçóes. Na comunicação informou que os documentos já foram fornecidos ao alegante e que não aceita participar dos procedimentos no âmbito do PCN Brasil. As alegaçóes foram recebidas e encontram-se sob análise.

Esse eixo mostra claramente o rito processual do PCN Brasil, de acordo com o manual de procedimentos, que se institucionaliza a partir da chegada das alegaçóes, as diferentes etapas do processo de avaliação inicial e as regras de prosseguimento, bem como o cuidado nas análises processuais e para a não aceitação da denúncia. Pode-se verificar que as normas procedimentais têm sido seguidas, como também as orientaçôes da OCDE, de publicizar as açôes e consubstanciá-las. Percebe-se que, de fato, o GTI acompanha os processos por meio do relator e das decisóes colegiadas. 


\subsubsection{Eixo 2: Diretrizes da OCDE para empresas multinacionais: quem denuncia e o que denuncia}

No segundo eixo (classes 3, 4 e 5), as classes 3 e 4 estão mais próximas (ver figura 3). As palavras mais representativas da classe 3 são: diretrizes; violação; alegação; disposição; multinacional; OCDE; receber; pedido; empresa; Vale; inobservância. Aqui os destaques são as Diretrizes; os tipos de violação; e as empresas multinacionais, principalmente as estrangeiras, que violam as Diretrizes e, em menor escala, as multinacionais com sede no Brasil. O vocabulário pertence aos elementos discursivos da OCDE (vocabulário próprio da agência). Há também a referência ao trabalho em conjunto com outros PCNs, como pode ser visto no trecho a seguir.

Em maio de 2004, o PCN brasileiro recebeu um pedido de exame da ONG Movimento dos Atingidos por Barragens (MAB) alegando que a Usina Canabrava violou as disposiçóes de meio ambiente das Diretrizes no Brasil por meio da construção de uma barragem e de deslocamento das populaçóes locais. Esse PCN recebeu notificação de OSCs de que a Van Oord, empresa multinacional holandesa, tinha violado as disposições de políticas gerais de divulgação de direitos humanos e de meio ambiente das Diretrizes em Pernambuco, Brasil. De acordo com o reclamante, a supracitada empresa multinacional ao instalar-se em Gravataí criou um sindicato paralelo, o sindicato dos trabalhadores nas indústrias metalúrgicas mecânicas e de material elétrico de Gravataí. O PCN Alemão recebeu um pedido de exame de um indivíduo alemão alegando que uma empresa multinacional tinha violado as disposiçóes de políticas gerais e de direitos humanos das diretrizes em Bangladesh (tema: políticas gerais e direitos humanos; país da ocorrência Bangladesh: alegante: manifestação individual; setor: manufatura).

A classe 4 tem por principais vocábulos: local; descrição; PCN Brasil; apoio; notificação; desfavor, CUT (Central Única dos Trabalhadores), CONTRAF (Confederação Nacional dos Trabalhadores do Ramo Financeiro). Essa classe, muito próxima em conteúdo da anterior, refere-se mais claramente ao PCN Brasil e aponta notificaçóes em desfavor das empresas feitas pela CUT e sindicatos. Lembramos que parte significativa das alegaçóes recebidas pelo PCN Brasil refere-se a relaçóes de emprego e empresariais (17). A seguir, um trecho extraído da classe.

Nestlé grupo de ex-representantes Purina setor e local perda de emprego no setor manufatureiro no Brasil PCN Brasil. Descrição alegação notificada por grupo de ex-distribuidores relativa às atividades de empresa multinacional suíça no Brasil tema Políticas Gerais. Basf e CUT setor e local emprego e relaçōes do trabalho no Brasil, responsável PCN Brasil, descrição: alegação formulada pela CUT em representação dos sindicatos componentes da rede de trabalhadores na Basf América do Sul em desfavor da empresa Basf.

A classe 5, que representa 16\% do corpus, tem como palavras principais: país; ocorrência; interessado; tema; data; alegante; encerramento; financeiro; geral; direitos humanos; recebimento; solicitação; divulgação; políticas; agricultura; suborno. Fala sobre alegantes e alegados, do perfil dos alegantes (lembramos que são majoritariamente sindicatos, como indica a classe 4); e o tema de violação das Diretrizes em que a multinacional incorreu. $\mathrm{O}$ trecho a seguir apresenta as frases e palavras de maior $\chi^{2}$. Mais uma vez, lembramos que não se refere a uma alegação específica, foi montado a partir do relatório do software, com as palavras mais representativas em negrito.

Data de recebimento 21 de agosto de 2018, país de ocorrência Brasil parte interessada N.A. setor Agricultura. Alegante sindicato do setor das empresas financeiras e de seguros. Concluída, data de encerramento 04. 10. 2013.Tema Políticas Gerais, Divulgação, Direitos Humanos e Meio Ambiente. Alegante Fórum Suape, Conectas Direitos Humanos, Both Ends, Colônia de Pescadores do Município de Cabo de Santo Agostinho. País da ocorrência Brasil, alegante grupo setor manufatureiro. De acordo com os denunciantes a supracitada empresa multinacional incorreu em conduta qualificada como recall branco, temas: políticas gerais, divulgação, emprego e relações do trabalho, combate à corrupção, solicitação de suborno, extorsão e interesses do consumidor. 
Resumidamente, o segundo eixo trata das Diretrizes, sintetizando o perfil das denúncias levadas ao PCN Brasil e respondendo às perguntas sobre as alegaçóes de inobservância: quem denuncia, de onde denuncia, o que denuncia, porque denuncia e quando ocorreram as denúncias.

As análises lexicais corroboram as informaçóes constantes na base de dados da OCDE sobre o PCN Brasil. Nela, os temas mais denunciados de inobservância são, em número de reclamaçóes: políticas gerais (19); emprego e relaçôes empresariais (17); direitos humanos (12), divulgaçáo (9); meio ambiente (9); conceitos e princípios (5); combate ao suborno, solicitação de suborno e extorsão (1); defesa do consumidor (1). Em relação aos setores econômicos, os mais denunciados são: manufatureiro (10), financeiro (8) e de mineração (6). ${ }^{20}$

Em relação aos aceites de violaçóes recebidas, temos o seguinte quadro em relação ao status das denúncias: $56 \%$ foram concluídas; $25 \%$ não foram aceitas; e $19 \%$ estão em progresso. Lembramos que as concluídas não significam que as empresas que participam do processo de bons ofícios/mediação façam acordo, tampouco que modificam sua política depois de participar do processo. Entrevistas e relatórios anuais mostram que o processo de acompanhamento é muito recente no PCN Brasil, sendo também um conteúdo que não aparece na análise lexical, apesar de só termos tido acesso ao sumário das alegaçôes e não às declaraçôes finais e outros possíveis relatos de acompanhamento.

O perfil dos alegantes/partes interessadas mostra que os sindicatos são os que mais denunciam violaçóes, seguidos das ONGs. Os sindicatos, em sua maioria, são ligados à CUT e não a outras centrais sindicais, mostrando que esse tipo de organização é o que mais conhece e acessa esse instrumento, principalmente nos primeiros anos de sua implementação.

Em relação às ONGs, o corpus contém a informação sobre ONGs locais e uma ligada aos direitos humanos (Conectas Direitos Humanos), que apresenta várias alegaçóes. Não aparecem violaçôes advogadas por grandes e tradicionais ONGs brasileiras ligadas a questóes das Diretrizes, como Instituto Ethos de Responsabilidade Social, Instituto AKATU para o Consumo Consciente, IDEC, IBASE, ABONG e várias outras especializadas nos temas das Diretrizes. Esse quadro pouco diverso pode revelar um baixo grau de interlocuçáo com organizaçóes da sociedade civil, haja vista que o PCN Brasil é interministerial, mas não multipartite e não conta com um conselho consultivo, como recomenda a OCDE.

\subsection{Análise Fatorial de Correspondência (AFC)}

Em relação à AFC, podemos destacar a oposição das classes em diferentes partes do plano fatorial. Temos claramente as alegaçóes em curso (classe 1) versus alegaçóes não aceitas (classe 2). O eixo das classes 3, 4 e 5 é mais descritivo dos conteúdos mais expressivos das alegaçôes. Podemos observar, na figura 4, as seguintes oposições no Plano Fatorial, cuja forma lembra um coração. 
FIGURA 4

\section{Plano fatorial das alegações (2003-2020)}

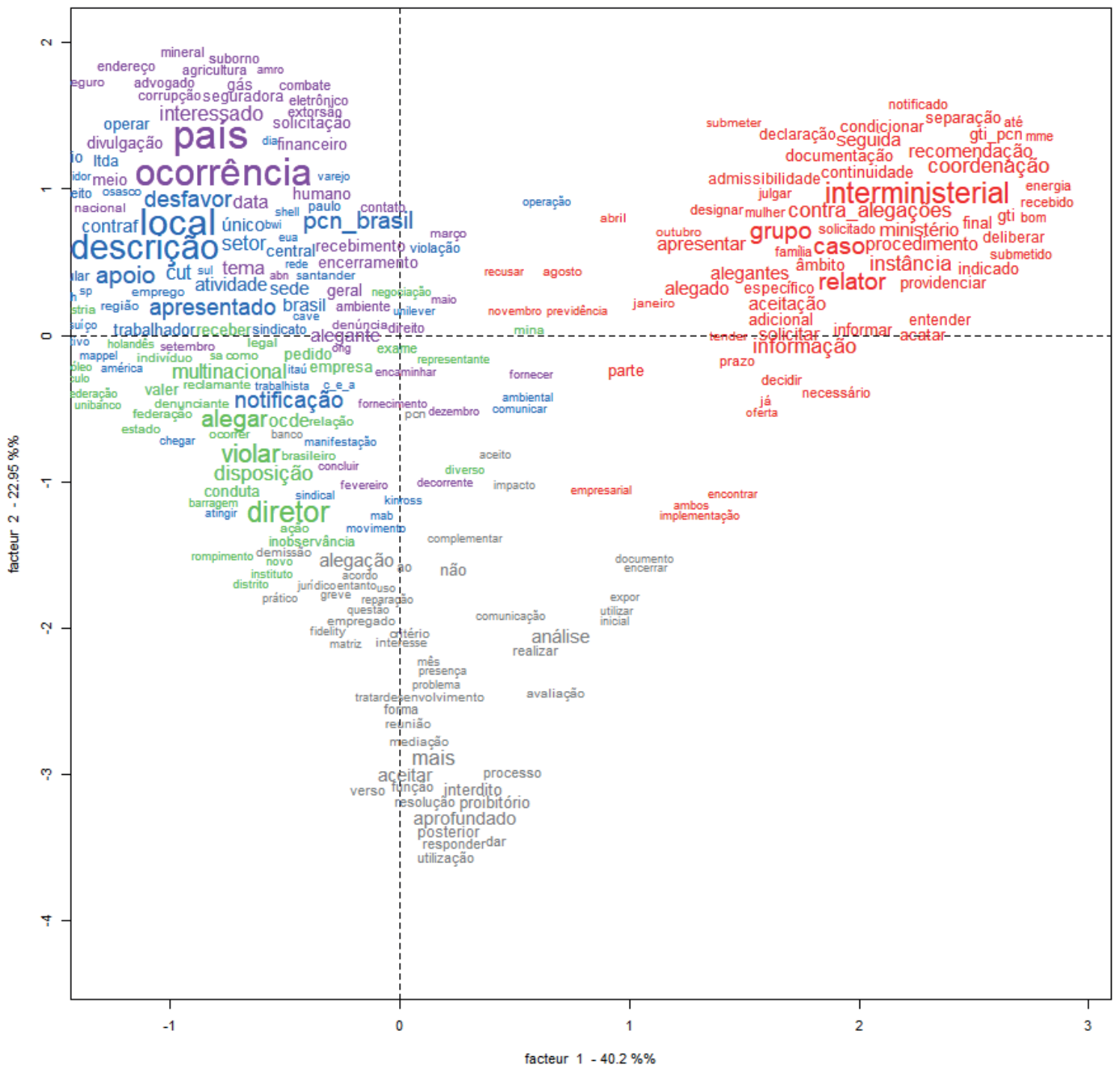

Elaboração da autora.

Obs.: Figura cujos leiaute e textos não puderam ser padronizados e revisados em virtude das condições técnicas dos originais (nota do Editorial).

\subsubsection{Primeira oposição: instâncias aceitas/em andamento versus não aceitas}

Quando observamos a classe 1(em vermelho), no plano direito superior, a maioria dos vocábulos mais representativos nitidamente se opóe aos da classe 2 (em cinza), no plano direito e esquerdo inferiores. Isso pode ser mais bem visualizado se olharmos as classes 1 e 2 na diagonal e nos atentarmos para as palavras mais significativas de cada classe. 


\subsubsection{Segunda oposição: em andamento versus concluídas ${ }^{21}$}

A classe 1 (em vermelho) está visivelmente em oposição ao agrupamento das classes 3 (verde), 4 (azul) e 5 (lilás), assim como à classe 2 (cinza), que concentra vocábulos típicos das alegaçôes não aceitas. Isso pode indicar a diferença de fases das submissóes das mais recentes para as mais antigas e já encerradas. Foram verificadas, no período da análise, nove instâncias abertas, sendo seis de 2020. No plano superior direito, o discurso contempla mais vocábulos da fase inicial do processo e do novo manual de procedimentos. Então teríamos na AFC as mais recentes (em andamento) em contraposição às já concluídas, que representam $81 \%$ das submissôes feitas ao PCN Brasil.

Um importante conteúdo da análise lexical é relativo a vocábulos e segmentos de texto relacionados ao processo de mediação, tais como bons ofícios, boa-fé, consenso, negociação, solução, remediação, reparação, entre outros. Como já foi dito, tivemos acesso apenas ao sumário, mas, sintomaticamente, as palavras mediação e acordo aparecem sem muito destaque, ${ }^{22}$ e no eixo do plano fatorial relativo às alegaçôes não aceitas. Isso é um forte indício de que poucas instâncias chegam a essa fase e estabelecem acordos. Desse modo, é necessário fortalecer a fase dos bons ofícios por meio de estratégias de comunicação e, principalmente, de persuasão. ${ }^{23}$

A leitura dos sumários revela que, das 38 alegaçóes, apenas quatro chegaram à fase da mediação e, desses casos, em apenas uma houve acordo - Kinross Canadense e Associação de Moradores de Paracatu, de 2013, em que a empresa se comprometeu a reparar casas dos três bairros objeto da alegação. Essa instância, inclusive, tornou-se um dos casos escolhidos no documento comemorativo dos 20 anos dos PCNs, intitulado National Contact Points for Responsible Business Conduct: Providing access to Remedy - 20 years and the road ahead (OECD, 2020).

Outro ponto que destacamos é que a recusa ou desistência das empresas e, por vezes, de alegantes e partes interessadas, sugere ainda a falta de conhecimento sobre o processo de mediaçáo, de sua natureza extrajudicial, dialógica, conciliatória e que pode trazer benefícios para as partes. Pode indicar ainda o medo que as empresas têm de prejudicar sua imagem e reputação, ao continuar as açóes, e também que não têm confiança no processo ou a preferência por processos judiciais. Para os outros agentes, como sindicatos e ONGs, pode também significar que optam por manter seus papéis e canais tradicionais (judiciais, legais e de confronto) a que já estão acostumados, em vez de buscar ou esperar por uma solução conciliatória nos termos do processo de mediação.

\section{CONSIDERAÇÕES FINAIS}

O objetivo desta pesquisa foi conhecer o conteúdo e as categorias temáticas (classes) das instâncias específicas recebidas pelo PCN Brasil no período de 2003 a 2020.

Os resultados apontam que esse discurso pode ser sintetizado em dois eixos. O primeiro, denominado Procedimentos do PCN Brasil, trata dos processos relativos ao andamento das denúncias,

21. Lembramos que concluídas podem ser as instâncias sem acordo (uma das partes não se engajou no processo), no qual a mediação foi alcançada, as não aceitas e as que resolveram a questão judicialmente. No PCN Brasil temos $25 \%$ de não aceitas, pequeno engajamento das empresas e alegantes que desistem do processo.

22. 0 tamanho da palavra relaciona-se com aos valores de frequência e $\chi^{2}$.

23. Note-se que a baixa participação na etapa de bons ofícios não acontece apenas no Brasil, mas em todos os PCNs. Desse modo, devem ser planejadas estratégias de comunicação e engajamento em conjunto com a OCDE, os PCNs e stakeholders. 
da análise cuidadosa para aceitação ou rejeição, do cumprimento das orientações da OCDE e do acompanhamento do GTI e das decisóes colegiadas da agência.

O segundo eixo, intitulado Diretrizes da OCDE para Empresas Multinacionais: quem denuncia e o que denuncia, nos permite conhecer o trâmite das instâncias. Pudemos conhecer os alegantes, os temas mais denunciados, as razóes das reclamaçóes e os locais onde ocorreram as violaçóes.

O plano fatorial apresenta as oposiçóes das classes (aceitas versus não aceitas; e concluídas versus em andamento) e os vocábulos característicos de cada classe. Os resultados indicam que o PCN Brasil tem seguido as recomendaçôes da OCDE na forma como lida com as instâncias. Além disso, apesar de recente, o manual de procedimentos tem colaborado para uma maior transparência e sistematização dos processos.

Os achados desta pesquisa indicam, no entanto, fraca interlocução com organizaçôes da sociedade civil e denúncias majoritariamente advindas de sindicatos. A fase dos bons ofícios precisa ser fortalecida, uma vez que um número reduzido de empresas aceitou participar da mediação, e isso se reflete na ausência lexical de vocábulos referentes aos acordos mútuos.

Entre as limitaçóes deste trabalho está o fato de termos analisado apenas o sumário dos processos e não os documentos relativos às declaraçôes finais. Quando o sistema de tecnologia de informação responsável pelo lançamento desses documentos na base de dados vier a disponibilizá-los, análises mais completas poderáo ser feitas. Com um corpus formado por documentos mais completos, sugere-se também examinar o impacto do manual de procedimentos nos processos relativos às reclamaçóes a partir de 2020. Outrossim, realizar estudos de caso com as multinacionais que aceitaram participar dos processos de mediação e com as partes (alegantes e alegados) que se recusaram a fazê-lo.

\section{REFERÊNCIAS}

BACKER, L. C. Rights and accountability in development (RAID) $v$ das air and global witness $v$ afrimex: small steps towards an autonomous transnational legal system for the regulation of multinational corporations. Melbourne Journal of International Law, May, 2009, v.10, n. 1, p. 258(50).

BARDIN, L. Análise de conteúdo. Lisboa: Edições 70, 2007.

BRASIL. Ministério da Economia. Ponto de contato nacional do Brasil. Manual de procedimentos para instâncias específicas. Brasília: ME, 2020. Disponível em: <https:/www.gov.br/produtividade-e-comercioexterior/pt-br/assuntos/camex/pcn/produtos/formularios/pcn-manual-de-procedimentos-para-instancias.pdf $>$. Acesso em: 5 jan. 2021.

LIMA, L. A articulação "themata-fundos tópicos": por uma análise pragmática da Linguagem. Psicologia: Teoria e Pesquisa. v. 24. n. 2. 2008. p. 243-246.

OECD - ORGANISATION FOR ECONOMIC COOPERATION AND DEVELOPMENT. The OECD guidelines for multinational enterprises. Japanese NCP: peer learning and review. Paris: OECD, 2012. Disponível em: <https://www.oecd.org/daf/inv/mne/JapaneseNCPReview.pdf>.

Annual report on the OECD guidelines for multinational enterprises 2018. Paris: OECD, 2019. Disponível em: <http://mneguidelines.oecd.org/2018-Annual-Report-MNE-Guidelines-EN.pdf>.

National contact points for responsible business conduct providing access to remedy - 20 years and the road ahead. Paris: OECD, 2020. Disponível em: <http://mneguidelines.oecd.org/NCPs-for-RBCproviding-access-to-remedy-20-years-and-the-road-ahead.pdf>. 
OECD responsible business conduct. Paris: OECD, 2021. Disponível em: $<$ http://mneguidelines. oecd.org/ncps/NCPs-at-20/>. Acesso em: 24 fev. 2021.

OECD WATCH. NCP evaluations. Amsterdam: OECD Watch, 2021. Disponível em: <https://www. oecdwatch.org/indicator/>. Acesso em 27 fev. 2021.

OLIVEIRA, D. C.; GOMES, A. M. T.; MARQUES, S. C. Análise estatística de dados textuais na pesquisa das representaçóes sociais: alguns princípios e uma aplicação ao campo da saúde. In: MENIN, M. S. S; SHIMIZU, A. M. (Orgs.). Experiência e representação social: questôes teóricas e metodológicas. São Paulo: Casa do Psicólogo, 2005. p. 157-200.

SALVIATI, M. E. Manual do Aplicativo Iramuteq (versão 0.7 Alpha 2 e R Versão 3.2.3). Planaltina: [s.n.], 2017. Disponível em: <http://www.iramuteq.org/documentation/fichiers/manual-do-aplicativo-iramuteqpar-maria-elisabeth-salviati>. 



\title{
TRATADOS BILATERAIS DE INVESTIMENTO: CONCEITOS, POTENCIAIS IMPACTOS E TENDÊNCIAS FUTURAS
}

\author{
Ignácio Tavares de Araújo Júnior ${ }^{1}$
}

\begin{abstract}
SINOPSE
Os tratados bilaterais de investimento (TBIs) são um conjunto de normas que regulamentam os investimentos estrangeiros privados de um país em outro. 0 objetivo do TBI é prover a segurança desejável a investidores externos para estimular a entrada de investimento externo direto (IED). Este artigo faz uma revisão de uma série de trabalhos teóricos que analisam o efeito do TBI sobre o IED. De acordo com a literatura a respeito do tema, não há consenso sobre o sinal e a magnitude do impacto do TBI sobre o IED, havendo evidências apontando efeito positivo, ausência de efeito e até mesmo sugerindo impactos negativos. As tendências futuras para os TBls dão maior clareza para termos como expropriação indireta; buscam meios de resolver eventuais disputas sem a necessidade de recorrer a tribunais internacionais; e procuram evitar que, para atrair mais IED, os Estados façam concessões que entrem em conflito com objetivos de políticas domésticas que visem ao desenvolvimento sustentável.
\end{abstract}

Palavras-chave: tratados de investimento; investimento externo direto (IED).

\begin{abstract}
The bilateral investment treaties (BITs) are a set of rules that regulate private foreign investment from one country to another. The BITs aim to provide desirable security to foreign investors in order to stimulate the inflow of foreign direct investment (FDI). This article reviews a series of theoretical papers that analyze the effect of BITs on FDI. According to the literature on the subject, there is no consensus on the sign and magnitude of the impact of BITs on FDI. There are evidences suggesting a positive effect, lack of effect and even indicating negative impacts. Future trends for TBIs clarify terms such as indirect expropriation; try new ways to resolve potential disputes without the need to resort to international courts; and seek to avoid making concessions that conflict with domestic policy objectives aiming sustainable development.
\end{abstract}

Keywords: investment treaties; foreign direct investment (FDI).

JEL: F21; F23; N4.

Artigo recebido em 15/12/2020 e aprovado em 27/1/2021.

DOI: http://dx.doi.org/10.38116/bepi29art6

\section{INTRODUÇÃO}

O ingresso de investimentos externos diretos (IEDs) pode ser fonte de geração de empregos e, mais importante ainda, expôe a economia local a novas tecnologias, contribuindo para o aumento da produtividade e o crescimento econômico. Trabalhos teóricos e empíricos sugerem alguns determinantes para o ingresso de IED, tais como tamanho e qualidade do mercado, estabilidade macroeconômica, estoque de infraestrutura e dotação de fatores de produção (Blonigen, 2005). Parte da literatura sobre o tema também destaca a qualidade das instituiçôes locais, representada em grande parte pela garantia

1. Professor do Departamento de Economia da Universidade Federal da Paraíba (DE/UFPB); pesquisador do Laboratório de Economia e Modelagem Aplicada (Lema) da UFPB; e doutor em economia pelo Programa de Pós-Graduação em Economia da Universidade Federal de Pernambuco (Pimes/UFPE). E-mail: <ignacio.tavares@gmail.com>. 
de diretos de propriedade, como um importante atributo do país para ser destino de investimentos (Bénassy-Quéré, Coupet e Mayer, 2007; Buchanan, Le e Rishi, 2012). Diante do receio de ter seus ativos expropriados, as empresas tenderiam a direcionar seus investimentos para países em que os direitos de propriedade são respeitados, normalmente os já desenvolvidos. A partir do final da década de 1950, países em desenvolvimento, muitos deles apresentando instituiçóes frágeis ou sem a reputação dos países já desenvolvidos, encontraram, nos tratados bilaterais de investimento (TBIs), uma forma de sinalizar seus compromissos com os direitos de propriedade de investidores externos para então atrair mais IEDs. Ao mesmo tempo, os países desenvolvidos viram nos TBIs uma forma de proteger os investimentos de suas empresas em países com instituiçóes menos consolidadas.

Os TBIs são um conjunto de normas que regulamentam os investimentos estrangeiros privados de um país em outro. Espera-se que contribuam para a previsibilidade, a estabilidade e a transparência nas relaçóes de investimento, além de ajudar a retirar as disputas de investimentos do campo da ação diplomática de Estado para Estado para o âmbito da resolução de controvérsias baseada em leis. Os TBIs podem ajudar a melhorar os marcos regulatórios e institucionais dos países, reduzir os riscos para os investidores estrangeiros e, de forma mais geral, contribuir para melhorar o clima de investimento (UNCTAD, 2015). Acredita-se que TBIs contribuam para o aumento de IED porque indicariam que os partícipes do acordo estáo dispostos a assumir compromissos críveis de respeito aos direitos de propriedade em razáo dos elevados custos ex post resultantes do náo cumprimento das cláusulas do tratado. O TBI, além de elevar o IED entre as partes, também sinalizaria para outros países que é seguro investir naqueles que se comprometem com os termos do TBI.

Este artigo busca investigar os resultados que esses tratados podem gerar em termos de atração de novos investimentos e benefícios para a sociedade. Para alcançar esse objetivo, será realizada uma revisão da literatura teórica sobre o tema a fim de compreender em que circunstâncias os efeitos dos TBIs sobre o IED podem ficar mais evidentes. Por fim, seráo apresentadas as novas tendências para esse tipo de acordo. O Brasil, apesar de ter assinado alguns TBIs nos anos 1990, apenas em 2015 ratificou seu primeiro acordo bilateral de investimento. É importante destacar que aqueles acordos não foram ratificados devido ao receio do Congresso Nacional brasileiro a respeito de possíveis incertezas jurídicas que os TBIs poderiam trazer para o país, além de uma eventual perda de soberania notadamente sobre a adoção de políticas de interesse público que poderiam afetar direta ou indiretamente empresas estrangeiras no país (Cozendey e Cavalcante, 2015; Morosini e Xavier Junior, 2015). Para um país que necessita de maior integração internacional, conhecer as novas tendências e os benefícios e riscos inerentes a um acordo como esse pode contribuir para a formulaçáo de acordos futuros que resultem em alocaçóes de investimento mais eficientes e contribuam para o desenvolvimento do país.

A disponibilidade de dados macroeconômicos sobre os fluxos de IED tem permitido avaliar se de fato os TBIs geraram seu principal efeito esperado, que é um incremento do IED entre os países participantes do acordo. Parte dos resultados dos trabalhos empíricos já realizados evidencia esses efeitos positivos, inclusive condicionando-os a um controle da possível endogeneidade (os TBIs seriam mais frequentes nos países que já recebem mais IED), ao setor de destino do investimento (indicando se há custos irrecuperáveis nos investimentos) e a aspectos institucionais do país, sugerindo que os TBIs não são substitutos, e sim complementares às instituiçôes locais (Egger e Pfaffermayr, 2004; Neumayer e Spess, 2005; Tobin e Rose-Ackerman, 2011; Colen, Persyn e Guariso, 2016). Em contrapartida, alguns 
estudos não evidenciam tal efeito causal e apontam canais por meio dos quais a celebração de um TBI pode até mesmo reduzir o ingresso de IED (Rose-Ackerman e Tobin, 2005). ${ }^{2}$

Os custos decorrentes dos mecanismos de solução de controvérsias ocupam lugar central nas críticas aos TBIs, motivando inclusive o encerramento de vários deles. A perda de soberania seria também uma possível desvantagem de se firmar um acordo de investimento nos moldes tradicionais, em que eventuais litígios são julgados em tribunais internacionais nos quais as especificidades das leis locais não têm validade (Neumayer e Spess, 2005; Elkins, Guzman e Simmons, 2006). Além disso, com receio de serem citados em algum tribunal de arbitragem internacional, os países que são membros do acordo perdem a liberdade de implementar políticas de interesse público, mas que afetam o retorno do investimento externo realizado no âmbito do TBI. Diante de tais críticas, os novos TBIs apresentam mecanismos de solução de controvérsias com menor risco, exigem maior transparência nos tribunais de arbitragem e deixam claro que os objetivos de desenvolvimento sustentável e outros objetivos sociais náo podem ser penalizados pelos termos do TBI. ${ }^{3}$

Além desta introdução, o artigo conta com quatro seçôes. Na segunda, são apresentados conceitos relacionados aos TBIs. Em seguida, discorre-se sobre aspectos teóricos embasando a relação positiva entre fazer parte do TBI e o ingresso de IED. Críticas aos TBIs comumente encontradas na literatura também são apresentadas nessa seção. $\mathrm{Na}$ quarta seção, exibem-se algumas tendências para os TBIs, tendo em vista as vantagens e desvantagens de fazer parte desse tipo de acordo. A última seção traz algumas conclusóes.

\section{TBIS: HISTÓRICO E CONCEITOS FUNDAMENTAIS}

Um TBI é um acordo entre dois países que estabelece o tratamento dispensado ao investimento realizado num dos países por uma empresa do outro país. Como destacado no relatório de UNCTAD (2000), em 1959 foi assinado o primeiro TBI, no seu formato atual, entre a Alemanha Ocidental e o Paquistão. Inicialmente, os TBIs eram ratificados entre países exportadores de capital (países desenvolvidos) e países importadores de capital (países em desenvolvimento). O interesse do país desenvolvido no TBI era garantir segurança jurídica adicional para os investimentos de suas empresas além do que era oferecido pelas leis do país em desenvolvimento, cuja motivação em participar do TBI era utilizar o acordo como meio de atrair mais investidores externos. Todavia, esse padrão mudou desde o final da década de 1980 e, especialmente, nos anos 1990, à medida que os países em desenvolvimento e as economias em transição começaram a assinar diversos TBIs entre si. Como resultado, TBIs eram ratificados mesmo entre países importadores de capital (UNCTAD, 2000). No decorrer dos anos, os TBIs se tornaram o principal instrumento para reger as relaçóes de investimento entre países de diferentes níveis de desenvolvimento econômico (UNCTAD, 2015).

Um marco importante na história dos TBIs foi a criação do Centro Internacional para a Arbitragem de Disputas sobre Investimentos (International Centre for Settlement of Investment Disputes - ICSID) em 1965. O ICSID é uma instituição intergovernamental abrigada no Banco Mundial estabelecida sob um tratado multilateral, a Convenção sobre a Solução de Disputas sobre Investimentos entre Estados e Nacionais de Outros Estados. O ICSID tem fornecido instrumentos para a resolução de controvérsias sobre investimentos entre investidores e Estados anfitrióes. Outro

2. A literatura empírica sobre os efeitos dos TBIs sobre o IED é revisada no artigo Investimento Externo Direto na América Latina: o papel dos acordos de investimento, publicado neste volume.

3. Disponível em: <https://bit.ly/3d2Xs0k> 
exemplo de uma instituição de arbitragem internacional é a Comissão das Naçóes Unidas para o Direito Comercial Internacional (United Nations Commission on International Trade Law - Uncitral), que disponibiliza um conjunto de normas que podem regular o processo de arbitragem, mas não atuam como instituição de arbitragem (UNCTAD, 1996). As disputas entre investidor e Estado relacionadas ao TBI são decididas por um tribunal que normalmente consiste em três árbitros, cada uma das partes nomeando um deles, e o presidente é escolhido em comum acordo entre as partes.

Como mostra o gráfico 1, na década de 1990 e no início dos anos 2000, o número acumulado de TBIs cresceu expressivamente. Atualmente, existem 2.911 TBIs assinados e 2.353 ratificados (in force). Contribuiu para esse aumento a competição por investimentos externos entre países. Naçóes como a China e a Índia, com enorme potencial tanto como destino quanto como fonte de IED, expandiram rapidamente o número de tratados. Nesse período de elevado crescimento no número de acordos, o Brasil assinou alguns TBIs, mas nunca os ratificou, em razão de objeçóes, por parte do Congresso Nacional, aos termos dos acordos assinados, que, no entender do Congresso, concediam privilégios ao investidor estrangeiro em detrimento do nacional e limitavam a autonomia regulatória do Estado (Cozendey e Cavalcante, 2015; Morosini e Xavier Junior, 2015).

\section{GRÁFICO 1}

\section{Evolução do número de acordos de investimento no mundo} (Em 1 mil)

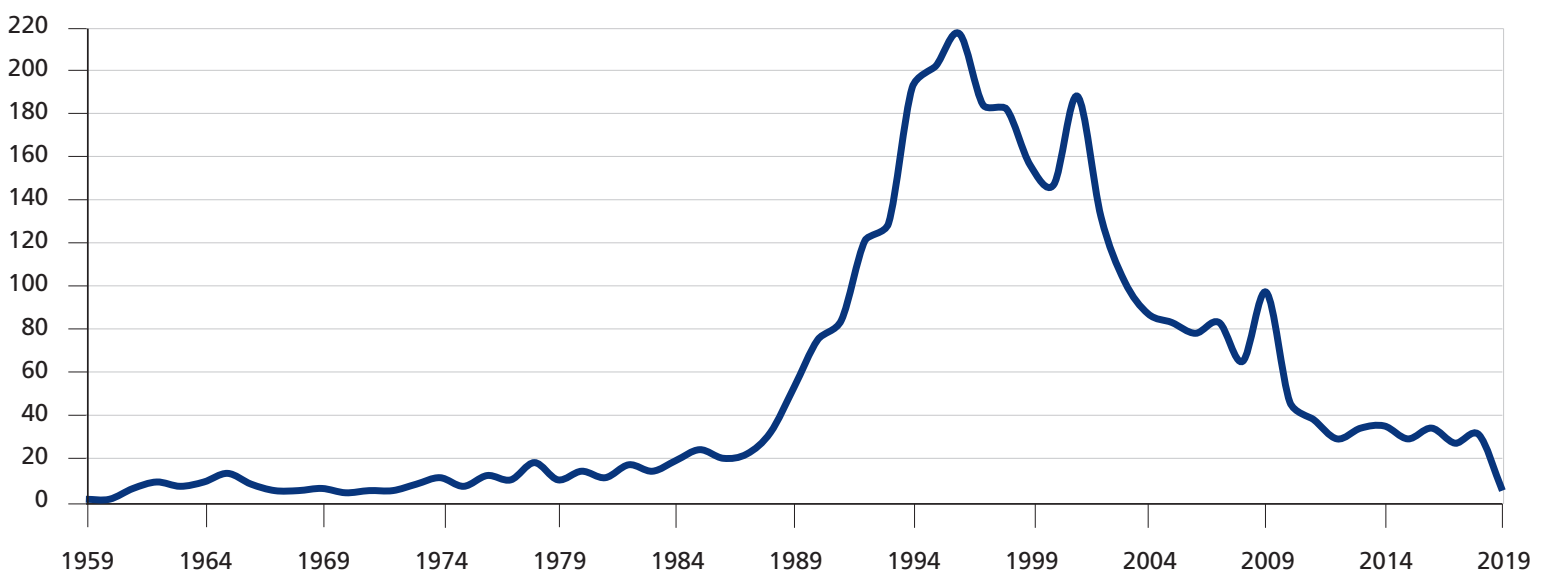

Fonte: UNCTAD (2019).

Muchlinski (2009) descreve os elementos usualmente encontrados num TBI. O TBI apresenta uma seção de apresentação do acordo (preâmbulo) em que podem ser encontrados seus propósitos e os setores da economia que se pretende beneficiar pelo tratado. Definem-se, a seguir, os investimentos que serão cobertos pelo tratado, incluindo não apenas ativos físicos mas também propriedade intelectual. Os termos do acordo também limitam investidores que podem participar dele, tornando-o restrito, por exemplo, àqueles que investem no país receptor e que possuem alguma ligaçáo de nacionalidade e residência no país contratante. Outro aspecto importante do acordo são os padróes do tratamento dado à empresa investidora. Para garantir que o investidor estrangeiro tenha tratamento equitativo e não discriminatório, em alguns casos, pode-se definir que será dispensado um tratamento ao menos táo bom quanto o dado às empresas domésticas ou um equivalente ao melhor tratamento dado a uma empresa estrangeira já estabelecida no país. Um componente-chave do acordo é a seção sobre as cláusulas de resolução de controvérsias. São esses termos que em tese garantem a proteção do direito 
de propriedade à luz do direito internacional e a compensação em caso de expropriação. Cláusulas de solução de controvérsias em TBIs podem ser divididas entre as que lidam com disputas entre os países quanto à observância e à interpretação do tratado e aquelas que lidam com disputas entre o investidor e o país anfitrião. Em ambos os casos, pode haver previsão no acordo para resolver as controvérsias através de negociação direta. Caso a negociação não solucione a discordância, parte-se para algum tribunal de arbitragem, com maior frequência seguindo as recomendaçóes do ICSID. Havendo pré-consentimento total, os TBIs concedem aos investidores estrangeiros o direito de apresentar, unilateralmente, pedidos de arbitragem internacional diretamente contra os governos, sem primeiro utilizar os recursos jurídicos internos do país.

\section{TBIS: ASPECTOS TEÓRICOS}

A seguir, serão apresentados aspectos teóricos sobre por que o TBI é capaz de atrair investimentos para um país e em que circunstâncias esse impacto pode ser potencializado. É importante destacar que os TBIs podem trazer custos para os países-membros e que esses custos podem tornar a adesão ao TBI menos atrativa ou mesmo resultar em seu cancelamento. Nesta seção, também serão exibidos alguns pontos negativos dos TBIs.

\subsection{Como o TBI estimula o IED}

De acordo com Guzman (2009), Neumayer e Spess (2005), Hallward-Driemeier (2003) e Kohler e Stähler (2016), a adoção de acordos bilaterais de investimento é resposta para problemas de hold-up (comportamento oportunista) ou de inconsistência dinâmica nos países em desenvolvimento tentando atrair IEDs. Nos problemas de inconsistência dinâmica, uma política ótima, quando avaliada numa data inicial de planejamento, não continua sendo ótima numa data posterior, embora nenhuma informaçáo nova tenha aparecido nesse meio-tempo. No caso dos IEDs, de acordo com os autores, o problema de inconsistência dinâmica decorre do fato de que, embora os países anfitrióes tenham um incentivo para prometer tratamento justo e equitativo para atrair investimentos estrangeiros, uma vez que o investimento seja estabelecido e os investidores tenham custos irreversíveis, há incentivos para o país anfitrião cobrar impostos mais elevados, restringir a repatriação de lucros, obrigar a contratação de mão de obra local, adquirir conteúdo nacional e até mesmo expropriar os ativos de investidores estrangeiros. ${ }^{4} \mathrm{Ou}$ seja, quando os investimentos já realizados envolvem custos irrecuperáveis, os anfitrióes podem extrair da empresa pelo menos até o valor desses custos sem que essa empresa tenha incentivos para encerrar suas atividades.

Como destaca Guasch (2004), um cenário típico de inconsistência dinâmica pode ocorrer nas concessóes para abastecimento de água, pois, buscando assegurar apoio popular durante uma campanha de reeleição, o governo pode impor à empresa concessionária cortes de tarifas ou não honrar os aumentos de tarifas acordados. Segundo o autor, outro cenário comum é um novo governo eleito que decida não honrar os aumentos tarifários acordados, por uma administração anterior, em um contrato de concessão, ou perseguir prioridades diferentes das da administração anterior, exigindo um novo plano de tarifas e investimentos da concessionária. Caso a empresa entenda as consequências do problema de inconsistência dinâmica antes de investir, pode optar por não investir no país estrangeiro

4. Nas décadas de 1960 e 1970, a expropriação direta era o risco mais significativo para o investimento estrangeiro. Atualmente, os meios pelos quais os países anfitriões discriminam ou expropriam o investimento estrangeiro são mais sutis (Büthe e Milner, 2008). 
ou pode manter o investimento exigindo um prêmio adicional (refletido em tarifas mais altas, por exemplo) para compensar o risco regulatório. Concomitantemente, para resolver possíveis disputas judiciais, o direito internacional não oferece um meio para que um país anfitrião faça compromissos confiáveis com um investidor de outro país. Portanto, fazer parte de um TBI e estar sujeito aos seus mecanismos de resoluçáo de disputas em caso de expropriação potencialmente protege o investidor contra um comportamento oportunista do país hospedeiro, evitando o problema de inconsistência dinâmica, que pode reduzir a rentabilidade esperada do investimento.

Kerner (2009) constrói as justificativas teóricas a respeito dos impactos positivos dos TBIs sobre o IED baseado no trabalho de Fearon (1997), em que são desenvolvidos argumentos teóricos sobre como os custos ex ante e expost associados ao não cumprimento de acordos firmados entre países podem tornar os compromissos críveis em razão de mecanismos do tipo hands-tying ou cost-sinking. Um mecanismo do tipo hands-tying atua gerando um custo em que um participante do acordo incorrerá expost se ele não cumprir o compromisso. $\mathrm{O}$ mecanismo cost-sinking atribui um custo irrecuperável ex ante a uma açáo, com o objetivo de separar participantes do acordo sinceros e náo sinceros.

Conforme destaca Kerner (2009), o TBI pode funcionar como um mecanismo hands-tying se e somente se os custos ex post de expropriação são suficientemente elevados para que os países participantes evitem fazê-lo. Em contrapartida, a assinatura do TBI pode gerar custos irrecuperáveis ex ante capazes de enviar um sinal a outros investidores não participantes do TBI. Isso pode ocorrer porque o TBI é capaz de limitar a regulação estatal e a aplicação de leis dos países receptores do investimento que poderiam ser interpretadas como expropriação. De outra forma, o risco de litígios baseado no tratamento preferencial previsto no TBI também contribui para a composição desse custo.

Com base nesses argumentos, o TBI pode impactar diretamente o IED entre os países signatários por meio do mecanismo hands-tying. Efeitos indiretos no IED ocorreriam em razáo dos custos irrecuperáveis induzidos pela assinatura de um TBI que pode ao menos gerar a expectativa de não haver expropriaçáo dos investimentos realizados por empresas de outros países que não fazem parte do acordo de investimento. Nessa direçáo, Neumayer e Spess (2005) argumentam que a assinatura de TBIs envia um sinal para potenciais investidores de que o país em desenvolvimento é geralmente sério sobre a proteção do investimento estrangeiro. É difícil afirmar, porém, o quão importante é o efeito de sinalização, que beneficia os investidores de todos os países, em comparação com o efeito de compromisso, que apenas se relaciona com investidores de países parceiros do TBI.

Para Tobin e Rose-Ackerman (2011), esse sinal se torna claro e o compromisso mais crível à medida que o número de TBIs com países desenvolvidos aumenta. Isso ocorre porque, gradativamente, mais fontes de IED são cobertas pelos mecanismos de enforcement incluídos no TBI. Acordos com outros países em desenvolvimento não enviariam esse sinal, principalmente se eles envolvem países que não são fontes prováveis de IED. Para os autores, é possível ainda que o benefício marginal de ingressar num TBI seja maior em países em desenvolvimento com melhor qualidade institucional. Os TBIs elevariam pouco o IDE nos ambientes mais arriscados e podem apresentar um efeito positivo mais perceptível para os países com níveis moderados de risco político.

Elkins, Guzman e Simmons (2006) destacam que a consolidação da reputação do país participante do TBI passa por acatar as decisóes dos tribunais internacionais definidos no tratado. Os autores ressaltam que, havendo alguma disputa judicial com um investidor no âmbito do TBI, o país anfitriáo não pode impedir o processo judicial de avançar, nem controlar a decisão final do 
tribunal internacional de arbitragem. $\mathrm{O}$ tribunal internacional pode exigir o pagamento por uma expropriação caso o país anfitrião esteja violando suas obrigaçóes acordadas no tratado. Recusar-se a cumprir a determinação do tribunal internacional poderia gerar danos profundos à reputação do país que recebeu o investimento, que certamente sofreria as consequências negativas de ser um parceiro econômico não confiável.

De acordo com Tobin e Rose-Ackerman (2011), dois países com fundamentos econômicos semelhantes atrairiam níveis variados de IED, dependendo do número de TBIs que eles têm em vigor, e o impacto marginal dos TBIs seria maior para países com fundamentos econômicos mais fortes. No entanto, um país com muitos TBIs, mas com baixa renda, crescimento lento e economia fechada, provavelmente não atrairá muito IDE, e os TBIs pouco podem fazer para melhorar essa situação, já que, embora afetem o risco de investimento, eles teriam pouco ou nenhum impacto sobre os fundamentos da economia. Segundo os autores, os TBIs seriam complementares aos aspectos locais tradicionalmente utilizados como determinantes dos IEDs, tais como tamanho do mercado e dotação de fatores. Tobin e Rose-Ackerman (2011) sugerem, por exemplo, que o efeito positivo que as dotaçóes geram no IED pode ser potencializado quando o país ratifica mais TBIs. Combinados com acordos de livre comércio, os TBIs podem também elevar os IEDs.

\subsection{Críticas aos TBls}

Não há consenso teórico sobre o papel desempenhado pelos TBIs na determinação dos IEDs. Para Yackee (2009), os TBIs têm pouca relevância na explicação da decisão de investimento de uma empresa multinacional por três motivos. Em primeiro lugar, os possíveis investidores não conhecem a existência dos TBIs no momento de decidir em que país investir - nessa mesma direção, Poulsen (2010) destaca que investidores procuram informaçóes sobre os TBIs com maior frequência quando surge alguma disputa, e não quando estão planejando seus investimentos. Em segundo lugar, Yackee (2009) acredita não haver razóes para esperar que os TBIs sejam mais eficazes do que a legislaçáo local na resoluçáo do problema de compromissos críveis nos contratos de investimento. Investimentos envolvendo elevados custos irrecuperáveis, como as concessóes de infraestrutura, são sempre cobertos por contratos detalhados, tornando os TBIs desnecessários. Em último lugar, de acordo com Guasch (2004), o prêmio de risco regulatório em projetos de infraestrutura (abastecimento de água, por exemplo) causado por contratos sem comprometimento crível é baixo, girando em torno de $2 \%$ a $6 \%$ do custo do capital. Não seria necessário, portanto, realizar um TBI para minimizar um possível risco regulatório que adicionaria pouco custo ao investimento.

Os TBIs também podem ser vistos por uma perspectiva mais pessimista, indicando possíveis efeitos negativos sobre o IED. De acordo com Tobin e Rose-Ackerman (2011), pode haver circunstâncias em que o TBI estimula apenas o IED do país de origem do investimento para países com os quais ele tem tal acordo. Ao mesmo tempo, o IED de outros países ou mesmo o investimento de empresas domésticas podem cair em razão do tratamento mais favorável concedido aos investimentos de uma fonte particular.

Um aspecto bastante crítico no TBI é o rigor de alguns mecanismos de solução de disputas entre investidor e Estado (investor-state dispute settlement - ISDS). Contribuiu para essa visáo crítica dos TBIs o aumento no número de casos em que as ISDS foram acionadas: de 326, em 2008, para 942 casos conhecidos, no final de 2018, envolvendo países desenvolvidos e em desenvolvimento como 
acusados. Desse total, 61\% das disputas foram favoráveis ao investidor e 39\% ao Estado anfitrião. ${ }^{5}$ Para Poulsen e Aisbett (2013), os países em desenvolvimento percebem os custos de participar dos TBIs quando começam a ser questionados por meio das ISDS e ao se verem obrigados a pagar vultosas indenizaçóes às empresas que investiram no país em razão do TBI. Como é destacado em documento de UNCTAD (2015), há receio de que o atual mecanismo de solução de controvérsias exponha os Estados receptores de investimentos externos a riscos jurídicos e financeiros adicionais, frequentemente imprevisíveis no momento da entrada no acordo, sem trazer necessariamente quaisquer benefícios em termos de fluxos adicionais de IED. Em alguns casos, são concedidos mais aos investidores estrangeiros direitos, em relação à solução de controvérsias, que aos investidores domésticos. Tais desequilíbrios entre Estado e investidor se manifestam ainda na concepção dos TBIs. Testes empíricos realizados por Allee e Peinhardt (2014) revelam que tratados de investimento contêm ISDS mais rígidas quando o parceiro exportador de capital do tratado tem considerável poder de barganha e suas empresas domésticas preferem tais acordos.

Há estudos indicando que as comissóes de julgamento podem favorecer mais o investidor que o Estado. Esse viés, segundo Nunnenkamp (2017), tende a penalizar mais os países em desenvolvimento que os de renda alta. Segundo o autor, uma inspeção mais rigorosa nos dados sobre resultados dos comitês arbitrais sugere que isso se deve em grande parte aos presidentes de tribunais que são mais tendenciosos em favor dos investidores que dos países em desenvolvimento. Representantes dos próprios Estados nos tribunais parecem ter menos influência sobre os resultados da ISDS. Segundo Donaubauer, Neumayer e Nunnenkamp (2018), se o presidente do comitê de arbitragem já foi representante do investidor em outras ocasiôes, é mais provável que sua decisão, que normalmente tende a ser a de desempate, seja a favor do investidor.

Buscando evitar disputas com os investidores, os países em desenvolvimento tentam manter a conformidade de suas políticas com o estabelecido no TBI. Como consequência, conforme Neumayer e Spess (2005) e Elkins, Guzman e Simmons (2006) destacam, é enorme a extensão da interferência na soberania reguladora doméstica a que os países em desenvolvimento sucumbem ao assinar TBIs e se submeterem às cláusulas da ISDS. Ao ratificarem um TBI, os países em desenvolvimento podem estar "trocando a soberania pela credibilidade". Dependendo da forma como esses mecanismos são definidos no tratado, virtualmente qualquer regulamentação de política pública pode ser potencialmente contestada por meio do mecanismo de solução de controvérsias do tratado, desde que afete os investidores estrangeiros, mesmo que tal regulamentação seja de interesse público. Isso acontece quando os investidores consideram que a política pública implementada pelo Estado anfitriâo resultou numa expropriaçáo indireta, que seria uma perda de rentabilidade do investimento em razão de alguma ação praticada pelo Estado. Em 2010, por exemplo, a empresa Philip Morris entendeu que a política antitabagismo do Uruguai prejudicaria suas vendas. Em razão disso, o investidor registrou uma reclamação contra o país no ICSID $^{6}$ sob os termos do TBI Suíça-Uruguai solicitando uma indenização para compensar suas possíveis perdas. Nesse caso, o ICSID decidiu em favor do Estado, obrigando inclusive a empresa a arcar com os custos processuais que o Uruguai teve no decorrer do processo, mas certamente o processo todo foi uma ameaça a uma importante política nacional.

5. Disponível em: $<$ https://bit.ly/3d2Xs0k>.

6. Caso ICSID no ARB/10/7. 
A esse conjunto de críticas, Hallward-Driemeier (2003) adiciona que, à medida que o potencial para o recurso legal sob os TBIs for mais amplamente conhecido pelas empresas, a importância dos TBIs na seleção de um local para realizar o investimento pode se tornar mais importante e levar a problemas de risco moral e seleção adversa. Se os investidores acreditam que há uma chance de litígio bem-sucedido contra o governo anfitriáo e que eles são protegidos contra riscos substanciais, as empresas podem se esforçar menos para cumprir o estabelecido no acordo. Em contrapartida, as empresas com maior probabilidade de investir no país receptor podem ser aquelas mais interessadas em buscar todos os recursos legais para obter algum benefício. Esse comportamento do investidor, além de reduzir a eficiência do investimento externo, pode elevar os custos dos países receptores para resolver os litígios em tribunais internacionais.

A procura dos países em desenvolvimento por fazer parte de acordos de investimento pode significar um processo de concorrência entre países por mais IEDs (Elkins, Guzman e Simmons, 2006; Guzman, 2009). O incentivo individual para elevar as receitas de investimento por meio do TBI e se beneficiar dos efeitos gerados pelo IED leva os países a ratificarem TBIs para disputar com outros que possuem tratados de investimento já em andamento. A estratégia concorrencial entre países por investimentos não se limita à busca por participar de TBIs. A esse respeito, Neumayer, Nunnenkamp e Roy (2016) apontam que existe também "contágio" dos termos dos acordos, em particular nas cláusulas de resolução de controvérsias. Acordos de países em desenvolvimento com países desenvolvidos que contenham cláusulas rígidas em favor do investidor tendem a ser replicados em acordos de outros países em desenvolvimento. Com relação à predisposição para aceitar a perda de soberania, Allee e Peinhardt (2010) argumentam que, mesmo os governos anfitrióes do investimento não concordando com as condiçôes rígidas para a resoluçáo de controvérsias em tribunais internacionais, principalmente quando os custos de soberania são altos, eles são mais propensos a concordar com tais cláusulas quando são mais dependentes de suas relaçóes com outros países. Ao fim dessas interaçóes, os países em desenvolvimento, principalmente aqueles mais dependentes de IED, acabam por escolher assinar TBIs contendo cláusulas mais rígidas beneficiando o investidor externo diante de uma possível disputa com o estado anfitriáo. Nessa situação, esses países tendem a perder o excedente do investimento ou podem estar incorrendo em custos ao desistir de instrumentos domésticos de promoçáo de desenvolvimento econômico e social, tais como os requerimentos de performance, a contratação de mão de obra local, a tributação etc., para atrair investidores por meio dos TBIs.

No quadro 1, elaborado pela Conferência das Naçóes Unidas sobre Comércio e Desenvolvimento (United Nations Conference on Trade and Development - UNCTAD), está a síntese das vantagens e desvantagens de fazer parte de um TBI. As desvantagens elencadas certamente colocam em dúvida se os custos do TBI são compensados pelos seus benefícios. Como será visto mais adiante, existe em curso um grande esforço dos países e de organismos como a UNCTAD de definir um novo modelo de TBI que ao menos diminua a exposição dos países em desenvolvimento aos riscos associados à ratificação do tratado e que também permita aos países a liberdade de colocar em prática suas políticas de interesse público, sem o receio do acionamento num comitê de arbitragem por, supostamente, ter afetado negativamente o fluxo de caixa de uma empresa. 
QUADRO 1

Vantagens e desvantagens do TBI

\begin{tabular}{|c|c|}
\hline Vantagens & Desvantagens \\
\hline Contribui para um ambiente favorável ao investimento. & Não garante a entrada de investimentos adicionais. \\
\hline $\begin{array}{l}\text { Contribui para fomentar e expandir a cooperação econômica e política } \\
\text { entre as partes contratantes. }\end{array}$ & $\begin{array}{l}\text { Pode afetar negativamente o direito soberano dos países anfitriões de } \\
\text { regular o interesse público. }\end{array}$ \\
\hline $\begin{array}{l}\text { Contribui para a estabilidade e previsibilidade do quadro político, promove } \\
\text { a boa governança e o estado de direito. }\end{array}$ & $\begin{array}{l}\text { Expõe os Estados anfitriões aos tribunais internacionais de resolução de } \\
\text { controvérsias e aos riscos financeiros associados. }\end{array}$ \\
\hline $\begin{array}{l}\text { Fornece direitos de proteção que sejam independentes da legislação } \\
\text { interna dos países anfitriões (superioridade do direito internacional sobre } \\
\text { a lei nacional). }\end{array}$ & Privilegia os investidores estrangeiros sobre os investidores domésticos. \\
\hline $\begin{array}{l}\text { Em comparação com o direito internacional consuetudinário, melhora a } \\
\text { segurança jurídica, uma vez que os direitos de proteção são especificados } \\
\text { no tratado. }\end{array}$ & Fornece apenas os direitos dos investidores, não estabelecendo obrigações. \\
\hline Reduz os riscos políticos de investir no exterior. & $\begin{array}{l}\text { Reflete um resultado negociado que é influenciado pelo poder de barganha } \\
\text { das partes negociadoras. }\end{array}$ \\
\hline Pode facilitar a concessão de garantias de investimento pelo país de origem. & $\begin{array}{l}0 \text { acordo de investimento pode resultar em obrigações sobrepostas e } \\
\text { inconsistentes das partes contratantes. }\end{array}$ \\
\hline Ajuda a evitar a politização de disputas de investimento. & É difícil alterar em caso de mudança de circunstâncias econômicas. \\
\hline
\end{tabular}

Fonte: UNCTAD (2015)

\section{TENDÊNCIAS PARA OS TBIS}

A série histórica sobre o número de TBIs assinados revela uma tendência de redução de novos acordos a partir de 2009. Em parte, essa redução é resultado do encerramento de alguns acordos de investimento, envolvendo, por exemplo, África do Sul, Equador, Índia e Indonésia ${ }^{7}$ (Cervantes-Knox e Thomas, 2017). Com efeito, o ano de 2017 foi concluído com o menor número de novos acordos internacionais de investimento desde 1983 e, pela primeira vez, o número de tratados com prazo encerrado superou o número de novas conclusôes de acordos de investimento, sinalizando um período de reflexão e revisão de políticas de investimento internacional. ${ }^{8}$

No centro das decisôes de encerramento de TBIs estão os mecanismos de ISDS, que, como já foi discutido, têm resultado em um número crescente de reclamaçóes junto ao ICSID. Segundo documento de acompanhamento das políticas de investimento da UNCTAD, a maioria dos novos acordos firmados em 2018 já traz mudanças importantes nesse ponto. ${ }^{9}$ As mudanças mais frequentes nos acordos são cláusulas estabelecendo que devem ser esgotadas as possibilidades locais de resolução das disputas antes de o processo de arbitragem num tribunal internacional começar e que deve haver aumento do controle dos processos por parte do governo e de medidas que buscam julgamentos mais transparentes e imparciais. Em alguns novos tratados, optou-se simplesmente por não incluir a possibilidade de submeter uma disputa entre investidor e Estado a um tribunal de arbitragem internacional. Bernasconi-Osterwalder (2015) ressalta ainda que reformulaçóes nas ISDS envolvem também a criação de um mecanismo de apelação, em que as decisôes arbitrais poderiam ser revistas e totalmente modificadas. Além disso, em alguns acordos, optou-se por manter apenas o mecanismo de disputa do tipo Estado-Estado.

7. Disponível em: $<$ https://bit.ly/3d2Xs0k>.

8. Disponível em: <https://bit.ly/3xl1qu5>.

9. Há também iniciativas de modernização dos tratados antigos, com o propósito de contemplar neles essas novas tendências na normatização das disputas entre investidor e Estado. A China, por exemplo, modernizou recentemente 32 dos seus 144 TBls (Huang, 2018). 
Outras mudanças importantes também visam minimizar a exposição do país hospedeiro à arbitragem internacional, definindo com maior clareza o que seria expropriação indireta, limitando os tipos de ativos que constituem o IED e excluindo do escopo do tratado as políticas públicas adotadas por governos locais. Também fazem parte dos novos modelos cláusulas com orientação pró-desenvolvimento sustentável, estabelecendo que as partes não podem abrir mão de políticas relacionadas à saúde, à segurança e à preservaçáo do meio ambiente para atrair investimento externo (UNCTAD, 2019).

Na questáo dos acordos de investimento, o Brasil caminha na direçáo de TBIs com instrumentos de resoluçáo de disputas mais brandos. Apresentado em 2015, o modelo de acordo bilateral de investimento brasileiro, chamado de Acordo de Cooperação e Facilitação de Investimentos (ACFI), tem formato inovador e, diferentemente dos TBIs tradicionais, que são voltados para a proteção do investidor, se concentra principalmente na facilitação de cooperação e investimento entre as partes (Brauch, 2015). Ademais, o ACFI propóe o estabelecimento de pontos focais, ou ombudsmen, em cada Estado-parte, além da criação de um comitê conjunto intergovernamental. Essas instâncias podem ser consideradas o núcleo institucional do acordo, pois contribuem para a concretização dos compromissos firmados e para o fortalecimento do diálogo entre as partes em matéria de investimento. ${ }^{10}$ Desde 2015, o Brasil já celebrou acordos de investimento nos moldes dos ACFIs com países da América do Sul e da África e com o México.

É importante destacar que o Brasil experimentou um elevado crescimento no ingresso de IED nos últimos anos. De acordo com Jadhav (2012), a maior parte do IDE no período recente nas economias do BRICS ${ }^{11}$ foi motivada pelo propósito de busca do mercado. Ademais, o país aparenta ser um destino confiável para o investimento externo, uma vez que investidores estrangeiros são bem protegidos pelo sistema jurídico nacional. A exemplo disso, a Lei no 8.987/1995 permite que sejam previstos mecanismos de solução de controvérsias nos contratos de concessão de serviços públicos caracterizados por custos elevados irrecuperáveis, propiciando alguma proteção jurídica previsível ao investidor externo. Dessa forma, mesmo sem ratificar seus TBIs na década de 1990, o Brasil conseguiu atrair vultosos montantes de IED para o setor de distribuição de energia elétrica, conforme apontam Andrade, Silva Filho e Leite (2017). Segundo os autores, as mudanças regulatórias para o IED no Brasil promovidas entre 2005 e 2006 - que, entre outros aspectos, reduziu o risco cambial para empresas estrangeiras no país - podem ter contribuído para o país ser um dos principais destinos de investimento no mundo. Isso não significa, porém, que o ingresso de IED no Brasil não foi impactado pela inexistência de acordos de investimento em vigência no país durante o período de elevada expansão mundial no número de TBIs. Certamente, um estudo empírico ajudaria a esclarecer em que medida o país receberia ainda mais investimentos externos do que recebeu caso tivesse ratificado seus acordos.

\section{CONCLUSÕES}

Os TBIs se tornaram um dos principais mecanismos para a atração de IED nos países em desenvolvimento nas últimas décadas. Segundo a teoria, fazer parte do TBI e cumprir seus termos daria um sinal claro aos investidores internacionais de que seria seguro investir no país. Todavia, esse tipo de acordo

10. Disponível em: <https://bit.ly/3y5CLZJ>.

11. Brasil, Rússia, Índia, China e África do Sul. 
está sujeito a várias críticas. Uma delas diz respeito à possível perda de soberania para implementar políticas públicas de interesse da sociedade em troca da participação num acordo de investimento. A crítica mais recorrente deriva dos mecanismos de ISDS. Principalmente quando no acordo não está claro o significado de expropriação, há margem para os investidores acionarem os Estados receptores em tribunais internacionais, gerando custos jurídicos não previstos e também uma possível perda de credibilidade. A falta de transparência nas decisóes dos tribunais internacionais, a maioria delas sendo a favor do investidor, também é um aspecto negativo para os TBIs.

Além disso, o uso de TBIs como instrumento de concorrência por IED entre países pode levar a uma situação socialmente indesejável, na medida em que são inseridos nos acordos termos favorecendo demasiadamente o investidor, em detrimento da soberania para regulamentar a atividade econômica e implementar políticas de interesse social. Alguns autores (Guzman, 2009) chegam à conclusão de que a concorrência por IED faz os países se defrontarem com um problema do tipo dilema dos prisioneiros: os países em desenvolvimento poderiam estar em vantagem se não adotassem o TBI como estratégia, mas acabam por assinar esses acordos, com receio de perder oportunidades de IED.

Em razão principalmente dos problemas resultantes dos mecanismos de solução de controvérsias, está em curso uma reforma no formato dos TBIs, seja para os novos acordos, seja para os antigos que estão sendo modernizados. Nas linhas gerais desse novo formato de TBI está a melhor definição do que deve ser considerado como expropriação indireta e também de termos que garantam o direito de regular, gerando um bom ambiente de investimento sem perder o direito de criar regulaçóes que permitam perseguir objetivos de desenvolvimento sustentável e outros objetivos socioeconômicos.

Os resultados que esses novos acordos estáo gerando em termos de ingressos de IED e desenvolvimento econômico certamente serão objeto de análise em estudos empíricos futuros, à medida que novos dados sobre os IEDs vão sendo publicados. Em face da grande tendência nos novos TBIs de náo haver sacrifício de políticas de interesse público e ao mesmo tempo haver garantias de um bom ambiente de investimento para empresas estrangeiras, espera-se que a competição entre países por meio dos TBIs resulte numa distribuição de IED cujas recompensas sejam mais bem aceitas pela sociedade.

\section{REFERÊNCIAS}

ALLEE, T.; PEINHARDT, C. Delegating differences: bilateral investment treaties and bargaining over dispute resolution provisions. International Studies Quarterly, v. 54, n. 1, p. 1-26, 2010.

Evaluating three explanations for the design of bilateral investment treaties. World Politics, v. 66, n. 1, p. 47-87, 2014.

ANDRADE, I. O.; SILVA FILHO, E. B.; LEITE, A. W. Análise da regulação dos investimentos estrangeiros diretos no Brasil. In: MESSA, A.; OLIVEIRA, I. T. M. (Org.). A política comercial brasileira em análise. Brasília: Ipea, 2017.

BÉNASSY-QUÉRÉ, A.; COUPET, M.; MAYER, T. Institutional determinants of foreign direct investment. World Economy, v. 30, n. 5, p. 764-782, 2007.

BERNASCONI-OSTERWALDER, N. Rethinking investment-related dispute settlement. Investment Treaty News, v. 6, n. 2, 2015.

BLONIGEN, B. A. A review of the empirical literature on FDI determinants. Atlantic Economic Journal, v. 33, n. 4, p. 383-403, 2005. 
BRAUCH, M. D. The Brazil-Mozambique and Brazil-Angola Cooperation and Investment Facilitation Agreements (CIFAs): a descriptive overview. Investment Treaty News, v. 6, n. 2, 2015.

BUCHANAN, B. G.; LE, Q. V.; RISHI, M. Foreign direct investment and institutional quality: some empirical evidence. International Review of Financial Analysis, v. 21, p. 81-89, 2012.

BÜTHE, T.; MILNER, H. V. The politics of foreign direct investment into developing countries: increasing FDI through international trade agreements? American Journal of Political Science, v. 52, n. 4, p. 741-762, 2008.

CERVANTES-KNOX, K.; THOMAS, E. Ecuador terminates 12 BITs - a growing trend of reconsideration of traditional investment treaties? International arbitration alert. [s.l.]: DLA Piper, 15 May 2017.

COLEN, L.; PERSYN, D.; GUARISO, A. Bilateral investment treaties and FDI: does the sector matter? World Development, v. 83, p. 193-206, 2016.

COZENDEY, C. M. B.; CAVALCANTE, P. M. Novas perspectivas para acordos internacionais de investimentos o Acordo de Cooperação e Facilitação de Investimentos (ACFI). Cadernos de Política Exterior, Brasília, v. 1, n. 2, p. 87-109, 2015.

DONAUBAUER, J.; NEUMAYER, E.; NUNNENKAMP, P. Winning or losing in investor-to-state dispute resolution: the role of arbitrator bias and experience. Review of International Economics, v. 26, n. 4, p. 892-916, 2018.

EGGER, P.; PFAFFERMAYR, M. The impact of bilateral investment treaties on foreign direct investment. Journal of Comparative Economics, v. 32, n. 4, p. 788-804, 2004.

ELKINS, Z.; GUZMAN, A. T.; SIMMONS, B. A. Competing for capital: the diffusion of bilateral investment treaties, 1960-2000. International Organization, v. 60, n. 4, p. 811-846, 2006.

FEARON, J. D. Signaling foreign policy interests: tying hands versus sinking costs. Journal of Conflict Resolution, v. 41, n. 1, p. 68-90, 1997.

GUASCH, J. L. Granting and renegotiating infrastructure concessions: doing it right. Washington: The World Bank, 2004. (WBI Development Studies).

GUZMAN, A. T. Explaining the popularity of bilateral investment treaties. In: SAUVANT, K. P.; SACHS, L. E. The effect of treaties in foreign direct investment: bilateral investment treaties, double taxation treaties, and investment flows. Oxford: Oxford University Press, 2009. p. 73-98.

HALLWARD-DRIEMEIER, M. Do bilateral investment treaties attract foreign direct investment? Only a bit... and they could bite. Washington: World Bank Group, 2003. (Policy Research Working Paper, n. WPS 3121).

HUANG, J. J. Procedural models to upgrade BITs: China's experience. Leiden Journal of International Law, v. 31, n. 1, p. 93-115, 2018.

JADHAV, P. Determinants of foreign direct investment in BRICS economies: analysis of economic, institutional and political factor. Procedia-Social and Behavioral Sciences, v. 37, p. 5-14, 2012.

JOHNSON, L.; SACHS, L. International investment agreements, 2011-2012: a review of trends and new approaches. In: BJORKLUND, A. (Ed.). Yearbook on international investment law and policy. Oxford: Oxford University Press, 2014. p. 219-271.

KERNER, A. Why should I believe you? The costs and consequences of bilateral investment treaties. International Studies Quarterly, v. 53, n. 1, p. 73-102, 2009.

KOHLER, W.; STÄHLER, F. The economics of investor protection: ISDS versus national treatment. Journal of International Economics, v. 121, n. 2, 2016. 
MOROSINI, F. C.; XAVIER JUNIOR, E. C. X. Regulação do investimento estrangeiro direto no Brasil: da resistência aos tratados bilaterais de investimento à emergência de um novo modelo regulatório. Revista de Direito Internacional, v. 12, n. 2, 2015.

MUCHLINSKI, P. The framework of investment protection: the content of BITs. In: SAUVANT, K. P.; SACHS, L. E. The effect of treaties in foreign direct investment: bilateral investment treaties, double taxation treaties, and investment flows. Oxford: Oxford University Press, 2009. p. 37-71.

NEUMAYER, E.; NUNNENKAMP, P.; ROY, M. Are stricter investment rules contagious? Host country competition for foreign direct investment through international agreements. Review of World Economics, v. 152, n. 1, p. 177-213, 2016.

NEUMAYER, E.; SPESS, L. Do bilateral investment treaties increase foreign direct investment to developing countries? World Development, v. 33, n. 10, p. 1567-1585, 2005.

NUNNENKAMP, P. Biased arbitrators and tribunal decisions against developing countries: stylized facts on investor-state dispute settlement. Journal of International Development, v. 29, n. 6, p. 851-854, 2017.

POULSEN, L. N. S. The importance of BITs for foreign direct investment and political risk insurance: revisiting the evidence. In: SAUVANT, K. P. Yearbook on international investment law and policy 2009-2010. Oxford: Oxford University Press, 2010. p. 539-574.

POULSEN, L. N. S.; AISBETT, E. When the claim hits: bilateral investment treaties and bounded rational learning. World Politics, v. 65, n. 2, p. 273-313, 2013.

ROSE-ACKERMAN, S.; TOBIN, J. Foreign direct investment and the business environment in developing countries: the impact of bilateral investment treaties. Yale Law and Economics Research Paper, n. 293, 2005.

TOBIN, J. L.; ROSE-ACKERMAN, S. When BITs have some bite: the political-economic environment for bilateral investment treaties. Review of International Organizations, v. 6, n. 1, p. 1-32, 2011.

UNCTAD - UNITED NATIONS CONFERENCE ON TRADE AND DEVELOPMENT. International investment instruments: a compendium. New York; Geneva: United Nations, 1996. v. 1.

Bilateral investment treaties: 1959-1999. New York; Geneva: United Nations, 2000.

World investment report 2015: reforming international investment governance. New York; Geneva: United Nations, 2015.

UNCTAD's reform package for the international investment regime. New York; Geneva: United Nations, 2018a.

Recent developments in the international investment regime. IIA Issues Notes, n. 1, p. 1-11, May 2018b.

YACKEE, J. W. Do BITs really work? Revisiting the empirical link between investment treaties and foreign direct investment. In: SAUVANT, K. P.; SACHS, L. E. The effect of treaties in foreign direct investment: bilateral investment treaties, double taxation treaties, and investment flows. Oxford: Oxford University Press, 2009. p. 379-394. 


\title{
O MODELO DE ACORDO DE COOPERAÇÃO E FACILITAÇÃO DE INVESTIMENTOS (ACFI) DO BRASIL E O REGIME INTERNACIONAL DE INVESTIMENTOS: OS CASOS DE ANGOLA E MOÇAMBIQUE
}

Ana Garcia'

Gabriel Torres ${ }^{2}$

\begin{abstract}
SINOPSE
Os tratados bilaterais de investimento (TBIs) surgiram no período pós-Segunda Guerra Mundial, mas proliferaram nos anos 1990, alcançando quase todos os países do mundo. Questionamentos quanto à efetividade dos TBls para aumentar o fluxo de investimentos e seu efeito sobre políticas públicas de interesse social e ambiental levaram muitos países a reformular seus parâmetros. Nesse contexto, surge o modelo brasileiro de Acordo de Cooperação e Facilitação de Investimentos (ACFI), assinado inicialmente junto a países africanos. Neste trabalho, apresentamos o contexto de criação e o conteúdo dos ACFIs por meio de uma análise dos acordos com Angola e Moçambique, comparando-os com os demais TBIs destes países. Argumentamos que o início do ACFI com os países africanos, em 2015, refletiu interesses estratégicos do governo brasileiro naquele momento, bem como o histórico da atuação de empresas multinacionais brasileiras, que enfrentaram disputas e conflitos. $\mathrm{OACFI}$ traz aspectos inovadores que atenuam os elementos críticos dos TBIs tradicionais, porém sua implementação precisará ser acompanhada para que tenha efeitos positivos no sentido de investimentos social e ambientalmente responsáveis, tal como o modelo brasileiro se propõe.
\end{abstract}

Palavras-chave: ACFl; tratados bilaterais de investimentos; Angola; Moçambique.

\begin{abstract}
After the proliferation of bilateral investment treaties (BITs) in the post-World War II period, especially during the 1990s, concerns about their effectiveness in increasing investment flows, or their impact on social and environmental policy space, led many countries to review their parameters. In this context, Brazil enacted a new model of Cooperation and Investment Facilitation Agreements (CIFAs), initially signed with African countries. In this paper, we present the context of the creation of CIFAs and their contents, through an analysis of the agreements with Angola and Mozambique in comparison to other BITs signed by those countries. We argue that the CIFAs were initially signed with African countries, in 2015, due to strategic interests of the Brazilian government at that moment, as well as due to the history of Brazilian multinationals' presence, which faced disputes and conflicts. The CIFA model brings innovative aspects that attenuate criticized elements of traditional BITs, such as the Investor-State dispute settlement clause. However, its implementation will need to be closely monitored to ensure it has positive effects for social and environmentally responsible investments, as the Brazilian model intends to promote.
\end{abstract}

Keywords: CIFA; BIT, Angola; Mozambique; investment.

JEL: F21; F23; N4.

Artigo recebido em 2/3/2021 e aprovado em 11/3/2021.

DOl: http://dx.doi.org/10.38116/bepi29art7

1. Pesquisadora do Programa de Pesquisa para o Desenvolvimento Nacional (PNPD) na Diretoria de Estudos e Relações Econômicas e Políticas Internacionais (Dinte) do Ipea; professora adjunta do Instituto de Relações Internacionais da Pontifícia Universidade Católica do Rio de Janeiro (IRI/PUC-Rio) e do programa de pós-graduação em ciências sociais da Universidade Federal Rural do Rio de Janeiro (PPGCS/UFRRJ). E-mail: <anasaggioro@puc-rio.br>.

2. Mestre em análise e gestão de políticas internacionais pela PUC-Rio; assessor técnico júnior na GIZ. E-mail: <gabrielbt95@gmail.com>. 


\section{INTRODUÇÃO}

Um tratado bilateral de investimento (TBI) é um acordo entre dois países com a finalidade de promover e proteger o investimento realizado por empresas de cada país no território do outro. A grande maioria dos acordos internacionais de investimento (AII) sáo TBIs, mas também envolve os tratados de livre comércio e demais acordos que contêm cláusulas estruturantes sobre investimento. ${ }^{3}$ Atualmente, existem 2.896 TBIs e outros 416 AIIs assinados em todo mundo.

Esses acordos têm origem no século XIX, mas ganham força e relevância no período pós-Segunda Guerra Mundial, com o contexto geopolítico da Guerra Fria e de descolonização de países na África e Ásia. Com a abertura de mercados e o período da globalização nos anos 1990, os TBIs adquiriram alcance global, envolvendo quase todos os países do mundo (Vandelvede, 2009; UNCTAD, 2015). Esses tratados refletiram assimetrias econômicas entre os países, e suas regras expressam o poder de empresas multinacionais no capitalismo no século XX, resultando na limitação do escopo de atuação dos Estados nacionais sobre suas políticas públicas em temas de interesse abrangente, como questóes de direitos humanos, sociais e ambientais (Arroyo e Ghiotto, 2017; Hernandez, 2015). A cláusula mais sensível dos TBIs tradicionais permite ao investidor estrangeiro levar um Estado nacional a foros de arbitragem internacional, desviando dos foros domésticos em casos de conflitos e disputas em torno do investimento. Nos últimos anos, países africanos vêm sendo levados a foros internacionais de arbitragem com base em seus TBIs, resultando em custos altos para países tradicionalmente pobres (Müller e Olivet, 2019).

Tais aspectos críticos e questionamentos quanto à efetividade dos TBIs para aumentar o fluxo de investimentos levaram a que, recentemente, muitos países busquem reformular seus parâmetros. É precisamente nesse contexto de reforma que se enquadra o novo modelo brasileiro de Acordo de Cooperação e Facilitação de Investimento (ACFI). Nos anos 1990, os TBIs assinados pelo Brasil não foram ratificados, porém, com a crescente expansão internacional de empresas brasileiras, o país passou a buscar promover suas próprias empresas no exterior. Em 2015, os primeiros ACFIs foram assinados com países africanos, e, neste trabalho, apresentamos o contexto de criação e o conteúdo deles por meio de uma análise dos acordos com Angola e Moçambique. Argumentamos que o início do ACFI com os países africanos refletiu interesses estratégicos do governo brasileiro naquele momento, bem como o histórico da atuação de empresas multinacionais brasileiras, que enfrentaram disputas e conflitos. $\mathrm{O}$ acordo traz aspectos inovadores que atenuam os elementos críticos dos TBIs tradicionais, porém sua implementação precisará ser acompanhada para que tenha efeitos positivos no sentido de investimentos social e ambientalmente responsáveis, tal como o modelo brasileiro se propóe.

\section{O ACFI BRASILEIRO NO CONTEXTO DE REFORMA DO REGIME INTERNACIONAL DE INVESTIMENTOS}

O Brasil é o principal receptor de investimento estrangeiro e também o maior investidor externo da América Latina. Apesar disso, o país tem um número pequeno de acordos de proteção de investimentos, tendo assinado, no total, 27 TBIs e outros 19 acordos com provisão de investimentos. ${ }^{4}$ Entre os TBIs, catorze foram assinados entre 1994 e 1999, mas nunca foram aprovados pelo Legislativo brasileiro.

3. Disponível em: <https://investmentpolicy.unctad.org/international-investment-agreements>.

4. Disponível em: <https://investmentpolicy.unctad.org/international-investment-agreements/countries/27/brazil?type=tips >. 
Os outros treze compóem o novo modelo de Acordo de Cooperação e Facilitaçáo de Investimentos (ACFI), e começaram a ser assinados em 2015. Alguns deles já foram aprovados pelo Legislativo mas apenas dois, o ACFI com Angola ${ }^{5}$ e o com o México, ${ }^{6}$ já se encontram em vigor. O quadro 1 lista os ACFIs brasileiros.

QUADRO 1

ACFIs do Brasil

\begin{tabular}{|l|l|l|}
\hline \multicolumn{1}{|c|}{ País } & Assinado em & Em vigor desde \\
\hline Angola & 2015 & 2017 \\
\hline Moçambique & 2015 & - \\
\hline México & 2015 & 2018 \\
\hline Malaui & 2015 & - \\
\hline Colômbia & 2015 & \\
\hline Chile' & 2015 & - \\
\hline Protocolo de Cooperação e Facilitação de Investimentos - Mercosul & 2017 & \\
\hline Etiópia & 2018 & \\
\hline Suriname & 2018 & \\
\hline Guiana Francesa & 2018 & - \\
\hline Emirados Árabes Unidos & 2019 & - \\
\hline Marrocos & 2019 & - \\
\hline Equador & 2019 & - \\
\hline Índia & 2020 & - \\
\hline
\end{tabular}

Fonte: UNCTAD. Disponível em: <https://investmentpolicy.unctad.org>

Elaboração dos autores.

Nota: ${ }^{1} \mathrm{O}$ ACFI com o Chile foi assinado em 2015, porém, nos anos seguintes foi negociado um Acordo de Livre Comércio (comunicação de 21 de novembro de 2018), que supera o ACFI. Disponível em: <https://www.camara.leg.br/proposicoesWeb/fichadetramita cao?idProposicao $=2217142>$.

Nos anos 1990, os TBIs assinados pelo Brasil seguiam o modelo tradicional de TBI. Este modelo traz normativas legais, as quais destacamos: o tratamento nacional ao investidor estrangeiro; tratamento justo e equitativo; o princípio da nação mais favorecida; garantia de proteção à propriedade intelectual como parte do investimento; o compromisso de pagamento de compensaçáo imediata, justa e efetiva, em caso de expropriaçáo; limites ao controle de capital; garantia de estabilidade de cláusulas do tratado após ratificado; proibiçáo de requisitos de desempenho ao investidor por parte do Estado anfitrião; e duração de efeito residual, que estende a proteção ao investimento por anos após o término de um TBI, entre outras (Vandevelde, 2009; Arroyo e Ghiotto, 2017). O coração dos TBIs está na cláusula de solução de controvérsias, que permite ao investidor estrangeiro litigar um Estado em arbitragem internacional em casos de conflito, se considerar mudanças em legislaçóes nacionais ou políticas públicas "medidas equivalentes à expropriação", frustrando "legítimas expectativas de lucro" (Godinho e Cozendei, 2015).

Nesse sentido, o Legislativo brasileiro compreendeu que esses acordos dariam direitos ao investidor estrangeiro em detrimento do nacional. Morosini e Xavier Júnior (2015) trazem alguns trechos do relatório elaborado pela Comissão de Relaçôes Exteriores e de Defesa Nacional (CREDN) do Congresso Nacional sobre os tratados assinados pelo Executivo. Neste relatório, a CREDN afirma

5. Disponível em: <http://www.planalto.gov.br/ccivil_03/_ato2015-2018/2017/decreto/D9167.htm>.

6. Disponível em: <http://www.planalto.gov.br/ccivil_03/_ato2015-2018/2018/decreto/d9495.htm>. 
que "a forma de indenizaçáo definida no texto precisa ser confrontada com alguns dos preceitos constitucionais vigentes acerca da desapropriação de imóveis urbanos e rurais" (Parecer da Comissão de Relações Exteriores e Defesa Nacional apud Morosini e Xavier Júnior, 2015, p. 428), além de que tais tratados "estabeleciam o compromisso com a livre transferência de recursos, independentemente da disponibilidade de divisas pelo país, o que, obviamente, representava um tratamento diferenciado em relação ao dispensado aos nacionais" (Alves, 2014 apud Morosini e Xavier Júnior, 2015, p. 428). No que tange à solução de controvérsias, "as normas contrariam regra de direito internacional consuetudinário tradicionalmente adotada pelo Brasil, o princípio do esgotamento de recursos internos" (Parecer da Comissão de Relaçôes Exteriores e Defesa Nacional apud Morosini e Xavier Júnior, 2015, p. 428). Nesse sentido, investidores internacionais obtêm vantagens adicionais diante de investidores nacionais e de políticas públicas de interesse geral, implementadas pelo Estado anfitriáo.

Diante das críticas e crescente resistência, o projeto de ratificação dos TBIs foi retirado de tramitação no Congresso Nacional em 2002, no contexto de transição do governo Fernando Henrique Cardoso para o governo Lula da Silva (Morosini e Xavier Júnior, 2015). Cabe ressaltar que o ambiente internacional (regional e global) também influenciou essa decisão. No âmbito global, as negociaçóes sobre o Acordo Multilateral sobre Investimentos (Multilateral Agreement on Investimet - MAI), capitaneado pela Organização para a Cooperação e Desenvolvimento Econômico (OCDE), sofriam resistências e não foram à frente. $\mathrm{Na}$ região, o Brasil e outros países resistiam à implantação de uma Área de Livre Comércio das Américas (ALCA) com os Estados Unidos.

Morosini e Xavier Júnior (2015) consideram que a postura brasileira se provou prudente, uma vez que outros países da América do Sul, que vinham mantendo TBIs com vários países do mundo, terminaram sendo levados à arbitragem internacional. É o caso da Argentina que, com a crise econômica de 2001, sofreu diversos procedimentos arbitrais instaurados no âmbito do Centro Internacional para a Arbitragem de Disputas sobre Investimentos (CIADI). ${ }^{7}$ Neste sentido, os autores ponderam que

\begin{abstract}
ainda que se concorde com a doutrina especializada no sentido de que os tratados bilaterais de investimento servem para assegurar um certo grau de uniformidade com relação aos standards que governam as relaçôes de investimento (...) é bastante evidente que o interesse preponderante desses instrumentos é a proteção do investidor (...). Portanto, o país de destino do investimento que se compromete com esses tratados deve antes se certificar de que a reduçáo do policy space é compensada pelas oportunidades de investimento geradas (Morosini e Xavier Júnior, 2015, p. 426).
\end{abstract}

Apesar de não ter ratificado tais TBIs, é importante notar que, com exceção da cláusula investidor-Estado, as demais diretrizes de proteção ao investidor foram incorporadas à legislação brasileira por meio de reformas econômicas domésticas ao longo dos anos 1990. Em 1995, o Congresso brasileiro aprovou uma emenda constitucional que eliminava qualquer tipo de discriminação a investidores estrangeiros, o que equivaleria às cláusulas de tratamento nacional e tratamento justo e equitativo (Arroyo e Ghiotto, 2017). Por sua vez, o Conselho Monetário Nacional e o Banco Central

7. Segundo Arroyo e Ghiotto (2017) e Godinho e Cozendei (2015), em 1965, a Convenção de Washington estabeleceu o CIADI, entidade afiliada ao Banco Mundial, que pretendia prover um espaço para arbitragem de disputas entre um investidor e o país anfitrião. No contexto da Guerra Fria e dos processos de descolonização no chamado Terceiro Mundo, alegava-se que os sistemas judiciais nacionais não seriam imparciais e que os foros internacionais seriam isentos de interferência política. Porém, isso resultou em que o investidor estrangeiro não mais esgotasse os foros nacionais antes de recorrer à arbitragem internacional. Notoriamente, apenas o investidor pode iniciar um processo arbitral com base no tratado, o Estado apenas responde. 0 Brasil não assinou a Convenção de Washington, mas a maioria dos países da América Latina sim, sendo a Argentina o país que mais responde a casos iniciados por empresas multinacionais, somando 62. Observamos que Bolívia, Equador e Venezuela renunciaram à Convenção de Washington, e o Equador realizou uma auditoria cidadã dos acordos internacionais de investimento. Disponível em: <https://investmentpolicy.unctad.org/investment-dispute-settlement/country/8/argentina>. 
realizaram revisóes em normas sobre investimento estrangeiro, viabilizando a livre transferência de recursos investidos no país (Morosoni e Xavier Júnior, 2015). Além disso, como parte do Mercosul, o Brasil seguiu em negociaçóes sobre livre comércio com Israel, Egito e Marrocos, incluindo cláusulas sobre investimentos. Assim, "esses dados mostram que a inexistência de TBIs não significa que o Brasil não tenha mantido um arcabouço de segurança jurídica para o IED” (Arroyo e Ghiotto 2017, p. 40, tradução nossa).

O quadro muda, entretanto, com a crescente expansão internacional de empresas brasileiras nos anos 2000. O governo brasileiro passou a rever sua posição no regime internacional de investimento, uma vez que, agora, visava proteger e promover suas próprias empresas no exterior. Morosini e Ratton (2015) apontam que essa mudança se deu com ampla consulta ao setor privado. No início dos anos 2000, após o arquivamento dos projetos pelo Congresso Nacional, a Câmara de Comércio Exterior (CAMEX) instituiu um grupo de trabalho interministerial, que recomendou a renegociaçáo dos acordos com os parceiros estratégicos para o Brasil. Um novo modelo de tratado deveria conter "linguagens alternativas" (Morosini e Xavier Júnior, 2015, p. 433). Em 2007, o Conselho de Ministros da CAMEX aprovou diretrizes de negociação, sugerindo: "(a) a renegociação dos acordos de investimento no âmbito do Mercado Comum do Sul (MERCOSUL); (b) a negociaçáo prioritária de acordos de investimento com países da América do Sul e (c) a negociação fora da região apenas no contexto de acordos comerciais mais amplos" (idem, ibidem). Portanto, havia um direcionamento para estabelecer acordos de investimentos com países africanos e latino-americanos, respondendo à reivindicação do setor privado brasileiro de um arcabouço normativo de proteção aos seus ativos nestas regiôes. Finalmente, em 2015, as negociaçóes do novo acordo foram concluídas com Angola, Moçambique, Malaui e México, seguidas de negociaçóes com outros países.

Esse processo revela que o ACFI não tem uma relação direta com o volume de investimento em si - os rankings que mapeiam o investimento direto brasileiro mostram que empresas brasileiras investiram prioritariamente na América Latina e Caribe, além de Estados Unidos e países europeus (FDC, 2016; CNI, 2016) -, mas sim com interesses estratégicos do governo brasileiro, bem como o histórico da atuação de empresas multinacionais brasileiras, que enfrentaram disputas e conflitos. ${ }^{8}$

Assim, naquele primeiro momento, o novo modelo brasileiro parece ter sido desenhado para promover e proteger investimentos brasileiros em outras economias em desenvolvimento, e não necessariamente atrair corporaçóes multinacionais para investir no Brasil. Hoje, entretanto, esse objetivo parece mudar, na medida em que o Brasil se insere no debate sobre facilitaçáo de investimentos em organismos multilaterais, como a OCDE e a Organização Mundial do Comércio (OMC), e a instância do ombudsman na CAMEX

8. Existe ampla documentação de organizações da sociedade civil e acadêmicas sobre impactos referentes à atuação da Vale em Moçambique, particularmente no que tange ao reassentamento forçado de mais de mil famílias em Moatize, província de Tete, que implicou a perda de acesso a terras apropriadas para a agricultura, afastamento dos centros de vendo de produtos agrícolas, problemas da edificação das casas construídas para as famílias, bem como questões relativas às condições de trabalho nas plantas de carvão (Cezne, 2019; Marshall, 2015; Articulação Nacional dos Atingidos pela Vale, 2012; HRW, 2013). Desde 2014, a Vale vem vendo ativos e se retirando de Moçambique em um processo que se finaliza em 2021 (Disponível em: <http://www.vale.com/mozambique/pt/aboutvale/news/paginas/vale-assina-acordopara-adquirir-participacao-da-mitsui-em-moatize-e-cln.aspx>). No caso da América do Sul, houve casos de disputas entre governos e conflitos com atores sociais envolvendo empresas de construção civil, como a Odebrecht e a Petrobras (Delgado, 2017; Zibechi, 2013; Instituto Rosa Luxemburg Stiftung et al., 2009). 
passa a operar para facilitar a entrada e instalaçáo de operaçóes de comércio e investimentos no Brasil, além do interesse do atual governo brasileiro em negociar com países desenvolvidos. ${ }^{10}$

Morosini e Xavier Júnior (2015) sintetizam as principais características do novo modelo de acordo, que contempla mecanismos para a prevenção (e não somente solução) de controvérsias, uma melhoria da governança institucional, bem como cláusulas de responsabilidade social corporativa. Com essas características, o ACFI apresenta mudanças substantivas em comparação com os TBIs tradicionais, tais como:

a) limita os investimentos cobertos e exclui explicitamente os investimentos em carteira ou especulativos;

b) limita a retroatividade dos investimentos antes da assinatura; c) exclui a chamada expropriaçáo indireta;

d) contém salvaguardas para manter a possibilidade de regulamentação prudencial no setor financeiro;

e) aprimora o mecanismo de soluçáo de controvérsias, especialmente ao incluir a possibilidade de os investidores serem avaliados por seu desempenho; f) incorpora um quadro institucional próprio de forma a garantir o cumprimento dos objetivos do acordo e a minimizar os conflitos; g) limita o alcance de algumas das cláusulas; h) limita a cláusula de sobrevivência a um máximo de um ano (Arroyo e Ghiotto, 2017, p. 50, tradução nossa).

Por fim, é relevante observar que o surgimento do ACFI se enquadra no contexto mais amplo de reformas nos modelos de tratados, que resultou em uma nova geração de acordos de proteção e facilitação de investimentos a partir dos anos 2010. Além do Brasil, países como Equador, Noruega, África do Sul, Índia, Indonésia e Austrália também iniciaram um processo de revisão das estruturas estabelecidas para a negociação de tratados de investimento (Arroyo e Ghiotto, 2017). Segundo a UNCTAD (2018), esses tratados da "nova geração" contêm: orientação ao desenvolvimento sustentável (como a proteção humana e da saúde, proteção animal, direitos trabalhistas, desenvolvimento ambiental e sustentável, etc.); preservação do espaço regulatório, minimizando a exposição à arbitragem internacional (como a limitação do escopo do tratado, mais detalhamentos sobre expropriaçáo indireta e cláusula de exceção); e uma regulação mais cuidadosa sobre resolução de controvérsias, excluindo ou restringindo a cláusula investidor-Estado a algumas áreas (UNCTAD, 2018). Notoriamente, o Protocolo de Facilitação de Investimentos do Mercosul, que espelha o modelo brasileiro de ACFI, incluiu todos os novos elementos dos modernos tratados de investimento, favorecendo, segundo a UNCTAD (2018, p. 5), "investimentos responsáveis".

\section{ANGOLA E MOÇAMBIQUE: O ACFI EM PERSPECTIVA COMPARADA}

O momento de reformas no regime internacional de investimentos também envolveu os países africanos. Alguns deles deram início a reformas nas suas legislações domésticas, além de conduzir negociações com modelos de TBIs já modernizados. Adicionalmente, os países africanos estão envolvidos em um conjunto de acordos regionais com disposiçôes sobre investimentos e livre comércio. Angola e Moçambique já vinham experimentando um declínio na entrada de investimento externo direto nos últimos anos, particularmente por conta da queda no preço do petróleo e de outras commodities. Esses países têm inserçôes distintas no regime internacional de investimentos: enquanto Angola tem um número reduzido de TBIs e não é membro do CIADI, Moçambique está enredado em um conjunto

\footnotetext{
9. Disponível em: <http://www.camex.gov.br/investimentos/ombudsman-de-investimentos-diretos-oid>.

10. Notamos que as mudanças de prioridades da política externa brasileira podem resultar em um acordo sobre comércio e investimentos com países centrais, como os Estados Unidos. Disponível em: <https:/www.atlanticcouncil.org/wp-content/uploads/2020/06/EUA-Brasil_Comercioe-Investimentos_Atlantic-Council.pdf>.
} 
de TBIs e foi levado à arbitragem do CIADI em dois casos. Ao mesmo tempo, Angola reformou sua legislação nacional de investimentos ${ }^{11}$ e Moçambique fez reformas em legislaçôes setoriais. ${ }^{12}$

Angola é signatária de dezoito tratados bilaterais de investimento, com seis acordos em vigor, como mostra o quadro 2. Além destes, o país é parte de outros seis tratados com disposiçôes sobre investimentos, dos quais cinco estáo em vigor: Acordo de Cotonou, Tratado da Comunidade Econômica dos Estados da África Central (CEEAC), Tratado da Comunidade de Desenvolvimento da África Austral (SADC), Protocolo de Investimento da SADC e Acordo Europeu de Parceria EU-SADC. ${ }^{13}$ Em comparação com outros países africanos, Angola apresenta um número relativamente baixo de TBIs assinados, bem abaixo de países como Moçambique, Senegal e Etiópia (UNCTAD, 2019).

QUADRO 2

Acordos de investimentos de Angola

\begin{tabular}{|c|c|c|}
\hline País & Assinado em & Em vigor desde \\
\hline São Tomé e Príncipe & 31/3/1995 & - \\
\hline Itália & 10/7/1997 & 21/5/2007 \\
\hline Cabo Verde & 11/9/1997 & 15/12/1997 \\
\hline Portugal & 24/10/1997 & $20 / 4 / 2020$ \\
\hline Reino Unido & 4/7/2000 & - \\
\hline Alemanha & $30 / 10 / 2003$ & $1 / 3 / 2007$ \\
\hline Namíbia & $21 / 3 / 2004$ & - \\
\hline África do Sul & 17/2/2005 & - \\
\hline Guiné-Bissau & 11/10/2007 & - \\
\hline Espanha & 21/11/2007 & - \\
\hline Portugal & $22 / 2 / 2008$ & - \\
\hline Cuba & 20/5/2008 & - \\
\hline França & $24 / 6 / 2008$ & - \\
\hline Rússia & $26 / 6 / 2009$ & $12 / 1 / 2011$ \\
\hline Congo & 9/9/2010 & - \\
\hline Brasil & 1/4/2015 & 28/7/2017 \\
\hline Moçambique & 9/11/2015 & - \\
\hline Emirados Árabes Unidos & $5 / 4 / 2017$ & - \\
\hline
\end{tabular}

Fonte: UNCTAD. Disponivel em: <https://investmentpolicy.unctad.org>.

Elaboração dos autores.

A maioria dos acordos angolanos reflete o modelo tradicional dos TBIs, incluindo disposiçóes sobre tratamento nacional (com exceçóes pontuais nos TBIs com Rússia, África do Sul e Alemanha ${ }^{14}$ ), cláusulas sobre solução de controvérsias e arbitragem investidor-Estado, recorrendo às regras da

11. Em 2018, Angola aprovou a nova Lei de Investimento Privado, que estabeleceu novas bases para o tratamento do IED no país e a criação da Agência de Investimento Privado e Promoção das Exportações (AIPEX).

12. A principal legislação relativa a investimentos nacionais e estrangeiros em Moçambique refere-se à Lei de Investimentos, adotada em 1993, e ao Regulamento da Lei de Investimentos, adotado em 2009. Nesse sentido, Moçambique se difere de outros países africanos que, tal como Angola e África do Sul, reformaram suas legislações nacionais sobre investimentos. Ao mesmo tempo, o país adotou regulamentos setoriais mais recentes, como a Lei de Petróleo e Gás e a Lei de Minas, ambas de 2014.

13. Angola tem um acordo-quadro de comércio e investimentos com os Estados Unidos, assinado em 2009, que não está em vigor. Disponível em: <https://investmentpolicy.unctad.org/international-investment-agreements/countries/5/angola>.

14. O TBI com a Alemanha exclui do tratamento nacional medidas tomadas com base em segurança, ordem, saúde pública e moralidade. No TBI com África do Sul, há exceç̃̃es ao tratamento nacional para medidas adotadas para alcançar igualdade em território sul-africano; já no TBI com a Rússia, há exceções para acordos feitos com países da antiga União Soviética. 
Comissão das Nações Unidas para o Direito Comercial Internacional (UNCITRAL) ou às Regras do Mecanismo Complementar do CIADI ${ }^{15}$ - com a exceção do ACFI com o Brasil, que prevê apenas a arbitragem Estado-Estado como último recurso (UNCTAD, 2019). Entretanto, não há casos divulgados de arbitragem investidor-Estado sob a égide dos TBIs angolanos.

Por sua vez, Moçambique registra 28 tratados bilaterais de investimento assinados, com vinte acordos em vigor, como demonstra o quadro 3. Além dos 28 TBIs, Moçambique é signatária de oito tratados com provisões sobre investimentos, dos quais seis estão em vigor: o Protocolo de Investimento da SADC; Acordo-Quadro de Comércio e Investimento EUA-Moçambique; Acordo de Cotonou; Tratado da SADC; Tratado da União Africana; e Acordo de Proteção de Investimentos da Organização para a Cooperação Islâmica. ${ }^{16}$

\section{QUADRO 3}

\section{Acordos de investimentos de Moçambique}

\begin{tabular}{|c|c|c|}
\hline País & Assinado em & Em vigor desde \\
\hline Zimbábue & 12/9/1990 & - \\
\hline Portugal & 28/5/1996 & $31 / 1 / 1998$ \\
\hline Ilhas Maurício & 14/2/1997 & $26 / 5 / 2003$ \\
\hline África do Sul & 6/5/1997 & - \\
\hline Estados Unidos & 1/12/1998 & $3 / 3 / 2005$ \\
\hline Egito & 8/12/1998 & - \\
\hline Argélia & 12/12/1998 & $25 / 7 / 2000$ \\
\hline Itália & 14/12/1998 & $17 / 11 / 2003$ \\
\hline Indonésia & 26/3/1999 & $25 / 7 / 2000$ \\
\hline China & $10 / 7 / 2001$ & $26 / 2 / 2002$ \\
\hline Cuba & 20/10/2001 & $26 / 2 / 2002$ \\
\hline Suécia & 23/10/2001 & $1 / 11 / 2007$ \\
\hline Países Baixos & $18 / 12 / 2001$ & $1 / 9 / 2004$ \\
\hline Alemanha & $6 / 3 / 2002$ & 15/9/2007 \\
\hline Dinamarca & $12 / 10 / 2002$ & $30 / 12 / 2002$ \\
\hline França & $15 / 11 / 2002$ & $6 / 7 / 2006$ \\
\hline Suíça & $29 / 11 / 2002$ & $17 / 2 / 2004$ \\
\hline Emirados Árabes Unidos & $24 / 9 / 2003$ & - \\
\hline Reino Unido & $18 / 3 / 2004$ & $12 / 5 / 2004$ \\
\hline Finlândia & $3 / 9 / 2004$ & $21 / 9 / 2005$ \\
\hline União Econômica Bélgica-Luxemburgo (BLEU) & $18 / 7 / 2006$ & $1 / 9 / 2009$ \\
\hline Vietnã & $16 / 1 / 2007$ & $29 / 5 / 2007$ \\
\hline Índia & 19/2/2009 & 23/9/2009 \\
\hline Japão & $1 / 6 / 2013$ & $29 / 8 / 2014$ \\
\hline Brasil & $30 / 3 / 2015$ & - \\
\hline Angola & 9/11/2015 & - \\
\hline Singapura & $24 / 8 / 2016$ & - \\
\hline Turquia & $24 / 1 / 2017$ & - \\
\hline
\end{tabular}

Fonte: UNCTAD. Disponível em: <https://investmentpolicy.unctad.org>.

Elaboração dos autores.

15. Embora Angola não seja membro do CIADI, diversos Alls permitem recurso à arbitragem investidor-Estado sob as Regras do Mecanismo Complementar do CIADI (UNCTAD, 2019).

16. 0 Acordo Interino EU-SADC e Acordo de Parceria Econômica EU-SADC não estão em vigor. Disponível em: <https://investmentpolicy. unctad.org/international-investment-agreements/countries/143/mozambique?type=bits > . 
Embora a arbitragem investidor-Estado esteja presente na grande maioria dos TBIs moçambicanos, apenas dois casos foram registrados junto ao CIADI. O mais recente foi em 2017, quando a empresa italiana de construção civil CMC iniciou processo contra Moçambique no marco do TBI Moçambique-Itália. $\mathrm{O}$ caso se refere ao não pagamento de valores adicionais supostamente acordados pela Administração Nacional de Estrada para a reconstrução de trecho da principal rodovia Norte-Sul em Moçambique. Em 2019, foi emitida decisão favorável ao governo de Moçambique, entendendo que não houve violação de nenhuma disposição do TBI. ${ }^{17} \mathrm{O}$ outro caso foi registrado em 2014 pelo empresário sul-africano Oded Besserglik contra o governo de Moçambique, no marco do TBI Moçambique-África do Sul. O caso baseia-se em quebras contratuais realizadas pelas estatais moçambicanas Empresa Moçambicana de Pescas (EMOPESCAS) e Sociedade de Pescas do Sul (SULPESCA). Porém, o processo foi indeferido pelo CIADI por julgar que o tribunal não possuía jurisdiçáo sobre a matéria, uma vez que o TBI não havia entrado em vigor. ${ }^{18}$

Examinando os textos dos ACFIs com Moçambique e Angola, apresentamos aqui algumas observaçôes. Eles mantêm cláusulas similares aos TBIs tradicionais (que, no geral, correspondem às regras da $\mathrm{OMC}$ ), tais como são o tratamento nacional ao investidor estrangeiro e o princípio da naçáo mais favorecida. ${ }^{19}$ Da mesma forma que os TBIs tradicionais, os acordos brasileiros asseguram a proteçấo de todos os investimentos feitos antes e depois da sua ratificação. No que diz respeito à definiçáo de investimentos e de investidores, o ACFI com Angola prevê que essas definiçóes devem estar de acordo com as leis nacionais, enquanto o ACFI com Moçambique contempla investimentos em produção e serviços. A propriedade intelectual é abordada no âmbito da OMC. Os acordos asseguram o fluxo livre de capital, exceto quando o litígio é iniciado ou há uma crise no balanço de pagamentos, de acordo com as regras do Fundo Monetário Internacional. As expropriaçóes e as nacionalizaçóes são permitidas em caso de utilidade e interesse público, de forma não discriminatória e mediante indenização adequada e efetiva, com base no valor justo de mercado referente à data da expropriaçáo.

Porém, diferentemente dos TBIs tradicionais, os ACFIs com Angola e com Moçambique não fazem menção a medidas equivalentes às expropriaçóes, que seriam expropriaçóes indiretas, ou que poderiam atingir "expectativas legítimas" da empresa. ${ }^{20}$ Outra caraterística distintiva do ACFI é a governança institucional criada para coordenar e executar o acordo. Ela é composta por um comitê conjunto, que opera como um órgão diretivo, formado pelos governos dos dois países, com a função de debater, monitorar e coordenar a expansão dos investimentos. Seu órgão executor é o ombudsman, composto por pontos focais dos países: no Brasil, a CAMEX; no caso de Angola, a Secretaria de Estado para a Cooperaçáo do Ministério das Relaçóes Exteriores; no caso de Moçambique, o Conselho de Investimentos. Esses pontos focais irão atender às orientaçóes do comitê e efetivamente atuar na execução do acordo, trocando informaçóes, atuando junto aos atores da outra parte, prevendo e facilitando a resoluçáo de disputas. Vale notar que os textos dos acordos afirmam promover a participaçáo do setor privado nesse processo. ${ }^{21}$

17. Disponível em: <https://icsid.worldbank.org/cases/case-database/case-detail?CaseNo=ARB/17/23>.

18. Disponível em: <https://icsid.worldbank.org/cases/case-database/case-detail?CaseNo=ARB\%28AF\%29/14/2>.

19. 0 ACFI exclui do princípio da nação mais favorecida preferências e privilégios concedidos em caso de união aduaneira, zonas de livre comércio e tratados para evitar a dupla tributação.

20. Essa caraterística também aparece no TBI de Moçambique com a Holanda. Em todos os demais acordos moçambicanos, é prevista a compensação para investidores no caso de medidas indiretas "equivalentes" à expropriação - embora apenas os TBls com Itália e Estados Unidos apresentem detalhes adicionais sobre a caracterização de expropriação indireta.

21. Um mecanismo similar aparece no caso do TBI de Moçambique com o Japão, em que é previsto o estabelecimento de um comitê conjunto com competência para promover a troca de informações entre as partes sobre ambientes de negócios e realizar reuniões junto ao setor privado. 
Neste sentido, o ACFI brasileiro estabelece um procedimento que busca prevenir disputas e mediar os conflitos, mantendo os interesses empresariais brasileiros. Em casos de controvérsia, os pontos focais deverão negociar a indenização e a compensação, em consulta com o setor privado e outras partes envolvidas, levando o caso para decisão final no comitê conjunto. Se a disputa não for solucionada, o caso irá para arbitragem internacional entre os dois Estados. O tribunal será estipulado ad hoc, não contemplando o CIADI como foro.

Consequentemente, o acordo se diferencia da parte mais sensível dos TBIs tradicionais, que é a cláusula investidor-Estado. Em caso de controvérsias envolvendo empresas multinacionais brasileiras nos países africanos, é o Estado brasileiro, e não a empresa, que irá negociar uma solução com o Estado anfitrião. Aqui cabe-nos uma ponderação. Por um lado, é positiva a impossibilidade de o investidor privado ganhar força jurídica equivalente ou maior do que o Estado-nacional. Por outro, é preocupante o risco de desresponsabilização da empresa envolvida, uma vez que é o Estado brasileiro que irá arcar com o ônus político e econômico da disputa. Nesse sentido, os interesses de empresas brasileiras no exterior são representados como o "interesse nacional" e as disputas e conflitos existentes entre a multinacional e o Estado receptor acabam sendo estendidos para o Estado brasileiro. A mescla entre políticas públicas e interesses privados se consolida juridicamente no ACFI (Garcia e Kato, 2016).

Observamos, com isso, que a diplomacia acaba ganhando um grande peso. Nesta direção, Arroyo e Ghiotto (2017) ponderam que a controvérsia levantada por um investidor pode se tornar uma questáo de política externa, podendo resultar em uma politizaçáo da disputa iniciada por um ator privado. Adicionalmente, os autores observam que pode ocorrer uma maior assimetria de poder na resolução de litígios caso esse tipo de acordo venha a ser feito com países mais ricos, como os que compóem o G7.

Adicionalmente, como forma de remediar aspectos mais críticos que permearam os TBIs tradicionais nos anos 1990, os ACFIs com Angola e Moçambique incluem cláusulas de responsabilidade social corporativa em matéria de meio ambiente, direitos humanos e trabalho, uma tendência da nova geração de tratados de investimentos (UNCTAD, 2018). Tais preocupaçóes também aparecem em outros acordos envolvendo Angola e Moçambique: o Acordo Europeu de Parceria entre União Europeia e Comunidade de Desenvolvimento da África Austral (Southern Africa Development Community - SADC) apresentam provisóes voltadas a evitar o enfraquecimento ou redução de níveis nacionais de proteção laboral e do meio ambiente como parte de incentivos a investimentos (UNCTAD, 2019). No caso do Protocolo de Financiamento e Investimento da SADC, também há disposiçóes orientadas ao desenvolvimento sustentável, incluindo referências às responsabilidades. No caso de Moçambique, os TBIs com o Japão e com BLEU, embora não incluam compromissos de responsabilidade social corporativa, incluem capítulos sobre trabalho e meio ambiente, nos quais se desencoraja o enfraquecimento de padróes trabalhistas e ambientais para a atraçáo e facilitação de investimentos.

Os ACFIs do Brasil com Angola e Moçambique estipulam que os investidores desenvolveráo "melhores esforços" para observar princípios voluntários e padróes de conduta empresarial. Não há, entretanto, cláusulas vinculantes que responsabilizam as empresas por violaçóes de direitos humanos e descumprimento de padróes trabalhistas e ambientais - nesse sentido, o Brasil não avança além dos códigos de conduta voluntários existentes. A intenção parece ser a de responder parcialmente a críticas e se afastar de conflitos pré-existentes com empresas brasileiras em Moçambique e Angola.

Arroyo e Ghiotto (2017) levantam questionamentos quanto à operacionalização dessas cláusulas de responsabilidade social: uma empresa estrangeira pode ser processada por violação de seu próprio código 
de ética ou responsabilidade social corporativa? A questáo pode ser levada à arbitragem internacional, via Estado onde opera o investimento? Em outras palavras, a responsabilidade social poderá ser cobrada pelo Estado anfitrião (ou mesmo do país de origem) ou permanecerá relevante apenas para a imagem da empresa, sem efeitos reais para as populaçóes impactadas nos territórios? Em nossa visão, as capacidades de barganha e negociação entre sociedade civil, governos e empresas demonstraráo, em cada caso, a extensáo e os limites deste mecanismo. Nos quadros a seguir buscamos sintetizar as caraterísticas distintivas do ACFI com Angola e Moçambique e os demais acordos firmados por estes países.

\section{QUADRO 4}

Características distintivas do ACFI Brasil-Angola em relação a demais acordos de investimento angolanos

\begin{tabular}{|l|l|l|}
\hline \multicolumn{1}{|c|}{ Disposições } & \multicolumn{1}{|c|}{ ACFI } & \multicolumn{1}{|c|}{ Demais TBIs } \\
\hline Solução de controvérsias & $\begin{array}{l}\text { Arbitragem Estado-Estado como último recurso; mecanismos para } \\
\text { prevenção de conflitos. }\end{array}$ & $\begin{array}{l}\text { Possibilidade de arbitragem investidor-Estado sob regras da } \\
\text { UNCITRAL ou do CIADI. }\end{array}$ \\
\hline Governança & $\begin{array}{l}\text { Facilitação de investimentos via comitê conjunto e pontos focais } \\
\text { com função de ombudsman. }\end{array}$ & Há não disposição explícita. \\
\hline Expropriação & Somente expropriação direta. & Expropriação direta e indireta contemplada. ${ }^{2}$ \\
\hline $\begin{array}{l}\text { Tratamento nacional (TN) ou nação } \\
\text { mais favorecida (NMF) }\end{array}$ & $\begin{array}{l}\text { Não há previsão de TN. NMF nas fases pré-estabelecimento e } \\
\text { pós-estabelecimento do investimento. }\end{array}$ & TN e NMF apenas na fase pós-estabelecimento do investimento. ${ }^{3}$ \\
\hline Tratamento justo e equitativo & Nenhuma disposição. & $\begin{array}{l}\text { Garantia de tratamento justo e equitativo segundo "expectativas } \\
\text { legítimas" do investidor. }\end{array}$ \\
\hline Definição de investimento/investidor & $\begin{array}{l}\text { Definições baseadas nos sistemas jurídicos das } \\
\text { partes contratantes. }\end{array}$ & $\begin{array}{l}\text { Definição abrangente, englobando contratos comerciais, } \\
\text { investimento indireto e especulativo. }\end{array}$ \\
\hline Livre transferência de fundos & $\begin{array}{l}\text { Garantia de livre transferência, com exceção em casos de graves } \\
\text { dificuldades no balanço de pagamentos. }\end{array}$ & Garantia de livre transferência de fundos. ${ }^{4}$ \\
\hline
\end{tabular}

Fonte: UNCTAD (2019).

Elaboração dos autores.

Notas: ${ }^{1}$ Ainda que Angola não seja membro do CIADI, os Alls com Alemanha e Rússia permitem recurso à arbitragem investidor-Estado sob as Regras do Mecanismo Complementar do CIADI. Não há casos de arbitragem investidor-Estado conhecidos publicamente contra Angola.

2 Embora os demais TBls angolanos mencionem medidas indiretas "equivalentes" à expropriação, nenhum define os fatores a serem considerados por tribunais ao analisar a existência de expropriação indireta.

${ }^{3} \mathrm{O}$ tratamento nacional ao investidor estrangeiro em Angola é restrito a apenas alguns setores. As cláusulas da nação mais favorecida e do tratamento nacional preveem exceções relativas a acordos internacionais que estabelecem mercados comuns, áreas de livre comércio e uniões aduaneiras e acordos tributários.

${ }^{4}$ Além do ACFI brasileiro, a única outra exceção à livre transferência de fundos ocorre no All com a África no Sul, onde a livre transferência não se aplica a indivíduos angolanos ou sul-africanos que sejam residentes permanentes de ambos os países.

\section{QUADRO 5}

Características distintivas do ACFI Brasil-Moçambique em relação a demais acordos de investimento moçambicanos

\begin{tabular}{|l|l|l|}
\hline \multicolumn{1}{|c|}{ Disposição } & \multicolumn{1}{|c|}{ ACFI } & \multicolumn{1}{|c|}{ Demais TBIs $^{1}$} \\
\hline Solução de controvérsias & $\begin{array}{l}\text { Arbitragem Estado-Estado como último recurso; } \\
\text { mecanismos para prevenção de conflitos. }\end{array}$ & Possibilidade de arbitragem investidor-Estado sob regras do CIADI. \\
\hline Governança & $\begin{array}{l}\text { Facilitação de investimentos via comitê conjunto e } \\
\text { pontos focais com função de ombudsman. }\end{array}$ & Exceto TBI com Japão, nenhuma disposição explícita. \\
\hline Expropriação & Somente expropriação direta. & Exceto TBI com Holanda, expropriação direta e indireta contemplada. \\
\hline Responsabilidade social corporativa & Compromissos não vinculantes e princípios voluntários. & Exceto TBI com Japão e BLEU, ${ }^{2}$ nenhuma disposição. \\
\hline Tratamento justo e equitativo & Nenhuma disposição. & Garantia de tratamento justo e equitativo para investidores estrangeiros. \\
\hline Definição de investimento/investidor & Definição abrangente, detalhada no artigo 3 do acordo. & $\begin{array}{l}\text { Definição abrangente, englobando contratos comerciais, investimento } \\
\text { indireto e especulativo. }\end{array}$ \\
\hline
\end{tabular}

Fonte: UNCTAD. Disponível em: <https://investmentpolicy.unctad.org>.

Elaboração dos autores.

Notas: ${ }^{1}$ A comparação abrange os dezessete TBls publicamente disponíveis: África do Sul, Alemanha, Argélia, BLEU, Estados Unidos, Finlândia, França, Holanda, Ilhas Maurício, Índia, Indonésia, Itália, Japão, Portugal, Reino Unido, Suécia e Suiça.

2 Os TBIs com Japão e BLEU incluem capítulos sobre trabalho e meio ambiente, mas não é utilizado o termo responsabilidade social. 


\section{CONCLUSÃO}

Neste trabalho, resgatamos o surgimento do Acordo de Cooperação e Facilitação de Investimentos do Brasil no contexto de reformas dos modelos de tratados bilaterais de investimentos, e fizemos um balanço do ACFI com Angola e Moçambique, apresentando um quadro comparativo com os demais tratados bilaterais de investimentos em vigor com cada um destes países.

Os tratados bilaterais de investimentos foram moldados pelo contexto histórico do pós-guerra, as disputas geopolíticas da Guerra Fria e os movimentos por descolonização de países na África e Ásia. Com a abertura de mercados e o período da globalização nos anos 1990, os tratados bilaterais de investimento adquiriram abrangência realmente global. Além disso, os TBIs passaram a ser, além de acordos entre países majoritariamente assimétricos, também parte das relaçóes entre países do Sul Global, tal como o acordo entre o Brasil e países africanos.

Nos últimos anos, foram levantadas crescentes críticas de natureza política, econômica e social diante dos efeitos dos tratados sobre as políticas públicas dos países signatários. Sustentamos que os TBIs tradicionais refletem o poder estrutural de empresas multinacionais, característico da ordem mundial capitalista sob hegemonia das potências ocidentais, resultando em constrangimentos vinculantes internacionais sobre os Estados-nacionais, e limitando seu escopo de ação para políticas públicas em temas de interesse abrangente como questóes de direitos humanos, sociais e ambientais. Tais críticas e questionamentos levaram ao contexto atual de reformas, sendo considerado pela UNCTAD uma "nova geração de acordos", no qual se insere o ACFI do Brasil.

O caso do Brasil evidenciou que a inexistência de TBIs não significa a redução da entrada de IED ou a insegurança jurídica ao investidor. O país não havia ratificado, nos anos 1990, tratados de investimentos, mas reformou sua legislação nacional para conferir garantias ao investidor estrangeiro. Hoje, entretanto, o Brasil mudou de posição diante da crescente expansão internacional de empresas brasileiras, objetivando, agora, proteger e promover suas próprias empresas no exterior. Em 2015, os três primeiros ACFIs foram assinados precisamente com países africanos, em particular Angola e Moçambique, além do Malaui. Argumentamos que o início do ACFI com esses países refletiu, naquele momento, interesses estratégicos do governo brasileiro, bem como o histórico da atuação de empresas multinacionais brasileiras, que enfrentaram disputas e conflitos.

O ACFI trouxe aspectos inovadores que atenuam os elementos críticos dos TBIs tradicionais, particularmente mecanismos para a prevenção de controvérsias e uma nova governança institucional, bem como cláusulas de responsabilidade social corporativa. Por sua vez, ponderamos que pode haver um risco de desresponsabilizaçáo de empresas envolvidas, na medida em que é o Estado brasileiro que arcará com o ônus político e econômico da disputa. Nesse sentido, as disputas e conflitos existentes entre a multinacional e o Estado anfitriáo podem tornar-se uma questáo de política externa.

Observamos que Angola e Moçambique já mantinham TBIs com diferentes países do mundo, mas com graus distintos de inserção no regime internacional de investimentos. Em ambos os países, há aspectos críticos que envolvem disputas relativas ao acesso à terra e impactos dos megaprojetos. Há posições distintas entre governo, comunidades e organizações sociais envolvendo grandes projetos de investidores estrangeiros. Com isso, o Brasil deve observar com sensibilidade esses processos sociais, considerando aspectos históricos, políticos, sociais e ambientais nos territórios onde os projetos planejam ser implementados. A implementação do ACFI deverá ser monitorada para que tenha efeitos positivos no sentido de investimentos social e ambientalmente responsáveis, tal como o modelo brasileiro se propóe. 


\section{REFERÊNCIAS}

ARROYO, A.; GHIOTTO, L. Brasil y la nueva generación de Acuerdos de Cooperación y Facilitación de Inversiones: un análisis del Tratado con México. Relaciones Internacionales, n. 26, v. 52, 2017.

ARTICULAÇÃO INTERNACIONAL DOS ATINGIDOS PELA VALE. Relatório de Insustentabilidade da Vale 2012. [s.l.]: Articulação Internacional dos Atingidos pela Vale, 2012. Disponível em: <https:// atingidosvale.com/wp-content/uploads/2020/11/relatorio-insustentabilidade-vale-2012-final1.pdf>.

CEZNE, E. Forging transnational ties from below: challenging the Brazilian mining giant Vale S. A. across the South Atlantic. The Extractive Industries and Society, n. 6, p. 1174-1183, 2019.

CNI - CONFEDERAÇÃO NACIONAL DA INDÚSTRIA. Os investimentos brasileiros no exterior 2015: a governança internacional dos investimentos: acordos e regras aplicáveis aos investimentos. Brasília: CNI, 2016. Disponível em: <https://static.portaldaindustria.com.br/media/filer_public/c8/9f/c89fb4fc-d9304d10-854b-4e523cc241ef/investimentos_brasileiros_no_exterior_2015.pdf>.

DELGADO, A. C. The TIPNIS conflict in Bolivia. Contexto Internacional, v. 39, n. 2, May./Aug. 2017.

FDC - FUNDAÇÃO DOM CABRAL. Ranking FDC das multinacionais brasileiras Rio de Janeiro: FDC, 2016. Disponível em: <https://www.fdc.org.br/conhecimento-site/nucleos-de-pesquisa-site/centro-de-referenciasite/Materiais/Ranking_FDC_Multinacionais_Brasileiras_2016.pdf>.

GARCIA, A.; KATO, K. Políticas públicas e interesses privados: uma análise a partir do Corredor de Nacala em Moçambique. Caderno CRH, v. 29, p. 69-86, 2016.

GODINHO, D.; COZENDEI, C. Novos acordos de investimento no menu. Valor Econômico, 24 jul. 2015.

HERNANDEZ, J. El nuevo poder corporativo. Amsterdam: State of Power; Transnational Institute, 2015. Disponível em: <https://bit.ly/2SjMRHb>.

HRW - HUMAN RIGHTS WATCH. What is a house without food? Mozambique's coal mining boom and resettlements. [s.l.], HRW, 2013. Disponível em: <http://www.hrw.org/sites/default/files/reports/ mozambique0513_Upload_0.pdf>.

INSTITUTO ROSA LUXEMBURG STIFTUNG et al. (Org.). Transnacionais brasileiras na América Latina: um debate necessário. São Paulo: Expressão Popular, 2009.

MARSHALL, J. The worst company in the world. Jacobin Magazin, 11 dez. 2015. Disponível em: <https:// www.jacobinmag.com/2015/11/vale-corporation-brazil-mining-lula-mozambique-brics>.

MOROSINI, F.; RATTON, M. The Brazilian Agreement on Cooperation and Facilitation of Investments (ACFI): a new formula for international investment agreements? Investment Treaty News, 4 ago. 2015.

MOROSINI, F.; XAVIER JÚNIOR, E. C. Regulação do investimento estrangeiro direto no Brasil: da resistência aos tratados bilaterais de investimento à emergência de um novo modelo regulatório. Revista de Direito Internacional, Brasília, v. 12, n. 2, p. 420-447, 2015.

MÜLLER, B.; OLIVET, C. Impacts of investment arbitration against African States. Amsterdam: TNI, 2019. (ISDS in Numbers). Disponível em: <https://www.tni.org/files/publication-downloads/isds_africa_web.pdf>.

VANDEVELDE, K. J. A brief history of international investment agreements. In: SAUVANT, K. P.; SACHS, L. E. (Eds.). The effects of treaties on foreign direct investments. New York: Oxford University Press, 2009.

UNCTAD - UNITED NATIONS CONFERENCE ON TRADE AND DEVELOPMENT. World Investment Report 2015: reforming international investment governance. Geneva: UNCTAD, 2015. (Chapter IV). Disponível em: <https://unctad.org/system/files/official-document/wir2015ch4_en.pdf>.

. Recent developments in the international investment regime. International Investments Agreement: IIA Issues Note, issue 1, May 2018. 
Investment policy review: Angola. [s.l.]: UNCTAD, 2019.

ZIBECHI, R. Brasil Potencia: entre la integración regional y un nuevo imperialismo. Lima: PDTG/FSP, 2013.

ZUBIZARRETA, J. H. El nuevo poder corporativo. Estado del Poder, Marzo 2015. Disponível em: <https:// www.tni.org/files/download/01_tni_estado_del_poder_2015_el_nuevo_derecho_corporativo_global.pdf>. 


\title{
INVESTIMENTO EXTERNO DIRETO NA AMÉRICA LATINA: O PAPEL DOS ACORDOS DE INVESTIMENTO
}

\author{
Ignácio Tavares de Araújo Júnior ${ }^{1}$
}

\begin{abstract}
SINOPSE
Com exceção do Brasil, os países da América Latina aumentaram consideravelmente suas redes de tratados bilaterais de investimento (TBIs) durante os anos 1990, na busca de ampliar o ingresso de investimento externo direto (IED). Apesar da teoria sobre o tema prever uma relação positiva entre o ingresso de IED e a celebração desses acordos, a literatura empírica não é conclusiva sobre que impactos os TBls exercem sobre o IED, tornando questionáveis os efeitos que esses acordos geraram nas decisões de investimento para a região. Este artigo contribui para a literatura sobre o tema ao analisar como esses acordos têm contribuído para o volume de IED greenfield nos países da América Latina. Um modelo gravitacional foi estimado com essa finalidade, e os resultados indicam que, para os países da América Latina, os TBIs não têm efeito estatisticamente significativo sobre o IED. Os tamanhos das economias, o crescimento econômico, o grau de abertura comercial e a similaridade do retorno do capital têm explicado por que esse tipo de IED tem sido direcionado para os países da região. Evidenciou-se ainda que países com melhor qualidade regulatória atraem mais IED. Países que ratificaram os TBls mas responderam por alguma reclamação em tribunal de arbitragem têm seus fluxos de investimento reduzidos. Por fim, levando em conta os efeitos fixos setoriais, a estimação do modelo gravitacional sugeriu que os TBIs não têm efeito positivo em investimentos nos setores industrial, de serviços e os relacionados à extração de recursos naturais.
\end{abstract}

Palavras-chave: tratados de investimento; investimento externo direto; modelo gravitacional; América Latina.

\begin{abstract}
Except for Brazil, Latin American countries considerably expanded their bilateral investment treaties (BITs) networks during the 1990s, in an attempt to increase FDI inflows. Although the theory on the subject predicts a positive relationship between the inflow of FDI and the conclusion of these agreements, the empirical literature is not conclusive about what impacts TBIs have on FDI, making uncertain the effects that these agreements have had on investment decisions in the region. This article contributes to the literature by analyzing the extent to which these agreements have contributed to the volume of greenfield FDI in Latin American countries. A gravitational model has been estimated for this purpose and the results indicate that for Latin American countries TBIs have no statistically significant effect on FDI. The size of economies, economic growth, trade openness, the similarity in return on capital has explained why this type of FDI has been directed to countries in the region. It was also evident that countries with better regulatory quality attract more FDI. Countries that have ratified most TBI but have responded to some claims in arbitration courts have their investment flows reduced. Finally, taking sectoral fixed effects into account, the estimation of the gravitational model suggested that TBIs have no positive effect on investments in the industrial, services and natural resource extraction sectors.
\end{abstract}

Keywords: investment treaties; foreign direct investment; gravity model; Latin America.

JEL: F21; F23; N4.

Artigo recebido em 18/12/2020 e aprovado em 1/2/2021.

DOI: http://dx.doi.org/10.38116/bepi29art8

\footnotetext{
1. Professor do Departamento de Economia da Universidade Federal da Paraíba (DE-UFPB); pesquisador do Laboratório de Economia e Modelagem Aplicada (LEMA) da UFPB; doutor em economia pelo programa de pós-graduação em economia da Universidade Federal de Pernambuco (Pimes-UFPE). E-mail: <ignacio.tavares@gmail.com>.
} 


\section{INTRODUÇÃO}

Um tratado bilateral de investimento (TBI) é um acordo entre dois países que estabelece o tratamento dispensado ao investimento realizado num dos países por uma empresa do outro país. Eles foram concebidos inicialmente para garantir segurança jurídica adicional para os investimentos realizados por empresas dos países desenvolvidos nos países em desenvolvimento (UNCTAD, 2000). De acordo com Hallward-Driemeier (2003), Neumayer e Spess (2005), Guzman (2009) e Kohler e Stähler (2016), a adoção de acordos bilaterais de investimentos é resposta para problemas de hold-up (comportamento oportunista) ou de inconsistência dinâmica nos países em desenvolvimento tentando atrair investimentos externos diretos (IEDs), principalmente quando este envolve custos irrecuperáveis.

Os TBIs dariam maior segurança ao IED, prevendo vultosas indenizaçóes aos investidores, caso houvesse expropriaçôes diretas e indiretas por parte do país receptor do investimento. De acordo com Kerner (2009), para o país hospedeiro do IED, a assinatura do TBI pode atrair investimentos de outros países com os quais náo possui acordo, pois o tratado dificulta a aplicação de leis dos países receptores do investimento que poderiam ser interpretadas como expropriação. Nessa direção, Neumayer e Spess (2005) argumentam que a assinatura de TBIs envia um sinal para potenciais investidores de que o país em desenvolvimento é geralmente sério sobre a proteção do investimento estrangeiro, demonstrando assim seu compromisso com os direitos de propriedade de investidores externos. Para os países em desenvolvimento, muitos deles apresentando instituiçóes frágeis ou sem a reputação dos países já desenvolvidos, os TBIs eram vistos como substitutos para as instituiçóes locais.

Diante das evidências de que o sólido contexto institucional é importante para atrair IED (Bénassy-Quéré, Coupet e Mayer, 2007), os países em desenvolvimento buscaram celebrar TBIs ao redor do mundo durante os anos 1990, na expectativa de se tornarem mais atrativos para o IED e devido aos potenciais benefícios desse tipo de investimento em termos de geração de empregos, assimilação de novas tecnologias e crescimento econômico.

Seguindo essa tendência mundial, na América Latina, à exceção do Brasil, ${ }^{2}$ todos os países ratificaram acordos de investimento durante os anos 1990 e início dos anos 2000.

Os países da região possuem um histórico de instabilidade em suas instituiçóes, e a ratificação de TBIs pode ter sido uma opção para oferecer um ambiente favorável ao desenvolvimento de projetos de investimento de empresas estrangeiras. O propósito deste artigo é justamente investigar como a celebração desses tratados de investimento influenciou o ingresso de IED na América Latina entre 2003 e 2018. A estratégia empírica se baseia na estimação de um modelo gravitacional com dados em painel para o IED na região. Os dados utilizados se referem apenas ao greenfield investment originado de 94 países e destinado a 39 setores de atividade econômica distintos de 23 países da América Latina.

A despeito dos argumentos teóricos sugerindo que os acordos de investimento teriam efeitos positivos no ingresso de IED, ${ }^{3}$ a literatura empírica sobre o tema indica que os TBIs não necessariamente impactam positivamente sobre o IED como destaca Hallward-Driemeier (2003). Concomitantemente às incertezas sobre os efeitos positivos do TBI sobre o IED, esses tipos de acordo têm sofrido severas críticas em razão da interferência na soberania reguladora doméstica que os países em desenvolvimento

2. 0 Brasil ratificou seu primeiro acordo de investimento em 2017, apesar de já ter assinado vários deles com países como França, Alemanha, Itália e Dinamarca nos anos 1990.

3. A literatura teórica sobre a relação entre TBIs e IED é discutida no artigo Tratados bilaterais de investimento: conceitos, potenciais impactos e tendências futuras, publicado neste volume. 
aceitam ao assinar TBIs e, por seguinte, se submeterem às cláusulas dos mecanismos de solução de controvérsias do acordo (Neumayer e Spess, 2005; Elkins, Guzman e Simmons, 2006). Além dessa submissão, os mecanismos de solução de controvérsias podem gerar riscos jurídicos e financeiros adicionais sem necessariamente elevar o ingresso de IED. Os riscos de incorrer nesses custos ocupam lugar central nas críticas aos TBIs, motivando inclusive o encerramento de vários acordos. ${ }^{4}$

Portanto, diante das incertezas sobre a responsividade do IED à assinatura de TBIs, além dos potenciais custos envolvidos, é importante confirmar se os impactos esperados sobre o IED ocorreram na regiáo. Além de investigar se os acordos de investimento tiveram influência sobre o IED, este estudo irá apontar como o ambiente regulatório de cada país impacta na atração de investimento externo. No período analisado, alguns países da América Latina, como Equador e Argentina, tiveram que responder a diversas queixas de investidores em tribunais internacionais por terem supostamente violado termos dos seus acordos de investimento. Será verificado se essas reclamaçôes de investidores tiveram alguma influência sobre o IED.

Além desta introdução, o artigo possui mais cinco seções. A seção 2 apresenta uma revisão da literatura empírica que investiga como os TBIs podem influenciar o ingresso de IED. Na seção 3 será descrita a estratégia empírica do estudo. Em seguida, na seção 4, será apresentado um panorama sobre os TBIs na região e os investimentos realizados na América Latina. Na seção 5 serão reportados e discutidos os resultados da estimação do modelo econométrico. Por fim, na seção 6, algumas conclusóes serão apresentadas.

\section{RELAÇÃO ENTRE TBIS E IED: O QUE DIZEM OS ESTUDOS EMPÍRICOS}

Além de trazer as evidências sobre a relação entre TBIs e IED, nesta seção serão discutidos estudos empíricos sobre como os mecanismos de soluçáo de controvérsias dos TBIs afetam essa relação. A relação entre a assinatura e/ou ratificação de TBIs e o ingresso de IED tem sido estudada sob diferentes perspectivas. Alguns estudos analisam o impacto sob o fluxo global de investimentos externos, diferenciando apenas se o país possui ou não acordos de investimento. Outros trabalhos diferenciam os investimentos entre originados dos países com os quais o país tem acordo e investimentos globais e também originados de países desenvolvidos e em desenvolvimento. Por fim, serão apresentadas as evidências encontradas sobre como os tratados de investimento podem estar influenciando o investimento externo conforme o setor econômico.

\subsection{Impacto do TBI sobre o IED}

Nesta subseção são apresentados estudos que tentaram evidenciar a relação entre TBI e o ingresso de IED. A maioria dos estudos é do tipo cross-country, visando, a partir de dados longitudinais de diversos países, identificar a relação causal em tela. Também foram incluídos nesta revisão estudos específicos para alguns países.

Hallward-Driemeier (2003) tem foco nos fluxos de investimentos de vinte países da Organização para a Cooperação e Desenvolvimento Econômico (OCDE) para 31 países em desenvolvimento, cobrindo o período de 1980 a 2000 e $85 \%$ dos investimentos originados nos países da OCDE

4. Segundo UNCTAD (2018), o ano de 2017 foi concluído com o menor número de novos acordos internacionais de investimento desde 1983, e pela primeira vez o número de tratados com prazo encerrado superou o número de novas conclusões de acordos de investimento. 
direcionados para os países em desenvolvimento. Mesmo considerando a presença de endogeneidade na análise, a referida autora não encontrou evidências de que o TBI tenha impacto positivo no IED. Em alguns casos, o TBI apresenta efeito negativo. A autora estudou ainda como os TBIs e a qualidade das instituiçóes locais estão relacionados. Os resultados encontrados sugerem que os TBIs têm efeito positivo quando interagem com variáveis representando as instituições locais. Ou seja, os TBIs são efetivos em atrair IED em cenários de elevada qualidade institucional e onde as instituiçóes já estejam sendo fortalecidas. Isso enfraquece a racionalidade central de alguns países menos desenvolvidos que participam desses acordos na esperança de contornar a necessidade de fortalecer os direitos de propriedade e a qualidade das instituiçóes.

Rose-Ackerman e Tobin (2005) investigaram se o ingresso de investimento estrangeiro está associado positivamente com os TBIs e se o efeito do TBI é mais evidente em países com maiores riscos para o investimento. A análise cobriu o período entre 1984 e 2000, utilizando dados de países de diversos níveis de desenvolvimento. Os autores concluem que os TBIs, por si só, parecem ter pouco impacto sobre o IED, sugerindo ainda que um país deve ter algum nível mínimo de estabilidade política antes que os TBIs tenham um efeito positivo sobre sua capacidade de atrair IED.

Egger e Pfaffermayr (2004) avaliam como acordos bilaterais de investimento podem impactar no estoque de IED. Os autores utilizaram uma amostra de 55 países entre 1959 e 1999, totalizando 4.291 observaçóes, sendo 2.789 delas refletindo relaçóes entre países membros da OCDE e 1.446 observaçóes com informaçóes sobre as relaçôes entre participantes e não participantes da OCDE. Os resultados alcançados indicam que firmar um TBI tem impacto positivo de $30 \%$ sobre o estoque de IED. Os autores ressaltam que ratificar o acordo tem impacto maior do que simplesmente assiná-lo. As vantagens de simplesmente assinar um TBI e não o ratificar seriam irrelevantes. As evidências de impacto positivo dos TBIs sobre os estoques de IED são robustas à inclusão de variáveis de infraestrutura, tributação e efeitos de participação em bloco comercial e ao uso de medidas alternativas de diferenças de dotação de fatores.

De acordo com Neumayer e Spess (2005), países em desenvolvimento que assinam mais TBIs recebem mais fluxos de IED. O efeito é robusto para vários tamanhos de amostra, especificaçóes de modelos e os fluxos de IED que são normalizados pelo fluxo total de IED para os países em desenvolvimento. $\mathrm{O}$ aumento de um desvio-padrão na variável TBI em um país em desenvolvimento aumenta o ingresso de IED entre $43,7 \%$ e $93,2 \%$ e, consequentemente, tal país aumentaria sua participaçáo no fluxo de IED em relação à entrada total nos países em desenvolvimento entre $42,0 \%$ e 104,1\%. Todavia, segundo os achados do trabalho, não há fortes evidências de que os TBIs funcionam como substitutos da qualidade institucional.

Para entender a importância dos TBIs na atração de IED na América Latina, Gallagher e Birch (2006) estimaram modelos de regressóes com efeitos fixos com dados de 24 países da regiáo entre 1980 e 2003, incluindo dados sobre tamanho de mercado, estabilidade macroeconômica e dotação de fatores. $\mathrm{O}$ estudo confirma que o tamanho do mercado, a abertura comercial e a estabilidade macroeconômica são os mais importantes determinantes do IED na região. Os autores evidenciaram que o número de TBIs que o país assinou tem impacto positivo sobre o IED. Todavia, o fato de o país ter um acordo de investimento com os Estados Unidos parece não atrair investimentos desse país. Para os países da América do Sul, apenas o tamanho do mercado é relevante para atrair os investimentos de empresas americanas. 
As evidências encontradas por Tobin e Rose-Ackerman (2011), a partir de dados cobrindo 97 países no período de 1984 a 2007, sugerem que o impacto positivo dos TBIs sobre o IED está condicionado a aspectos do ambiente político e econômico. Haveria pouco impacto direto dos TBIs sobre os fluxos de IED. Por exemplo, os resultados encontrados pelos autores indicam que à medida que o nível de risco diminui e a capacidade econômica de um país aumenta, o impacto dos TBIs sobre o IED torna-se mais forte. Ao mesmo tempo, à medida que mais países do mundo entram em TBIs, reduz-se o impacto positivo dos TBIs sobre o IED. Em todas as especificaçóes, o risco político diminuído tem um impacto positivo nos fluxos de IED. No entanto, em vez de agir como um substituto para o risco político, os resultados confirmam a hipótese de que os TBIs agem para aumentar o efeito positivo sobre o IED do país com baixo risco. Especificamente, para cada ponto que um país melhora na escala de risco político considerada no artigo, o impacto de um TBI adicional resulta num aumento de $1,1 \%$ nos fluxos de IED.

Pradhan (2011), analisando as decisões de investimentos de empresas da Índia e da China, mostrou que as empresas indianas dão preferência para países com os quais a Índia tem acordos de investimentos. Não foram encontradas evidências de que as empresas chinesas guiem suas decisóes de investimento com base na existência de acordos de investimentos. O estudo de Bae e Keum (2013) mostra que os TBIs aparentam ter um pequeno efeito sobre investimentos da Coreia do Sul no exterior, mas náo têm efeito sobre influxo de investimentos no país. Os autores evidenciaram que acordos comerciais estimulam tanto o ingresso como a realização de investimentos estrangeiros na Coreia do Sul.

Egger e Merlo (2012) estudaram os efeitos dos TBIs na atuação de multinacionais alemãs no exterior. Os autores realizaram o estudo a partir de microdados de empresas. Isso permitiu levar em conta aspectos dos investimentos de multinacionais no exterior, o que os estudos feitos com dados agregados não conseguem. Segundo a análise, a ratificação dos TBIs eleva o número de empresas no país anfitrião médio em 26 unidades. Ademais, a celebração de um TBI tem o potencial de reduzir os custos fixos de investimento no país anfitriáo típico em cerca de $€ 3,7$ milhôes. O IED gerado pela assinatura e ratificação de um TBI é de cerca de $€ 5$ milhóes por empresa e, portanto, $€ 130$ milhôes por país de acolhimento, em média.

A partir de uma amostra de 125 países em desenvolvimento (excluindo a China) e países da OCDE, cobrindo o período entre 1971 e 2006, Lee e Jhonston (2016) estudaram se os TBIs de países em desenvolvimento assinados com países mais ricos têm efeito positivo não apenas no IED do país fonte signatário mas também no IED vindo de outros países. O trabalho revelou que os TBIs ajudam a atrair IED somente quando são assinados com países mais poderosos e ricos. Ademais, os TBIs atraem investimentos de outros países que não os signatários do tratado. Segundo os autores, a teoria anteriormente apresentada é corroborada, uma vez que as evidências encontradas sugerem que a assinatura de TBIs aumenta a reputação do país signatário porque os investidores estrangeiros atualizam suas crenças na proteção legal ao investimento externo em um país em desenvolvimento depois que ele participa de um TBI com um país influente.

Falvey e Foster-Mcgregor (2017) investigaram se os efeitos dos TBIs sobre o IED são não lineares. Os TBIs são assinados entre pares de países altamente heterogêneos, com diferenças importantes em termos de tamanho da economia e nível de desenvolvimento - produto interno bruto (PIB) per capita -, e o interesse do estudo foi saber se algumas dessas diferenças sistemáticas ajudam a explicar os resultados mistos dos efeitos dos TBIs sobre os fluxos de IED. Na análise realizada foi utilizada uma 
amostra de 22 países da OCDE como países de origem do IED e uma amostra de 101 economias hospedeiras menos desenvolvidas. Os autores encontraram evidências de que os impactos do TBI sobre o IED são mais fortes à medida que aumentam as diferenças entre PIB e PIB per capita entre os países fonte e destino do IED.

\subsection{Mecanismos de solução de controvérsias e seus efeitos no IED}

Em teoria, a segurança jurídica para o investidor externo propiciada pelos mecanismos de soluçáo de controvérsias ajuda a explicar parte do impacto do TBI sobre o IED. A literatura relata diferentes formatos para esses mecanismos jurídicos, alguns sendo mais rigorosos do que outros em favor do investidor em eventuais disputas investidor-Estado. Apesar da evidente importância de se conhecer como esse canal de transmissão do efeito do TBI sobre o IED opera, poucos trabalhos se debruçaram sobre essa especificidade. A seguir, serão apresentados os trabalhos relevantes que foram publicados sobre esse tema.

Em Berger et al. (2011) tem-se a primeira tentativa de observar como os diferentes mecanismos de solução de controvérsias presentes nos TBIs podem impactar o IED. Em alguns TBIs esses mecanismos são praticamente ausentes e em outros apresentam cláusulas mais estritas, que regulamentam os compromissos mútuos assumidos entre as partes. Em seu estudo empírico, os autores utilizaram médias de três anos de fluxos de IED a partir de quatorze países fonte para 83 países em desenvolvimento receptores durante o período 1978-2004. Os autores incluíram variáveis dummy indicando se o TBI possui mecanismo de solução de disputas entre investidor e Estado (Investor-State Dispute Settlement - ISDS) e cláusulas de pré-consentimento.

Inicialmente constatou-se que os países com TBIs aprestam maiores fluxos de IED, e esse efeito positivo do TBI sobre o IED é atribuído à presença de ISDS. A presença de cláusulas mais rígidas no TBI, porém, não apresentou impacto estatisticamente significativo no IED. Os autores detectaram que esse resultado é sensível à composição da amostra de países. Quando se excluem os países do Leste Europeu, o TBI e a presença de ISDS não influenciam mais o IED. Isso ocorre devido à ausência de reputação em relaçáo ao tratamento dado ao IED após a mudança de regime econômico desses países. A simples ratificação de um TBI já estimularia o ingresso de investimentos externos nos países daquela regiáo.

Por fim, o trabalho sugere que os TBIs podem ser mais relevantes para empresas de pequeno porte que desempenharam um papel importante para os fluxos de IED para os países do Leste Europeu, em comparação com as grandes multinacionais que muitas vezes celebram contratos diretos e personalizados com os governos dos países anfitrióes.

Em artigo recente, Frenkel e Walter (2019) investigaram como as diferentes provisóes de mecanismos de solução de controvérsias podem afetar os impactos dos TBIs no IED. Os autores inovaram ao criar um índice para cada TBI baseado no tipo de instrumento de soluçâo de disputa do acordo.

Em seu modelo econométrico, o IED seria determinado pela presença dos TBIs e pelo índice criado, além dos controles tradicionais. Os resultados encontrados mostram que tanto o ingresso como o estoque de IED não são influenciados pela quantidade de TBIs. O índice criado tem efeito positivo e estatisticamente significante, sugerindo que países com TBIs com especificaçôes mais rigorosas nos instrumentos de soluçáo de controvérsias têm maiores ingressos de IED. 
Quando os autores estimam seu modelo apenas para os países em desenvolvimento, encontra-se um efeito positivo tanto do número de TBIs como no índice que mede o rigor dos instrumentos de solução de controvérsias. Utilizando o método dos momentos generalizados para corrigir a provável endogeneidade no modelo, os autores encontraram resultado similar para a amostra de países em desenvolvimento. No estudo ainda foi constatado um aumento do impacto da força do acordo, mensurado pelo rigor de suas previsóes legais, sobre o IED à medida que o número de TBIs aumenta. O rigor do TBI tem impacto expressivo nos fluxos bilaterais entre as partes, principalmente quando uma das partes é um país em desenvolvimento.

Allee e Peinhardt (2010) testaram se o efeito positivo dos TBIs sobre o IED é condicionado ao comportamento do país receptor do investimento ao longo do acordo. Para esses autores, quando são acionados em fóruns internacionais de arbitragem, tal como o Centro Internacional para Arbitragem de Disputas sobre Investimentos (International Centre for Settlement of Investment Disputes ICSID), os países receptores perdem a credibilidade conquistada por meio da assinatura do TBI, desencorajando novos investidores a direcionar seus recursos para o país.

Os autores utilizaram dados de uma grande amostra de países, cobrindo o período entre 1984 e 2007. As evidências encontradas dão suporte para a relação positiva entre o número de TBIs e o ingresso de IED. No entanto, os governos que foram acionados no ICSID por violar os compromissos assumidos experimentam quedas elevadas no investimento estrangeiro. Governos que eventualmente perdem disputas do ICSID experimentam perdas ainda maiores no ingresso de IED. Ou seja, o ganho efetivo de credibilidade com o TBI é alcançado seguindo-se o compromisso assumido no acordo. $\mathrm{O}$ trabalho ainda indica que governos que são respondentes únicos no ICSID conseguem recuperar os patamares anteriores de IED entre três e cinco anos. No longo prazo, portanto, os benefícios de assinar um TBI superariam as perdas sofridas.

Num trabalho similar ao citado anteriormente, Aisbett, Busse e Nunnenkamp (2018) estudaram como um país em desenvolvimento membro do TBI ser acionado em tribunal de arbitragem impacta o ingresso de IED nesse país. Uma importante hipótese testada nesse trabalho foi a de que os TBIs têm um papel dissuasivo nos países em desenvolvimento, em razão da ameaça de uma disputa entre investidor e Estado e nos consequentes custos envolvidos nessa disputa.

As evidências encontradas pelos autores indicam que a participação no TBI estimula os fluxos bilaterais de IED, mas apenas enquanto o país em desenvolvimento anfitrião não tiver uma queixa num tribunal de arbitragem. Em outras palavras, se o país receptor do investimento for acionado por algum país em razão de um suposto não cumprimento dos termos do TBI, outros países inferirão que a ameaça de uma disputa de TBI não é um impedimento suficientemente forte para dissuadir aquele país em particular de descumprir os termos do TBI. Ademais, esse impacto negativo das reclamaçôes sobre os fluxos de IED para os países em desenvolvimento aumenta com o número de reclamaçôes apresentadas em um determinado ano contra o país anfitrião. Esse resultado é robusto em diferentes composiçóes de amostra e controle para endogeneidade.

\subsection{TBI e IED por setores}

Parte da necessidade de ratificar um TBI se deve ao problema de inconsistência dinâmica provocado pela presença de custos irrecuperáveis nos investimentos. Colen, Persyn e Guariso (2016) foi o único trabalho encontrado que estudou se os investimentos que possuem custos irrecuperáveis estão 
positivamente correlacionados a existência de TBIs. O artigo representa a primeira tentativa de estudar empiricamente o efeito heterogêneo que os TBIs podem ter em diferentes tipos de investimentos. Nele, os autores argumentam que os TBIs seriam mais eficazes nos setores da economia caracterizados por grandes custos irrecuperáveis.

O estudo foi conduzido a partir de uma amostra de dados de IED setoriais desagregados para treze países em transição da Europa Central e Oriental e da antiga União Soviética. As evidências indicam que os TBIs têm impacto positivo e náo desprezível sobre o IED. O fato de um país fazer parte de algum TBI faz o estoque de IED aumentar cerca de $1 \%$ a $2 \%$.

Os TBIs parecem ser mais bem sucedidos em atrair investimentos estrangeiros em serviços de utilidade pública, que possuem um elevado grau de irreversibilidade. Houve efeitos positivos, mas em menor magnitude, nos setores bancário e de construção civil, enquanto nenhum efeito do TBI foi encontrado para investimentos nos setores industrial e de serviços. Essas diferenças de resultados seriam explicadas pelas diferenças no grau de irreversibilidade dos investimentos entre os setores. Em outras palavras, os TBIs parecem ter relação positiva com investimentos com elevado grau de irreversibilidade.

\section{ESTRATÉGIA EMPÍRICA}

\subsection{Modelo econométrico}

Para alcançar os objetivos propostos neste estudo, será estimado um modelo gravitacional para IED na América Latina. Assim, para explicar o comércio entre países, o modelo gravitacional para IED pressupóe que o fluxo de IED do país $i$ para o país $j$ depende de variáveis que tornam mais provável a existência desse fluxo, tal como os tamanhos das duas economias e a distância entre elas. As teorias sobre IED sugerem ainda que ele estaria relacionado com outras variáveis dos países de destino, tais como o contexto institucional (Daude e Stein, 2007), a dotação e custos dos fatores de produção, as economias de aglomeração e incentivos oferecidos pelo governo local às empresas estrangeiras (Faeth, 2009). Dessa forma, o modelo empírico para os determinantes IED a ser estimado neste estudo segue o formato da equação (1).

$$
\begin{aligned}
I E D_{i j t}= & \beta_{0}+\beta_{1}\left(P I B_{i t} \cdot P I B_{j t}\right)+\beta_{2} G R W_{j t}+ \\
& \delta \cdot D T B I_{i j t}+\sum_{k=3}^{n} \beta_{k} X_{k j t}+\alpha_{i}+\gamma_{j}+\vartheta_{t}+\omega_{i j}+u_{i j t} .
\end{aligned}
$$

Em que IED é uma variável representando o valor de IED do país $i$ (país de origem do IED) para o país $j$ (destino do IED) na América Latina. Assim como em Mistura e Roulet (2019), Head e Ries (2008) e Bénassy-Quéré, Coupet e Mayer (2007), o IED na equação 1 será representado pelo estoque nominal de IED que o país $i$ investiu no país $j$. O ingresso de IED representado pelo estoque é menos volátil do que o fluxo anual, principalmente para países pequenos. Ademais, como destaca Bénassy-Quéré, Coupet e Mayer (2007), o estoque de IED representa melhor a decisão de investimento do que o fluxo anual. $\mathrm{O}$ efeito do TBI sobre o IED será estimado incluindo uma variável dummy $D T B I_{i j t}$ que é igual a 1 se o país $i$ tem um TBI vigente com o país $j$ no ano $t$, e zero caso contrário. Os demais regressores tentam levar em conta as variáveis com as quais o IED está relacionado, tais 
como as chamadas variáveis gravitacionais representadas pelos tamanhos das economias de origem e de destino do IED, mensurados pelo PIB real de cada país, e a taxa de crescimento do PIB no país de destino $\left(G R W_{j t}\right)$. No vetor $X$, estão incluídos n regressores do país de destino do IED, que tradicionalmente compóem as equaçóes de investimento, tais como a taxa bilateral de câmbio e o grau de abertura comercial.

Com relação ao efeito da taxa de câmbio sobre o IED, enquanto uma apreciação da moeda do país de origem da empresa reduz o custo do investimento no exterior, o retorno do investimento também diminui na moeda de origem. Consequentemente, a taxa de câmbio tem pouco efeito sobre a decisão de IED. Pode-se argumentar também que a desvalorização da taxa de câmbio do país de destino do IED atrai investimentos externos em razão da consequente redução do custo de capital para a empresa estrangeira, que possui acesso a meios de financiamento de menor custo para investir quando comparado com as empresas do país de destino do IED, o qual enfrenta a desvalorizaçáo cambial (Blonigen, 1997).

Helpman (2006) argumenta que as decisôes de IED e de comércio internacional são tomadas em conjunto. Para uma empresa estrangeira, é preferível produzir em países com restriçóes importantes para fazer comércio do que exportar para esses países. Apesar de haver custos fixos para a introduzir a nova planta, a empresa náo incorreria em elevados custos para realizar comércio com esse país (Helpman, 1984).Esses países seriam mais propensos a receber projetos de integração horizontal.

Já países que apresentam mais facilidade para realizar comércio, seriam mais propensos a receber projetos de integração vertical, que comporiam a rede de fornecedores da multinacional e/ou serviriam de plataforma de exportaçáo de insumos para cadeias produtivas de outras empresas.

Segundo Nicoletti et al. (2003), Fournier (2015) e Mistura e Roulet (2019), variáveis que indiquem similaridade entre os países de origem e destino do IED em aspectos como tamanho e dotação de fatores poderiam representar a maior predisposição do país de receber projetos horizontais ou verticais de IED.

Neste estudo será utilizado o indicador de similaridade do tamanho das economias de destino e origem do IED adotado por Nicoletti et al. (2003), Fournier (2015) e Mistura e Roulet (2019) (ver equação 2). Segundo Nicoletti et al. (2003), a similaridade de tamanho dos países de origem e destino contribui para IED horizontal, pois a similaridade entres as partes favorece a exploração de economias de escala no nível da empresa para projetos horizontais de IED.

$$
S I M_{i j, t}=\ln \left[1-\left(\frac{P I B_{i, t}}{P I B_{i, t}+P I B_{j, t}}\right)^{2}-\left(\frac{P I B_{j, t}}{P I B_{i, t-1}+P I B_{j, t}}\right)^{2}\right]
$$

Indicadores de dissimilaridades de fatores de produção serão calculados conforme as equaçôes (3) e (4), seguindo Nicolleti et al. (2003), Fournier (2015) e Mistura e Roulet (2019).

$\mathrm{Na}$ equação (3), representa-se as diferenças na relação capital trabalho $(K / L)$ entre os países de origem e destino do IED. Na equação 4, mede-se as diferenças nas dotaçôes de capital humano $(\mathrm{CH})$ entre os países de origem e destino do IED. Segundo Yeaple (2003) a abundância de trabalho qualificado é um fator chave para um país receber IED, assim como as diferenças de dotação de fatores entre os países de origem e destino do IED. Uma maior dissimilaridade de fatores de produção 
entre países pode afastar o IED das empresas de elevada produtividade, que são as mais propensas a realizar investimentos externos em projetos de integração horizontal, como destaca Helpman, Melitz e Yeaple (2004). Quando se buscam fatores de produção de menor produtividade para atuar em etapas do processo de produção (integração vertical), a dissimilaridade pode, no entanto, atrair IED (Fournier, 2015).

$$
\begin{aligned}
& F D_{i j, t}=\left|\ln \left(\frac{K_{i, t}}{L_{i, t}}\right)-\ln \left(\frac{K_{j, t}}{L_{j, t}}\right)\right| \\
& C H D_{i j, t}=\left|\ln \left(C H_{i, t}\right)-\ln \left(C H_{j, t}\right)\right|
\end{aligned}
$$

Neste estudo, será considerado que as diferenças entre as taxas internas de retorno dos países de origem e destino podem explicar os fluxos de IED. Essas diferenças seráo representadas pela medida de dissimilaridade entre as taxas internas de retorno do capital entre os países, calculada por meio da equação (5), em que TIR representa a taxa interna de retorno do capital. Essa variável pode ser relevante porque a decisão de investimento envolve a comparação entre a $T I R$ do capital e o seu custo. ${ }^{5} \mathrm{O}$ projeto é economicamente viável se a TIR supera o custo do capital. Dessa forma, investiga-se se as empresas multinacionais preferem investir em países com taxa interna de retorno e custo do capital semelhantes às observadas nos seus países de origem.

$$
T I R D_{i j, t}=\left|\ln \left(T I R_{i, t}\right)-\ln \left(T I R_{j, t}\right)\right|
$$

A dotação de recursos naturais nos países de destino do IED pode explicar a decisão de investir nesse país, e os países da América Latina, como Chile e Brasil, têm forte presença na extração e no comércio de recursos naturais. Em razáo disso, foi incluída no modelo uma variável que representa a extração de recursos naturais.

Na equação (1) foi incluída também uma variável que indica a qualidade regulatória do país de destino do IED. Segundo o Banco Mundial, ${ }^{6}$ a qualidade regulatória captura percepçóes da capacidade do governo de formular e implementar políticas e regulamentos sólidos que permitam e promovam o desenvolvimento do setor privado. Essa variável faz parte do rol de indicadores que representam a qualidade institucional de um país, que tem importante papel na atração de IED. Assim como as evidências empíricas já apontam (Daude e Stein, 2007; Rammal e Zurbruegg, 2006), espera-se que essa variável também seja relevante para explicar o ingresso de IED na América Latina.

Um aspecto relevante a ser explorado neste artigo é a repercussão sobre o IED quando umas das partes do acordo de investimento sofre alguma reclamaçáo de um ou mais investidores por supostamente ter infringido algum termo do acordo. Os estudos de Allee e Peinhardt (2011) e Aisbett, Busse e Nunnenkamp (2018) evidenciaram uma redução no IED quando o país receptor do investimento for acionado por algum investidor em razão de um suposto não cumprimento dos termos do TBI.

5. Segundo destacam Barrell e Pain (1996), o custo do capital é um determinante importante para os fluxos de IED.

6. Ver World Governance Indicators (WGI). Disponível em: <https:// info.worldbank.org/governance/wgi/>. 
Segundo Aisbett, Busse e Nunnenkamp (2018), em razão desse suposto descumprimento dos termos do acordo, outros países inferirão que a ameaça de uma disputa de TBI não é um impedimento suficientemente forte para dissuadir aquele país em particular de não cumprir os termos do TBI. Será incluída na equaçáo (1) uma variável dummy igual a um se o país $j$ possui um TBI ratificado com o país $i$ e ao mesmo tempo o país $j$ recebeu alguma reclamação de alguma empresa do país $i$ num certo ano t. Será avaliado também de que forma esse impacto muda com a quantidade de reclamaçóes recebidas.

Na estimação da equação (1), conforme sugerido por Egger e Pfaffermayr (2003), serão levados em conta efeitos fixos dos países de origem do IED $\left(\alpha_{i}\right)$, dos países de destino $\left(\gamma_{j}\right)$, dos pares de países $\left(\omega_{i j}\right)$ e efeitos fixos de tempo $\left(\vartheta_{t}\right)$. Os efeitos fixos dos países levam em conta a possibilidade de que variáveis omitidas observáveis e não observáveis de cada país e invariantes no tempo poderiam explicar a decisão de realizar o IED. O efeito fixo de tempo captura possíveis mudanças no ciclo econômico que afetou todos os países simultaneamente. Por fim, considerando o efeito fixo dos pares, os resultados da estimativa dos parâmetros da equação (1) não são afetados por fatores fixos no tempo característicos dos pares de países, tais como ter o mesmo idioma, fazer fronteira, distância e estar na mesma área de livre comércio.

Em uma segunda etapa desta análise, a equação (1) será estimada considerando-se a existência de efeitos fixos setoriais para os países de origem e destino do IED. Esses efeitos fixos têm o potencial de capturar aspectos setoriais observáveis e não observáveis invariáveis no tempo para os dois grupos de países, por exemplo, o fato da estrutura econômica do país de origem/destino tornar mais provável realizar/receber investimentos externos em determinado setor. Na sequência da análise, a equação (1) será estimada com variável de interação entre as variáveis dummy setoriais e a dummy indicando se o país tem acordo de investimento com o país de origem. Dessa forma, será explorado se os TBIs e o IED estão correlacionados de maneira distinta conforme o setor de destino do IED.

A estimação do modelo gravitacional, tanto para estudar fluxos comerciais quanto de investimentos, envolve a linearização por meio da aplicação de uma transformação logarítmica, e um problema recorrente nessa estimação é a presença de zeros na variável dependente. No contexto deste artigo, esses zeros ocorrem quando um país não recebe investimentos de outro país. As soluçóes encontradas na literatura, quando explicitadas, recorrem à simples exclusão dos dados com zero ou a substituição do zero por um pequeno valor que permita a aplicação da transformação logarítmica.

Excluir os zeros do modelo gravitacional faz como que o modelo seja estimado apenas entre os países que recebem investimento, gerando um problema de viés de seleção, pois esses países seriam os mais propensos a receber IED (Helpman, Melitz e Yeaple, 2004). Substituir os zeros do modelo por um valor pequeno pode distorcer a distribuição da variável dependente expressa em logaritmo, pois a transformação logarítmica diminui a dispersão dos dados, expandindo os valores mais baixos e reduzindo os mais elevados. Alternativamente, Falvey e McGregor (2017) aplicam sobre dados de IED a transformação inversa do seno hiperbólico, ${ }^{7}$ porém, para valores pequenos de $y$, essa transformação não reproduz a escala logarítmica. Como sugere Bellemare e Wichman (2019), com dados apresentando muitos zeros, é desejável modelar o processo de geração dos dados explicitamente.

Umas das opçôes disponíveis para estimar o modelo gravitacional sem descartar ou manipular as observaçóes com zeros é usar o método Poisson Pseudo Maximum Likelihood (PPML), conforme recomendam Silva e Tenreyro (2006). Os modelos PPML ao mesmo tempo são robustos na presença

7. A transformação inversa do seno hiperbólico é definida como: $\tilde{y}=\ln (y+\sqrt{y+1})$. 
de heterocedasticidade e modelam os zeros observados nos fluxos de IED. ${ }^{8}$ Por esse motivo, essa abordagem econométrica será utilizada neste artigo.

$\mathrm{Na}$ estimação da equação (1), utilizando PPML, os erros-padrões estão agrupados (clusterizados) conforme os pares de países, porque, nesse tipo de análise, pode haver uma alta persistência do nível do estoque de IED dentro de cada par de países ao longo do tempo, conforme sugere Fournier (2015). Por motivos semelhantes, na versão da equação (1) com efeitos fixos setoriais, os erros padrôes serão agrupados por setor e pares de países. No quadro 1 pode-se observar as variáveis independentes e os sinais esperados para os parâmetros estimados.

\section{QUADRO 1}

Relação de variáveis e sinal esperado para o parâmetro a ser estimado

\begin{tabular}{|l|l|}
\hline \multicolumn{1}{|c|}{ Variável independente } & \multicolumn{1}{c|}{ Sinal esperado para o parâmetro estimado } \\
\hline PIB dos países de origem e destino & Positivo \\
\hline Crescimento do PIB do país de destino & Positivo \\
\hline TBI ratificado & Positivo \\
\hline Taxa bilateral de câmbio & Neutro/positivo \\
\hline Grau de abertura comercial & Negativo/positivo \\
\hline Qualidade regulatória & Positivo \\
\hline Similaridade econômica & Positivo/negativo \\
\hline Dotação de fatores & Positivo/negativo \\
\hline Número de reclamações em tribunais internacionais & Negativo \\
\hline
\end{tabular}

Elaboração do autor.

\subsection{Fontes de dados}

A fonte de dados para o IED é o FDIMarkets, uma plataforma de dados privada que disponibiliza os fluxos anuais bilaterais de IED entre diversos países do mundo. O IED que consta nessa base de dados representa os chamados greenfield investments, ou o IED destinado à abertura de novas empresas ou expansão de atividades já existentes. A plataforma FDIMarkets monitora o IED desde 2003 e permite desagregar os dados até o nível de empresa.

Neste estudo, serão utilizados dados agregados por setores de atividade econômica, devido à dificuldade de construir um banco de dados em painel para empresas. O banco de dados disponível para esta análise contém informaçóes sobre IED originados de 94 países, destinados a 39 setores de 24 países da América Latina, entre 2003 e 2019. No anexo deste estudo, apresenta-se a relação dos países de origem e destino e setores. $\mathrm{Na}$ análise setorial dos efeitos dos TBIs sobre o IED, os setores foram agrupados em três grupos: indústria, serviços e exploração de recursos naturais. No anexo, serão apresentados os setores que compóem esses agrupamentos.

As informaçôes sobre os TBIs (Estados-partes dos acordos e anos de ratificação e conclusão) estão disponíveis no site mantido pela Conferência das Naçóes Unidas para Comércio e Desenvolvimento (United Nations Conference on Trade and Development - UNCTAD), que monitora as políticas de investimento ao redor do mundo.?

8. Silva e Tenreyro (2006) destacam que, na presença de heterocedasticidade, os erros também transformados serão correlacionados com as covariadas, resultando em estimadores inconsistentes para os parâmetros do modelo gravitacional, mesmo considerando a presença de efeitos fixos dos países de origem e destino dos investimentos.

9. Disponível em: <https://investmentpolicy.unctad.org/>. 
Com base nesses dados, foi possível construir a variável dummy $D T B I_{i j}$. Foi possível ainda definir que essa variável náo é invariante no tempo, uma vez que ela passa a ser igual a zero a partir do ano em que o TBI é encerrado.

No mesmo site é possível obter informações sobre os processos abertos por investidores para solução de controvérsias no âmbito dos TBIs. A variável dummy indicando se o país recebeu alguma reclamação foi construída a partir dessas informaçóes, assim como o número de reclamaçóes que o país recebeu. Os dados sobre PIB dos países de origem e de destino do IED, taxa de crescimento do PIB, PIB per capita, taxa de câmbio e grau de abertura comercial foram obtidos no World Development Indicators (WDI) do Banco Mundial. Dados sobre estoque de capital, índice de capital humano, número de trabalhadores e taxa interna de retorno foram coletados na Penn-World Table. O indicador de qualidade regulatória foi obtido no Word Governance Indicators (WGI) do Banco Mundial. A taxa de inflação nos países de destino do IED foi obtida no World Economic Outlook do Fundo Monetário Internacional (FMI). Os dados para a variável que representa o estoque de recursos naturais do país de destino do IED foram extraídos do WDI. Essa variável foi construída agregando-se os lucros de petróleo, gás natural, carvão, mineração e extrativismo florestal, em percentual do PIB.

A variável de crescimento econômico utilizada foi uma média móvel da taxa de crescimento real do PIB do país de destino do IED nos últimos cinco anos. As demais variáveis independentes que irão compor a equação (1) foram defasadas em um período para reduzir a possibilidade de endogeneidade na estimação. Após combinar esses dados em uma única base, o período de análise ficou restrito a 2003-2017 devido à inexistência de alguns dados para 2018. A tabela 1 apresenta estatísticas descritivas das variáveis utilizadas na estimação da equação (1).

\section{TABELA 1}

\section{Estatísticas descritivas das variáveis da equação (1)}

\begin{tabular}{|c|c|c|c|c|}
\hline Variável & Média & Desvio-padrão & Mínimo & Máximo \\
\hline Estoque de IED & 193,52 & 981,17 & 0,00 & $40.000,00$ \\
\hline$P I B_{i} \times P I B_{j}$ & 26,77 & 2,14 & 15,88 & 31,68 \\
\hline Taxa de crescimento do PIB & 1,11 & 0,72 & $-2,94$ & 2,35 \\
\hline PIB per capita & 9,35 & 0,44 & 7,37 & 10,37 \\
\hline TBI (dummy) & 0,40 & 0,49 & 0,00 & 1,00 \\
\hline Grau de abertura comercial & 3,67 & 0,52 & 2,44 & 4,79 \\
\hline Taxa de câmbio & 1,80 & 5,19 & $-25,82$ & 8,73 \\
\hline Similaridade econômica & $-1,86$ & 1,29 & $-9,61$ & $-0,69$ \\
\hline Dissimilaridade de capital humano & 0,27 & 0,19 & 0,00 & 1,13 \\
\hline Dissimilaridade de dotação de fatores & 1,16 & 0,59 & 0,00 & 3,78 \\
\hline Dissimilaridade de TIR & 0,66 & 0,43 & 0,00 & 3,19 \\
\hline Recursos naturais & 1,21 & 1,07 & $-2,87$ & 3,45 \\
\hline Qualidade regulatória & 0,11 & 0,62 & $-1,63$ & 1,54 \\
\hline Respondeu por reclamação em tribunal internacional (dummy) & 0,18 & 0,38 & 0,00 & 1,00 \\
\hline
\end{tabular}

Elaboração do autor. 


\section{VISÃO GERAL DOS DADOS}

\subsection{TBls na América Latina}

No gráfico 1 são apresentados dados sobre a evolução do número de acordos de investimentos ratificados na América Latina da década de 1960 até os dias atuais. Assim como no resto do mundo (UNCTAD, 2018), durante os anos 1990 houve um expressivo aumento no número de TBIs ratificados pelos países da América Latina. Em 2019, a região acumulou mais de 400 TBIs ratificados. O gráfico 1 mostra também que, até o início dos anos 1990, os parceiros nesses acordos eram exclusivamente países de renda elevada, ${ }^{10}$ um fato esperado dado o propósito inicial dos TBIs, que era proteger os investimentos dos países desenvolvidos em nações ainda em desenvolvimento. Todavia, a partir de meados da década de 1990, os países da América Latina passaram a ter parceiros de renda média e baixa. Em 2019 cerca de um terço dos acordos são com esses países. Essa tendência ocorreu em concomitância com a adoção de políticas de liberalização do comércio adotadas na região, que, segundo Perea e Stephenson (2018), foram importantes responsáveis pelo aumento de IED originados em países em desenvolvimento. Ao passarem a ser exportadores de capital, mesmo em menor medida que os países desenvolvidos, é possível que os países da América Latina passem a procurar também proteção para os investimentos realizados pelas suas empresas multinacionais por meio de acordos de investimento com países em desenvolvimento.

\section{GRÁFICO 1}

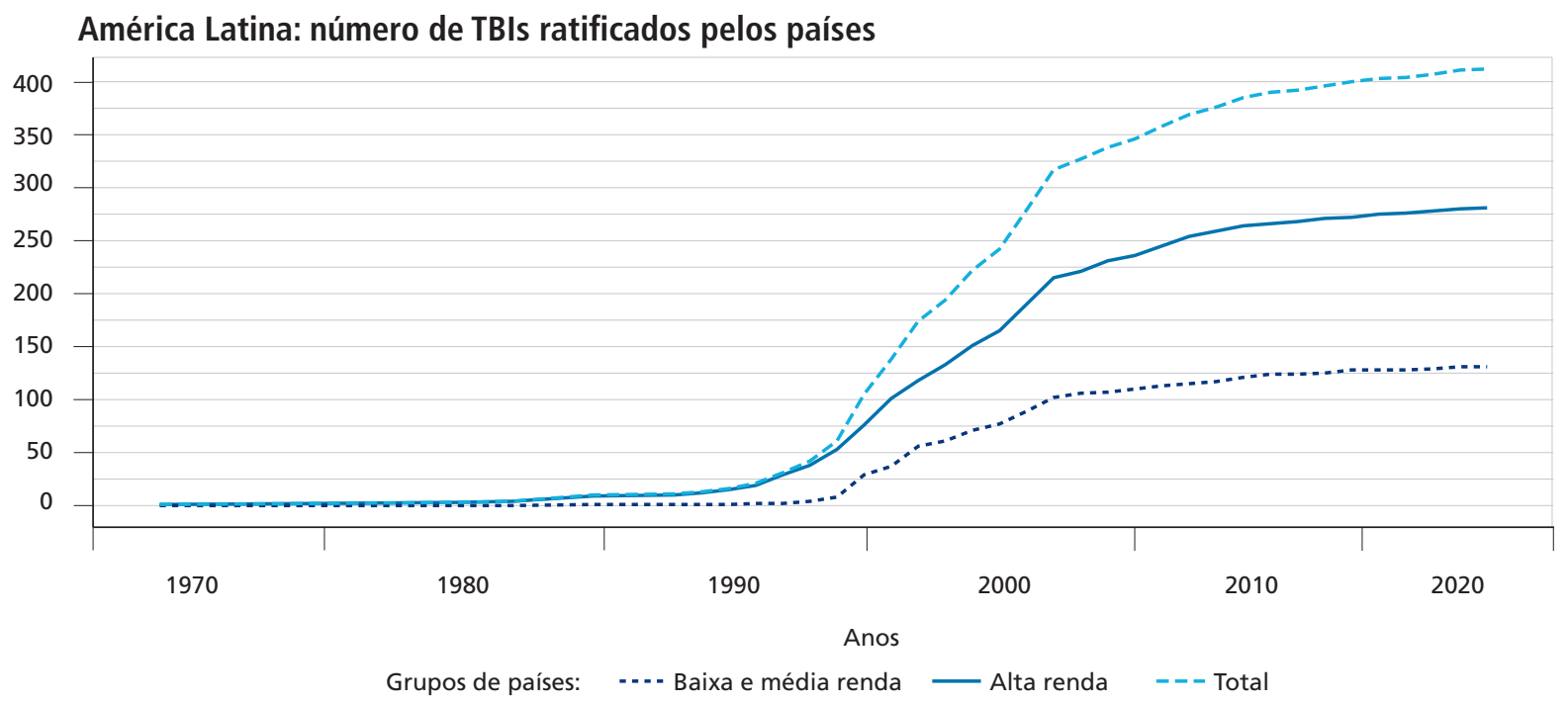

Fonte: UNCTAD.

Elaboração do autor.

Um breve histórico sobre os TBIs ratificados por países da América Latina pode ser observado na tabela 2. O primeiro país a ratificar um TBI foi a Costa Rica, no ano de 1966, tendo como parceiro a Suíça. Poucos anos depois, o Equador ratificou seu primeiro acordo, também com a Suíça. Como já indicado no gráfico 1, a maior parte dos países começou a ratificar seus TBIs a partir da década de 1990. Ao longo das últimas décadas, Argentina e Chile foram os países que ratificaram mais TBIs. 
Os dados ainda indicam que a maior parte dos parceiros nesses acordos é composta por países ricos. A Argentina foge desse padrão, pois possui vários acordos com países de renda média - onze de seus parceiros são países da própria América Latina. Dos 22 acordos que o Brasil assinou desde a década de 1990 , apenas um foi ratificado. ${ }^{11}$

TABELA 2

América Latina: sumário dos TBls ratificados

\begin{tabular}{|c|c|c|c|c|c|}
\hline País & Data do primeiro TBI & Total de TBIs ratificados & TBIs com países de renda elevada & TBls encerrados & Total de reclamações \\
\hline Argentina & 1992 & 54 & 25 & 6 & 61 \\
\hline Barbados & 1993 & 9 & 5 & 0 & 0 \\
\hline Belize & 1982 & 5 & 4 & 0 & 3 \\
\hline Bolívia & 1990 & 22 & 15 & 12 & 17 \\
\hline Brasil & 2017 & 1 & 0 & 0 & 0 \\
\hline Chile & 1994 & 41 & 23 & 5 & 5 \\
\hline Colômbia & 2007 & 9 & 4 & 3 & 13 \\
\hline Costa Rica & 1966 & 16 & 11 & 1 & 10 \\
\hline República Dominicana & 1996 & 12 & 9 & 1 & 0 \\
\hline Equador & 1969 & 27 & 14 & 24 & 23 \\
\hline El Salvador & 1992 & 19 & 14 & 2 & 3 \\
\hline Granada & 1988 & 2 & 2 & 0 & 0 \\
\hline Guatemala & 2001 & 18 & 16 & 1 & 5 \\
\hline Haiti & 1975 & 3 & 3 & 0 & 0 \\
\hline Honduras & 1994 & 9 & 9 & 0 & 2 \\
\hline México & 1996 & 32 & 27 & 2 & 34 \\
\hline Nicarágua & 1995 & 14 & 12 & 1 & 2 \\
\hline Panamá & 1985 & 20 & 16 & 1 & 10 \\
\hline Paraguai & 1980 & 22 & 14 & 1 & 3 \\
\hline Peru & 1991 & 32 & 21 & 3 & 16 \\
\hline Uruguai & 1985 & 30 & 21 & 1 & 5 \\
\hline Venezuela & 1993 & 27 & 16 & 2 & 60 \\
\hline
\end{tabular}

Fonte: UNCTAD.

Elaboração do autor.

Os dados da tabela 2 mostram ainda que, nos últimos anos, determinados países não renovaram alguns de seus TBIs, notadamente a Bolívia e o Equador - este encerrou 24 dos seus 27 TBIs ratificados.

Esse fenômeno não ocorreu apenas na América Latina. A Índia, por exemplo, encerrou mais de setenta dos seus acordos de investimento nos últimos anos. Segundo UNCTAD (2018), em 2017 o número de acordos encerrados superou o número de acordos ratificados pela primeira vez. Um dos motivos para o encerramento de TBIs é o crescente número de reclamaçôes de investidores em tribunais internacionais. De acordo com dados da UNCTAD, ${ }^{12}$ dos países da América Latina elencados na tabela 2, apenas seis não receberam alguma reclamação formal. Das 257 reclamaçóes recebidas por países da América Latina, em 19,5\% a decisão foi dada a favor do Estado e em 25,6\% a favor da

11. Cabe salientar que o Brasil possui um modelo de acordo de investimentos diferente, chamado de Acordo de Cooperação e Facilitação de Investimentos (ACFI), já assinado com diversos países, mas ratificado apenas com Angola e México.

12. Dados disponíveis em: <https://investmentpolicy.unctad.org/investment-dispute-settlement>. 
empresa reclamante. ${ }^{13} \mathrm{~A}$ Argentina foi o país da região que mais enfrentou litígios, principalmente entre 2001 e 2005, época de elevada instabilidade macroeconômica do país. Ao mesmo tempo em que encerrou quase todos os seus acordos de investimento, o Equador também teve que responder a um número considerável de reclamaçóes e, em sete, o tribunal decidiu a favor do investidor, condenando o país a pagar elevados valores aos reclamantes.

\subsection{IED greenfield na América Latina}

Os dados do FDIMarkets mostram que empresas de 96 países realizaram investimentos do tipo greenfield na América Latina entre 2003 e 2019. Segundo mostra a figura 1, que representa os estoques de IED segundo o país de origem, empresas situadas nos Estados Unidos são as maiores investidoras na regiáo, seguido das empresas da Espanha e do Canadá. Aparentemente, os montantes de IEDs originados desses países são explicados pelas variáveis gravitacionais - ou que naturalmente tornam mais provável a existência de fluxos de investimento entre os países, tais como proximidade e o tamanho dessas economias -, além do idioma comum e do histórico colonial, no caso da Espanha. Nota-se também que entre os países da América Latina, o Brasil é o que mais investe na região. No continente asiático, China e Japão são os maiores parceiros nas relações de investimento com a América Latina.

\section{FIGURA 1}

\section{América Latina: origem do estoque de IED entre 2003 e 2018}
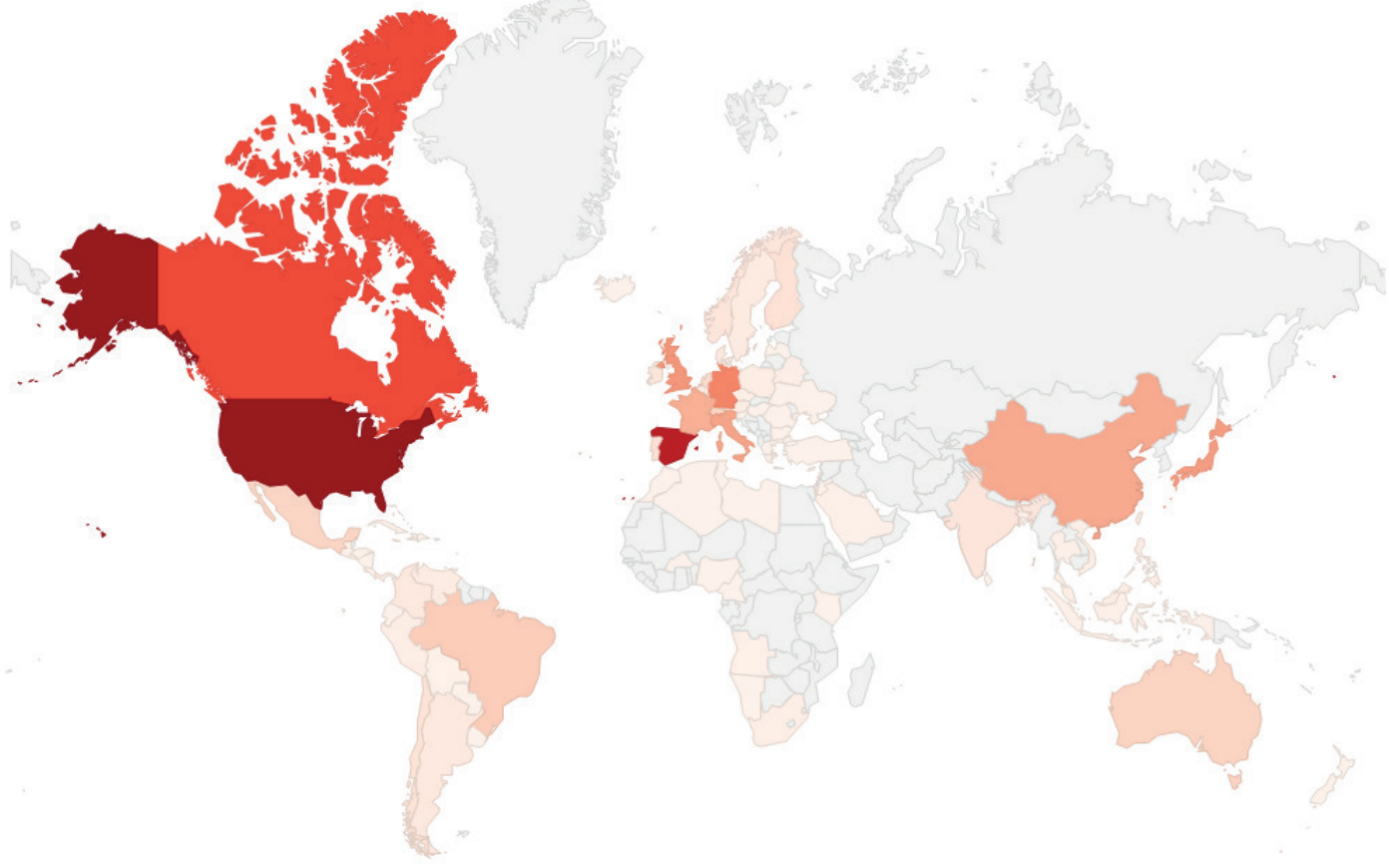

0,075 175.000

Fonte: FDIMarkets.

Elaboração do autor

13. Mais detalhes sobre os outros possíveis resultados para o julgamento no tribunal internacional estão disponíveis em: <https://investmentpolicy. unctad.org/investment-dispute-settlement>. 
Os países que mais acumularam IED na região no período analisado foram Brasil e México, concentrando cerca de 52\% do estoque de IED na América Latina (gráfico 2). Esses dois países em conjunto com Chile, Peru, Argentina e Colômbia detêm mais de $80 \%$ de todo o estoque de IED na América Latina. Os mesmos países concentram cerca de $73 \%$ do PIB da América Latina. Portanto, ao mesmo tempo que grandes economias são grandes emissoras de IED para a regiáo, as maiores economias latino-americanas são as que mais recebem esse tipo de investimento, indicando a existência de uma correlação entre os tamanhos das economias e os fluxos (saída e entrada) de IED.

\section{GRÁFICO 2}

\section{América Latina: destino do IED entre 2003 e 2019}

\section{(Em \%)}

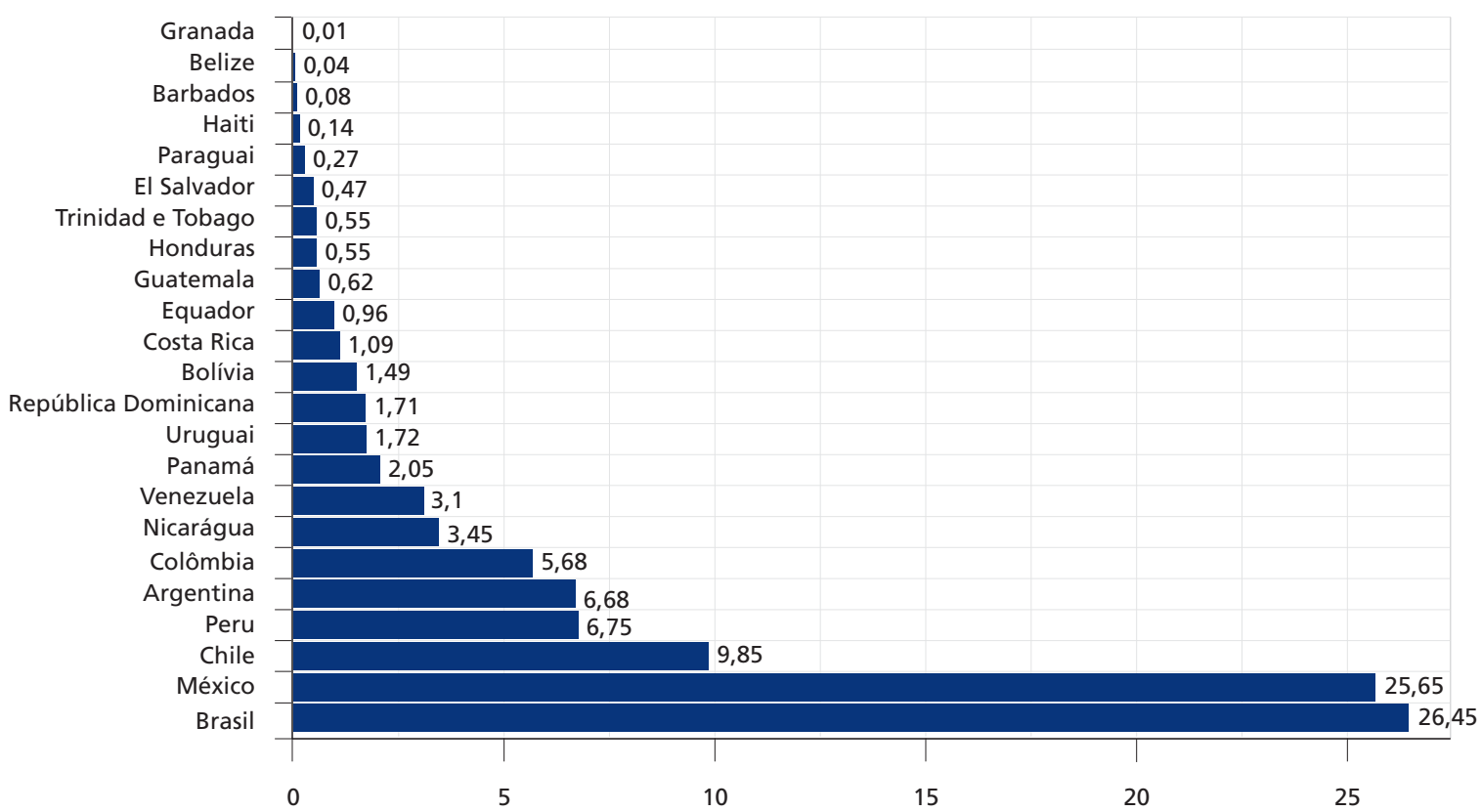

Fonte: FDIMarkets

Elaboração do autor.

Desagregado o IED na regiáo por setor de atividade econômica, obtém-se o gráfico 3. A classificação setorial adotada é a utilizada pelo FDIMarkets. As empresas do setor de metalurgia e siderurgia respondem por $16,12 \%$ de todo o IED realizado na América Latina no período em questáo, seguido dos investimentos na extração de carvão, óleo e gás, comunicaçôes, energias renováveis e no setor automotivo. Essas cinco atividades concentram 61,4\% do IED realizado na América Latina. Investimentos relacionados à extração de recursos naturais (metalurgia e siderurgia, carvão, óleo e gás e minerais) representam quase $30 \%$ de todo o IED realizado na regiáo. $\mathrm{Na}$ atividade de serviços, o setor de serviços financeiros é o que tem maior destaque, representado $4,77 \%$ do total de IED destinado à América Latina. 


\section{GRÁFICO 3}

\section{América Latina: distribuição do IED por setor de atividade econômica} (Em \%)

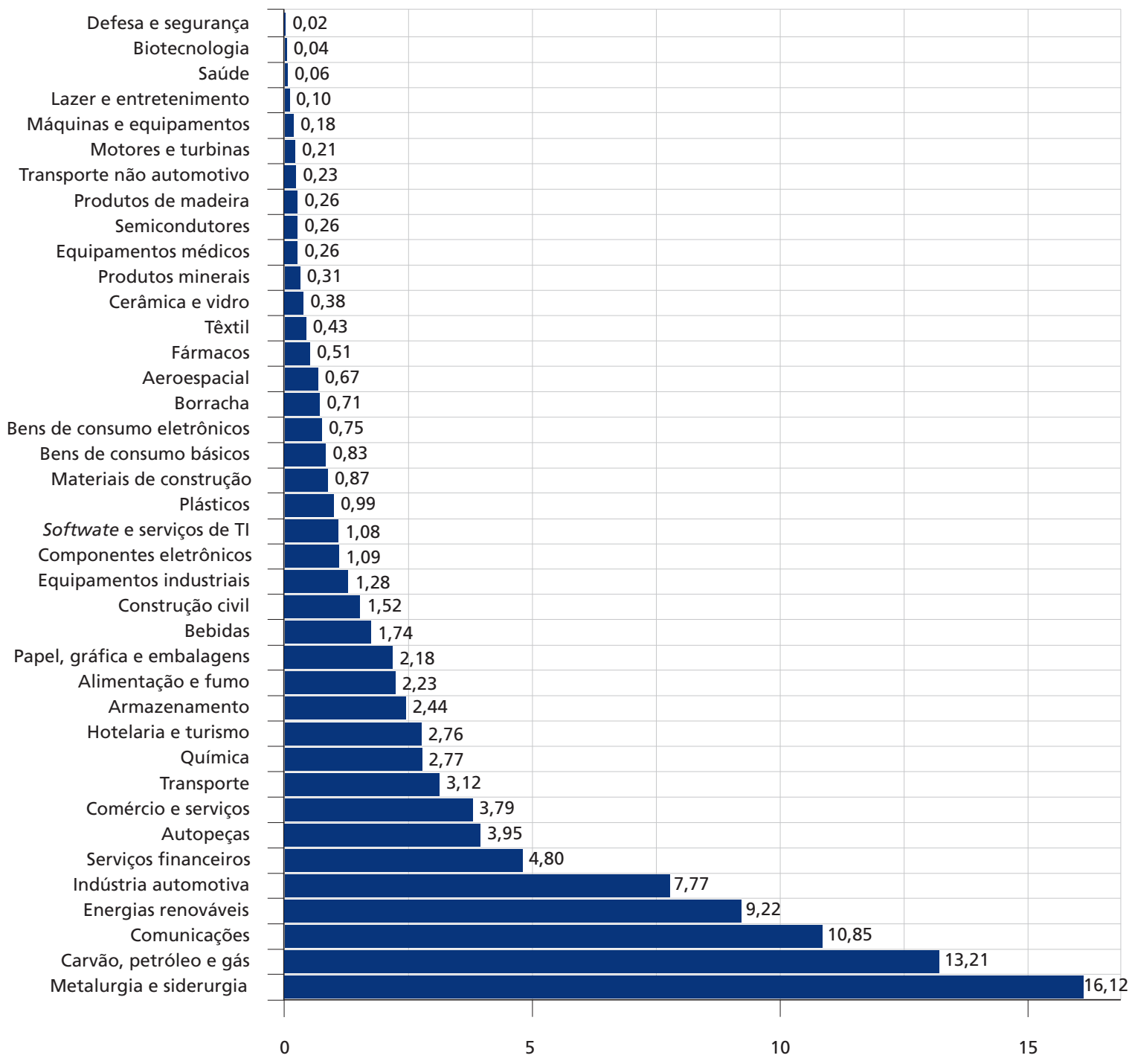

Fonte: FDIMarkets.

Elaboração do autor.

A figura 2 é um diagrama de Sankey ilustrando o fluxo de saída de IED por grupo de países para os setores e, em seguida, para os principais destinos de IED na América Latina. Para facilitar a visualização dos resultados, os setores foram agregados em três grupos, e os países de origem foram agregados conforme o continente a que pertencem. Apenas os principais destinos de IED foram exibidos na imagem.

A origem dos investimentos em setores industriais é dividida entre Europa, América do Norte e Leste Asiático. Os principais destinos dos investimentos de empresas desse segmento são Brasil e México, e a maior parcela de IED que chega nesses países é para o setor industrial, assim como na Argentina.

No setor de recursos naturais, os países europeus têm destaque próximo a Canadá e Estados Unidos em conjunto. Os principais destinos desses investimentos são Brasil, México, Chile e Peru. No Chile, Peru, Colômbia e Venezuela os investimentos são os mais relevantes na composição setorial do IED. 
FIGURA 2

Origem do estoque de IED dos principais países

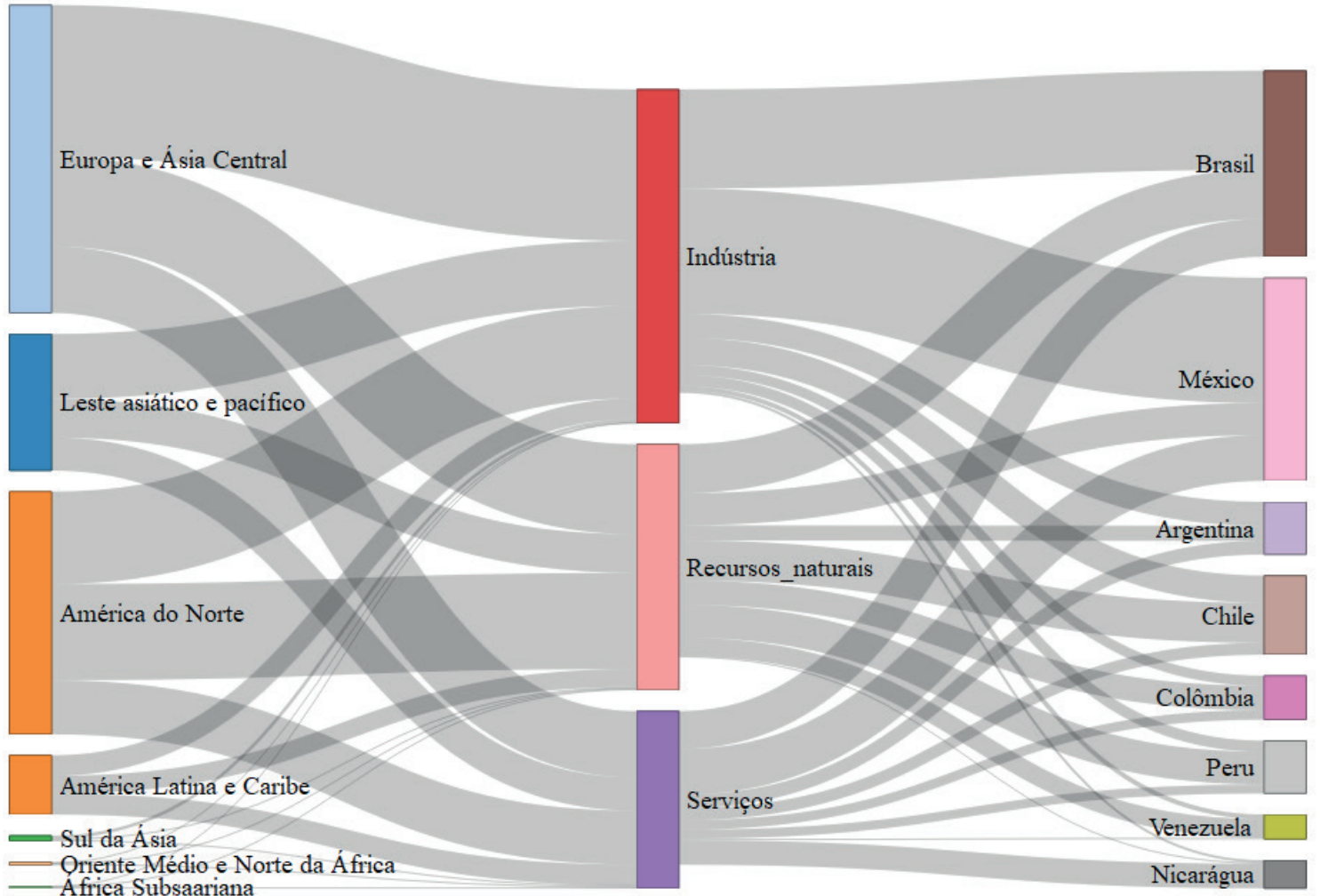

Fonte: FDIMarkets.

Elaboração do autor.

Obs.: Figura cujos leiaute e textos não puderam ser padronizados e revisados em virtude das condições técnicas dos originais (nota do Editorial).

Os investimentos no setor de serviços são originados principalmente de Europa, América do Norte e países do Leste Asiático. Os principais destinos são Brasil e México. Nota-se também que o IED na Nicarágua se origina quase que totalmente do setor de serviços. Os países da América Latina em conjunto investem menos do que os países do Leste Asiático (China e Japão inclusos). Percebe-se ainda que o IED originado na regiáo se distribui em parcelas semelhantes para os três agrupamentos de setores.

\section{EVIDÊNCIAS ECONOMÉTRICAS}

\subsection{Resultados gerais}

A tabela 3 reporta os resultados da estimação para seis versóes da equação (1), conforme a quantidade de variáveis consideradas. Inicialmente, o teste de erro de especificação de equaçáo de regressão (Regression Equation Specification Error Test - RESET) aponta que apenas os modelos 4, 5 e 6 apresentam uma especificação apropriada a $10 \%$ de significância.

A respeito dos resultados, nota-se que o parâmetro estimado para a variável dummy TBI não é estatisticamente significativo em nenhuma das especificaçóes da equaçáo (1), considerando efeitos 
fixos dos países, dos pares e de tempo. Já o efeito do crescimento real do PIB do país de destino é estatisticamente significativo a $1 \%$ em todos os modelos, indicando que a importância dessa variável para o ingresso de novos projetos de investimento nos países da região.

\section{TABELA 3}

Resultados da estimação do modelo gravitacional para IED

\begin{tabular}{|c|c|c|c|c|c|c|}
\hline \multirow{2}{*}{ Variáveis } & \multicolumn{6}{|c|}{ Modelos } \\
\hline & Modelo 1 & Modelo 2 & Modelo 3 & Modelo 4 & Modelo 5 & Modelo 6 \\
\hline$P I B_{i} \times P I B_{j}$ & $\begin{array}{c}0.0597 \\
(0.0432)\end{array}$ & $\begin{array}{c}0.0314 \\
(0.0466)\end{array}$ & $\begin{array}{c}0.0581 \\
(0.0551)\end{array}$ & $\begin{array}{l}0.0738 \\
(0.054)\end{array}$ & $\begin{array}{c}0.0735 \\
(0.0536)\end{array}$ & $\begin{array}{l}0.0934^{*} \\
(0.0556)\end{array}$ \\
\hline Taxa de crescimento do $P I B_{j}$ & $\begin{array}{c}0.0910 * * * \\
(0.0288)\end{array}$ & $\begin{array}{c}0.0911^{* * *} \\
(0.0271)\end{array}$ & $\begin{array}{c}0.0957^{* * *} \\
(0.0269)\end{array}$ & $\begin{array}{c}0.0961^{* * *} \\
(0.0262)\end{array}$ & $\begin{array}{c}0.0950^{* * *} \\
(0.0265)\end{array}$ & $\begin{array}{c}0.0738^{* * *} \\
(0.0272)\end{array}$ \\
\hline TBI (dummy) & $\begin{array}{l}-0.1027 \\
(0.2109)\end{array}$ & $\begin{array}{c}-0.1042 \\
(0.2134)\end{array}$ & $\begin{array}{l}-0.1307 \\
(0.2046)\end{array}$ & $\begin{array}{l}-0.1475 \\
(0.1824)\end{array}$ & $\begin{array}{l}-0.1571 \\
(0.1854)\end{array}$ & $\begin{array}{l}-0.2576 \\
(0.1898)\end{array}$ \\
\hline Grau de abertura comercial & & $\begin{array}{c}0.1948^{* *} \\
(0.0799)\end{array}$ & $\begin{array}{c}0.2926^{* * *} \\
(0.0898)\end{array}$ & $\begin{array}{c}0.2513^{* * *} \\
(0.0828)\end{array}$ & $\begin{array}{c}0.2296^{* * *} \\
(0.084)\end{array}$ & $\begin{array}{c}0.3170^{* * *} \\
(0.1028)\end{array}$ \\
\hline Taxa de Câmbio & & & $(0.0018)$ & $\begin{array}{c}0.0042 \\
(0.0029)\end{array}$ & $\begin{array}{c}0.0041 \\
(0.0029)\end{array}$ & $\begin{array}{l}-0.0054 \\
(0.0062)\end{array}$ \\
\hline Similaridade econômica & & & $\begin{array}{c}-0.0543 \\
(0.0343)\end{array}$ & $\begin{array}{c}-0.035 \\
(0.0309)\end{array}$ & $\begin{array}{l}-0.0311 \\
(0.031)\end{array}$ & $\begin{array}{c}-0.0283 \\
(0.0566)\end{array}$ \\
\hline Dissimilaridade de capital humano & & & $\begin{array}{c}0.2811 \\
(0.1737)\end{array}$ & $\begin{array}{l}0.2806^{*} \\
(0.1695)\end{array}$ & $\begin{array}{l}0.2796 \\
(0.171)\end{array}$ & $\begin{array}{c}0.0553 \\
(0.1575)\end{array}$ \\
\hline Dissimilaridade de dotação de fatores & & & $\begin{array}{l}-0.0052 \\
(0.0641)\end{array}$ & $\begin{array}{l}-0.0154 \\
(0.0604)\end{array}$ & $\begin{array}{l}-0.0138 \\
(0.0615)\end{array}$ & $\begin{array}{c}0.0531 \\
(0.0946)\end{array}$ \\
\hline Dissimilaridade de TIR & & & $\begin{array}{c}-0.3635^{* * *} \\
(0.1332)\end{array}$ & $\begin{array}{c}-0.3705^{* * *} \\
(0.1333)\end{array}$ & $\begin{array}{c}-0.3842^{* * *} \\
(0.1332)\end{array}$ & $\begin{array}{c}-0.5215^{* * *} \\
(0.184)\end{array}$ \\
\hline Recursos naturais & & & $\begin{array}{l}-0.0169 \\
(0.052)\end{array}$ & $\begin{array}{l}-0.0098 \\
(0.0499)\end{array}$ & $\begin{array}{l}-0.0073 \\
(0.0489)\end{array}$ & $\begin{array}{c}0.0069 \\
(0.07)\end{array}$ \\
\hline Respondeu por reclamação em tribunal internacional & & & & $\begin{array}{c}-0.3098^{* * *} \\
(0.1057)\end{array}$ & & \\
\hline Uma reclamação (dummy) & & & & & $\begin{array}{c}-0.3065^{* * *} \\
(0.1095)\end{array}$ & $\begin{array}{c}-0.3313^{* * *} \\
(0.0998)\end{array}$ \\
\hline Duas reclamações (dummy) & & & & & $\begin{array}{c}-0.3012^{* * *} \\
(0.0981)\end{array}$ & $\begin{array}{c}-0.2961^{* * *} \\
(0.0817)\end{array}$ \\
\hline Três reclamações (dummy) & & & & & $\begin{array}{c}-0.4739 * * * \\
(0.1666)\end{array}$ & $\begin{array}{c}-0.4958^{* * *} \\
(0.1469)\end{array}$ \\
\hline Quatro reclamações (dummy) & & & & & $\begin{array}{c}-0.3258^{* *} \\
(0.1343)\end{array}$ & $\begin{array}{c}-0.3159^{* *} \\
(0.1266)\end{array}$ \\
\hline Cinco reclamações (dummy) & & & & & $\begin{array}{c}-0.2875^{* *} \\
(0.13)\end{array}$ & $\begin{array}{c}-0.2790^{* *} \\
(0.1156)\end{array}$ \\
\hline Seis ou mais reclamações (dummy) & & & & & $\begin{array}{c}-0.5383^{* * *} \\
(0.1826)\end{array}$ & $\begin{array}{c}-0.5189^{* * *} \\
(0.1508)\end{array}$ \\
\hline Qualidade regulatória & & & & & & $\begin{array}{c}0.2372^{* *} \\
(0.1108)\end{array}$ \\
\hline Constante & $\begin{array}{c}7.1178^{* * *} \\
(1.2416)\end{array}$ & $\begin{array}{c}7.2123^{* * *} \\
(1.4226)\end{array}$ & $\begin{array}{c}6.2643^{* * *} \\
(1.7301)\end{array}$ & $\begin{array}{c}6.0933^{* * *} \\
(1.6984)\end{array}$ & $\begin{array}{c}6.2208^{* * *} \\
(1.6829)\end{array}$ & $\begin{array}{c}5.3929 * * * \\
(1.7499)\end{array}$ \\
\hline N & 9840 & 9840 & 8841 & 8841 & 8841 & 7333 \\
\hline Pseudo R2 & 0.967 & 0.9672 & 0.9681 & 0.9686 & 0.9688 & 0.9702 \\
\hline RESET (Prob > chi2) & 0.0016 & 0.0206 & 0.0508 & 0.4527 & 0.3711 & 0.9440 \\
\hline
\end{tabular}

Elaboração do autor.

Obs.: 1. Erro-padrão robusto entre parênteses.

2. Significância $\left({ }^{*}\right)=10 \% ;\left({ }^{* *}\right)=5 \% ;\left(^{* *}\right)=1 \%$.

O parâmetro associado ao grau de abertura comercial apresentou sinal positivo e é estatisticamente significativo a 1\% nos modelos mais completos. Conforme argumenta Helpman (1984), nesse caso, 
o grau de abertura comercial e o IED possivelmente estão relacionados em razão de projetos de integração vertical implementados na América Latina por empresas multinacionais. Ou seja, empresas estrangeiras fazem investimentos nos países latino-americanos na expectativa de complementar ou compor etapas de suas cadeias de produção, e, com isso, países em que é mais fácil realizar trocas comerciais seriam mais propensos a receber esses projetos.

A taxa bilateral de câmbio não possui efeito estatisticamente significativo sobre o IED. As variáveis que representam a similaridade entre os tamanhos das economias e as medidas de dissimilaridade de dotação de fatores de produção não aparentam influenciar o IED. Encontrou-se um resultado estatisticamente significativo a 5\% na medida de dissimilaridade de retorno do capital. Ou seja, em países em que as taxas internas de retorno são mais diferentes, os fluxos de IED são menores. Isso confirma a hipótese levantada de que empresas multinacionais buscam países em que o retorno do capital seja ao menos similar ao observado no seu país de origem.

Quando a taxa interna de retorno é um critério para avaliar um projeto diante do seu custo de capital, pode-se inferir, a partir desse resultado, que as empresas buscam opçóes de investimento em outros países com custo de capital similares ao de seus países. Apesar da região receber muitos projetos de investimento relacionados à extração de recursos naturais e produção de seus derivados, o parâmetro da variável que representa a dotaçáo de recursos naturais não foi estatisticamente significativo em nenhum dos modelos estimados.

A partir do modelo 4, observa-se significância estatística de 1\% para a estimativa do parâmetro da variável dummy indicando se o país recebeu alguma reclamação de um investidor de país parceiro no TBI. No modelo 5, foram incluídas variáveis dummy indicando quantas reclamaçóes o país recebeu. Em qualquer quantidade de reclamações, observam-se efeitos negativos. Esse efeito é consideravelmente maior no caso em que o país recebeu seis ou mais reclamaçóes. Portanto, de maneira geral, responder numa corte arbitral àlguma reclamação de uma empresa contestando alguma medida do governo que vai de encontro aos termos do TBI tem efeito negativo no IED, e esse efeito aumenta à medida que mais reclamaçôes são feitas, confirmando evidências similares em Allee e Peinhardt (2010) e Aisbett, Busse e Nunnenkamp (2018). Muito provavelmente, esse efeito negativo pode ser atribuído à perda de credibilidade que o país experimenta ao ser contestado em algum tribunal internacional.

Por fim, no modelo 6 é explorado o papel da qualidade regulatória nos fluxos de IED. Foi evidenciado que a variável de qualidade regulatória é positivamente relacionada com o IED. Esse resultado corrobora os estudos de Daude e Stein (2007) e sugere que países da América Latina recebem maiores volumes de IED quando leis e regulamentos são aplicados em favor do desenvolvimento empresarial.

\subsection{Resultados setoriais}

Os resultados da estimação da equação (1) considerando os efeitos fixos relacionados aos setores estão reportados na tabela 4. Nota-se que a inclusão de efeitos fixos setoriais não alterou substancialmente os resultados apresentados anteriormente. De acordo com os parâmetros estimados, a ratificação de acordos de investimento náo resultou em aumento no recebimento de mais investimento externo. O tamanho das economias que recebem e que originam o IED, porém, tem relevância na definição do ingresso de IED, e os países da América Latina que apresentam maiores taxas de crescimento tendem a receber mais investimento greenfield. Países com maiores correntes de comércio apresentam 
maiores ingressos de IED, provavelmente, como discutido anteriormente, direcionados para projetos de integração vertical.

As empresas também buscam países com taxas de retorno do capital semelhante ao observado em seus países de origem, conforme indica o resultado para a variável de dissimilaridade da taxa interna de retorno do capital. A qualidade regulatória tem efeito positivo e estatisticamente significativo sobre o IED, e o fato de o país de destino ter sofrido alguma reclamação num tribunal de arbitragem faz o IED ser menor do que para os países que náo foram denunciados por violar termos de acordo de investimento. $\mathrm{O}$ fato de o país ter recebido queixas de investidores tem efeito negativo sobre o IED, e esse efeito aumenta com o número de reclamaçóes. Quem recebe seis ou mais reclamaçóes tem importantes perdas de investimento externo.

As variáveis de interação entre as variáveis dummy de setor e de TBI não são estatisticamente significativas em nenhum dos agrupamentos considerados. Efeitos setoriais do TBI sobre IED seriam plausíveis na presença de custos irrecuperáveis intrínsecos de projetos em setores específicos e que demandariam a segurança jurídica de um acordo de investimento. A presença desses custos irrecuperáveis, no entanto, pode ser um efeito fixo setorial invariável no tempo, muitas vezes não observável corretamente, e que foi eliminado no processo de estimação do modelo. Acredita-se que, por esses argumentos, os investimentos nesses setores náo se tornam maiores quando o país tem um acordo de investimento ratificado.

TABELA 4

Resultados da estimação do modelo gravitacional para IED considerando efeitos fixos setoriais

\begin{tabular}{|c|c|c|c|c|}
\hline \multirow{2}{*}{ Variáveis } & \multicolumn{4}{|c|}{ Modelos } \\
\hline & Modelo 1 & Indústria & Serviços & Recursos naturais \\
\hline$P I B_{i} \times P I B_{j}$ & $\begin{array}{l}0.0947^{*} \\
(0.0539)\end{array}$ & $\begin{array}{l}0.0945^{*} \\
(0.0539)\end{array}$ & $\begin{array}{l}0.0945^{*} \\
(0.0539)\end{array}$ & $\begin{array}{l}0.0948^{*} \\
(0.0538)\end{array}$ \\
\hline Taxa de crescimento do PIBj & $\begin{array}{c}0.0747^{* * *} \\
(0.0278)\end{array}$ & $\begin{array}{c}0.0744^{* * *} \\
(0.0278)\end{array}$ & $\begin{array}{c}0.0748^{* * *} \\
(0.0278)\end{array}$ & $\begin{array}{c}0.0745^{* * *} \\
(0.0278)\end{array}$ \\
\hline TBI (dummy) & $\begin{array}{c}-0.2631 \\
(0.1859)\end{array}$ & $\begin{array}{l}-0.2795 \\
(0.1956)\end{array}$ & $\begin{array}{l}-0.2541 \\
(0.2019)\end{array}$ & $\begin{array}{l}-0.2392 \\
(0.1808)\end{array}$ \\
\hline Grau de abertura comercial & $\begin{array}{c}0.3190^{* * *} \\
(0.0985)\end{array}$ & $\begin{array}{c}0.3189^{* * *} \\
(0.0985)\end{array}$ & $\begin{array}{c}0.3200^{* * *} \\
(0.0991)\end{array}$ & $\begin{array}{c}0.3181^{* * *} \\
(0.0989)\end{array}$ \\
\hline Taxa de Câmbio & $\begin{array}{c}-0.006 \\
(0.0063)\end{array}$ & $\begin{array}{c}-0.006 \\
(0.0063)\end{array}$ & $\begin{array}{c}-0.006 \\
(0.0063)\end{array}$ & $\begin{array}{c}-0.006 \\
(0.0063)\end{array}$ \\
\hline Similaridade econômica & $\begin{array}{c}-0.0272 \\
(0.0573)\end{array}$ & $\begin{array}{l}-0.0268 \\
(0.0572)\end{array}$ & $\begin{array}{c}-0.0275 \\
(0.0573)\end{array}$ & $\begin{array}{l}-0.0267 \\
(0.0571)\end{array}$ \\
\hline Dissimilaridade de capital humano & $\begin{array}{c}0.0508 \\
(0.1497)\end{array}$ & $\begin{array}{c}0.0505 \\
(0.1495)\end{array}$ & $\begin{array}{c}0.0507 \\
(0.1497)\end{array}$ & $\begin{array}{c}0.0506 \\
(0.1496)\end{array}$ \\
\hline Dissimilaridade de dotação de fatores & $\begin{array}{c}0.0506 \\
(0.0948)\end{array}$ & $\begin{array}{c}0.0507 \\
(0.0947)\end{array}$ & $\begin{array}{c}0.0509 \\
(0.0948)\end{array}$ & $\begin{array}{c}0.0503 \\
(0.0947)\end{array}$ \\
\hline Dissimilaridade de TIR & $\begin{array}{c}-0.5225^{* * *} \\
(0.1876)\end{array}$ & $\begin{array}{c}-0.5221^{* * *} \\
(0.1876)\end{array}$ & $\begin{array}{c}-0.5233^{* * *} \\
(0.1876)\end{array}$ & $\begin{array}{c}-0.5216^{* * *} \\
(0.1876)\end{array}$ \\
\hline Qualidade regulatória & $\begin{array}{c}0.2415^{* *} \\
(0.1118)\end{array}$ & $\begin{array}{c}0.2424^{* *} \\
(0.1113)\end{array}$ & $\begin{array}{c}0.2408^{* *} \\
(0.1115)\end{array}$ & $\begin{array}{c}0.2426^{* *} \\
(0.1104)\end{array}$ \\
\hline Recursos naturais & $\begin{array}{c}0.006 \\
(0.0703)\end{array}$ & $\begin{array}{c}0.0063 \\
(0.0702)\end{array}$ & $\begin{array}{c}0.0057 \\
(0.0703)\end{array}$ & $\begin{array}{c}0.0064 \\
(0.0701)\end{array}$ \\
\hline Uma reclamação (dummy) & $\begin{array}{c}-0.3304^{* * *} \\
(0.0944)\end{array}$ & $\begin{array}{c}-0.3293^{* * *} \\
(0.0936)\end{array}$ & $\begin{array}{c}-0.3313^{* * *} \\
(0.0941)\end{array}$ & $\begin{array}{c}-0.3291^{* * *} \\
(0.0926)\end{array}$ \\
\hline Duas reclamações (dummy) & $\begin{array}{c}-0.2944^{* *} \\
(0.1193)\end{array}$ & $\begin{array}{c}-0.2943^{* *} \\
(0.1194)\end{array}$ & $\begin{array}{c}-0.2922^{* *} \\
(0.1197)\end{array}$ & $\begin{array}{c}-0.2964^{* *} \\
(0.1202)\end{array}$ \\
\hline
\end{tabular}




\begin{tabular}{|c|c|c|c|c|}
\hline \multirow{2}{*}{ Variáveis } & \multicolumn{4}{|c|}{ Modelos } \\
\hline & Modelo 1 & Indústria & Serviços & Recursos naturais \\
\hline Três reclamações (dummy) & $\begin{array}{c}-0.4943^{* * *} \\
(0.1582)\end{array}$ & $\begin{array}{c}-0.4952^{* * *} \\
(0.1583)\end{array}$ & $\begin{array}{c}-0.4909^{* * *} \\
(0.159)\end{array}$ & $\begin{array}{c}-0.4979^{* * *} \\
(0.1586)\end{array}$ \\
\hline Quatro reclamações (dummy) & $\begin{array}{l}-0.3106 \\
(0.1895)\end{array}$ & $\begin{array}{c}-0.3110^{*} \\
(0.1871)\end{array}$ & $\begin{array}{r}-0.3043 \\
(0.192)\end{array}$ & $\begin{array}{c}-0.3166^{*} \\
(0.1878)\end{array}$ \\
\hline Cinco reclamações (dummy) & $\begin{array}{l}-0.2741 \\
(0.1689)\end{array}$ & $\begin{array}{l}-0.2743 \\
(0.1672)\end{array}$ & $\begin{array}{l}-0.2688 \\
(0.1709)\end{array}$ & $\begin{array}{c}-0.2790^{*} \\
(0.1685)\end{array}$ \\
\hline Seis ou mais reclamações (dummy) & $\begin{array}{c}-0.5137^{* *} \\
(0.2025)\end{array}$ & $\begin{array}{c}-0.5140^{* *} \\
(0.2015)\end{array}$ & $\begin{array}{c}-0.5089^{* *} \\
(0.204)\end{array}$ & $\begin{array}{c}-0.5183^{* *} \\
(0.2031)\end{array}$ \\
\hline TBI x Indústria & & $\begin{array}{c}0.0838 \\
(0.2062)\end{array}$ & & \\
\hline TBI x Serviç̧os & & & $\begin{array}{c}-0.0432 \\
(0.1626)\end{array}$ & \\
\hline TBI x Recursos naturais & & & & $\begin{array}{c}-0.0401 \\
(0.23)\end{array}$ \\
\hline Constante & $3.6962^{* *}$ & $3.6987^{* *}$ & $3.6985^{* *}$ & $3.6953^{* *}$ \\
\hline N & 39969 & 39969 & 39969 & 39969 \\
\hline Pseudo R2 & 0.884 & 0.884 & 0.884 & 0.884 \\
\hline
\end{tabular}

Elaboração do autor.

Obs.:1. Erro-padrão robusto entre parênteses.

2. Significância $\left({ }^{*}\right)=10 \% ;\left({ }^{* *}\right)=5 \% ;\left({ }^{* *}\right)=1 \%$.

\section{CONSIDERAÇÕES FINAIS}

Tendo em vista a maior segurança que os tratados bilaterais de investimento propiciam aos investidores externos, espera-se que esses acordos favoreçam os fluxos de investimento principalmente para os países em desenvolvimento. Para os países da América Latina, marcados por cenários institucionais bem mais instáveis do que nos países ricos, é igualmente esperado que os acordos de investimento firmados elevem o ingresso de IED.

Todavia, segundo este estudo, não ficou evidenciada uma relação entre o ingresso de investimentos greenfiled e a ratificaçáo de acordos de investimento. Em outras palavras, controlando para as variáveis consideradas no modelo estimado e diversos efeitos fixos, há países atraindo vultosos projetos de investimentos de empresas de outros países mesmo sem haver acordos de investimento entre os dois países, como é o caso da economia brasileira.

Com base no modelo gravitacional estimado, foram encontradas evidências de que o crescimento econômico dos países de destino é relevante para a atração do investimento, assim como o grau de abertura comercial. Observou-se, ainda, que as empresas multinacionais aparentam querer investir em países que apresentam taxa de retorno do capital semelhante à observada em seus países. Nesse sentido, os resultados encontrados reforçam o argumento em favor de melhorias institucionais nos países da América Latina.

Celebrar um TBI, entretanto, pode reduzir o ingresso de IED, caso o país de destino seja denunciado por algum investidor que se sentiu prejudicado diante de alguma conduta do governo do país de destino. Nessa hipótese, além de incorrer nos custos associados à sua defesa no tribunal internacional, o país ainda pode se tornar menos atrativo para novos projetos em razão da perda de credibilidade resultante da reclamação recebida. 
A análise setorial confirmou o importante papel desempenhado pelo crescimento econômico e pelo grau de abertura das economias para atrair investimentos para a regiáo. Mesmo considerando efeitos fixos setoriais, o efeito da qualidade regulatória foi positivo e estatisticamente significativo. No mesmo conjunto de estimaçóes, foram confirmados os efeitos negativos resultantes de receber reclamaçôes por violar os termos dos acordos de investimento.

Mesmo diante desses resultados, acredita-se que, ao reduzir os riscos do investimento, estabelecendo regras claras de indenização para o investidor no caso se expropriação e também por servir de canal de comunicação entre os governos dos países de origem e de destino na questáo dos investimentos externos, os acordos de investimento podem ser úteis.

Por fim, são desejáveis mudanças recentes nos formatos dos acordos de investimento, sendo mais bem definido o que deve ser considerado como expropriação indireta e também em relação aos termos que garantam o direito de regular e criar um bom ambiente de investimentos, sem perder o direito de criar regulaçóes que permitam perseguir objetivos de desenvolvimento sustentável e outros de natureza socioeconômica. Essas mudanças podem evitar muitas das reclamaçôes de investidores que geram perdas importantes no ingresso de IED em países em desenvolvimento como os da América Latina.

\section{REFERÊNCIAS}

AISBETT, E.; BUSSE, M.; NUNNENKAMP, P. Bilateral investment treaties as deterrents of host-country discretion: the impact of investor-state disputes on foreign direct investment in developing countries. Review of World Economics, v. 154, n. 1, p. 119-155, 2018.

ALLEE, Todd; PEINHARDT, Clint. Delegating differences: Bilateral investment treaties and bargaining over dispute resolution provisions. International Studies Quarterly, v. 54, n. 1, p. 1-26, 2010.

BAE, C.; KEUM, H. The impact of free trade agreements on foreign direct investment: the case of Korea. East Asian Economic Review, v. 17, n. 4, 2013. p. 417-444.

BARRELL, R.; PAIN, N. An econometric analysis of US foreign direct investment. The review of economics and statistics, v. 78, n. 2, p. 200-207, 1996.

BELLEMARE, M. F.; WICHMAN, C. J. Elasticities and the inverse hyperbolic sine transformation. Oxford Bulletin of Economics and Statistics. Oxford, United States: University of Oxford and John Wiley \& Sons Ltd, 2019.

BÉNASSY-QUÉRÉ, A.; COUPET, M.; MAYER, T. Institutional determinants of foreign direct investment. World economy, v. 30, n. 5, p. 764-782, 2007.

BERGER, A. et al. More stringent BITs, less ambiguous effects on FDI? Not a BIT! Economics Letters, v. 112, n. 3, p. 270-272, 2011.

BLONIGEN, B. Firm-specific assets and the link between exchange rates and foreign direct investment. American Economic Review, v. 87, n. 3, p. 447-65, 1997.

COLEN, L.; PERSYN, D.; GUARISO, A. Bilateral Investment Treaties and FDI: Does the Sector Matter? World Development, v. 83, p. 193-206, 2016.

DAUDE, C.; STEIN, E. The quality of institutions and foreign direct investment. Economics \& Politics, v. 19, n. 3, p. 317-344, 2007.

EGGER, P.; MERLO, V. BITs bite: An anatomy of the impact of bilateral investment treaties on multinational firms. The Scandinavian Journal of Economics, v. 114, n. 4, p. 1240-1266, 2012. 
EGGER, P.; PFAFFERMAYR, M. The proper panel econometric specification of the gravity equation: A three-way model with bilateral interaction effects. Empirical Economics, v. 28, n. 3, p. 571-580, 2003.

The impact of bilateral investment treaties on foreign direct investment. Journal of comparative economics, v. 32, n. 4, p. 788-804, 2004.

ELKINS, Z.; GUZMAN, A. T.; SIMMONS, B. A. Competing for capital: the diffusion of bilateral investment treaties, 1960-2000. International Organization, v. 60, n. 4, p. 811-846, 2006.

FAETH, I. Determinants of foreign direct investment - A tale of nine theoretical models. Journal of Economic Surveys, v. 23, n. 1, p.165-196, 2009.

FALVEY, R.; FOSTER-MCGREGOR, N. Heterogeneous effects of bilateral investment treaties. Review of World Economics, v. 153, n. 4, p. 631-656, 2017.

FRENKEL, M.; WALTER, B. Do bilateral investment treaties attract foreign direct investment? The role of international dispute settlement provisions. The World Economy, v. 42, n. 5, p. 1316-1342, 2019.

FOURNIER, J.-M. The negative effect of regulatory divergence on foreign direct investment, OECD Economics Department Working Papers, n. 1268. Paris: OECD Publishing, 2015.

GALLAGHER, K. P.; BIRCH, M. B. L. Do investment agreements attract investment? Evidence from Latin America. Journal of World Investment and Trade, v. 7, n. 6, p. 961-974, 2006.

GUZMAN, A. T. Explaining the popularity of bilateral investment treaties. In: SAUVANT, K. P.; SACHS, L. E. (Eds.) The effect of treaties in foreign direct investment: bilateral investment treaties, double taxation treaties, and investment flows. Oxford; New York: Oxford University Press, p. 73-98, 2009.

HALLWARD-DRIEMEIER, M. Do bilateral investment treaties attract foreign direct investment? Only a BIT... and they could bite. Washington, D. C.: World Bank Group, 2003. (Policy Research Working Paper Series, n. 3121).

HEAD, K.; RIES, J. C. FDI as an outcome of the market for corporate control: theory and evidence. Journal of International Economics, v. 74, n. 1, 2-20, 2008.

HELPMAN, E. A simple theory of international trade with multinational corporations. Journal of political economy, v. 92, n. 3, p. 451-471, 1984.

HELPMAN, E. Trade, FDI, and the Organization of Firms. Journal of economic literature, v. 44, n. 3, p. 589-630, 2006.

HELPMAN, E.; MELITZ, M. J.; YEAPLE, S. R. Export versus FDI with heterogeneous firms. American Economic Review, v. 94, n. 1, p. 300-316, 2004.

KERNER, A. Why should I believe you? the costs and consequences of bilateral investment treaties. International Studies Quarterly, v. 53, n. 1, p. 73-102, 2009.

KOHLER, W.; STÄHLER, F. The economics of investor protection: ISDS versus national treatment, Munich: CESifo, 2016. (CESifo Working Paper, n. 5766).

LEE, C.-Y.; JOHNSTON, N. P. Improving reputation BIT by BIT: bilateral investment treaties and foreign accountability. International Interactions, v. 42, n. 3, p. 429-451, 2016.

MISTURA, F.; ROULET, C. The determinants of foreign direct investment: Do statutory restrictions matter? 2019/01, Paris: OECD Publishing, 2019. (OECD Working Papers on International Investment, v. 2019 , n. 1).

NEUMAYER, E.; SPESS, L. Do bilateral investment treaties increase foreign direct investment to developing countries? World Development, v. 33, n. 10, p. 1567-1585, 2005. 
NICOLETTI, G. et al. The influence of policies on trade and foreign direct investment. OECD Economic Studies, v. 2003, n. 1, p. 7-83, 2003.

PEREA, J. R.; STEPHENSON, M. Outward FDI from developing countries. In: THE WORLD BANK GROUP. Global Investment Competitiveness Report 2017/2018. Washington, D. C.: World Bank, 2018, p. 101-134.

PRADHAN, J. P. Emerging multinationals: a comparison of chinese and indian outward foreign direct investment. International Journal of Institutions and Economies, v. 3, n. 1, p. 113-148, 2011.

RAMMAL, H. G.; ZURBRUEGG, R. The impact of regulatory quality on intra-foreign direct investment flows in the ASEAN markets. International Business Review, v. 15, n. 4, p. 401-414, 2006.

ROSE-ACKERMAN, S.; TOBIN, J. L. Foreign direct investment and the business environment in developing countries: the impact of bilateral investment treaties. Yale Law \& Economics Research Paper, n. 293, 2005.

SILVA, J. S.; TENREYRO, S. The Log of Gravity. The Review of Economics and Statistics, v. 88, n. 4, p. 641-658, 2006.

TOBIN, J. L.; ROSE-ACKERMAN, S. When BITs have some bite: the political-economic environment for bilateral investment treaties. Review of International Organizations, v. 6, n. 1, p. 1-32, 2011.

UNCTAD - United Nations Conference on Trade and Development. Bilateral Investment Treaties. Treaties 1959-1999. New York: United Nations Publication, 2000.

IIA Issues Note: Recent developments in the international investment regime. Geneva: UNCTAD, 2018. Disponível em: <https://unctad.org/system/files/official-document/diaepcbinf2018d1_en.pdf>.

YEAPLE, S. R. The role of skill endowments in the structure of US outward foreign direct investment. Review of Economics and Statistics, v. 85, n. 3, p. 726-734, 2003. 
ANEXO

QUADRO A. 1

Agrupamento de setores

\begin{tabular}{|c|c|}
\hline \multirow{25}{*}{ Indústria } & Aeroespacial \\
\hline & Autopeças \\
\hline & Indústria automotiva \\
\hline & Bebidas \\
\hline & Biotecnologia \\
\hline & Materiais de construção \\
\hline & Máquinas e equipamentos \\
\hline & Cerâmica e vidro \\
\hline & Química \\
\hline & Bens de consumo eletrônicos \\
\hline & Bens de consumo básicos \\
\hline & Componentes eletrônicos \\
\hline & Motores e turbinas \\
\hline & Alimentação e fumo \\
\hline & Equipamentos industriais \\
\hline & Equipamentos médicos \\
\hline & Transporte não automotivo \\
\hline & Papel, gráfica e embalagens \\
\hline & Fármacos \\
\hline & Plásticos \\
\hline & Energias renováveis \\
\hline & Borracha \\
\hline & Semicondutores \\
\hline & Têxtil \\
\hline & Produtos de madeira \\
\hline & Comércio e serviços \\
\hline & Comunicações \\
\hline & Serviços financeiros \\
\hline & Saúde \\
\hline & Hotelaria e turismo \\
\hline Serviços & Lazer e entretenimento \\
\hline & Software e serviços de TI \\
\hline & Defesa e segurança \\
\hline & Transporte \\
\hline & Armazenamento \\
\hline & Serviços imobiliários \\
\hline & Carvão, petróleo e gás \\
\hline Recursos naturais & Metalurgia e siderurgia \\
\hline & Produtos minerais \\
\hline
\end{tabular}

Fonte: FDIMarkets. 
QUADRO A.2

América Latina: países que realizaram investimentos greenfield na região entre 2003 e 2019

\begin{tabular}{|c|c|c|c|c|}
\hline Argélia & Ilhas Cayman & Hong Kong & Mônaco & Eslovênia \\
\hline Andorra & Chile & Hungria & Marrocos & África do Sul \\
\hline Angola & China & Islândia & Namíbia & Espanha \\
\hline Antígua e Barbuda & Colômbia & Índia & Países Baixos & Sri Lanka \\
\hline Argentina & Costa Rica & Indonésia & Nova Zelândia & Suécia \\
\hline Aruba & Cuba & Iran & Nicarágua & Suíça \\
\hline Austrália & Chipre & Irlanda & Noruega & Síria \\
\hline Áustria & República Checa & Israel & Panamá & Tailândia \\
\hline Bahamas & Dinamarca & Itália & Paraguai & Trinidad e Tobago \\
\hline Bangladesh & República Dominicana & Jamaica & Peru & Tunísia \\
\hline Barbados & Equador & Japão & Filipinas & Turquia \\
\hline Bielorrússia & El Salvador & Quênia & Polônia & Ucrânia \\
\hline Bélgica & Finlândia & Coreia do Sul & Portugal & Reino Unido \\
\hline Bermudas & França & Kuwait & Catar & Estados Unidos \\
\hline Bolívia & Alemanha & Letônia & Romênia & Uruguai \\
\hline Brasil & Grécia & Líbano & Federação Russa & Venezuela \\
\hline Bulgária & Guatemala & Liechtenstein & Arábia Saudita & Vietnã \\
\hline Camarões & Haiti & Malta & Singapura & Cisjordânia \\
\hline Canadá & Honduras & México & República Eslovaca & \\
\hline
\end{tabular}

Fonte: FDIMarkets. 


\title{
ACORDOS DE INVESTIMENTO E A DIFUSÃO DAS IDEIAS DE RESPONSABILIDADE SOCIAL CORPORATIVA: APONTAMENTOS CRÍTICOS A PARTIR DO MODELO BRASILEIRO
}

Marina Sanches Wünsch

Fábio Costa Morosini²

\begin{abstract}
SINOPSE
Este artigo visa analisar a inserção da cláusula de responsabilidade social corporativa (RSC), enquanto instrumento de proteção de direitos humanos, nos tratados bilaterais de investimento (TBIs); e explorar se os Acordos de Cooperação e Facilitação de Investimentos (ACFIs) brasileiros oferecem avanços sobre o tema. Nesse sentido, o texto examina a difusão do movimento de RSC e sua relação com o paradigma neoliberal e expõe as lacunas existentes no atual marco regulatório sobre empresas e direitos humanos. Por fim, o estudo propõe caminhos pelos quais é possivel avançar na responsabilização das empresas transnacionais, dentro e fora dos TBls.
\end{abstract}

Palavras-chave: direitos humanos; responsabilidade social corporativa; empresas transnacionais; tratados bilaterais de investimento.

\begin{abstract}
This article intends to analyze the inclusion of corporate social responsibility (CSR) clauses, as an instrument for the protection of human rights, in bilateral investment treaties (BITs); and to explore whether the Brazilian Agreements on Investment Cooperation and Facilitation (Acordos de Cooperação e Facilitação de Investimentos - AICFs) sheds new light to the ongoing debate. Accordingly, the paper deals with the diffusion of the CSR movement and its relationship with the neoliberal paradigm and presents the gaps in the current regulatory framework on business and human rights. Finally, the paper proposes ways in which it is possible to advance for an enforceable model of accountability for transnational corporations, both inside and outside the BITs.
\end{abstract}

Keywords: human rights; corporate social responsibility; transnational corporations; bilateral investment treaties.

JEL: F21; F23; K38; M14; N4.

Artigo recebido em 8/3/2021 e aprovado em 30/3/2021.

DOl: http://dx.doi.org/10.38116/bepi29art9

\section{INTRODUÇÃO}

A responsabilidade social corporativa (RSC) de atores estrangeiros (investidores e empresas, por exemplo) tem sido um tema crítico nas últimas décadas, repercutindo nos debates sobre neoliberalismo, desenvolvimentismo e defensores de direitos humanos (DHs). Este artigo pretende discutir a inserção de cláusulas de RSC nos tratados bilaterais de investimento (TBIs) e seu papel na proteção de DHs.

1. Professora da Universidade Federal do Pampa (Unipampa); e doutora em estudos estratégicos internacionais pela Universidade Federal do Rio Grande do Sul (UFRGS), com bolsa de estudos da Coordenação de Aperfeiçoamento de Pessoal de Nível Superior (Capes). E-mail:<marinawunschs@gmail.com>.

2. Professor associado da Faculdade de Direito da UFRGS, onde coordena o Centro para Direito, Globalização e Desenvolvimento. E-mail:<fabio.morosini@ufrgs.br>. 
Além disso, pretende analisar se os Acordos de Cooperação e Facilitação de Investimentos (ACFIs) brasileiros oferecem avanços sobre o tema.

A atuação das empresas transnacionais ${ }^{3}$ (ETNs) ocorre por meio do investimento estrangeiro direto (IED) e os TBIs se popularizaram como mecanismo de regulação estatal desses investimentos. Entretanto, entre 1950 e 1990, esses tratados refletiam uma maior preocupação em proteger os investidores, uma vez que os fluxos de investimento tendiam a ser unidirecionais, no sentido Norte-Sul. Já a preocupação com a proteção dos $\mathrm{DH}$ s concentrou-se quase exclusivamente no regime internacional dos $\mathrm{DH}$, que enfrenta dificuldades para impor sua efetividade, especialmente diante das violaçóes cometidas por ETNs.

A partir dos anos 1980, com a redução do papel do Estado e diante de um processo de desregulação, houve o crescimento da influência das ETNs. Tal ambiente criou as condiçôes para um movimento de autorregulação da atuação das ETNs por meio de mecanismos de RSC. Este artigo busca evidenciar a intrínseca relaçáo entre o surgimento do movimento de RSC e o neoliberalismo, ${ }^{4}$ ainda nos anos 1980.

Atualmente, a inserção de cláusulas de RSC objetiva inserir a agenda de DHs nos TBIs. Todavia, surgem questionamentos acerca de cláusulas de proteção de $\mathrm{DHs}$ que possam ir além de mecanismos voluntários (soft law) e assegurem efetivamente a proteção dos $\mathrm{DH}$ da população impactada pelos investimentos. Tais questionamentos decorrem do contexto neoliberal em que está inserido o movimento de RSC, que sugere um processo de desregulaçáo pelo Estado e de autorregulaçáo da atuação de atores privados por meio de mecanismos voluntários.

O artigo está assim estruturado: inicialmente, busca-se contextualizar a origem da RSC e sua relação com a regulação internacional das ETNs. Em seguida, diante do avanço do movimento de RSC, analisa-se a sua inserção nos acordos de investimento tradicionais, bem como discute-se o modelo brasileiro de acordo, o ACFI, enquanto alternativa proveniente de um país em desenvolvimento. Finalmente, o artigo encaminha propostas a fim de avançar na discussão acerca das cláusulas de RSC em acordos de investimento enquanto um novo mecanismo de proteção dos DHs.

3. A expressão transnacional foi consagrada pela Organização das Nações Unidas (ONU). ETNs são definidas como empresas que atuam além e através das fronteiras estatais (em inglês, transnational corporations - TNCs). 0 termo é considerado por parte da doutrina como mais correto, porque o qualificativo "multinacional" pode conduzir a equívoco, uma vez que essas empresas não têm muitas nacionalidades. Neste artigo, a palavra multinacionais será utilizada apenas para manter a forma original usada pelo autor de referência ou o correspondente período histórico.

4. 0 neoliberalismo não é um único conceito ou modelo, porém seu marco teórico pode ser claramente identificado. A doutrina neoliberal surge em oposição às teorias do Estado intervencionista, como as de John M. Keynes, e obteve respeitabilidade acadêmica quando Friedrich Hayek, em 1974, e Milton Friedman, em 1976, ganharam o Prêmio Nobel de Economia. Ademais, passou a ter grande influência com a adoção de políticas econômicas de cunho neoliberal pelos governos Thatcher (1979), na Inglaterra, e Reagan (1980), nos Estados Unidos, entre outros. Hall (2011), em seu artigo The Neoliberal Revolution: Thatcher, Blair, Cameron - the long march of neoliberalism continues, define 0 modelo neoliberal tanto como a ausência do governo do Estado sobre os indivíduos livres e sua propriedade privada quanto como economia de livre mercado, ou seja, ausência de intervenção do Estado na economia, especialmente quanto a regulações estatais, com prevalência dos interesses corporativos e privados (op. cit., p. 10-11). 


\section{CONTEXTUALIZAÇÃO DA RSC}

\subsection{A regulação das ETNs e os DHs}

O sistema internacional de proteção aos DHs é centrado no Estado, ou seja, está baseado na obrigação dos Estados em proteger os DHs. Logo, os mecanismos de coerção e responsabilização são direcionados aos Estados como parte dos tratados internacionais sobre o tema. Ocorre que, nas últimas décadas, os Estados deixaram de ter, no plano internacional, o monopólio das acusaçóes de agente violador de $\mathrm{DH}$ s, enquanto tem crescido o número de denúncias contra ETNs por violaçóes desse tipo.

Um dos primeiros casos a atrair grande atenção internacional e a ser levado a um tribunal foi o do dramaturgo e ativista de DHs nigeriano Ken Saro-Wiwa, em $1995 .{ }^{5}$ Ele é visto como o ponto de inflexão para o desencadeamento do debate sobre empresas e DHs, que é crescente no âmbito das organizaçóes internacionais.

Cabe ressaltar, entretanto, que debates entre países hospedeiros de IED e ETNs já haviam sido travados na ONU ainda nos anos 1960 e 1970, ligados a temas como regimes de propriedade mineral e a soberania dos Estados $^{6}$ (Busturia, 2015, p. 197-198). Além da ONU, no mesmo período, outras iniciativas partiram da Organização Internacional do Trabalho (OIT), com a Declaraçáo Tripartite de Princípios sobre Empresas Multinacionais e Política Social, de 1977; e da Organização para a Cooperação e o Desenvolvimento Econômico (OCDE), com as Diretrizes para Empresas Multinacionais, de 1976, acordadas por dez países-membros como parte da Declaração sobre o Investimento Internacional e as Empresas Multinacionais.

As diretrizes da OCDE são recomendações voluntárias para as ETNs referentes a questôes como emprego, relações industriais, ética, DHs, meio ambiente, corrupçáo etc. Para Bustura (2015, p. 119-121), essas diretrizes são um marco importante do desenvolvimento e do impulsionamento da RSC e resultam da crescente pressão das ETNs na ONU para evitar a adoção de um código de conduta vinculante. Essa pressão esvaziou o espaço criado na ONU para a regulação das ETNs, transferindo o processo para outras organizaçôes internacionais mais alinhadas aos interesses empresariais.

As primeiras iniciativas de regular as ETNs ocorreram, portanto, nos anos 1970. Já entre os anos 1980 e 2000, tais iniciativas no plano internacional ficaram estagnadas. No entanto, a assinatura do Pacto Global, em 2000, marca o retorno do debate sobre a responsabilidade das empresas no âmbito da ONU.

Outro marco importante ocorreu em 2005, por meio da Resolução no 2005/1969, que criou um mandato de representante especial do secretário-geral (special representative of the secretary-general -

5. 0 chamado caso Wiwa envolveu as empresas Royal Dutch Petroleum e Shell Transport and Trading por meio de sua subsidiária Shell Petroleum Development Company (SPDC) da Nigéria, joint venture criada para a exploração e a extração de petróleo no delta do rio Níger. Ken Saro-Wiwa participava do Movimento pela Sobrevivência do Povo Ogoni (Mosop), que reivindicava a sobrevivência do povo indígena ogoni, opunha-se ao governo nigeriano e protestava ativamente contra o modo como a Shell Nigéria conduzia suas atividades na região (Martín-Ortega, 2008, p. 72-73).

6. Em 1962, países em desenvolvimento levaram à Assembleia Geral da ONU a discussão relativa à soberania dos Estados sobre seus recursos naturais. 0 resultado foi a Resolução no 1.803 da XVII Assembleia Geral, de 14 de dezembro de 1962, a respeito da "soberania permanente sobre os recursos naturais". A independência das antigas colônias na África e na Ásia e as denúncias sobre a relação das ETNs com regimes militares na América Latina também contribuíram para impulsionar o debate sobre a necessidade de regulação das ETNs no interior de organizações não governamentais (ONGs), levando, inclusive, à discussão sobre a elaboração de um código de conduta internacional em 1975 (Frieden, 2008). 
SRSG) da ONU sobre empresas e DHs, sendo responsável pela elaboração dos Princípios Orientadores da ONU sobre Empresas e Direitos Humanos, os quais foram aprovados em 2011 por consenso pelo Conselho de Direitos Humanos. Esses princípios constituem o principal documento na área até hoje. 7

Todavia, apesar das diversas iniciativas para regular as ETNs, até o momento nenhum instrumento regulatório é juridicamente vinculativo ou cria obrigaçóes diretas para as empresas. Ainda recai sobre os Estados assegurar a proteção dos $\mathrm{DHs}$ e, portanto, monitorar, fiscalizar e responsabilizar as ETNs em caso de descumprimento das obrigaçóes de DHs.

Em contrapartida, a partir dos anos 1980, com a difusão do ideário neoliberal, o que se observa é uma tendência à desregulamentação da atividade privada por parte do Estado e de diminuição da proteção dos $\mathrm{DH}$ s, com o fim de atrair investimentos. As ETNs, por sua vez, passaram a adotar medidas de automonitoramento, por meio da RSC. Como resultado, as organizaçóes internacionais começaram a ocupar a agenda de regulação da atuação das transnacionais apoiando-se em marcos normativos de lógica voluntarista, ao mesmo tempo que reforçam a RSC.

O problema, assim posto, não está na centralidade do Estado na proteção dos DHs, mas na adoção de políticas neoliberais, que revisaram o papel deste e transferiram para as ETNs a capacidade de autorregulagem por meio da RSC, como abordado a seguir.

\subsection{A origem neoliberal da RSC}

A origem e a consolidação do movimento de RSC a partir dos anos 1980 estão relacionadas a fatores como: i) a difusáo de uma agenda neoliberal e a consequente desregulaçáo da atividade privada pelo Estado; ii) a necessidade de legitimação das ETNs, diante desse fenômeno; iii) a crescente discussão sobre RSC no meio acadêmico, com a adesão de empresas; e iv) o surgimento de diversas organizaçóes de RSC, a fim de validar tais dimensóes práticas.

Para compreender a relação entre a RSC e a agenda neoliberal, é necessário entender primeiramente o próprio modelo neoliberal. Em sua agenda, há a defesa e a disseminação da ideia de eficiência estatal. A partir dessa lógica, o Estado deve agir como se empresa privada fosse, o que justificaria a busca pela redução de custos. Sua tradicional função de proteçáo social passa a ser negligenciada por meio da redução de suas políticas sociais (Brown, 2009, p. 39-40).

Dentro do escopo do projeto neoliberal, a partir dos anos 1980, promoveram-se a abertura comercial e financeira, a privatização de empresas estatais, a desregulamentação das relações de trabalho e a compressão do padrão de proteção social. Tais medidas contribuíram para que parcela da população passasse a questionar a atuaçáo das empresas, uma vez que a retirada de determinadas garantias sociais prejudicou os cidadáos enquanto as favorecia.

Entre as políticas adotadas pelo governo Thatcher a partir de 1979, estáo, por exemplo: i) o desmantelamento dos movimentos sindicalistas britânicos por meio da restrição de sua atuação e da imposição de sançôes; ii) a remoção da exigência de dedução de contribuiçóes sindicais dos empregados, contando para isso com o apoio de grande parte da imprensa para colocar a opiniáo pública contra os sindicatos; iii) a desregulamentação do mercado financeiro, o que possibilitou a criaçáo de um mercado mais complexo; e iv) privatizaçóes - entre 1982 e 1986, foram desestatizadas 
mais de 22 empresas, incluindo companhias aéreas, de telecomunicação e petrolíferas (Kinderman, 2012). Além disso, houve mudanças em políticas sociais, como nas áreas de saúde e de educação.

Não por acaso, os movimentos de RSC surgem justamente nos países em que as políticas neoliberais foram implementadas de maneira mais profunda, como Reino Unido e Estados Unidos. Logo, a RSC surge para compensar a ausência institucional do Estado e, ao mesmo tempo, legitimar a atuação das empresas, uma vez que, diante da sociedade, elas não representam o bem-estar coletivo ${ }^{8}$ (Tsutsui e Lim, 2015, p. 41). Segundo Kinderman (2012, p. 3, tradução nossa), "a RSC tem servido para legitimar as reformas neoliberais ex ante, bem como para responder ex post às pressóes geradas pela liberalização e por um ambiente neoliberal".

Entre 1980 e 2000, as iniciativas dos Estados em regular as ETNs por meio de tratados ficaram estagnadas, ainda que alguns instrumentos voluntários já existissem. Diante da inércia dos Estados, surge a discussão sobre RSC em meio ao ambiente empresarial e, principalmente, dentro do meio acadêmico, ganhando cada vez mais relevância entre economistas e administradores (Carroll, 1999, p. 269).${ }^{10}$ Com o avanço da discussão sobre RSC, em 2000, a ONU apresentou o Pacto Global, ${ }^{11}$ que é claramente uma assimilação, pela organização, do movimento de RSC e se utiliza da própria lógica de RSC, qual seja, regras voluntárias, formuladas pelas próprias empresas, divulgadas por códigos de conduta e relatórios.

No espaço acadêmico, os conceitos de RSC, desenvolvidos especialmente nos anos 1980, aparecem com o discurso de que as empresas, além de buscar o lucro, devem promover o bem-estar social; de que os negócios devem tornar-se responsáveis perante a sociedade; e de que é preciso contribuir para o avanço da sociedade, sendo-lhes, portanto, uma estratégia adequada. Além disso, estudos que buscavam estabelecer a relação entre reputação e performance financeira também passaram a interessar aos estudiosos (Carroll, 1999).

Entre os autores, entretanto, era bastante difícil chegar a um consenso sobre o que seria um comportamento socialmente responsável. A unanimidade, de fato, existia em torno da ideia de que a RSC ia além das obrigaçôes legais e, assim, deveria ser voluntária.

8. Lembrando que, nesse mesmo sentido, os escândalos envolvendo as empresas deixam de ser direcionados aos Estados, e a responsabilidade passa a ser ligada diretamente às empresas (Tsutsui e Lim, 2015, p. 40). Podemos citar, como exemplo, o caso do desastre químico ocorrido em 3 de dezembro de 1984 na cidade de Bhopal, estado de Madhya Pradesh, na Índia. Na ocasião, cerca de 45 t do perigoso gás isocianato de metila escaparam de uma fábrica de inseticidas na propriedade da subsidiária indiana da empresa americana Union Carbide, matando milhares de pessoas imediatamente. Investigações estabeleceram que os procedimentos operacionais e de segurança abaixo do padrão na planta com falta de pessoal levaram à catástrofe. Disponível em: <https://bit.ly/3hcFnhR>.

9. "CSR has served to legitimate neo-liberal reforms ex ante, as well as responding ex post to the pressures generated by liberalization and by a neo-liberal environment."

10. Muitos autores citam a publicação do livro The Social Responsibilities of the Businessman pelo economista americano Howard R. Bowen, em 1953, como sendo o marco inicial da literatura moderna sobre RSC. Não obstante, a literatura sobre o tema à época era escassa e a responsabilidade era focada na figura do empresário e na ideia de que decisões e ações empresariais poderiam afetar a vida dos cidadãos de diferentes formas (Carroll, 1999, p. 269).

11. 0 pacto é uma iniciativa voluntária, desenvolvida pelo ex-secretário-geral da ONU Kofi Annan, a fim de mobilizar a comunidade empresarial internacional para comprometer-se em alinhar suas operações com dez princípios sobre DHs, trabalho, meio ambiente e luta contra a corrupção. 0 pacto conta com milhares de empresas de diferentes setores e instituiu uma regra que determina que somente podem continuar fazendo parte da rede como membros aqueles que enviarem relatórios anuais informando sobre o seu progresso na implementação dos princípios básicos do pacto. Disponível em: <http://pactoglobal.org.br/o-que-e/>. 


\section{GRÁFICO 1}

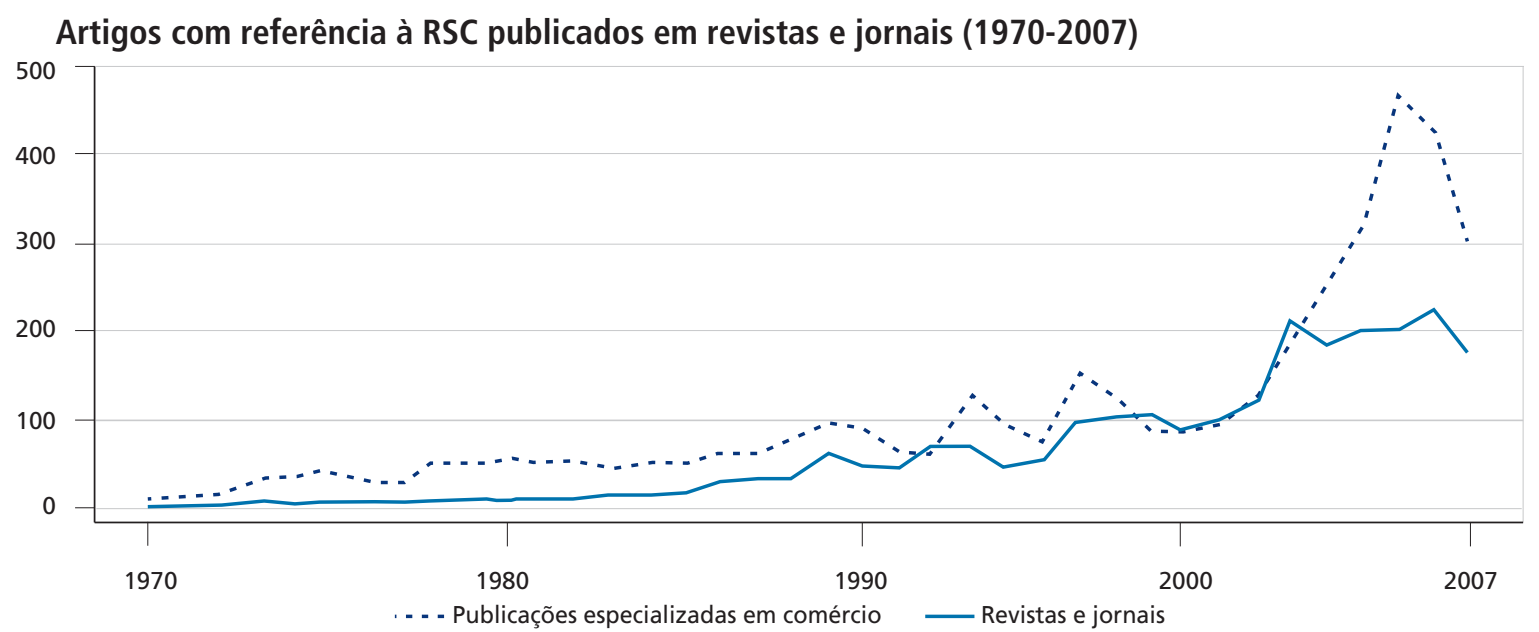

Fonte: Tsutsui e Lim (2015, p. 45).

No período em questão, também foram criadas as primeiras organizaçôes de RSC. Tsutsui e Lim (2015, p. 45) citam como exemplos a Coalition of Environmentally Responsible Companies (1989), a Business for Social Responsibility (1992) e o Boston College Center for Corporate Citizenship (1985), com destaque em âmbito internacional para o International Business Leaders Forum (1990), o World Economic Forum (1987) e o World Business Council for Sustainable Development (1995). Outro exemplo é a Business in the Community (BITC), organizaçáo líder em RSC no Reino Unido, fundada em 1982 (Kinderman, 2012, p. 7). Todas elas são organizaçôes sem fins lucrativos, que contam com a participação de empresas privadas para desenvolver as ideias de RSC - o que, portanto, sustenta o argumento de que o avanço da RSC está associado ao avanço do neoliberalismo. A título de exemplo, cabe lembrar que umas das principais medidas neoliberais adotadas pelo governo Thatcher foi a privatização de empresas estatais. Essas empresas recém-privatizadas, por sua vez, logo se tornaram membros da BITC a fim de demonstrar que ainda existia uma preocupação social, já que o Estado estava preocupado em criar um sistema de regulação privado. Desse modo, "a RSC ajudou a legitimar as empresas há pouco privatizadas e a compensar a repercussão decorrente das demissóes em larga escala" ${ }^{12}$ (Kinderman, 2012, p. 15, tradução nossa).

A institucionalização da RSC passou a ser vista de forma positiva pela sociedade. Muitos movimentos sociais, apesar de criticarem a atuação das empresas, não criticavam diretamente a RSC, já que esta adquiriu uma imagem positiva, qual seja: contribuir para uma mudança no comportamento das companhias. E, por meio do Pacto Global, a própria ONU se torna o locus de divulgação das empresas que pretendem ser reconhecidas como socialmente responsáveis.

Em síntese, percebe-se que a RSC não decorre de uma ameaça de regulação das ETNs por parte do Estado. Pelo contrário, as regulaçóes que restringem o livre comércio, tanto local quanto a nível internacional, ${ }^{13}$ foram diminuindo, e a RSC surge, entáo, para compensar essa ausência institucional

12. "CRS has helped to legitimate newly privatized companies and compensate for the fall out arising from large-scale layoffs."

13. As iniciativas que buscavam regular as ETNs são deixadas de lado, sendo a última a da OIT, em 1977. No nível local, o Estado também passa por um processo de desregulação. Esse cenário cria um ambiente favorável ao comércio internacional e ao IED, que passa a ser cada vez mais cotejado por meio de TBls. 
do Estado, ao mesmo tempo que legitima a atuação das empresas junto à sociedade, com impacto sobre seu valor de mercado.

\section{OS ACORDOS DE INVESTIMENTO E A INSERÇÃO DA RSC}

O desenvolvimento do regime internacional de investimentos não ficou circunscrito às iniciativas multilaterais que visavam controlar as atividades das ETNs. De fato, tal regime é atualmente governado, sobretudo, por meio de TBIs ou de acordos mais abrangentes que contêm cláusulas sobre investimentos. Por isso, a inserção de cláusulas de RSC em acordos de investimento tende a ser vista de forma positiva, já que preencheria uma lacuna antiga referente à criaçáo de um instrumento internacional multilateral vinculante que regule a atuação das ETNs, unindo o regime de investimento ao dos DHs.

Contudo, pretende-se neste artigo desafiar o argumento de que a inclusão de cláusulas de RSC em TBIs, tout court, assegura a proteção efetiva de DHs. Para tanto, na sequência, são apresentadas duas análises: a primeira acerca dos modelos tradicionais de acordos de investimento e a segunda sobre o modelo brasileiro, o ACFI.

\subsection{As cláusulas de RSC nos acordos de investimento}

Entre 1959 - ano do primeiro tratado - e 1991, mais de quatrocentos TBIs foram assinados no mundo (Guzman, 1998, p. 652). A ampla maioria desses TBIs envolvia um país desenvolvido e um em desenvolvimento, com a principal finalidade de proteger o investidor. Todos os países desenvolvidos, assim como mais de noventa países entáo classificados como em desenvolvimento, faziam parte de pelo menos um TBI.

Os modelos dos TBIs são estabelecidos, normalmente, pelos países desenvolvidos. Segundo Guzman (1998, p. 660), a submissão dos países em desenvolvimento aos TBIs precisa ser compreendida dentro de um contexto de ausência, no direito internacional, de mecanismos que ofereçam proteção ao investimento perante o Estado receptor. Tal ausência afeta o poder de barganha dos Estados durante as negociaçóes, levando os países em desenvolvimento, desejosos em encorajar o ingresso de investimentos externos, a ceder a modelos propostos por países desenvolvidos exportadores líquidos de capital.

Como consequência, os instrumentos se restringem a regular o interesse dos investidores e não dialogam com outros instrumentos internacionais, especialmente, os instrumentos de DHs. Segundo Sornarajah (2010, p. 228, tradução nossa), DHs raramente são mencionados em TBIs, contudo,

os direitos humanos assumirão maior significado no futuro e, portanto, terão que ser acomodados nos tratados de investimento. A tendência das elites em muitos Estados voltada para o neoliberalismo tem sido atrair investimentos estrangeiros, mesmo à custa dos direitos humanos. ${ }^{14}$

Ao inserir cláusulas de RSC nos TBIs, o objetivo é incorporar mais obrigaçôes aos investidores a fim de incentivá-los a respeitar os DHs e as leis ambientais no Estado anfitrião. Todavia, simplesmente inserir cláusulas estabelecendo que os Estados incentivem as empresas que operam em seu território

14. "(...) human rights will assume greater significance in the future and will therefore have to be accommodated within investment treaties. The tendency of elites in many states geared to neo liberalism has been to attract foreign investment even at the cost of human rights." 
ou estão sujeitas à sua jurisdição a incorporar voluntariamente padróes de RSC em suas práticas e políticas internas, por si só, não apresenta avanços em termos de criação de obrigaçôes para as ETNs.

Embora essas disposiçóes ainda não tenham um padrão, sua aplicação baseia-se, em grande parte, na supervisão interna dos Estados. Não obstante, destaca-se sempre a utilização da linguagem voluntária com relação à conduta das empresas. Em outras palavras, o Estado deve incentivar as empresas a adotarem mecanismos de RSC; no entanto, a responsabilidade ainda é centrada na figura do Estado. Além disso, tais disposiçôes não trazem grandes inovaçôes - são uma reprodução do que já é proposto pelos outros instrumentos internacionais, como os Princípios Orientadores da ONU. ${ }^{15}$ Os princípios representam o fortalecimento da transferência do controle político, ou de regulaçáo, para agentes privados como as ETNs por meio da RSC.

Os conceitos de RSC, por sua vez, baseiam-se fundamentalmente em duas premissas:

- o dever das ETNs é cumprir as obrigaçóes legais (que, dentro do recorte neoliberal, devem ser mínimas e, portanto, não devem intervir na atuação do setor privado); e

- as ETNs, por motivos éticos e de forma voluntária, buscam se comprometer em promover o bem-estar (papel tradicionalmente atribuído ao Estado) nos países em que atuam.

Nesse sentido, a política social é voluntária, e não um direito; é focalizada, e não universal; e reforça a sua presença, mas não é vinculante.

Além do mais, a voluntariedade explica o motivo pelo qual existe uma tendência em excluir tais cláusulas de arbitragens, seja investidor-Estado, seja Estado-Estado, reforçando o caráter de automonitoramento da RSC. Nesse sentido, a partir de uma perspectiva neoliberal, o Estado, especialmente em economias exportadoras de capital, reluta em adotar medidas e legislaçóes que limitem a atuação das empresas ou as prejudiquem na "competição internacional", principalmente no que tange a regras de proteçáo de DHs. Assim, esse Estado tende a favorecer uma abordagem "voluntária” e "privada" de RSC, como a presente nos TBIs.

Segundo Backer (2015, p. 64, traduçáo nossa), "os direitos humanos tornaram-se parte do discurso do mercado privado, bem como do sistema estatal". ${ }^{16} \mathrm{O}$ Estado se exime do ônus de regular, enquanto a empresa assume esse papel, ao mesmo tempo que invoca a RSC como uma forma de obter uma imagem positiva junto à sociedade. Para as corporaçóes, reputação da marca e imagem importam, e toda uma indústria profissional surgiu para atender à necessidade de protegê-las e preservá-las, pois é inegável que essa nova maneira de relacionar-se com a sociedade, à medida que abre novos mercados e incrementa o número de investidores, maximiza o valor da companhia.

As empresas buscam firmar essa imagem positiva por meio de documentos que tornam públicos seus valores, suas políticas e suas práticas de RSC, a exemplo dos códigos de conduta. A realidade, no entanto, revela que a RSC tende a não sair do papel, no sentido de que poucas empresas demonstram submeter suas atividades a mecanismos efetivos de monitoramento ou tomar medidas corretivas em casos de violação dos DHs.

15. Esses princípios baseiam-se em duas premissas: i) o Estado é o principal responsável pela proteção internacional dos DHs; e ii) em decorrência da responsabilidade corporativa, as ETNs têm a obrigação de respeitar os DHs e devem, portanto, submeter suas atividades a mecanismos de automonitoramento e tomar medidas corretivas em casos de violações de tais direitos.

16. "(...) human rights have become part of the discourse of the private market, as well as of the state system." 
Dados publicados no 2017 United Nations Global Compact Progress Report: business solutions to sustainable development demonstram que a opção pela adoção de documentos é significativamente maior do que, por exemplo, a de mecanismos de monitoramento, denúncia e que apresentem a implementação das açóes tomadas pelas empresas, mecanismos esses adotados por apenas $29 \%$ das companhias cobertas pelo relatório (UNGC, 2017, p. 31). A porcentagem de empresas que realizam avaliaçóes de impacto ainda é baixa, sendo 58\% na área ambiental, 31\% na área laboral, 22\% em anticorrupção e apenas $15 \%$ em DHs.

Na prática, violaçôes seguem acontecendo, apesar do crescimento exponencial de mecanismos de RSC. Informações disponíveis sugerem que, de 2008 a 2014, "houve um aumento sem precedentes nas violaçóes dos DHs em todo o mundo; cerca de 70\%, de acordo com um novo relatório" (tradução nossa). ${ }^{17}$ Também alarmantes são as revelaçôes de que a exploração do trabalho forçado possa gerar lucros de US\$ 150 bilhóes por ano ${ }^{18}$ e de que $11 \%$ das empresas do Reino Unido considerem provável a utilizaçáo de trabalho escravo em suas cadeias de suprimento. Pesquisas recentes também indicam que $72 \%$ dos profissionais britânicos não sabem o que acontece em suas cadeias de suprimentos para além do segundo nível de fornecedores, e apenas $11 \%$ dizem ter visibilidade de toda a cadeia produtiva. ${ }^{19}$

Logo, o que se observa é que os sistemas voluntários não estão conseguindo coibir as violaçôes de DHs cometidas por ETNs ou limitam-se a tão somente identificar práticas contrárias a esses direitos. Por consequência, se os acordos de investimento não dispuserem de outros mecanismos que criem incentivos ao cumprimento desse tipo de cláusula, a RSC tende a ter uma função apenas exortatória. No que diz respeito ao dever das empresas, as cláusulas de RSC nos TBIs geralmente evitam, em seus textos, a linguagem de obrigação legal e utilizam a palavra should, e não must. ${ }^{20}$ Para Santoso (2017, p. 543), essa escolha de termos representa uma opção deliberada por não impor obrigaçóes legais às ETNs. No entanto, a ausência de uma obrigação legal implicitamente permite que algumas companhias violem os DHs para obter lucro, na medida em que a obrigação é apenas de cunho moral. Os TBIs, portanto, mais que apenas inserirem cláusulas de RSC: eles precisam avançar em mecanismos de monitoramento, denúncias e implementaçóes de açôes das empresas.

\subsection{O que esperar da RSC no modelo brasileiro de acordos de investimento}

Os ACFIs propostos pelo Brasil apresentam alguns elementos que os diferenciam dos TBIs tradicionais e surgem justamente em um contexto de críticas a estes. ${ }^{21}$ Para Morosini e Badin (2017, p. 222), as reivindicaçôes por reformas no regime de investimento internacional estão ligadas ao desejo de relaçôes mais equilibradas entre as partes e os atores que fazem parte e se beneficiam dos acordos. Esses autores afirmam ainda que os ACFIs, enquanto modelo proposto pelo Brasil, são motivados por

17. "(...) there has been an unprecedented rise in human rights violations globally, up $70 \%$ according to a new report. Workers' rights are seriously compromised and rural and indigenous communities are facing land grabs and forced displacement amid growing demand for low-cost labour and resources". 0 relatório mencionado na reportagem é o 2014 Human Rights Risk Atlas, publicado pela firma de consultoria de riscos Maplecroft. Disponível em: <https://bit.ly/3w6yR10>.

18. Disponível em: <https://glo.bo/3h10XXx>.

19. Disponível em: <https://bit.ly/3quzXD5>.

20. Exemplos de tal disposição de RSC podem ser encontrados no art. 16 do Acordo de Investimento Bilateral Benin-Canadá, de 2013, e no art. 12 do Acordo de Investimento Bilateral Argentina-Catar, de 2012.

21. Entre as críticas, citam-se: restrições à liberdade regulatória e à capacidade dos Estados de adotarem políticas públicas; tratamento mais favorável do investidor estrangeiro em relação ao investidor nacional; elevado custo econômico e político dos procedimentos arbitrais; imposição de onerosas indenizações; e falta de transparência das decisões arbitrais. Disponível em: <https://bit.ly/3y5CLZJ>. 
esse desejo de reforma, o que levou as autoridades brasileiras a revisar regras antigas, incluir novas e até mesmo excluir outras que eram entendidas como contrárias ao status de país em desenvolvimento, como o do Brasil. Diante dessas mudanças, analisamos se o modelo brasileiro oferece avanços quanto à responsabilidade das empresas.

Por trás desse modelo de acordo, encontram-se os seguintes fundamentos: ação diplomática, respeito à legislaçáo interna e obrigaçóes mais equilibradas entre investidores nacionais e estrangeiros, bem como entre o investidor e o Estado anfitrião (Morosini e Badin, 2017, p. 224). Outro aspecto importante é a possibilidade de criar um espaço para o diálogo com a sociedade, que já aparece de forma institucionalizada nos ACFIs brasileiros em um dos seus pilares - agendas temáticas para cooperação e facilitação dos investimentos.

Entre outras regras, tal pilar prevê a elaboração de uma agenda temática entre as partes. Essas agendas são construídas bilateralmente e podem variar de acordo com o parceiro de investimento, dependendo de suas prioridades políticas e do perfil do investidor. Hoje elas incluem, por exemplo, programas envolvendo transferência de tecnologia (Morosini e Badin, 2017, p. 224-225).

O modelo de ACFI incentiva as partes a negociar compromissos especiais, cronogramas adicionais e outros acordos suplementares como segmento do acordo principal, a fim de expandir ou detalhar as agendas temáticas, ou seja, esse espaço poderia ser uma oportunidade para incluir uma agenda de DHs mais ampla nesses acordos. A inserçáo dessa agenda, porém, depende da negociação entre as partes envolvidas.

Outro aspecto relevante refere-se à utilização da cláusula de arbitragem como procedimento de solução de controvérsias. A cláusula de arbitragem nos TBIs recebe crescentes críticas, pois permite aos investidores estrangeiros evitar os órgãos administrativos e tribunais locais (Morosini e Badin, 2017, p. 1), enquanto os impactados pelo investimento não têm jurisdição, a não ser perante a justiça interna do Estado hospedeiro (Bernaz, 2017, p. 138-139).

Dito isso, a forma como a arbitragem hoje está estruturada constitui um sério obstáculo à proteção de DHs, pois: i) as violaçôes são perpetradas no Estado hospedeiro, mas este não pode propor reclamação; ii) em muitos casos, as empresas são cúmplices de violaçóes, e não o principal violador de DHs, ou, ainda, os Estados são coniventes com essas violaçóes; e iii) mesmo que existam cláusulas de RSC ou proteção de DHs nos TBIs, elas estão excluídas da arbitragem.

Os ACFIs têm buscado instituir mecanismos alternativos de solução de controvérsias e não permitem que investidores iniciem diretamente um procedimento arbitral contra os Estados. A ideia é implementar um modelo baseado em consulta, negociaçóes e mediação. Representantes do governo brasileiro sublinham que, ainda que haja previsão de arbitragem Estado-Estado nos acordos, ela não deve ser o principal mecanismo para a solução de disputas (Morosini e Badin, 2016). Somente se o comitê conjunto não for capaz de elaborar uma solução mutuamente satisfatória, o Estado da parte afetada poderá apresentar à outra parte um pedido por escrito para o estabelecimento de um tribunal arbitral. Em outras palavras, o comitê conjunto é uma etapa obrigatória antes do procedimento arbitral (Morosini e Badin, 2017, p. 234). Com relação a esse comitê, entre suas atribuiçóes está a de monitorar a implementação e a execução do acordo. Não só isso, ele pode convidar o setor privado e a sociedade civil a integrá-lo, quando aplicável (op. cit., p. 226). 
Em 2019, o Brasil instituiu o Ombudsman de Investimentos Diretos (OID), ${ }^{22}$ cujo ponto focal, papel que é exercido pela Secretaria Executiva da Câmara de Comércio Exterior (Camex), deve dar assistência e orientação tanto aos investidores externos no Brasil quanto aos brasileiros em relação aos seus investimentos no exterior. O OID também pode apresentar soluçóes para questionamentos e dar seguimento a demandas dos investidores, em especial nos países com os quais o Brasil tenha acordo de investimento em vigor. ${ }^{23}$ Tanto o ponto focal quanto o comitê conjunto têm a finalidade de promover o intercâmbio de informação entre as partes e, em caso de controvérsia, implementar mecanismos de consultas, negociaçôes e mediação (Morosini e Badin, 2017, p. 227).

Destaca-se ainda que, conjuntamente ao OID, foi lançado o novo modelo do Ponto de Contato Nacional (PCN) da OCDE para empresas multinacionais operando no Brasil. O PCN atua como um fórum no qual interessados podem apresentar reclamaçóes contra multinacionais de países aderentes que supostamente descumpriram preceitos das diretrizes da OCDE. ${ }^{24} \mathrm{O}$ Brasil possui uma lista de reclamaçôes nesse âmbito. ${ }^{25}$

O modelo brasileiro de acordos de investimento possui um anexo definindo princípios e padróes de RSC, com o objetivo de incentivar os investidores estrangeiros a respeitar os $\mathrm{DHs}$ e as leis ambientais no país anfitrião. Cabe destacar que o rol de princípios e padróes tende a ser mais amplo do que em TBIs tradicionais. Todos os acordos assinados pelo Brasil seguindo esse modelo contêm cláusulas como respeitar a proteção do meio ambiente e o desenvolvimento sustentável; respeitar os direitos humanos daqueles envolvidos nas atividades dessas empresas; estimular a cooperação com comunidades locais; abster-se de ingerência indevida nas atividades políticas locais; e apoiar e manter princípios de boa governança. ${ }^{26}$

O modelo brasileiro ainda avança no sentido de que as questóes envolvendo RSC podem ser levadas ao comitê conjunto e ao ponto focal, que são estruturas importantes de monitoramento e gestáo criadas pelos ACFIs. Contudo, embora a inclusão de cláusulas de RSC mais amplas no modelo brasileiro pareça expandir e criar um novo mecanismo de proteçáo aos DHs e de responsabilização das empresas, estas seguem tendo como base uma proteçáo legal de soft law, ou seja, voluntária; e, embora questóes de RSC possam ser levadas a essas estruturas internas previstas no acordo, elas continuam excluídas da arbitragem.

Não se pode ignorar que economias como a brasileira, que dependem significativamente do capital estrangeiro, tendem a adotar políticas favoráveis para atrair investimentos, o que pode significar colocar as preocupaçóes com os $\mathrm{DH}$ em segundo plano. Em cenários como esse, existe uma preocupaçáo de que as violaçóes de $\mathrm{DH}$ acabem por não ter os encaminhamentos desejados nos procedimentos levados a cabo nos referidos órgãos presentes nos ACFIs. Ademais, entende-se que a lógica adotada nos ACFIs incorre no risco de que instrumentos de RSC passem a ser vistos como uma solução para os abusos sistêmicos dos $\mathrm{DH}$ e acabem contribuindo para um afastamento de medidas mais eficazes. Visando ampliar a efetividade dos ACFIs enquanto instrumentos equilibrados que promovam o investimento estrangeiro ao mesmo tempo que salvaguardem as comunidades impactadas, pode-se

\footnotetext{
22. Disponível em: <https://bit.ly/3qv96GV>.

23. Disponível em: <https://bit.ly/3qv96GV>.

24. Disponível em: <https://bit.ly/3gsXH5Q>.

25. Disponivel em: <http://mneguidelines.oecd.org/database/>

26. Disponível em: <https://bit.ly/3y5CLZJ>.
} 
pensar em algumas alternativas factíveis. Primeiramente, vincular as cláusulas de RSC dos acordos a tratados com força obrigatória de $\mathrm{DHs}$ ratificados pelo Brasil. Em adição, sugere-se que tais cláusulas também incorporem linguagem relativa ao direito costumeiro internacional. Assim, durante o exercício de interpretação do julgador acerca da RSC, este poderá ampliar a margem de proteção de DHs pela via do costume internacional.

Em matéria de procedimentos, sugere-se que as cláusulas de RSC também sujeitem-se ao mecanismo de solução de controvérsias Estado-Estado. Dessa forma, o compromisso de assegurar o cumprimento das cláusulas de RSC não ficaria apenas a cargo do ombudsman e do comitê conjunto. Haveria, assim, a possibilidade de que tribunais arbitrais pudessem adjudicar essas cláusulas, vinculando os Estados a obrigaçóes de DHs, ainda mais se as cláusulas de RSC incorporarem linguagem de direito internacional vinculante.

\section{PROPOSTAS PARA INSTRUMENTALIZAR AS OBRIGAÇÕES DAS ETNs PARA ALÉM DA RSC}

A partir da análise anterior, conclui-se que a RSC não deixa de ser um instrumento importante no sentido de reconhecer que as ETNs, em sua atuação, têm obrigações com os DHs. A RSC, porém, está construída dentro de uma lógica neoliberal, que tem limitaçôes. Essas limitaçôes encontram-se na ideia de que uma regulação vinculante que responsabilize as empresas comprometeria a liberdade de mercado e a busca por vantagens competitivas. Como consequência, a autorregulação apresenta-se como uma alternativa à responsabilidade das empresas, eximindo o direito internacional de formular normas de hard law.

A inserção da RSC nos acordos de investimento representa uma fusão entre o voluntarismo das empresas e o quadro regulatório de normas de soft law existente, a exemplo das normas da OCDE. Contudo, a simples unificação desses marcos não produz mudanças efetivas. No caso dos acordos de investimento, ambos os modelos não criam obrigaçóes diretas para o investidor, de modo que o sistema continua centralizado no Estado. Logo, cabe a este o dever de proteger os DHs, e, para tanto, deve estabelecer marcos regulatórios para as ETNs e garantir às vítimas de violação acesso à justiça e a mecanismos de reparação.

Romper com essa assimetria normativa, em que o investidor tem seus direitos assegurados e a proteção dos DHs está relegada ao soft law, exige defender que as normas relativas às empresas e aos DHs tenham, pelo menos, a mesma força que as normas de proteção aos investimentos. Por isso, é fundamental procurar estabelecer um marco regulatório que abranja a atividade das ETNs.

Uma das iniciativas que visam suprir as lacunas existentes no atual sistema é a proposta de um marco internacional legalmente vinculante. Em 2014, foi criado um grupo de trabalho na ONU para elaborar um tratado internacional sobre empresas e $\mathrm{DHs} .{ }^{27} \mathrm{O}$ draft zero para negociação de um tratado internacional sobre DHs e empresas foi apresentado em $2018^{28}$ e, em 2020, foi publicado o segundo draft, revisado do tratado vinculante. ${ }^{29}$ São majoritariamente dois os objetivos do instrumento:

27. A Resolução no 26/9, Elaboration of an international legally binding instrument on transnational corporations and other business enterprises with respect to human rights, define a criação de um grupo de trabalho para estabelecer normas vinculantes sobre empresas e DHs (OHCHR, 2014a).

28. Para uma análise do draft zero, ver OHCHR (2018), Guamán (2018) e Deva (2014).

29. Sobre o segundo draft do tratado internacional sobre empresas e DHs, checar OHCHR (2020). 
i) suprir uma lacuna existente no sentido de definir quais são as obrigações de DHs das ETNs; e ii) criar remédios efetivos em caso de violação desses direitos, sendo esse o tópico mais crucial, uma vez que não há nenhum instrumento hoje que inclua algum mecanismo vinculante de responsabilização. ${ }^{30}$

Muitas questóes foram abordadas durante as sessóes do grupo de trabalho intergovernamental aberto sobre ETNs e sobre outras empresas no âmbito dos DHs que levaram à elaboração do draft zero, ${ }^{31}$ porém destacam-se as seguintes questôes controversas:

- a definição das obrigaçóes das empresas sob o direito internacional;

- o escopo proposto de um instrumento vinculante sobre empresas e DHs; e

- o estabelecimento de mecanismos efetivos de responsabilização das ETNs e da obrigação extraterritorial dos Estados de proteger os DHs.

Contudo, o draft zero não deu respostas a esses anseios, e as controvérsias em torno dos pontos mencionados continuam a permear o debate, à medida que se avança na elaboração do texto do tratado. Cabe ressaltar, contudo, que os países considerados desenvolvidos ${ }^{32}$ (União Europeia, Estados Unidos, Japão, Reino Unido, entre outros) seguem relutantes com relação a esse instrumento e, portanto, têm se posicionado de maneira a defender os instrumentos já existentes, como os Princípios Orientadores da ONU. Tal posicionamento reforça a necessidade de um tratado internacional sobre DHs e empresas como forma de avanço no campo da responsabilidade das ETNs, preenchendo a lacuna existente: a ausência de uma norma vinculante, que crie obrigaçóes para as empresas e que promova um ambiente mais igualitário entre os países.

Ao mesmo tempo, sem desconsiderar a proposta do tratado, outras iniciativas poderiam ser levadas em consideração em outras frentes. Defende-se que reconhecer a responsabilidade extraterritorial das empresas-mães seria um dos maiores avanços na relação entre empresas e DHs. A despeito da forma transnacional com que as empresas atuam, a responsabilidade destas é limitada, uma vez que cada entidade é compreendida de maneira separada do seu Estado de incorporação (Muchlisnki, 2010), isto é, o Estado da empresa-mãe não tem jurisdição para julgar casos de violação de DHs cometidos pelas subsidiárias.

Assim, segundo Santoso (2017, p. 535), há um abuso da forma corporativa, pois os grupos corporativos apropriam-se da doutrina e criam, portanto, um véu de proteção ao estabelecer subsidiárias para facilitar ou gerir investimento, comércio e futuros riscos legais. Portanto, "quando as empresas controladoras, exercendo o controle de fato ou de direito sobre as atividades das suas subsidiárias facilitam, permitem, se beneficiam ou negligentemente não conseguem impedir violaçôes de $\mathrm{DHs}$, a forma corporativa é utilizada para imunizar as empresas-mãe de responsabilidade" (Santoso, 2017, p. 535, tradução nossa).

Como explica Muchlinski (2010), a interposição de uma entidade legal entre as vítimas e as empresas que, de fato, são as controladoras do grupo tem o objetivo de evitar que a responsabilização seja alcançada pelas vítimas, ou seja, constata-se que a forma como o sistema hoje está estruturado

30. Para uma análise sobre a pertinência da elaboração de um instrumento internacional vinculante, consultar Roland et al. (2018).

31. Sobre as sessões do grupo de trabalho intergovernamental aberto sobre empresas transnacionais, ver OHCHR (2014b).

32. Sobre o posicionamento, especialmente da União Europeia, acerca do tratado, checar OHCHR (2018). 
prevê, acima de tudo, que as ETNs são sujeitas de direito interno do Estado onde operam. ${ }^{33}$ Uma vez estabelecida em determinado território, a empresa se vincula a determinada jurisdição. Ocorre que justamente essa limitação faz com que, muitas vezes, as empresas, visando à redução de custos e ao aumento dos lucros, busquem países com baixa proteção de $\mathrm{DHs}$ para lá se estabelecerem, o que também facilita a impunidade.

A fim de solucionar o problema, uma cláusula de extraterritorialidade poderia ser adotada em instrumentos como os TBIs. ${ }^{34}$ Tal cláusula efetivamente incorporaria mais obrigaçôes aos investidores, a fim de incentivá-los a respeitar os DHs e as leis ambientais no Estado anfitrião, dado que isso romperia com a barreira existente para açóes judiciais contra as ETNs em seus países de origem.

Além disso, a incorporação dessa cláusula nos ACFIs seria um grande avanço, enquanto modelo advindo de um país em desenvolvimento, onde o ingresso de investimento é significativamente maior que a saída. Tal cláusula, além de impor obrigações legais diretas às empresas, estenderia as obrigaçóes de regular e controlar os atores privados sob a jurisdiçáo do Estado hospedeiro ao Estado de origem do investimento. Adicionalmente, romperia com a lógica tradicional dos TBIs, que é a de proteger exclusivamente o investidor. Por fim, outro avanço nesse sentido seria exigir dos Estados signatários que incorporem em sua legislação nacional normas acerca do levantamento do véu corporativo, visando à proteção de $\mathrm{DHs}$, especialmente no âmbito do direito empresarial.

\section{CONSIDERAÇÕES FINAIS}

Neste artigo, evidenciou-se a relação entre a RSC e o neoliberalismo. Aquela segue a lógica deste, qual seja, a de que cabe ao Estado assegurar a liberdade de mercado, o que justificaria o estabelecimento de normas que facilitam a circulaçáo de capital. Ao mesmo tempo, a RSC assume o papel do Estado em termos de uma regulação protetiva de direitos, já que demonstra que as empresas estão comprometidas com a proteção social. Não obstante, a RSC tem o papel de demonstrar que as empresas fazem mais do que suas obrigaçôes legais, já que, efetivamente, cumprem uma obrigação legal que é mínima e adotam autorregulaçôes voluntárias que contribuem para o bem-estar coletivo. Dessa forma, a RSC estaria legitimando o Estado neoliberal e as próprias empresas.

Um número crescente de companhias tem incorporado medidas de RSC, o que reforça o discurso de que ela é benéfica à proteção dos DHs. Essa tendência acaba por se refletir nos TBIs, que têm incorporado cláusulas de RSC em seus textos. Além disso, uma crise generalizada de legitimidade com relação ao regime internacional de investimentos tem afetado os países do Norte e do Sul Global, impulsionando mudanças nesses marcos regulatórios.

Algumas consideraçôes, no entanto, precisam ser feitas. Primeiro, esse é um tema novo a ser regulado nos TBIs; as disposiçôes sobre o tema permanecem raras e, quando presentes, tendem a ser abstratas e não apresentam grandes avanços quanto à proteção dos DHs. Segundo, há um problema estrutural

33. Um caso recente é o da Kiobel v. Royal Dutch Petroleum. Em 2013, um tribunal norte-americano proferiu sua decisão em relação à alegada cumplicidade de uma corporação petrolifera estrangeira em abusos de DHs na Nigéria. Na apelação ao Second Circuit, a corporação afirmou que a empresa não poderia ser processada perante a corte norte-americana, uma vez que o direito internacional não reconhece a responsabilidade dessa empresa. 0 caso chegou até a Suprema Corte e, por fim, foi arquivado, sob o argumento de que as reclamações não tocam ou dizem respeito à jurisdição americana (Baumann-Pauly e Nolan, 2016, p. 248).

34. 0 debate acerca da desconsideração do véu corporativo vem ganhando espaço nas discussões sobre os acordos de investimento. Para tanto, ver Vastardis e Chambers (2018). 
nesse debate, que se deve ao fato de que os países onde está sediada a maioria das ETNs (e que são os proponentes desse modelo de acordo) seguem propagando um modelo neoliberal. Portanto, ao mesmo tempo que os países desenvolvidos demonstram sua preocupação com a proteção dos $\mathrm{DHs}$ ao estabelecer cláusulas de RSC, continuam a reforçar seu caráter não vinculante. Em terceiro lugar está a própria lógica da RSC, que tem sua origem e sua justificativa na redução do papel do Estado, diante de um processo de desregulaçáo, e, portanto, náo se legitima diante da própria ausência do Estado em garantir certos DHs.

Todavia, é possível avançar no marco dos TBIs e, nesse sentido, os ACFIs podem se apresentar como um novo espaço em que o investimento estrangeiro e os DHs possam dialogar de forma mais efetiva, já que os são um modelo pensado pelo Brasil, país em desenvolvimento e que busca atrair investimento estrangeiro, mas que, ao mesmo tempo, deseja assegurar sua soberania para a promoção de políticas públicas, como os DHs.

Os ACFIs apresentam, de fato, alguns avanços importantes, mas as cláusulas de RSC continuam sendo genéricas, não trazem um catálogo específico de $\mathrm{DHs}$ nem normas claras sobre quais são efetivamente as obrigaçóes das empresas para que, em caso de descumprimento, possa haver sanções adequadas. Deve-se ainda ressaltar que os ACFIs não fazem qualquer referência expressa a instrumentos internacionais relacionados à proteçáo dos $\mathrm{DH}$, além de utilizar uma linguagem de normas de soft law.

Por fim, alternativas apresentam-se como possíveis e não são excludentes. A proposta de uma cláusula de extraterritorialidade, tanto nos TBIs tradicionais quanto nos ACFIs, objetiva estimular o debate, evidenciando os limites da RSC em si e sua inserção nos TBIs, ao mesmo tempo que se compreende e se defende a necessidade de uma regulação vinculante.

\section{REFERÊNCIAS}

BACKER, L. C. Realising socio-economic rights under emerging global: regulatory frameworks: the potential impact of privatisation and the role of companies in China and India. In: DEVA, S. (Ed.). Socio economic rights in emerging free markets: comparative perspectives from India and China. London: Routledge, 2015.

BAUMANN-PAULY, D.; NOLAN, J. (Eds.). Business and human rights: from principles to practice. New York: Routledge, 2016.

BERNAZ, N. Business and human rights: history, law and policy. London: Routledge, 2017. (Bridging the Accountability Gap).

BROWN, W. Neoliberalism and the end of liberal democracy. In: Edgework: critical essays on knowledge and politics. Princeton: Princeton University Press, 2009. p. 37-59.

BUHMANN, K. The development of the 'UN framework': a pragmatic process towards a pragmatic output. In: MARES, R. (Ed.). The UN guiding principles on business and human rights: foundations and implementation. Leiden; Boston: Martinus Nijhoff, 2012.

BUSTURIA, A. A. L.-F. de. Derechos humanos, empresas transnacionales y responsabilidad social empresarial. Madrid: Instituto Berg, 2015.

CARROLL, A. B. Corporate social responsibility: evolution of a definitional construct. Business and Society, v. 38, n. 3, p. 268-295, 1999. Disponível em: <https://bit.ly/3jioQvn>. Acesso em: 10 nov. 2020.

DEVA, S. The human rights obligations of business: reimagining the treaty business. Geneva: [s.n.], 2014. Disponível em: <https://bit.ly/3hg1jZg >. Acesso em: 10 nov. 2020. 
FRIEDEN, J. A. Capitalismo global. Rio de Janeiro: Zahar, 2008.

GUAMÁN, A. El draft 0 del Binding Treaty: análisis crítico del contenido del texto y su adecuación con el objetivo de la Resolución 26/9. Cadernos de Pesquisa Homa, Juiz de Fora, v. 1, n. 6, 2018.

GUZMAN, A. T. Why LDCs sign treaties that hurt them: explaining the popularity of bilateral investment treaties. Virginia Journal of International Law, v. 38, p. 639-688, 1998.

HALL, S. The neoliberal revolution: Thatcher, Blair, Cameron - the long march of neoliberalism continues. Soundings: A Journal of Politics and Culture, 2011.

KINDERMAN, D. P. Free US up so we can be responsible! The co-evolution of corporate social responsibility and neo-liberalism in the UK, 1977-2010. Socio-Economic Review, v. 10, n. 1, p. 29-57, Jan. 2012. Disponível em: <https://ssrn.com/abstract=2213489>. Acesso em: 10 nov. 2020.

KNOX, J. H. The Ruggie rules: applying human rights law to corporations. In: MARES, R. (Ed.). The UN guiding principles on business and human rights: foundations and implementation. Leiden; Boston: Martinus Nijhoff, 2012.

LAGOUTTE, S. The UN guiding principles on business and human rights: a confusing 'smart mix' of soft and hard international human rights law. In: LAGOUTTE, S.; GAMMELTOFT-HANSEN, T.; CERONE, J. (Eds.). Tracing the roles of soft law in human rights. Oxford: Oxford Scholarship Online, 2016.

MARTÍN-ORTEGA, O. Empresas multinacionales y derechos humanos en el derecho internacional. Barcelona: Bosch, 2008.

MOROSINI, F. C.; BADIN, M. R. S. O Acordo de Cooperação e Facilitação de Investimentos: o que está por trás desta inovação regulatória? Pontes - Comércio e Desenvolvimento Sustentável, v. 12, n. 1, p. 9-12, 2016.

Reconceptualizing international investment law from Global South. FGV Direito SP Research Paper Series, n. 150, Sept. 2017. Disponível em: <https://ssrn.com/abstract=3039077>. Acesso em: 10 nov. 2020.

MUCHLISNKI, P. Limited liability and multinational enterprises: a case for reform? Cambridge Journal of Economics, v. 34, n. 5, p. 915-928, Sept. 2010.

OHCHR - OFFICE OF THE HIGH COMMISSIONER FOR HUMAN RIGHTS. Elaboration of an international legally binding instrument on transnational corporations and other business enterprises with respect to human rights. [s.l.]: OHCHR, 14 July 2014a. Disponível em: <https://bit.ly/3qDy475>.

Open-ended intergovernmental working group on transnational corporations and other business enterprises with respect to human rights. [s.l.]: OHCHR, 26 June 2014b. Disponível em: <https://bit. ly/3xfE3kM>. Acesso em: 10 nov. 2017.

Legally binding instrument to regulate, in international human rights law, the activities of transnational corporations and other business enterprises (zero draft). [s.l.]: OHCHR, 16 July 2018. Disponível em: <https://bit.ly/2SwRjT8>. Acesso em: 10 nov. 2020.

Legally binding instrument to regulate, in international human rights law, the activities of transnational corporations and other business enterprises (second draft). [s.l.]: OHCHR, 6 Aug. 2020. Disponível em: <https://bit.ly/3A6XApB>. Acesso em: 10 nov. 2020.

ROLAND, M. C. et al. Desafios e perspectivas para a construção de um instrumento jurídico vinculante em direitos humanos e empresas. Revista Direito GV, v. 14, n. 2, p. 393-417, 2018. Disponível em: <https:// bit.ly/3AgVXWD>. Acesso em: 10 fev. 2021.

SANTOSO, B. "Just business": is the current regulatory framework an adequate solution to human rights abuses by transnational corporations? German Law Journal, v. 18, n. 3, p. 533, May 2017. 
SORNARAJAH, M. The international law on foreign investment. 3rd ed. New York: Cambridge University Press, 2010.

TSUTSUI, K.; LIM, A. Corporate social responsibility in a globalizing world. Cambridge: Cambridge University Press, 2015.

UNGC - UNITED NATIONS GLOBAL COMPACT. 2017 United Nations Global Compact Progress Report: business solutions to sustainable development. [s.l.]: UNGC, 2017. Disponível em: <https://www. unglobalcompact.org/library/5431>. Acesso em: 10 nov. 2020.

VASTARDIS, Y. A.; CHAMBERS, R. Overcoming the corporate veil challenge: could investment law inspire the proposed business and human rights treaty? International and Comparative Law Quarterly, v. 67, n. 2, Apr. 2018, p. 389-423. Disponível em: <https://doi.org/10.1017/S0020589317000471>. Acesso em: 10 fev. 2021. 
Ipea - Instituto de Pesquisa Econômica Aplicada

\section{Assessoria de Imprensa e Comunicação}

\section{EDITORIAL}

\section{Coordenação}

Reginaldo da Silva Domingos

\section{Supervisão}

Carlos Henrique Santos Vianna

\section{Revisão}

Bruna Oliveira Ranquine da Rocha

Carlos Eduardo Gonçalves de Melo

Elaine Oliveira Couto

Lis Silva Hall

Mariana Silva de Lima

Marlon Magno Abreu de Carvalho

Vivian Barros Volotão Santos

Matheus Tojeiro da Silva (estagiário)

Rebeca Raimundo Cardoso dos Santos (estagiária)

\section{Editoração}

Aline Cristine Torres da Silva Martins

Mayana Mendes de Mattos

Mayara Barros da Mota (estagiária)

\section{Capa}

Herllyson da Silva Souza

The manuscripts in languages other than Portuguese published herein have not been proofread.

\section{Livraria Ipea}

SBS - Quadra 1 - Bloco J - Ed. BNDES, Térreo.

70076-900 - Brasília - DF

Fone: (61) 2026-5336

Correio eletrônico: livraria@ipea.gov.br 


\section{INSTRUÇÕES PARA SUBMISSÃO DE ARTIGOS}

1. O Boletim de Economia e Política Internacional (BEPI) tem como missão promover o debate sobre as relações internacionais do Brasil e o papel do país no mundo. A ênfase é em estudos de análise e avaliação da política externa brasileira, especialmente nas áreas de comércio exterior, cooperação internacional, governança global, integração regional, meio ambiente, relações bilaterais, relações com organizações internacionais e segurança internacional. Seu público-alvo são acadêmicos, técnicos, autoridades de governo e estudiosos das relações internacionais em geral.

2. Serão considerados para publicação artigos originais redigidos em espanhol, inglês ou português.

3. As contribuições não serão remuneradas, e a submissão de um artigo implicará a transferência dos direitos autorais ao Ipea, caso ele venha a ser publicado.

4. O trabalho submetido será encaminhado a pelo menos um avaliador. Nesta etapa, a revista utiliza o sistema double-blind peer review, ou seja, os autores e os pareceristas não são identificados em nenhuma fase da avaliação. A decisão dos avaliadores é registrada em pareceres, que serão enviados aos autores, mantendo-se em sigilo os nomes destes avaliadores.

5. Os artigos, sempre inéditos, deverão ter até 8 mil palavras, incluindo tabelas, figuras, quadros, espaços, notas de rodapé e referências.

6. A formatação deverá seguir os seguintes padrões: folha $A-4(29,7 \times 21 \mathrm{~cm})$; margens: superior $=3 \mathrm{~cm}$, inferior $=2 \mathrm{~cm}$, esquerda $=3 \mathrm{~cm}$ e direita $=2 \mathrm{~cm}$; em Microsoft Word ou editor de texto compatível, utilizando caracteres Times New Roman, tamanho 12 e espaçamento 1,5 justificado. As ilustrações - tabelas, quadros, gráficos etc. - deverão ser numeradas e trazer legendas. A fonte das ilustrações deverá ser sempre indicada.

7. Apresentar, em página separada: i) título do trabalho em português e inglês, em caixa alta e negrito; ii) até cinco palavras-chave; iii) resumo de até duzentas palavras, com a respectiva tradução para o inglês (abstract); iv) classificação JEL; e v) informações sobre o(s) autor(es): nome completo, instituição(ões) de vinculação, endereço e e-mail. Se o trabalho possuir mais de um autor, ordenar de acordo com a contribuição de cada um ao trabalho.

8. Caso o artigo possua gráficos, figuras e mapas, estes deverão ser entregues em arquivos específicos e editáveis, nos formatos originais e separados do texto, sendo apresentados com legendas e fontes completas.

9. As chamadas para as citações deverão ser feitas no sistema autor-data, de acordo com a norma NBR 10520 da Associação Brasileira de Normas Técnicas (ABNT).

10. Observar a norma NBR 6023 da ABNT, que fixa a ordem dos elementos das referências e estabelece convenções para transcrição e apresentação da informação originada do documento e/ou outras fontes de informação. As referências completas deverão ser reunidas no fim do texto, em ordem alfabética.

11. As submissões deverão ser feitas online pelo e-mail: bepi@ipea.gov.br

\section{ITENS DE VERIFICAÇÃO PARA SUBMISSÃO}

1. 0 texto ser inédito.

2. 0 texto estar de acordo com as normas da revista.

\section{DECLARAÇÃO DE DIREITO AUTORAL}

A submissão de artigo autoriza sua publicação e implica compromisso de que o mesmo material não esteja sendo submetido a outro periódico. 0 original é considerado definitivo, sendo que os artigos selecionados passam por revisão ortográfica e gramatical conforme o Manual do Editorial do Ipea ( $2^{\mathrm{a}}$ edição). A revista não paga direitos autorais aos autores dos artigos publicados. 0 detentor dos direitos autorais da revista, inclusive os de tradução, é o Ipea, com sede em Brasília. A tradução deve ser aprovada pelo editor antes da publicação. 
Composto em Adobe Garamond Pro 12 (texto) Frutiger 67 Bold Condensed (títulos, gráficos e tabelas) Rio de Janeiro-RJ 


\section{Missão do Ipea}

Aprimorar as políticas públicas essenciais ao desenvolvimento brasileiro por meio da produção e disseminação de conhecimentos e da assessoria ao Estado nas suas decisões estratégicas.

MECANISMO DA OCDE SOBRE CONDUTA EMPRESARIAL RESPONSÁVEL: EVIDÊNCIAS DO BRASIL E DE PAÍSES-MEMBROS DA OCDE E SUAS IMPLICAÇÕES

Edmundo Inácio Júnior

Cássio Garcia Ribeiro

IMPLEMENTAÇÃO DAS DIRETRIZES DA OCDE PARAAS EMPRESAS MULTINACIONAIS NO BRASIL: AVANÇOS E DESAFIOS

Hevellyn Albres

A COMUNICACÃO DO PCN BRASIL: COMO AS ESTRATÉGIAS E OS INSTRUMENTOS DE COMUNICAÇÃO PODEM CONTRIBUIR PARA O AUMENTO DA EFICÁCIA DAAGÊNCIA

Luíza Mônica Assis da Silva

UMAAVALIAÇÃO DA PARTICIPAÇÃO DO BRASIL NAS DIRETRIZES DA OCDE PARA CONDUTA RESPONSÁVEL DE EMPRESAS MULTINACIONAIS

Bernardo Mueller

Felipe Roviello

QUAIS CONTEÚDOS EMERGEM DAS INSTÂNCIAS ESPECÍFICAS RECEBIDAS PELO PCN BRASIL? REFLEXÕES A PARTIR DE ANÁLISES LEXICAIS

Luíza Mônica Assis da Silva

TRATADOS BILATERAIS DE INVESTIMENTO: CONCEITOS, POTENCIAIS IMPACTOS E TENDÊNCIAS FUTURAS

Ignácio Tavares de Araújo Júnior

O MODELO DE ACORDO DE COOPERAÇÃO E FACILITAÇÃO DE INVESTIMENTOS (ACFI) DO BRASIL E O REGIME INTERNACIONAL DE INVESTIMENTOS: OS CASOS

DE ANGOLA E MOÇAMBIQUE

Ana Garcia

Gabriel Torres

INVESTIMENTO EXTERNO DIRETO NAAMÉRICA LATINA: O PAPEL DOS ACORDOS DE INVESTIMENTO

Ignácio Tavares de Araújo Júnior

ACORDOS DE INVESTIMENTO E A DIFUSÃO DAS IDEIAS DE RESPONSABILIDADE SOCIAL CORPORATIVA: APONTAMENTOS CRÍTICOS A PARTIR DO MODELO BRASILEIRO

Marina Sanches Wünsch

Fábio Costa Morosini

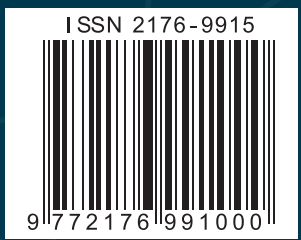

